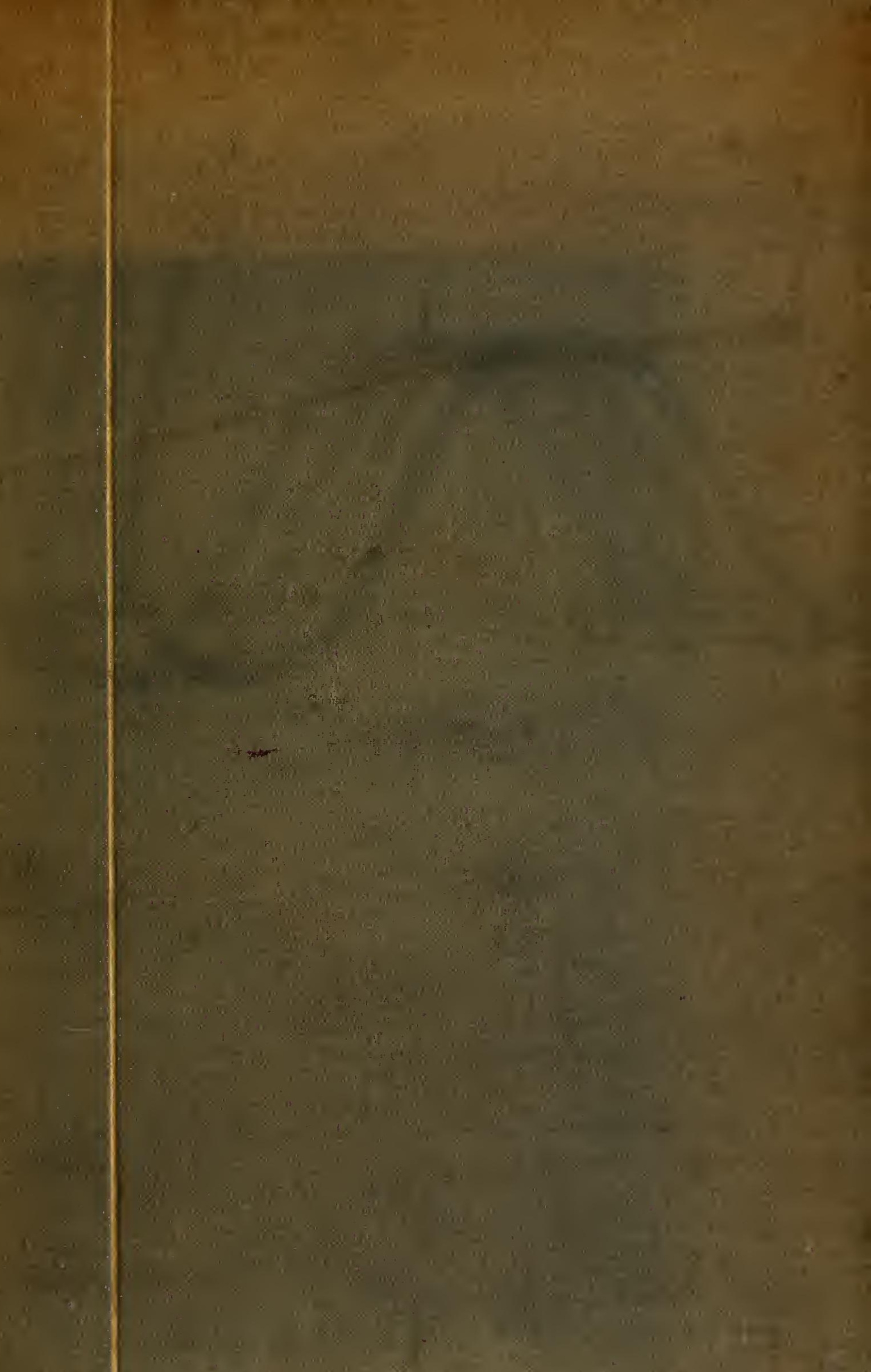



THE STRUCTURE AND FUNCTIONS

OF

BACTERIA 
HENRY FROWDE, MA.

PUBLISHER TO THE UNIVERSITY OF OXFORD

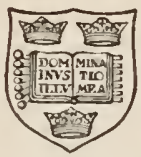

LONDON, EDINBURGH, AND NEW YORK 
THE

\title{
Structure and Functions \\ OF
}

\section{BACTER I A}

I3Y

\begin{abstract}
ALFRED FISCHER
PROFESSOR OF BOTANY AT THE UNIVERSITY OF LEIPZIG
\end{abstract}

TRANSLATED INTO ENGLISH BY

A. COPPEN JONES

\section{Oxford}

AT THE CLARENDON PRESS 
Oxford

PRINTED AT THE CLARENDON PRESS bY HORACE HART, M.A. PRINTER TO THE UNIVERSITY

10461 


\section{AUTHOR'S PREFACE}

SEEING that there is at the present time no lack of treatises upon bacteria, the publication of yet another needs some apology. Such an apology is expressed in the title, Lectures on Bacteria*. The lectures are intended to be an introduction to general bacteriology. They purpose to give a survey that shall collect and condense the innumerable special researches into a connected whole, and indicate in broad outlines the present position and extent of bacteriological science.

Besides those medical aspects of bacteriology which in other treatises occupy, rightly enough, the chief place, attention is drawn to the importance of bacteria in agriculture, and to the parts they play in the great fundamental processes of life-the circulation of nitrogen and carbon dioxide. Furthermore, it seemed desirable to point out and emphasize the advancement that general physiology has received from bacteriological investigations. Finally, an attempt has been made to remove the bacteria from the isolated position to which their morphological and physiological peculiarities had relegated them, and, by comparative studies, to indicate their relations to other organisms.

A treatment of the subject on these lines that should be at the same time not too bulky, seemed to me to be wanting. I therefore undertook the publication of the course of lectures I have delivered for some years to students of biology, pharmacy, and agriculture, with here and there among them-as it were like a white raven!-a medical student.

Alfred Fischer.

LEIPZIG, 22 July, 1897.

* The title of the German work is Vorlesungen uber Baklerien. 


\section{TRANSLATOR'S PREFACE}

IN offering to English readers a translation of Professor Alfred Fischer's Vorlesungen ïber Bakterien, an Introduction is rendered almost unnecessary, in the first place by the favourable reception of the original German edition, and secondly, by the fact that no work on Bacteriology of similar scope and mode of treatment has appeared in England since De Bary's classical Lectures on Bacteria. But those Lectures were published in $\mathbf{I} 887$, and the twelve years that have passed since then have been years teeming with activity in every field of bacteriological research. The present work epitomizes, in a comparatively small space, the results of these investigations, and attempts to elucidate them in their relations to the many-sided problems of Pathology, and of Technical and Agricultural Chemistry, and the great chemical processes of nature.

It should be stated that the few variations from the original that occur have been made with the Author's sanction, and that, furthermore, the book has enjoyed the advantage of a proofrevision by Professor Marshall Ward of Cambridge. The Index is the work of Dr. Alfred J. Ewart.
A. C. J.

Davos Platz,

March I3, 1900. 


\section{CONTENTS}

CHAPTER I

I $\mathrm{AGR}$

INTRODUCTION : MORYHOLOGY

Form, Size, and Structure of the Bacterial Cell, Cell-membrane and Cell-contents . . I

Morphology of the Bacterial Cell .

Finer Structure of the Bacterial Cell

\section{CHAPTER II \\ MoRPHology (continued)}

Pigments, Intracellular Products; Movement and Organs of Locomotion ; Cell-division; Sporeformation and Germination Movements and Organs of Locomotion

Reproduction of Bacteria by Fission

Spores and Sporulation

\section{CHAPTER III}

\section{TAXONOMY}

The Question of 'Species' among Bacteria; Variability; Involution and Attenuation; the Classification of Bacteria

\section{CHAPTER IV}

TaXoNomy (continued)

The Systematic Position of Bacteria; Other low Organisms with Pathogenic Properties

\section{CHAPTER V \\ Distribution AND ORIGIN}

Distribution of Bacteria; Their modes of life; Spontancous Generation .

CHAPTER VI

Physiology of Nutrition and General Principles of Culture

Chemical Composition of Bacteria

Food Stuffs of Bacteria .

\section{CHAPTER VII}

RESPiRATION OF BACTERIa

Aerobiosis and Anaerobiosis; Light-producing Bactcria; Marine Bacteria; Sulphur and Iron Bacteria

CHAPTER VIII

INFLUENCE OF Physical Agents

Light, Electricity; Pressure, Temperature, Dryness and Moisture; Disinfection by means of Physical Agents

CHAPTER IX 
Bacteria and the Circulation of Nitrogen in Nature

I. Introduction: The Assimilation of Free Nitrogen by the Bacteria of the Root Nodules of

Leguminous Plants, and by Bacteria in the Soil

\section{CHAPTER XI}

Bacteria and the Circulation of Nitrogen (contimued)

2. The Liberation of Organic Nitrogen by Putrefaction, and its Mineralization by the Nitrifying Bacteria

\section{CHAPTER XII}

The Circulation of Carbon Dioxide in Nature

1. Introduction; Organized Ferments and Enzymes; Races of Ferment Organisms; Fermentation of Alcohol and of Acids; Optical Activity and Fermentation

\section{CHAPTER XIII}

The. Circulation of Carbon Dioxide in Nature (contimed)

2. Bacterial Fermentation of Carbohydrates . . . . . . . . . . II6

Milk and other Dairy Products . . . . . . . . . . . II

Butyric Fermentation . . . . . . . . . . I I I

Cellulose Fermentation . . . . . . . . . . . . . I 22

Mucilaginous Fermentation . . . . . . . . . . . . I23

Fermentations in technical processes . . . . . . . . . . I 23

\section{CHAPTER XIV}

The Circulation of Carbon Dioxide in Nature (continued)

3. The Yeast Fungi and Alcoholic Fermentation. Theory of Fermentation and Anaerobiosis.

Concluding Remarks on the Circulation of Nitrogen and Carbon in Nature . . . 126

Theory of Fermentation and Putrefaction . . . . . . . . . . . I 33

\section{CHAPTER XV \\ BACTERIA IN RELATION TO DISEASE}

I. Diseases of Plants; Harmless 'Messmates' in the Human Body; Pathogenic Bacteria;

Points of Attack and Sources of Infection I 37

\section{CHAPTER XVI}

BACTERIA in RELATION TO DiSease (continued)

2. Description of sorre Pathogenic Species

\section{CHAPTER XVII}

Bacteria in Relation to Disease (continued)

3. Mode of Action of Racteria, and the Reaction of the Organism. Serum Therapeutics and Immunity 


\section{CHAPTER I}

\section{INTRODUCTION : MORPHOLOGY}

\section{Form, Size, and Structure of the Bacterial Cell, Cell-membrane, and Cell-contents.}

THE first historically recorded discovery of bacteria was made more than two hundred years ago by Anton van Leeuwenhoek, the Dutch naturalist and pioneer in the world of the infinitely littlc. Exploring those then untravelled regions with home-made lenses of wonderful efficacy, he found in the saliva of the human mouth minute organisms to which he gave the name of animalcula on account of their power of movement.

In the description ( 1 ) and in the figures he gives (reproduced in facsimile in Fig. I), curved and straight forms and long and short rods are plainly recognizable. They constitute the earliest reliable record of bacteria, the study of which in later times has revolutionized medicine and expanded into a new science. From the year 1683 Lceuwenhoek's observations stood alone until, a century later, the Danish savant Muiller made further investigations on bacteria. He classified them with the infusoria and gave them names that are now familiar

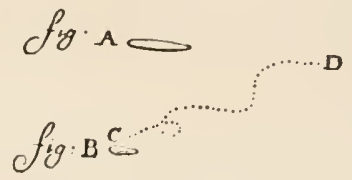
to us all, Vibrio, Spirillum, and Bacillus.

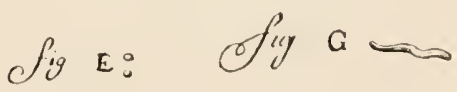
In 1838 Ehrenberg described in his great work on infusoria a large number of bacterial forms, ranking them with his group Vibrionia, and from this time forward the bacteria have never again clrifted entirely out of sight.

It was not, however, until about the seventh decade of this century that 
the subject was taken up by pathologists, who from that time to this have contributed more than any others to the building up of the science of bacteriology. It was after the publication of Robert Koch's (2) first studies on anthrax that the activity of those numerous investigators began, whose incessant industry has so furthered our knowledge of these most minute organisms and has accumulated a bulk of material such as the most voluminous treatises (3) are inadequate to grapple with.

Before this period of expansion and rapid growth, a growth that has been in some directions too luxuriant for strength or permanence, the bacteria had been studied chiefly by botanists (Cohn, Nägeli). Their work had been both physiological and structural, and it is on the foundations which they laid that the science in its modern form has been built up. For the fundamental labours of these earlier years, that saw, too, Pasteur's brilliant researches into the physiology of fermentation, the student may be referred to Löffler's lectures on the history of bacteriology (4).

\section{Morphology of the Bacterial Cell.}

The vegetative phase of all the smaller bacteria consists of a single cell. In the simplest types this has the shape of a sphere (coccus). If one diameter is greater than the other, i. e. if the sphere becomes a cylinder, it is spoken of as a rod or bacillus. In one group of cylindrical bacteria the cells are more or less spirally twisted (Vibrio, Spirillum, Spirochaete). In Vibrio (Fig. 2,c) the twisting comprises only a quarter of a revolution or less, in Spirillum (Fig. 2, a) one or more widely separated turns, while Spirochaete (Fig. 2,e) exhibits numerous closely-wound spirals like those of a corkscrew. The simplest method of permanently fixing the shapes of the bacteria is to let a small drop of water containing them dry upon a cover-glass. By this means they are all flattened to the plane of the glass, the vibrio, for instance, appearing, in spite of its three-dimensional curvature, only as a slightly curved 'comma'-shaped rod (Fig. 2, d). It was for this reason that Koch called the vibrio of Asiatic cholera the comma-bacillus, but as a matter of fact it has, apart from the curvature, no resemblance to a comma. A spirillum dries in the form of a semicircle (Fig. 2, $b$ ) and a spirochaete appears as a sinuous line (Figs. $2, c ; 26, f$ ). The spirochaetes often attain great length, but it is uncertain whether they then consist of a single cell or of a connected chain of several cells. The other types of bacteria-cocci, bacilli, vibrios, and spirilla-are always unicellular. They may be grouped together as Haplobacteria as contrasted with the many-celled true filamentous forms, the Trichobacteria. In the members of this group (in the sulphur-bacterium Beggiatoa (Fig. I 7, a), for instance) the vegetative phase is an unbranched chain or filament of closely united cells, each one having the shape of a bacillus and becoming free from the others and motile at the period of 
reproduction. The mbrancled filamentous bacteria without definite sheaths are generally classed together under the collective name of Lcptothrix. The most complex form is Cladothrin, an aquatic genus with numerous dichotomous branchings. Here the cell-chains are enclosed in a separate sheath and the latcral shoots arise by single cells pushing sideways through this envelope and growing out in a new direction. The resulting branch is thus only superficially connected with the parent stem (Figs. 2, $f ; 12$ ). This is spoken of as 'false branching' as contrasted with true branching, such as occurs in the mycelium of a fungus (Fig. $2, g$ ). $\ln$ this case one of the cells of the main stem sends out a lateral cvagination which, continuing to grow in the new direction, forms a branch. This new member is a lateral outgroweth of the parent cell itself, and as intimately comnected with the cells of the stem as they are with onc another. Among the trichobacteria this method of growth is unknown.

We have now cnumerated the various morphological types occurring among the bacteria, and there remain to be considered the aggregates and colonies which arise among the haplobacteria by the multiplication of the single cell or the proliferation of large numbers

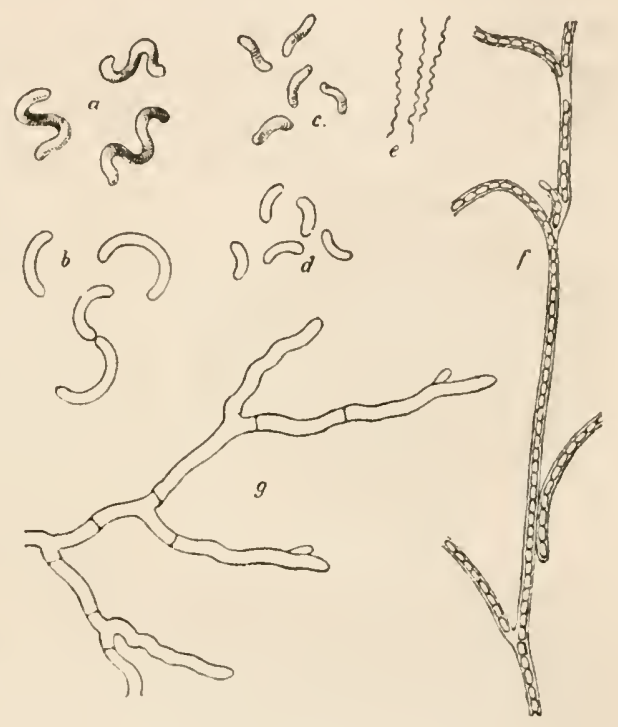

FIG. 2. a, Spirillum undula, living, with spiral twisting ; $b$, the saine dried on the cover glass in semicircular shapes. $c$, Vibrio cholerae, slightly spiral; $d$, dried in comma form. e, Spirochacle Obermaieri from the blood in recurrent fever. f. Cladothrix dichotoma, a branched example, with sheath and so-called 'false branching'; above $f$ a short branch of two cells is just pushing through the sheath. $g$, Penicillizm glaucum, a fragment of inycelium with true branching (from Brefeld). Amplification: $a$ and $b \quad 1500, c$ and $d$ $2250, e$ about $800, f 600, g$ i 20 . in close proximity. The Anthrax bacteria, for instance, often form unbranched threads or chains which are cxternally undistinguishable from those of the true trichobacteria (Fig. 28). Unlike these, however, the anthrax flament may at any time break up into its constituent cells irrespectirely of the advent of the reproductive process. Short threads of two or threc cells, as well as single cells, may also occur. These phenomena, both in bacilli and cocci, will be considered in more detail when the question of species is under discussion. Very frequently the bacterial cells are found collected in masses of more or less regular contour held together by a gelatinous substancc. To these masses the name of Zoogloea has been given. They occur both in liquids and on the surface of solid nutritive substances, such as potatoes or gelatine. Sometimes in liquids they form a skin or pellicle composed of very dense 
aggregates of individuals. In many cases the zooglocae and pellicles are merely social aggregates of individuals*, just as a forest or a meadow is, and, like these, cannot be considered as morphological units. In others, such as the cloud-like mass shown in Fig. 3 , or the delicate ramifying growth of $B$. proteus (Fig. 22), we have a true 'colony' before us, whose shape is not accidental, but a result of definite modes of growth and multiplication which recurs regularly in every culture, the characters thus produced being often of taxonomic value. In all such zooglocae and pellicles each single bacterium is independent of the others. The plant remains a single cell, and there is never any division of labour such as occurs in the more complex colonics of the lower plants (volvocincae) or animals (coelenterata).

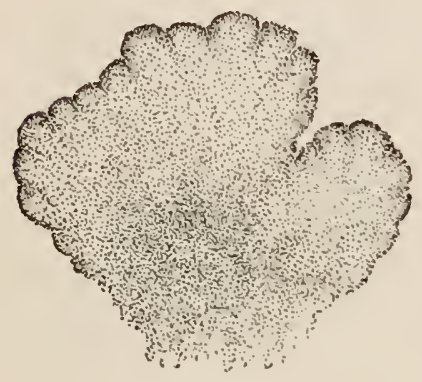

Fig. 3. Fragment of the botryoidal zoogloea of an aquatic bacterium ( $Z 00$ gloea ramigera) of older authors. The rods are thickly aggregated at the periphery, less so in the middle; they are held together by mucus. Magn. 56 . Compare the zoogloeae in Figs. 17, $e$, and $22, f$ and $h$.

to be increased eight million times before it attained the bulk of a middlingsized cigarette.

\section{Finer Structure of the Bacterial Cell (5).}

It would seem at first sight a hopeless task to attempt to gain an insight into the architecture of so minute a thing as a bacterium. Nevertheless the problem has been attacked, and, thanks to the efficacy of modern microscopes, some new facts have been established. We might well suppose that these organisms, standing as they do upon the very threshold of life, would be of simpler structure than those elementary units, the cells, of which all the higher plants and animals are built up. The first question then to be answered is whether all those parts which constitute a simple cell, such as a plant-cell,

* The word 'growth-form' is often applied to these aggregates. This literal translation of the German Wuchsform is an unfortunate one, inasmuch as the words growth and Wuchs do not connote precisely the same ideas, and, furthermore, the expression is used by different authors in slightly different senses (cf. Goebel, Outlines of Special Morphology of Plants, p. 480 ). 
can be clistinguished in the bacteria. The parts are: the cell-wall ( $w$, Fig. 4 , $a)$, the protoplasm ( $p$, Fig. $4, a$ ), the nucleus ( $k$, Fig. $4, a)$, and the cell-sap $(s$, Fig. $4, a)$. The cell-sap is contained either in spaces (vacuoles) scattered through the protoplasm, or in a large central cavity that fills out the greater part of the cell, the protoplasm being reduced to a thin layer coating the cell-wall (primordial utricle). Now the rclation of this protoplasmic lining of the cell to the cell-wall is of great importance in the study of the structure of bacterial cells, and it will be necessary to discuss in some detail the conditions present in the case of plant-cells in general. It will then be scen how far the observable facts are competent to elucidate the finer structure of bacteria. The cell-sap of vegetable cells consists of water in which are dissolved various substances, organic compounds and mincral salts. The protoplasm, which forms a sac enclosing the cell-sap, is during life endowed with propertics similar to those of animal membranes, being readily permeable to pure water, but almost or quite impermeable to the substances held in solution by the cell-sap. As a result, these bodies exert a strong pressure (osmotic pressure) from within outwards upon the protoplasmic sac, stretching it and pressing it tightly against the comparatively unyiclding cell-wall. An explanation of this is afforded by the modern Theory of Solutions which shows that the moleculcs of a substance dissolved in water act as though thcy were in a gaseous

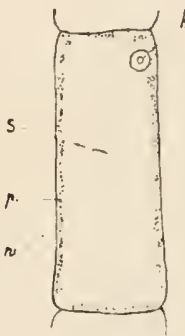

$a$
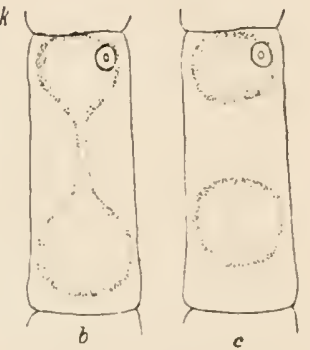

FIG. 4. Plasmolysis of a cell from a fine hair of Ecballium elaterium. a, distribution of the cell-contents in natural state (mounted in water): $z$, cell-wall; $p$, protoplasm (primordial utricle); $s$, cell-sap in central vacuole: $k$, nucleus. $b$, in $2.5 \%$ common salt solution, medium degree of plasıno. lysis; the protoplasm has retreated from the cell. wall and is being constricted into two parts. $c_{\text {, }}$ same cell after lying about half an hour in the $2.5 \% \mathrm{NaCl}$; the contents form two separate spherical masses. Magn. 300 . state and strive to fly outwards away from each other. Consequently, if the membranc is in the form of a closed sac surrounded by purc water and containing a solution, the substance dissolved behaves as a gas, and its molecules, like those of hot air in a bladder, expand and dilate the sac until the pressure inside is cqual to that without. In the case of the protoplasmic sac of plant-cells this condition of cquilibrium is unattainable, becausc unlimited dilatation is prevented by the cell-wall, and the result is that the whole of the cell is during life in a permanent condition of strain (turgor). It will be observed that osmotic pressure can only originate when there is water on both sides of the membrane, and this condition is present not only in waterplants, but also in terrestrial vegetation, inasmuch as the cell-walls are always saturated with water. If we now reverse the conditions and, instead of placing the cell in pure water, lay it in a solution of greater osmotic pressure than that of the cell-sap ( 5 per cert. saltpetre or 2.5 per cent. common salt) 
it is easy to foresee what will happen. The pressure on the outside of the protoplasmic sac being now greater than that within, the protoplasm is pressed inward away from the cell-wall. The sac shrinks until the concentration of the cell-sap is such that the osmotic pressure it exerts is just equal to that of the fluid outside. Since the shrinking of the protoplasm commences directly the pressure of the surrounding medium exceeds that of the cellsap, we have in this phenomenon, which is known as Plasmolysis, a means of measuring the pressure within the cell. The gist of the whole matter lies in the fact that the protoplasm is easily permeable to water both within and without, but presents a more or less impassable barrier to the molecules of the osmotic substances. As a result, the cells may lie for a long time in the plasmolysing solution without returning to their original state. If they be removed from the solution and placed in pure water again, the pressure of the molecules inside the protoplasm immediately reasserts itself, and the sac dilates until the original condition of turgescence is restored. All these phenomena are only observable in the living cell. At death the protoplasm loses its impermeability, and presents no hindrance to the molecules of substances in solution. In spherical cells the protoplasm is contracted by plasmolysis to a ball, but in long cylindrical cells, such as hairs for instance (Fig. 4), or algal cells, the elongated sac generally becomes constricted into two or three portions. These are at first connected by strands of protoplasm (Fig. 4, b), but finally separate and form distinct masses. The commonest case is where two round or oval lumps of protoplasm are left, one at each end of the cell (Fig. $4, c$ ). When, by transference to pure water, the process is arrested and reversed, these masses melt together again as soon as they touch and continuity is restored. This de-plasmolysation must not be too rapidly performed, or the fragments of the protoplasmic sac may burst, in which case the protoplasm invariably dies.

The application of plasmolysis to the study of bacterial cell-structure may now be discussed, but it will be advisable first to consider the results which other methods of investigation have yielded, notably those of fxing and staining. If we examine bacteria under a very high power objective (2,000 diams. and over) very little can be seen. The cell has a fairly sharp outline, but it is not possible to distinguish a separate membrane enclosing the cell-contents. The latter appears as a pale homogeneous mass with occasional granules of stronger refringency, and in the case of some of the larger bacteria (Spirillum, Cladothrix) sap-vacuoles differentiate themselves from the protoplasm by their watery appearance. These meagre details are all that can be seen in the fresh unprepared state,-of the organs of locomotion nothing can be seen,-but by the customary methods of fixing and staining a number of other particulars can be made visible. If a minute speck of a pure culture be mixed with a fixing fluid (e.g. osmic or chromic acid), spread upon a cover-glass, and allowed to dry, the bacteria adhere 
strongly to the glass and may by washing be freed from the fixative and stained with haematoxylin or an anilin dyc. Under this treatment all bacteria, save the most minute forms, show the same structurc (Fig. 5). The membranc appears as a sharp outline enclosing a protoplasmic mass which is smooth and homogeneous where it lines the imembranc, but full of irregular spaces (vacuoles) towards the centre. The protoplasm is uniformly stained and shows no trace of fincr details. Only the strongly refracting gramules already referred to take on a deeper tingc. Being similar in this respect to the 'chromatic substance' of cell-nuclei, they are sometimes spoken of as 'chromatin' granules : a doubtful analogy at best. When the bacterial cell contains only onc such granulc (Fig. 5, $a, c, d, e$ ) it certainly makes the impression of a nuclcus both as regards its size and its position in the ccll. But there are, just as often as not, screral granulcs in a single cell (Fig. $5, b, d, f$ ), and apart from the colour-rcaction we have no adequate reason for regarding them as nuclci. They bear no relation to the process of celldivision, and it is better to regard them merely as granules of reserve food-stuff. All cfforts to detect a true nucleus have as yet failed, and it is safer at present to look upon the bacterial cell as being deroid of one. There is however another view of the matter that has gained many adherents. When bacteria are stained with anilin colours they appear to take up more of the stain than does the protoplasm of ordinary plant-cells, and to retain it with greater tenacity in the face of decolourizing reagents such as alcohol and weak acids. Since moreover the

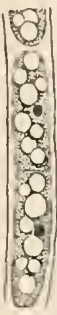
a
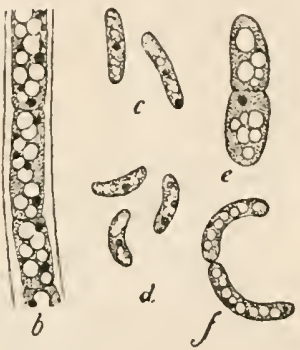

FIG. 5. Bacteria fixed with alcoholic iodine solution and stained in various ways. $a$ and $b$, Cladothrix dichotoma with sheath and one $(a)$ or several (b) chromatin granules in each cell (haematoxylin). $c$, Typhoid hacteria (methylene blue). d, Vibrio cholerae (methyleneblue). $f$, Spirillum undula (haematoxylin). All the figures show the cell-structure described in the text. Chromatin granules, black; vacuoles (sap-vacuoles), white; protoplasm, stippled. Mlagn. $a-c 2250, f 1500$. nuclei of all cells are distinguished by their avidity for colouring matters there has arisen the idea of a certain group of substances, melear stains, that possess a peculiar affinity to nuclear substance. This affinity is mythical. Nuclei take up all stains with more avidity than the protoplasin does, and this behaviour rests probably not on the chemical nature of the nucleus but on its physical constitution, such as its great density and power of absorption. It is to the failure to recognize these facts that the statement must be attributed which we meet with in almost all books on bactcriology, namely, that the bacteria have a particular affinity to 'nuclear' stains' and that we are thercfore justificd in regarding them as primitive nuclei devoid or almost devoid of protoplasm. Spcculation followed speculation, and, the bactcria being the simplest organisms known to us, the hypothesis has been put forward that the frrst living things to arise on the carth were similar naked nuclei, and that the protoplasm is the product of subscquent 
evolution. The tingibility of the cell-contents in bacteria is not so great when one takes into consideration the amount of stain taken up by the cellmembrane, and even though in some cases an unusual amount may be absorbed there is certainly nothing that warrants us in assuming the existence of a specific reaction between the anilin stains and nuclei. The bacterial cell then, interpreted in the light of the above facts, is a simple protoplast enclosed within a cell-membrane but devoid of a nucleus.

The phenomena of plasmolysis lend additional strength to this view. To plasmolyse bacteria it is only necessary to place upon a slide a drop of water containing bacteria, lay upon it a cover-glass (with a few fibres of cotton-wool between to prevent crushing), and

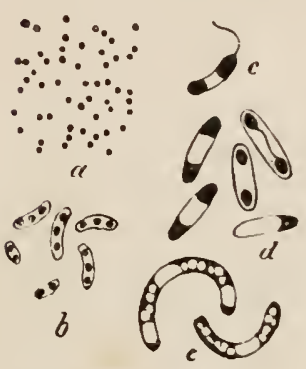

Fig. 6. Plasinolysis of bacteria. a, Vibrio cholerae from an agar culture (Bouillon $+1 \%$ peptone $+1 \%$ grape sugar) in $1.25 \% \mathrm{NaCl}$. They are plasmolysed but still living; the protoplasm is broken up into refrin. gent granules. $b$, The same more highly magnified. c, Vibrio cho. lerae plasmolysed with ciliun. $d$, Typhoid bacilli in $2.5 \% \mathrm{NaCl}$, stained; cell-contents in various positions, to the right a cell with the protoplasm arranged as in the plant cell (Fig.,$+ b) . e$, Spiril. lum undula plasmolysed by the evaporation of stagnant water the structure of the clumps of protoplasm is well seen. Protoplasm black in all figures. Magn. a 300, b-e 1500. allow the plasmolysing fluid to run in at the edge. Spherical and very short rod-shaped bacteria become under this treatment more highly refractive. This increase of density is the outward expression of the contracting of the cell-contents, and in these very minute forms it is the only change perceptible. In the larger bacteria, however, such as typhoid, cholera, spirillum, cladothrix, \&c., the details of the process are readily followed. Solutions of 2.5 per cent. saltpetre or I per cent. common salt (fresh blood serum contains 0.7 per cent. $\mathrm{NaCl}$ ) are sufficient to set up plasmolysis. As soon as the solution reaches the bacteria its effect is visible, and one sees the protoplasm gradually raised away from the cell-wall and pushed inward. Just as in elongated plant-cells, it frequently breaks up into two or three highly refractive rounded masses which expand and fuse together again if the plasmolysing solution be replaced by pure water (Figs. 4 and 6). In short rods the protoplasm generally contracts to a single spherical or egg-shaped mass which lies sometimes in the centre of the cell, sometimes at one end. With a low amplification plasmolysed bacteria often look as though they had broken up into a row of granules (Fig. 6, a), but careful examination under a high power reveals the delicate membrane of the cell-wall still intact (Fig. 6, b). Two facts of fundamental importance are brought to light by these phenomena. They show in the first place that the protoplasm of the bacterial cell is not, as is the case with the 'pellicula' of infusoria, attached to the cell-wall, but lies free within it just as does the protoplasm of plant-cells, and furthermore that the osmotic pressure in the bacterial cell is comparatively low, only about half that of the cells of higher plants which need solutions twice as strong to plasmolyse them. The pressure inside the bac- 
terial cell is nevertheless considerable, namely from two to threc atmospheres. In stronger solutions (5 per cent. saltpetre) the plasmolysis is rapid but ceases in a few minutes, and the protoplasm expands and fills out the cell again. This retrogression of the process is caused by the penetration of the molecules of the salt. Even in weak solutions $(2.5$ per cent. saltpetre) this takes place in a few hours, showing that the protoplasm of bacteria is far more easily permeable than that of the higher plants, a peculiarity which is shared by other low organisms such as flagellata, cyanophyceac, and florideac. A most important result of this greater permeability is the ease with which bacteria are able to adapt themselves to changes of concentration in the medium they live in, and it must greatly facilitate the absorption of foodstuffs as well as the excretion of the products of metabolism such as toxins and enzyms. Finally, it must be mentioned that the motile forms retain their power of movement during plasmolysis, from which fact certain conclusions can be drawn as to the nature of the organs of locomotion.

In the usual methods of preparation the liquids in which bacteria are suspended contain a considerable amount of soluble salts (the ordinary nutritive media hold 0.7 per cent. $\mathrm{NaCl}$ ), and when a diop evaporates upon the cover-glass the liquid becomes more and more concentrated, so that before the bacteria become dry they are plasmolysed. It is such plasmolysed cells which we see in most cover-glass preparations, many species such as B. typhi, Vibrio cholerac, and Spirillum undula frequently showing strongly stained granules (Polar-granules) at each end of the cell, the central space being empty (Fig. 6). The meaning of these appearances is evident. The general conclusion to which all these observations lead us is that the bacterial cell-contents are a mass of protoplasm representing an osmotic system precisely like that of the cells of the higher plants, but, unlike them, having no nucleus.

The membrane or cell-wall of the bacteria is in most cases thin, delicate, colourless, and without a perceptible finer structure. Unlike the cell-wall of plants, it consists of a protein substance (no doubt a modification of the protoplasm) and not of ccllulose*. It would secm therefore that the degree of division of labour which characterizes the higher plants, where there is an outer very permeable membrane of cellulose, and an inner more or less impermeable protoplasmic layer, has not been reached by the bacteria where communication between the organism and the outer world is regulated by two layers of medium permeability.

As is the case in many algae and cyanophyceac, the cell-wall of some bacteria secietes a jelly-like substance which appears optically as a delicate

* Analysis of the cell-wall of the $B$. tulcrculosis shows that it contains a large amount of true ccllulose, so large indeed that it has been detected in tuberculous animal tissues, and was thought to be a product of metabolism (Freund). 
clear space, sometimes narrower, sometimes broader than the cell it surrounds (Fig. 7, $c$ and $d$ ). It may be rendered more visible by special methods of staining. It owes its origin to the swelling up of the outer layers of the cell-wall by absorption of water, the inner layers being constantly built up anew from within. This gelatinized membrane may become more and more liquefied until large numbers of cells are buried up in a common jelly-like mass, and it is in this way that the various forms of zoogloea arise. The majority of bacteria have no such envelope at all, or at most a thin invisible mucilaginous coat. The formation is often largely, dependent upon the nature of the food-stuffs available (Fig. $7, b$ and $c$ ). Inasmuch as many bacteria secrete large quantities of mucilage without forming a definite envelope, the word 'capsule' should be sparingly used and restricted to clearly marked sheaths around the cell. Only in such cases has it any classificatory value (Lenconostoc). Moreover, the clear

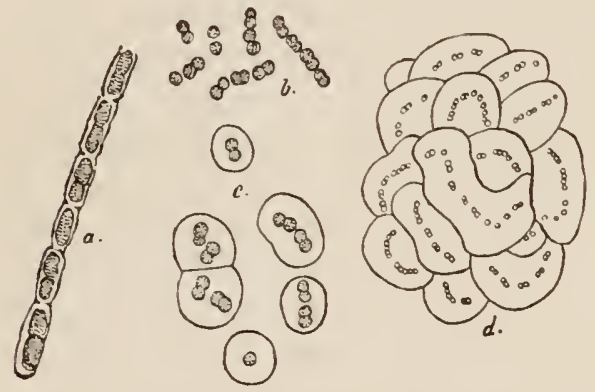

Fig. 7. Capsules and mucous sheaths. $a$, Bac. anthraciswith so-called capsules in a dried streak-preparation from the liver of a inouse; for the nature of these and of the capsules of other pathogenic bacteria, see p. jo. $b-d$, Leuconostoc mesenteroides (frog spawn fungus); $b$, on non-saccharine media, without sheath; $c$, with mucous sheath on medium containing sugar ( $b-c$ from Liesenberg and $Z$ opf $; d$, older zoogloea mass with chains of cells (from van Tieghem). Magn. $a{ }_{1500,} b$ and $c 1_{200} d 500$. spaces visible around bacteria in dried preparations are frequently artificial products. These are particularly prone to arise in fluids like blood and lymph, which contain albuminous substances, the albumen being secmingly precipitated upon the bacteria, around which it forms a coating that easily takes up stain. When drying takes place the cells, being the last to give up their moisture, shrink away from this envelope and each one appears to be surrounded by a capsule (Fig. $7, a$ ). That this is, however, nothing but an artificial structure is shown by the fact that the same bacteria which in the blood of an animal exhibit a capsule are, with some doubtful exceptions, both in the tissues and in cultures, quite devoid of one. In a mouse which has died of anthrax, the bacteria in the blood seem to have a capsule (Fig. 7, a), whilst those in sections of the kidney are totally devoid of one. That this is not due to a difference of the modes of growth in the blood and in the tissues is shown by the fact that the naked anthrax bacilli from an agar culture become provided with an apparent 'capsule' if they are rubbed up with a drop of blood from a healthy mouse and allowed to dry upon a cover-glass.

Among the trichobacteria (Cladothrix, Crenothrix) and some of the cyanophyceae (Tolypothrix, Lyngbya), the outer layers of the cell-wall undergo a hardening process which leads to the production of a firm sheath 
enclosing the cylindrical cells in such a way that they are frecly movable within (Figs. 2, and 5). At the period of reproduction the cells, themselves devoid of sheaths, become furnished with cilia, and, escaping from the open end of the sheath, swim away and give rise to fresh colonies. In this way whole forests of cladothrix are emptied of their cells and there remain only the stiff sheaths which finally swell up and become disintegrated. Occasionally the sheaths become fossilized as it were, by the deposition upon them of oxide of iron. They are then very resistant to decay, and accumulate sometimes in enormous quantitics in chalybeate springs and ferruginous marsh water (see Chap. VII). The term 'sheath' can only be applied when a distinct tube is formed in which the chain of cells are enclosed; colourless spaces in stained preparations of filamentous bacteria do not necessarily imply the existence of a sheath, being often the result of plasmolysis. 


\section{CHAPTER II}

\section{MORPHOLOGY - continued}

\section{Pigments, Intracellular Products; Movement and Organs of Locomo- tion; Cell-division; Spore-formation and Germination.}

MOST bacteria are individually colourless, and appear, even when massed together in a pure culture, either white or of a ycllowish tinge. There are, however, a considerable number of species, the chromegcnic or pigment-bacteria, remarkable for the brilliant colouration of their cultures. Some of the Sarcinae, for instance, have a bright yellow tint, Staphylococcus pyogcuus aurcus is golden ycllow or orange, $B$. brunucus ycllowish brown, Micrococcus agilis, Bacillus prodigiosus, and Spirillum rubrum each a different shade of red, $B$. cyanogenus (the bacillus of blue milk) bluc, $B$. violaccus a deep violet; and many kinds of water-bacteria, as well as the bacillus of blue pus, give origin to brightly fluorescent pigments. The production of all these colouring matters is very variable and largely dependent upon the conditions of growth, upon the composition and reaction of the culture media, and upon the influence of oxygen, light, and heat.

Most pigment-bacteria appcar under the microscope to be colourless, and the question at once suggests itself whether the colouring matter is really contained within the cell. In $B$. prodigiosus, the cause of the 'blceding host,' the pigment can be scen in the form of granules scattered about between the colourless bacteria, so that in this case there can be no doubt as to the seat of the colour of the cultures. The various fluorescent substances also are secretions of the bacteria with which they are associated, and they diffuse into the culture medium, which often fluoresces brightly throughout its whole thickness. The pigment of B. cyanogcmus also is dissolved in the culture medium. In most pigment-bacteria similar conditions prevail, that is to say, they are 'chromoparous' (6). Some species, on the other hand, are actually 'chromophorous,' i. e. the protoplasm itself is coloured. This is the case with the sulphur bacteria Chromatium and Thiocystis, and with some sap-green species (B. vireus). As regards these last, however, it is undecided whether they are bacteria or minute algae ( 7$)$. 
Finally, there are bacteria, $B$. aiolacens for example, in which the pigment is lodged mainly in the cell-wall; such forms may be termed "parachromatopluorous.'

There is conclusive evidence that the red colouring matter of the sulphur bacteria, 'bacteriopurpurin,' performs the same functions as the chlorophyll of higher plants, assimilating carbonic dioxide under the influence of light and giving off free oxygen (sce Chap. VII). Only the outer layer of the cell contents is charged with pigment, the central mass being colourless.

In all probability the colouring matter is of importance physiologically only where it is bound up with the protoplasm. In all the 'chromoparous' bacteria the pigment is an excretion merely, and, as might have been expected, chemical and spectroscopic analysis fail to show that it has any connexion with assimilation.

Some of the bacterial pigments are of the nature of lipochromes and are related to the fats; others have a basic character and resemble the ptomaines. Many seem to belong to the proteins, and the colouring matter of $B$. cyaneo-fuscus has a composition similar to that of indigo.

Differentiated cell-contents, such as the starch or aleurone grains of higher plants, are wanting in most bacteria. The protoplasm stains a uniform golden yellow when treated with iodine. Some of the butyric acid bacteria, however, as well as various species inhabiting the human mouth, form an exception to this rule, and take on a blue or deep violet tint. Very little is known about the substance to which this reaction (granulose reaction) is due; it has bcen called granulose merely on the strength of its behaviour towards iodine. Whether its chemical composition is similar to that of the granulose of starch cannot be decided by this reaction alone. It seems to be a carbohydrate, however, and carbohydrates as food are necessary for its growth. The mouth bacteria obtain these of course from our food, and the butyric acid organisms from the fermenting substances in which they grow. The 'granulose' makes its appearance in the bacterial cell in the form of very minute grains, so that after treatment with iodine the yellow protoplasm seems full of black points. These granules become considerably larger, and then seem to diffuse through the cell contents, so that finally the whole cell stains blue or violet.

In the butyric acid bacteria granulose is at first absent, but is formed when the time of sporulation draws near. In that part of the bacterium, however, where the spore appears, none is deposited, the protoplasm staining from first to last yellow with iodine. It would seem that we have here an instance of division of labour, the swollen end of the bacterial cell being devoted to sporulation, and the cylindrical portion serving as a manufactory and storchouse for granulose, from which the spore may be nourished (Fig. I $1, c-f$ ). 
Absolutely unique in the whole of organic creation is the case of those bacteria whose protoplasm contains free sulphur (Chap. VII). In these 'sulphur-bacteria' the cell is often crammed full of highly refracting globules, which are soluble in alcohol, xylol, bisulphide of carbon, and alkalies, and give other reactions of pure sulphur. It is in a non-crystalline, soft, amorphous state, and when dissolved out by carbon disulphide leaves delicate clear vacuoles in the protoplasm. Deposits of other substances within the bacterial cell have not as yet been observed, with the exception of fat or oil, which sometimes appear in the form of minute globules, particularly in old cultures.

\section{Movements and Organs of Locomotion.}

All bacteria, whether spontaneously mobile or not, are, when suspended in water, in constant motion. Examined under a high power, they are seen to be shaken by a rapid oscillatory movement. This, the so-called Brownian movement (8), is in no sense a vital phenomenon, but is common to all finelydivided solid particles suspended in liquids. It may be observed in the particles of gamboge or indian ink rubbed up with a little water. Its cause is not well understood. As a general rule there is no danger of mistaking the trembling motion for the spontancous movements of bacteria.

There are two kinds of independent motion distinguishable among bacteria - the ordinary swimming movement, and the rarer 'oscillation ' peculiar to some trichobacteria and similar to the movements of some cyanophyceae. Among the cocci, Micrococcus agilis is the only one endowed with the locomotory powers, but of the bacilli a large number are actively mobile, such as $B$. typhi, the butyric bacteria, and the majority of the putrefactive organisms. The vibriones and spirilla, too, are good swimmers. The bacilli of tuberculosis, diphtheria, anthrax, many of the pigment bacteria, and the acetic and lactic ferments are permanently immobile. When bacteria in active movement are examined under a high power they seem to shoot across the field of view with amazing speed; but this velocity is only apparent, being due to the magnification of the distances they cover. Reduced to actual figures, the absolute rate of progress is $10 \mathrm{~cm}$. in 15 minutes, or about $\frac{1}{9} \mathrm{~mm}$. per second-in proportion to their size a very fair speed.

Locomotion is effected by special organs, the cilia or flagella. In the fresh state, or in bacteria stained in the ordinary way with anilin colours, the cilia are not visible, and special methods of preparation are necessary to render them so. That worked out by Loeffler (9) has the claim to priority and is the best. He employs in the first place a mordant composed of an iron salt and tannin, which causes the stain to be thrown down not only within the cell, but also upon its surface and upon the surface of the cilia, which 
then appear deeply coloured. Both bacteria and their cilia are by this process made to look thicker than they really are, and appear therefore more clearly.

According to the arrangement of the cilia upon the cell the bacteria may be divided into three groups-monotricha, lophotricha, and peritricha (10). The members of the first division bear a single flagellum at one end of the cell (Figs. 8, $a$, and 23); examples are the cholera germ and other vibrios, and B. pyocyanens. The lophotrichous bacteria have in place of the single flagellum a brush or tuft of cilia (Spirillum, many putrefactive bacteria; Figs. $8, b ; 22, a ; 12$ ) and the peritrichous forms have their whole surface beset with cilia more or less thickly arranged, so that they appear almost as though they had a shaggy coat $(B$. typhi, B. coli commmis, some butyric ferments, $B$. subtilis, $B$. protcus, and many others; Figs. $8, c, e$, and II, 13, 22, 24, 28). The arrangement of the cilia is constant in each species, and even the number of cilia united to form the terminal tuft has a taxonomic valuc.

Functionally and structurally the cilia of bacteria correspond to the analogous - organs in other groups, such as the swarm-spores of algae and fungi, the infusoria, and the ciliated cells of metazoa. They consist of long delicate threads of protoplasmatic substance, which vibrate to and fro and propel the bacterium through the water as a boat is propelled by oars. They grow out slowly from the body of the cell (Fig. 8, d), and are not retractile. The shrinkage of the cell-

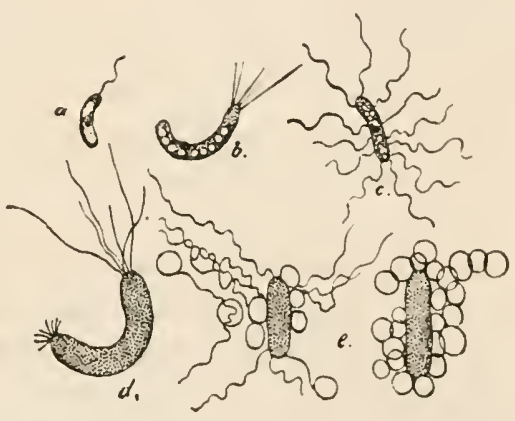

Fig. 8. Types of ciliation. $a$, monotriclous (l'ibrio cholerae); b, lophatrichous'(Spirillumwndula); $c$, peritrichous (typloid bacilli); $d$, development during fission of the cilia tuft of Spirillum undula; $\varepsilon_{1}$ partial and (to the right) complete looping of the cilia in Bac. subtilis. Magn, a-e 2250. In Figs. $a, b, c$, the structure of the cell-contents has been taken from iodine preparations (Fig. 5) in order to illustrate the structure of bac. teria as far as is known at the present time. In Figs: $d$ and $e$ the contents are schematically shaded, for in these preparations (stained by Loefler's method) the piecipitation of colour on the cellsurface conceals the structure. See also Figs. 11, $12,13,17,22,23,24,26$ and 28 , which give further examples of various ciliation. contents during plasmolysis leaves the cilia unaffected, so that they would scem to be fairly inclependent organs. They receive their nourishment and vis viva from the protoplasm, with which they are connected through minute pores in the cell-wall.

The cilia are very sensitive to injury, unfavourable conditions causing them to be thrown off. When shed in this way they sometimes become disintegrated and disappear in a few minutes. As a result a preparation made from a culture containing actively mobile bacteria frequently shows not a single cilium, and this is particularly the case when old cultures are employed, the bactcria they contain being especially sensitive. Not infrequently the cilia become rolled up or looped before they are shed, and 
peritrichous bacteria then appear to be surrounded by a mass of bubbles (Fig. 8, $e$ ).

The speed of movement of the bacteria is subject to great variations, the cilia being often paralyzed by noxious physiological conditions. Lack of oxygen, insufficient nutriment, and the accumulation of acid in old cultures are all factors which bring about this paralysis, and it is only necessary to remove them (by neutralization of the acid, by removing the cover-glass, by the addition of sugar, asparagin, \&c.) to at once restore movement to the cilia. That bacteria are motionless is not therefore a proof that they belong to a non-motile species, and in some cases much experience is necessary for decision.

The linear progression of bacteria through a liquid is always accompanied by a rotation around the longer axis of the cell, as is the case with the swarm-spores of the lower thallophytes. In the flagellate infusoria the end of the cell bearing the flagellum is always in advance in swimming, and probably the lophotrichous and monotrichous bacteria move in the same way, a reversal of the path necessitating a revolution of $180^{\circ}$ around the transverse axis of the cell. The peritrichous bacteria have a similar mode of progression to that of the members of the other groups, but in addition they often exhibit curious tumbling movements, the cell hurrying across the field of view and turning somersaults the whole way.

In Beggiatoa, one of the filamentous bacteria, remarkable slow oscillatory movements of the threads are observed, isolated fragments of which are also able to glide to and fro as diatoms do. Both these types of movement occur too among the cyanophyceae, giving the name to one group of forms, the Oscillariae. The cause of the phenomena is quite incomprehensible, no organs of locomotion having been discovered, and the cell-wall being apparently closed all round, so that the protoplasm cannot be perceptibly extruded anywhere. It is, however, highly improbable that the motion is independent of the protoplasm. More delicate methods of research will perhaps enable us to clear up the mystery.

The term flexile has been applied to filaments which, although per se rigid and stiff, are not straight, but twisted and thrown into curves. It is supposed that such flexile filaments have somewhat less rigid cell-walls, which yield to the strain exerted on them by the cell contents. These flexile threads occur in all trichobacteria, but in the haplobacteria the membrane is always rigid. Kinks and twists in filaments seem to arise frequently by the mechanical displacement of neighbouring cells. The subject of flexility needs further investigation.

\section{Reproduction of Bacteria by Fission (11).}

Given suitable conditions of nourishment, bacterial cells, like those of all other organisms, divide into two when they reach a certain size. In 
the filaments of the trichobacteria cell-division means growth and increase of length of the filament, and the process can only be called multiplication when a cell detaches itself from its fellows and grows out into a new filament. Among the unicellular haplobacteria, however, each cell-division means duplication of the individual. The procedure follows the same course as it does in the tissues of the higher plants. The cell first increases in length, and then becomes divided into two by a transverse wall. The spherical bacteria (cocci) assume an cllipsoidal figure before dividing, and the two new cells are at first flattened where they are in contact, rounding off to perfect spheres again as they separate. Of the finer details of the process nothing has becn scen among the bacteria, nor anything resembling those clianges in the arrangement of the cell-contents which characterize cell-division in the higher organisms. The protoplasm is simply abstricted into two parts separated by the ingrowing cell-wall, as in Cladophora. In the filaments of this alga celldivision is ushered in by the deposition of a ring of cellulose on the inner surface of the cell-wall, where the new partition is to arise (Fig. 9, a). By constant addition to its inner cdge this ring grows broader, until at last, cutting through the protoplasm, it stretches right across the lumen of the cell and divides it into two equal parts. There scems little
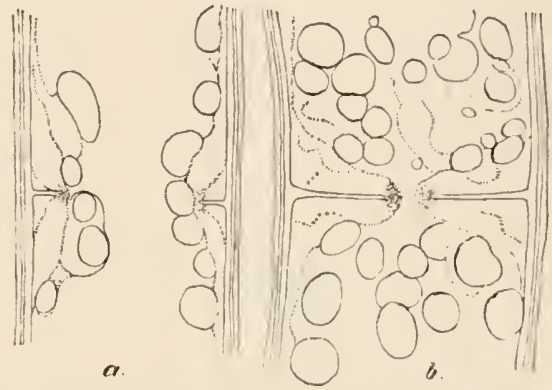

FIG. 9. Transverse division of a multinuclear living cell of an alga (Cladophora fracta). The new cellwall (as in all multinuclear cells) arises independently of the division of the nuclei. In Fig. $a$ the new transverse cell-membrane grows out as a ring at right angles to the sides of the cell and appears (in optical section) as rod-like outgrowths from the latter, the free ends being surrounded by gramular potoplasm. The large round bodies are starch grains. Fig. $b$ represents an older stage, the new menlbrane is complete with the exception of a sinall spot in the centre. The figure is meant to give an idea of what probably takes place during the fission of bacteria which are too minute to allow the process to be followed. From Strasburger. Magn. 600.

doubt that division of the bacterial cell takes place in the same way, but the details of the process are too minute even for our best microscopes to follow.

Under the most favourable conditions of temperature and nutrition celldivision takes place in a very short time. B. subtilis, the 'hay-bacillus,' completes the process in half an hour. The cholcra vibrio necds only twenty minutes, so that in one day a single 'comma-bacillus' would rejoice in a progeny of sixtecn hundred trillions. This mass of bacteria would contain one hmodred tons of solid residne, and it would thus be necessary to make experiments on a gigantic scale to allow even one single cell to multiply with perfect frecdom. In nature, of course, this increase in geometrical progression can never take place: in the first place, because the necessary supply of food is never present, not even in the discased body, and then again because many of the bacteria soon perish, and the accumulation 
of the excreta (bacterial products such as acids, \&c.), particularly in pure cultures, arrests development. As standards of comparison it may be mentioned that a complete division of nucleus and cell in the staminal hairs in Tradescantia takes from eighty to one hundred minutes, and that the process may be effected in Amoeba in from ten to twenty minutes. The rate of multiplication among the bacteria is therefore nothing extraordinary, particularly when we consider the simple structure of their cells and the absence of a complicated karyokinetic process.

When a cylindrical bacterium divides into two it is immaterial, as far as the result is concerned, whether the division is longitudinal or transverse; but, as a matter of fact, we find that it is always transverse, be the cylinder straight or spirally twisted. This is in harmony with the generally observed law in cell-division, that the new membrane is always formed in the most economical manner; that is to say, in such a way that a minimum of material is required. In cylindrical cells this is manifestly the transversal position. When the cells resulting from such division remain connected, chains and filaments arise, particularly in the case of non-motile species. They occur sometimes even among motile forms, such as the cholera vibrio (Fig. 28, $k$ ), although in this case the moving cells are more easily separated. Inasmuch as transverse fission is the only mode of increase among cylindrical bacteria, it follows that chains or filaments are the only kinds of colony or 'growth-form' that can occur, save where there is a subsequent shifting of single cells (as in Cladothrix).

In the monotrichous and lophotrichous bacteria it is always the nonciliated end of the dividing cell which bears the cilia for the new individual (Fig. 8, d), the inner ends of the two rods never bearing them. In all cases where the cell seems to have cilia at both poles there are in reality two young cells still united by their inner ends. A curious possibility arises out of this fact. At every division it is only one individual that is provided with new cilia, the other cell bearing the old ones, and this process may be repeated time after time. As a result, it may happen that of two bacteria swimming about and not as yet disconnected one has brand-new cilia, and the other a set which has lived through hundreds of generations.

In peritrichous forms it seems probable that, during the elongation of the cell preparatory to fission, new cilia arise between the old ones along the side of the cell.

Among the spherical bacteria it is manifestly, as far as the economy of the cell is concerned, a matter of indifference in which direction the plane of fission lies, because every plane that passes through the centre of the cell represents a minimum. A predilection for one particular plane must therefore be the outward expression of hereditary morphological characters that possess a classificatory value. The closest resemblance to the cylindrical bacteria is shown by those spherical forms in which the planes of fission of 
successive gencrations are all parallel. In this case, if the cells remain attached to each other, unbranched chains arise as in Strcptococcus pyogenes (Fig. 10, a), a pus bacterium, or as in Lenconostoc mescntcroides (Fig. 7, d). If fission takes place alternately in two directions at right angles to one another, flat tabular groups of cocci are produced, frequently quadrangular, with four, sixtcen, sixty-four cells and so forth. The red sulphur-coccus Thiopcdia and Micrococcus (Pediococcus) tetragenus (Fig. 10) are cxamples of this mode of growth. Finally, the planes of division may be formed in three different directions successively, at right angles to cach other, giving origin, when the cells remain adherent, to cubical packets. The genus Sarcina (Fig. 10, c) offers a typical instance of these. It is, of course, possible to determine the manner of fission among cocci only when the cells remain adherent to each other, or where successive generations are held together by gelatinous cxudations. If the cells scparate after fission their grouping gives no indication of the manner of division.

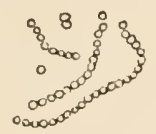

a.

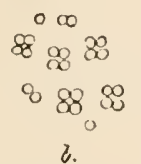

¿.
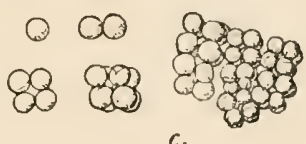

c.

Fig. I0. Modes of fission among the coccaceae. $a$, Sircplococcus pyogenes, planes of fission always parallel, resulting in chains; $b$. Pediococcus telragenus (Micrococcus tetragenus), lission alternately at right angles in tuo planes, resulting in plate-like growths; $c$, Sarcina lutca, fission in three planes at right angles to each other, resulting in cule's or bale:shaped growths.

There remains yet another mode of increase conceivabie, in which the planes of division arise without definite sequence or relation to previous planes. This would result in all manner of irregular cell-groups, above all in ramifications in one or more planes; but there are no observations that would prove the cxistence of such, and we can only conclude that irregular fission does not take place. It seems likely that even in the great host of micrococci (e.g. the Staphylococci of the pathologists) the splitting up of the cells follows a fixed rule, but that their prompt severance from one another prevents the formation of large groups. As far as the Staphylococci are concerned, division probably occurs in the three dimensions alternately, but not in regular sequence, so that after a few fissions in one plane a new direction is taken at right angles to it, to be changed again soon for a third. In this way we should get short chains, quadrate groups, and minute cubical clusters side by side, and this is what actually occurs (Fig. $2 \delta, a$ ).

\section{Spores and Sporulation (1:2).}

The bacterial cell, although able for a short time to resist the injurious effect of an unfavourable environment (drought, changes of temperature) or an insufficient food supply, cannot defy such influences for an unlimited 
period, for months or years. It has, however, the ability to enter into a resting stage, to assume a shape endowed with great powers of resistancethe 'spore.' This power it shares with all low organisms such as algae or fungi, which are periodically subject to dearth of nutriment or the inclemency of the seasons. The term 'spore' is commonly applied to all these resting forms, but must not be supposed to connote anything but a similarity of function. The word 'endospore' has in addition a special morphological significance, and is applied to the commonest form of bacterial spores. Taking the sporulation of the anthrax bacillus as a type, we find the process begins by a contraction of the cell-contents, which ball themselves together into an egg-shaped mass as yet devoid of a proper membrane, and lying loose in the otherwise empty rodlet: this is the young spore

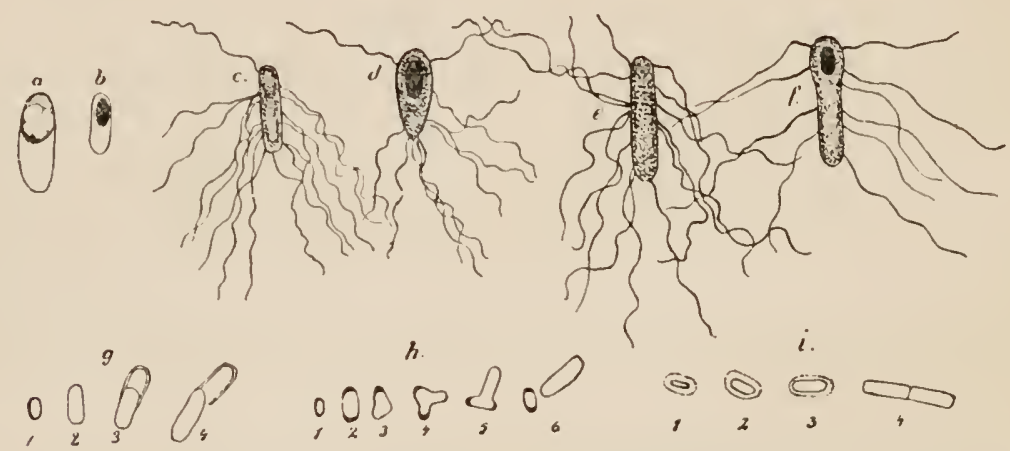

FIG. I1. Sporulation and germination. a, Anthrax bacillus with the cell-contents contracted to form the young spore, as vet without membrane; $b$, ripe anthrax spore still enclosed in the rod, whose shape has not changed. $c$ and $d$, Clostridium butyricum (Prazm.) : $c$, vegetative peritrichous stage; $d$, ripe spore in the swollen spindle-shaped cell, the contents of which are not quite used up in spore-formation. $c$ and $f$, Plectridium paludosum: $e$, unchanged rod; $f$, drum-stick or talpole form with ripe spore in swollen end. $g$, Germination of spore in $B$. anthracis; the young rod elongates itself in a direction parallel to the longer axis of the ellipsoidal spore $(3,4)($ from Prazmowski). $h$, Germination of spore of $B$. subtilis; the new rod grows out at right angles to the axis of the spore $(3-5)$, and, as in anthrax, separates from the spore membrane (6) (from Prazmowski). i $B$. leptosporus; the spore, surrounded by a thin mucous coat (dotted $\mathbf{I}-3$ ), grows out into a rod without shedding a membrane; simplest form of germination (from Klein). Magn. $a$ 2250, $b-f$ about $1200, g-i 1000$.

(Fig. I I, a). This contracts still further, becoming denser and more highly refractive than when it filled out the cell, and there forms upon its surface a firm coat, the proper sporc-membrane, to the impermeability of which the durability and resistance of the spore are due. The spore lies now complete within the cell-wall (Fig. I I, b), which gradually decays and sets it frec. The free spore, which may be found abundantly in cultures two to three days old, is a highly refracting, cllipsoidal, immobile body, considerably smaller than the cell in which it arose. Under favourable conditions of tempcrature it germinates in twenty-four to thirty-six hours. Rags of the cell-membrane may often be seen still adhering to it (Fig. II, $g, h, i$ ). The spores of B. subtilis are formed in a like manner, the rods, as in B. anthracis, retaining their cylindrical shape during the process (Figs. I I, b; I 3, c). A less simple type of sporulation is that where the rods change their shape, becoming 
spindle-shaped (Fig. 11, $c, d$ ), or swollen at one end like a drum-stick $($ Fig. $11, c, f)$. The greater part of the cell-contents is withdrawn into this inflated portion, and forms the spore, but some remains in the cylindrical section of the cell, where it can be rendered visible by plasmolysis as an extremely delicate layer lining the membranc. It is no doubt from this remnant of protoplasm that the cilia derive their nourishment at the time of sporulation; for they are not drawn in during the process, but continue to lash vigorously to and fro until the spore is set free and nothing but the empty cell remains. The spindle-shaped butyric bacilli and the drum-stick cells of some bacteria in bog-water form their spores in this manner, and it secms that in all cases where the spore-bearing part of the cell alters its shape some of the protoplasm remains in the cylindrical section.

It is certain, in spite of many contradictory statements, that the alteration in shape has the value of a specific character, and can be used for classificatory purposes. The significance of the process lics, of course, not in the change of shape, but in the differentiation of the cell-contents into two parts, one for the maintenance of life in the cell, the other subservient to reproduction. It is a forcshadowing of that division of labour which secures the distribution of spores and their transport to places suitable for germination.

Endospores are still unknown in a large number of bacteria-in the whole group of cocci, for instance, and in many pathogenic forms, such as the bacteria of typhoid fever, tuberculosis, diphtheria, and cholera. That they do form spores there can be no doubt, but our artificial methods of culture do not offer them the necessary conditions, the determination of which is one of the important tasks that bacteriology has before it. In the pathogenic bacteria mentioned, as well as in many other forms, highly refracting granules have been described as spores, but proof is wanting; they have not been secn to germinate. It is certain that in a number of cases what have been taken for spores are merely 'chromatin-granules' and plasmolysed lumps of protoplasm in disintegrated or decaying cells.

Ordinary methods of staining leave the spores untinged, and they appear, so long as they remain within the body of the cell, as clear colourless spaces. It must be remarked, however, that we are not for this reason justificd in regarding all clear spaces in stained bacteria as spores. Many methods have been claborated for obtaining beautiful double staining of the spores within the rods, the impermeability of the spores being overcome by boiling them in the staining solution, or by submitting them to the action of substances like chromic acid, which render the spore-membrane more penetrable, either by causing it to swell up, or more probably by dissolving out certain constituents. The question whether any given structure is a spore cannot, however, be decided merely by its colour reaction-germination is the only reliable proof. 
As soon as the spores are ripe they are capable of germination, and in a dried state remain so for many years. This property is not peculiar to the spores of bacteria : well-dried wheat germinates after being kept for twenty years, and the spores of the smut-fungus may lie in a herbarium for eight years and not lose their vitality (see Chap. VIII). Moistening with pure water is not sufficient to cause germination of bacterial spores. A solution capable of setting up a nutritive stimulus is necessary, and, of course, a suitable temperature.

The first stage of germination is the slow swelling up of the spore, which gradually becomes less and less refractive (Fig. II, $g 2, l$ 2, i 3). In $B$. subtilis this phase lasts from one to three hours. Then the sporemembrane bursts open at one point, and the contents, surrounded by a delicate cell-wall, are protruded, and elongating soon assume the form of a rod, the new bacillus (Fig. $11, / / 2-6$ ). The end of this often bears for a long time the ragged remnants of the spore-membrane. Germination is now complete, the whole process having taken about four or five hours. One peculiarity connected therewith is worthy of remark. The spores of B. subtilis are in shape short ellipsoids, having the longer axis parallel to the longer axis of the cell that gave them birth. The new rod, on germination, bursts through the side of the sporc, and stretches itself at right angles to the latter (Fig. I,$h 5$ ), so that the longer axis of the new generation crosses that of the old. The spores of $B$. anthracis and of Clostridium butyricum, on the other hand, burst open at the end, so that the axes of the new and old generation are continuous. Both these types of germination are common among bacteria, but they are constant for the same species, and therefore can be used for purposes of classification.

The simplest germinative process is that shown by some harmless saprophytic bacteria (e.g. B. leptosporus), where the spore itself grows out without casting its membrane into the new bacillus (Fig. II, $i$ ). In this case the unchanged spore-membrane becomes the cell-wall of the young rod, whereas in B. anthracis, B. subtilis, and Clostridium butyricum the coat of the spore splits into two layers-an outer, which is left as the empty membrane, and an inner, which ensheathes the protruding contents of the spore and becomes the cell-wall of the new-born bacterium. The spores of many fungi also germinate in this way.

De Bary (13) has described, under the name of arthrospores, structures which have given rise to a great deal of misunderstanding. He gave this name to certain cells in filamentous bacteria, such as Cladothrix (Fig. 12), Thiothrix, \&c., which detach themselves from their fellows and swim about after the manner of swarm-spores, finally growing out into filaments again. They are certainly reproductive cells (Gonidia), and may perhaps be termed spores, in so far as a spore is subservient to reproduction. De Bary called them artlerospores because they are formed from one joint or cell in the 
cell-chain, but they possess none of the essential properties of a spore. They are simply detached vegetative cells without special powers of resistance and destitute of any lasting germinative faculty. Another kind of arthrospore is said to occur in the case of Lenconostoc, where certain cells gencrally larger than their neighbours surround themselves with a very thick membrane, and without further preparation enter the 'resting stage.' Similar cases occur among the bluc-green algac, but are quite unknown among ordinary bacteria. What have been described as arthrospores in bacteria (in cholera cultures, for instance) are in all probability nothing but decplystaining granules from the detritus of old cultures. They have never been seen to germinate. Bacterial arthrospores, if the term were justified, would be of the same shape as the vegetative cells of the species to which they belonged; the cholera arthrospore appearing as a curved refringent rod, that of $B$. violaccus as a straight cylinder, \&c.

Of the causes which bring about sporulation very little can be said. As with other organisms, it seems to be induced by an unfavourable environment, arrest of food supply, or the accumulation of the excretory products of the bacteria themselves. In pathogenic forms, at least in those cases that have been carefully studicd, spores are not produced so long as the bacteria are enclosed within the discased tissues. The anthrax bacillus forms them only in places where there is free access of air-in the excretions of diseased cattle, for instance, or on the surface of the carcase; never inside it, cither before or after death (sce also Chap. XVI). 


\title{
CHAPTER III
}

\author{
TAXONOMY
}

'The Question of 'Species' among Bacteria; Variability; Involution and Attenuation; the Classification of Bacteria.

DESPITE the morphological sameness of the bacteria, the functions they perform in the economy of nature are numberless. When their extraordinary versatility first became known, the idea arose that they were beyond the influence of many of the laws of life which govern all other organisms. Any opinion regarding bacteria, however absurd it might be, was permitted, and even the existence of definite species among the bacteria was denied. The controversy on the species question has been long and heated, and only in the last few years has it been decided once for all that the conceptions of genera and species are as justifiable among the bacteria as among other organisms. The subject-matter of the whole discussion may be summed up in two words: pleogeny or mutability of function, and plcomorphism or mutability of shape (14). The pleomorphists maintained that a coccus did not necessarily remain a coccus all its life long, that it could, under certain conditions, stretch itself and assume the shape of a bacillus, that this again could become curved and change into a vibrio, to return again later on to the coccus form that it commenced with. Words like Micrococcus, Bacillus, Vibrio, Spirillum, which we now know to have a definite taxonomic value, were in the eyes of the pleomorphists worthless designations of transient changes of shape.

As an example of almost inexhaustible versatility the branched aquatic bacterium Cladothrix dichotoma was advanced. But it has now been proved to be not truly pleomorphic (15). Only at the season of reproduction, for the purpose of securing new fields of growth, does the cell undergo change. It loosens itself from its fellows in a filament, develops a tuft of cilia, and emerges from the sheath (Fig. I2). The bacillus-like gonidia or swarmspores thus produced settle down sooner or later upon some solid body, to which they adherc, and then grow out into new filaments. Neither coccus, 
vibrio, nor spirillum forms appear. The various twistings and distortions of filaments, and aggregations of motionless gonidia, which have been described as phases of pleomorphic development, are quite fortuitous.

Pus-cocci (Staphylococci) may be cultivated in any number of different media, but they appear with unalterable persistence in the form of little spheres (Fig. 28, a). The cholera vibrio occurs in the form of a slightly curved rod, and it occurs in this form only. The only observable variation in growth is that in some cultures isolated cells may prevail, and in others chains (Fig. 28, k). In a hay-infusion culture of B. subtilis, for instance, we meet side by side motile and motionless single cells (Fig. I $3, a, b$ ), and, especially in the surface pellicles, motile and motionless chains (Fig. 13, b). In all these the individual bacterium remains unchanged, a unicellular, peritrichous-ciliate, actively motile rod (Fig. I 3, a). The motionless rods arise from any causes which bring about temporary paralysis of the cilia, and the motile chains from the clinging together of successive generations of cells. In a fresh culture the fluid is uniformly turbid, with actively moving isolated rods only. These are afterwards driven by lack of oxygen to the surface of the culture, where they grow out into long, motionless, sporc-bearing chains devoid of cilia, the aggregation of which forms a membrane or pellicle on the surface of the liquid. This completes the cycle of forms.

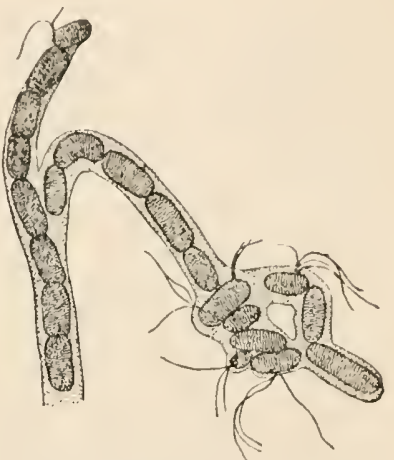

FIG. 12. Cladothrix dichotoma. formation of swarm spores. The sheath (stippled) of the left lranch has opened and gives exit to a swarm spore; in the right branch a whole group of cells has changed into swarm sporcs, each with a lateral tuft of cilia. On this side too the sheath is swollen up, loosened. Magn. 1000.

These instances will suffice to show that pleomorphism in its true sense does not exist. In all the simple bacteria (haplo-bacteria) the 'growth-form' only changes. Single cells unite to chains, clusters, or zoogloea, according to the substratum they live in, but the form of the individual of the vegetative cell remains the same.

That proper and improper nutriment must have a great effect upon the size of the cell is evident. Giant and dwarf forms occur among the bacteria as among all other organisms, and have the same significance. But for all species of bacteria there is an average size and form, deviations from which are not more extensive than they are among other organisms: always assuming that the conditions of existence are suitable, that the bacteria are in a healthy condition, which is far less frequently the case than we are apt to think. Imagine a few thousand animals cooped up together in a confined space, plentifully supplied with food, but without provision for the removal of their dejecta. A few hours would suffice to bring about a frightful state of things. And these are just the conditions under which 
the bacteria are living in agar cultures, in all our culture media in fact. In such circumstances it is no wonder if some of the cells grow into misshapen, feeble involution forms, with their physiological functions, such as virulence or fermentative power, weakened or suppressed (16).

Bacteria, like all other living things, produce crippled and deformed individuals when forced to live under unsuitable conditions (Fig. 14). These abnormal bacterial cells are known as 'involution forms.' The causes of involution are of various kinds. Acetic bacteria, for instance (Fig. I4, $c-d$ ), produce monstrositics if their own fermentation product (acetic acid) accumulates beyond a certain point, and also if the temperature cxceeds the

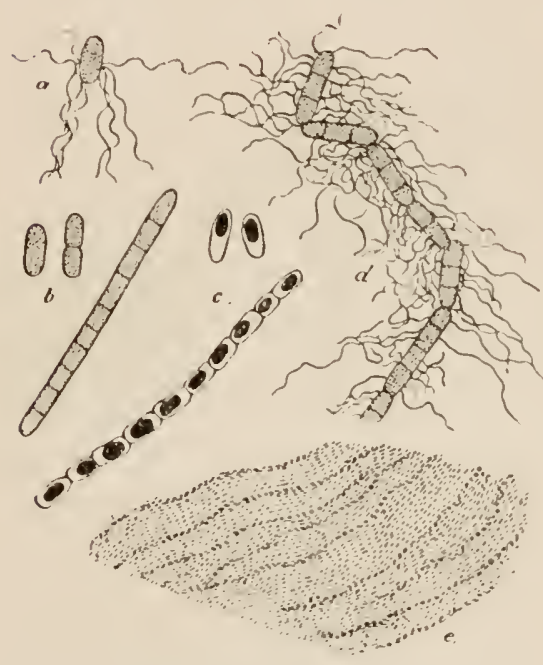

FIG. 13. Bacillus sublitis in hay infusion. The figure shows the coinplete cycle of forms. $a$, Peritrichous motile short rod; $b$, non-motile rods and chains : $\boldsymbol{d}$, motile chains; $c$, spores in non-motile rods and chains that unite on the surface of the infusion to form a thick whitish pellicle $e$. Magn. $a-d{ }_{1500} e$ (from Brefeld) 250.

rently all that is left in the cell. optimum. In $B$. subtilis involution forms arise if the relative proportions of nitrogen and carbon in the culture medium are not suitable-a solution of 0.1 per cent. asparagin and to per cent. sugar, for instance. In other cases a high percentage of neutral salts induces them. A curious case of involution is that shown by the bacteria in the root tubercles of the leguminosae (see Chap. X).

The shapes that the cells assume are very varied. Irregular, swollen, or spindle-shaped rods and twisted chains are common, and the protrusion of short lateral processes from the cells often gives the growths the appearance of a branched system (Fig. I4). At the same time the cell-contents are reduced and stain badly, a few granules being appaCells which show a high degree of involution are dead, and cannot, even in the most favourable conditions, be revived. They are common in old cultures, and particularly so in those of strictly parasitic forms, such as the diphtheria and tubercle bacilli, that even in the most nourishing media do not find quite the conditions they require.

Such branched involution forms have been thought by some to show that the bacteria of diphtheria and tubercle (Fig. I4, $l, g$ ) are fungi of a higher order of growth than their ordinary rod form would indicate. It has been suggested that the rods are merely a stage in the development of a true filamentous bacterium or even a hyphomycete, and new names have accordingly been given to the organisms, the tubercle bacteria being placed 
in a new genus Mfycohactorium or Tuberculonyecs, and the diphtheria parasite in another, Corynchacterium. In the writer's opinion such an alteration is not justified, for the branched forms of tubercle bacillus that arise in three to six months old colonies are by no means common, and agree closely in appearance with the involution forms in the root-nodules of leguminosae Fig. $14, c-f$, and of the acetic bacteria $\mathrm{Fig}$. $\mathrm{J} 4, c-d$.

If the influences which give rise to involution forms be restrained within certain limits, a general weakening or attenuation of the bacteria is

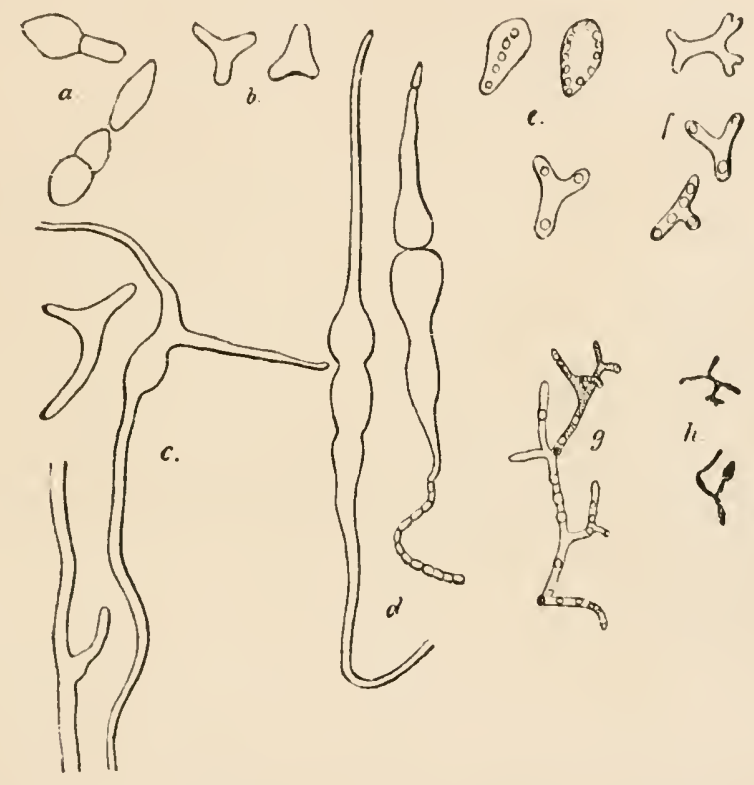

FiG. 14. Involution forms. a, Rac. subtilis from a four-dars old culture containing $1 \%$ sal ammoniac, $2 \%$ grape sugar, and $0: 5 \%$ nutritive salts (weakly acid). $b$, Typloid-like bacilli from water in ltay infusion with $4 \%$ sal ammoniac; they are non-motile, without cilia, and suggestive of the bacteria of root-nodules $(e$ and $f)$. $c_{1} B a c$. tcrium aceti at $39^{\circ}-41^{\circ}$ (from E. Chr. Hansen). $d$, Bacterium Pasteurianum, 7 hours at $34^{\circ}$ (from Hansen). $e, B a c-$ teroids from the root-nodules of Vicia villosa; the round spots are the still retainable remnants of cell-contents (from Morck). $f$, Bacteroids from Lupinus albus (from Morck; the four-armed one is from Vicia villosa). $g$, Tubercle bacillus, branched filament from sputum (from Coppen Jones). $h$, Diphtheria bacilli, so-called branched forms ; they are certainly involution forms (from Bernheim and Folger). Magn. $a$ and $b \mathbf{5 0 0 ,} c$ and $d$ soo, $e$ and $f$ about $15(x), g 1250, h$ about 100 .

effected. This condition arises spontancously in long-continued cultivation on artificial media ; virulence, fermentative power, and other functions being diminished. They may be revived again, however, if the process has stopped short of involution, by restoring the bacteria to a more natural environment: in the pathogenic species by repeated passage through the animal body, in the ferment organisms by giving them renewed opportunity for active fermentation.

The attenuation induced by prolonged artificial culture can be secured in a much shorter time by exposure to more noxious agencies. The most important form of enfecblement, the loss of infectious power, can be induced 
by almost all operations injurious to life, if only the proper degree of strength be chosen. Anthrax bacilli are attenuated by a few hours' exposure to direct sunlight or by the addition to the culture media of $\mathrm{O} \cdot \mathrm{I}-$ 0.2 per cent. phenol. Trichloride of iodine is effectual in the case of the diphtheria and tetanus bacilli. By careful exposure to high temperatures, Pastcur was able to produce a less virulent breed of anthrax bacilli which retained their acquired characters for a long time (17). The change effected was the same whether the cultures were maintained at $42.5^{\circ} \mathrm{C}$. for twentyeight days, at $43^{\circ}$ for six days, at $47^{\circ}$ for four hours, or at $52^{\circ}$ for fifteen minutes. The temperature optimum for Bac. anthracis is between $30^{\circ}$ and $37^{\circ}$, the maximum about $42^{\circ}$ or $43^{\circ}$, and the lethal limit lies between $50^{\circ}$ and $60^{\circ}$, so that it is evident that attenuation is effected the more quickly the nearer the temperature approaches the lethal limit.

That the decrease of virulence is only one phase of a general weakening of all the functions is shown by the fact that the bacteria in attenuated cultures have lost the power of forming spores: have become asporogcnous (18). At first sight this seems to be a result of the greatest importance. Spore formation is one of the principal morphological features of the cell. If we were really able to suppress it, and to suppress it so successfully that it never made its reappearance even in the most vigorous cultures, we should indecd have done a great thing, for we should have obtained nothing less than the long desired proof of the hereditary transmission of acquired characters. But appearances, alas, are deceptive. It is no more possible to obtain in this way a breed of sporcless anthrax bacilli than it is to rear a tailless race of mice by incessantly cutting off their tails. All we do is to hinder the production of fully ripe, resistant spores : rudimentary spores are formed. We attain nothing more than a general enfeeblement of the cell affecting all its functions equally. This is proved by the fact that such 'attenuated' and 'sporeless' cultures get weaker and weaker and finally die. By the inoculation of the weakened bacteria into suitable animals and several passages through the body, in short, by a bracing treatment, virulence is restored and resistant, fully ripe spores appear again. The micro-organisms behave, in fact, just as sickly plants do when removed to healthy surroundings. The importance of the experimental modification of virulence for the attainment of artificial immunity will be considered in a later chapter.

All these considerations show us that external agencies (in the brief period which our experiments allow) are unable to bring about a lasting, hereditary change in the structure of bacteria. The morphological characters remain constant. The variety always throws back to the typical form, the conception of species and genera having the same value among bacteria as among the higher organisms. Billroth's views, according to which all the bacteria occurring in an infected wound were different developmental stages of the 
same species (Coccobactiria septica), can be no longer held. Like \%opf's far-reaching speculations on the cycle of forms among bacteria, they are matters of history, and they are nothing more. The similar ideas of Niggeli have been unable to hold out in the face of more recent discoveries, and there can be no doubt that the justification of Cohn's original conception of the possible systematic classification of the bacteria is now generally recognized.

Less simple to decide than the question of pleomorphism is the question of physiological change or pleogcny*. All bacteria possess to a certain extent the power of living on different kinds of substrata, and the composition of these determines in a great measure the nature of the chemical changes which the bacteria set up. According to the degree to which this power is developed, we may conveniently divide the bacteria into two classes, the monotrophic and the polytrophic. Among the members of the first group the requirements of nutrition are specific and clearly defined. The composition of the substrata may vary only within very narrow limits, and, as a result, the metabolic products also of these bacteria and the functions they are able to perform are specific and well defined. As typical examples of the monotrophic group may be mentioned the sulphur bacteria, the nitrifying organisms, all the truly parasitic bacteria, and those found in the root-nodules of the leguminosac. Among the great host of ferments and putrefactive organisms, too, there are monotrophic forms with specific properties. Such are the bacteria of the acetic, lactic, and some butyric fermentations, and the bacteria which decompose urine (urea ferment). Some of the butyric bacteria, on the other hand, are polytrophic, and, besides possessing specific fermentative powers, are ablc to break up albuminous compounds; they are saprogenic as well as zymogenic. Others of the same class are pathogenic also, and can live in the tissues of the animal body (malignant ocdema, quarter evil). We find, too, forms like B. anlgaris with pronounced saprogenic (putrefactive) powers, which are yet able to grow on non-putrefactive substances and cause them to ferment.

Again, many saprophytic bacteria are unable to exist in the animal body, while others (typhoid, cholera) are decidedly polytrophic in this respect, and multiply rapidly in the tissues. It is not necessary to give parallel examples of differences among other organisms.

As might be expected, it is in monotrophic forms that the 'specific characters,' both morphological and functional, are most sharply marked. But they undergo no lasting change even in those bacteria which are physiologically the most versatile; and the attainment in our cultures of new varicties, varieties with acquired characters that are permancnt and hereditary, is not to be expected. We are able, it is true, to obtain cultures of

* Detailed instances will be found in Chaps. V, XI, XII, XIII, and XV. 
pathogenic species with every desirable gradation of virulence, but they are not new varieties. They are mere laboratory stocks, which revert at once to the original type as soon as the original conditions of life are restored*. It has not been hitherto possible to entirely suppress a single biological character in any species. The supposed conversion of the anthrax bacillus into the harmless $B$. subtilis was never realized, and, like most reports of a similar character, arose from imperfection in the technique of pure culture.

Although there is no longer any doubt that the various kinds of bacteria constitute definite species and genera, it would be futile to minimise the great difficulty that confronts us as soon as we try to arrange them in a system of classification. The morphological similarity of the spherical forms (cocci) and the close resemblance to each other of the rod-shaped bacilli make a classification based on purely morphological data quite impossible. Physiological characters have therefore been made use of as auxiliaries-for instance: growth on various media and need for oxygen or particular forms of nourishment; specific products such as pigments, granulose, sulphur, fluorescence, phosphorescence ; specific chemical changes such as fermentation, putrefaction, disease. A reliable description of the species of bacteria is a task for the future, and will only be attained by the united labours of pathologists, physiologists, chemists, and botanists (19). Much has been done by arranging them in groups according to their most prominent physiological characters. Examples of such groups are the saprogenic or putrefactive, the zymogenic or fermentative, the chromogenic or pigment-producing, the phosphorescent, the thermogenic, the nitrifying, the iron bacteria, and the sulphur and purple bacteria. Such a classification is not without value, but it is not justifiable to make generic names on this principle, and use them as though the groups they indicate were equivalent to true morphological genera. Such names as Photobacterium, Nitrobacter, Nitrosomonas, Granulobacter (for butyric bacteria with the granulose reaction), Halibacterium (for marine forms), Gonococcus, and Proteus (for several putrefactive bacteria) are names that should not be admitted in a systematic classification. As working or trivial names they are useful enough, but have no claim to equality with genera based on morphological characters, which must, after all, form the ground-work of all systems of classification. An attempt must be made, despite the dearth of material, to obtain clear morphological definitions of the genera at least, even if it be impossible at present for species. This was Cohn's guiding principle (20), and must be adhered to. The very factor to which the progress of bacteriology is mainly due, namely the number and variety of its students, has been a hindrance to the proper growth of a classification. Side by

* The various 'races' of brewery yeasts have a different value to these 'attenuated' bacteria. 
side with the medically trained 'bacteriologist,' to whom the principles and meaning of classification were unfamiliar, there have been investigators from every other branch of biology-brewers, agriculturists, and even chemists, all vying with each other in the manufacture of species. It is not argued for a moment that botanists alone have the right to set up a system; but it cannot be too often repeated that other investigators, if their taxonomic schemes are to be of any value, must proceed on the recognized and established principles of classification. As things are, there is no agreement even as to the value to be attached to the few clearly marked morphological features which do exist. The only point of unanimity is the adoption of Cohn's groups founded on the shape of the cell (coccus, rod, spiral, or filament). The importance of the distinction between filamentous bacteria and those forms which consist of a single cell descrves more emphasis than it usually receives. The filamentous bacteria, trichobacteria, constitute an order, separate from the haplobactcria, in which the colonies of cells are mere 'growth-forms' or social aggregates of individuals, such as, for example, the packets of Sarcinac, or the cobweb-like zoogloea of $B$. vulgaris.

The power of movement or its absence has very properly been regarded as a distinctive feature, but the constancy of the ciliation (mono-, lopho-, peritrichous) has been undervalued. A cholera vibrio or a bacillus pyocyaneus has only one flagellum (as a rare exception two); the typhoid bacillus, B. subtilis, and many others are always peritrichous. Lophotrichous forms like the spirilla and other aquatic bacteria, or the bacillus of blue milk (B. syncyaneus), always have a polar tuft of cilia, the number of which is approximately known and fairly constant. That their numbers in a staincd preparation are often irregular is due to the delicacy of the structures, which are casily thrown off, and not to any original irregularity. In the motile bacteria, as in the flagellate infusoria, the number and arrangement of the cilia are morphological characters of fundamental systematic value. Another is the form of the sporulating rod, which, although described by some as variable, possesses in reality the constancy required of systematic characters. The anthrax bacillus retains its cylindrical shape, the tetanus bacillus becomes invariably swollen at one end, like a drum-stick (plectron), and some of the butyric bacteria assume the shape of a spindle at the time of sporeformation. Exceptions to the rule are generally deformed individuals, and are very rare, not one in a hundred. A careful discrimination of these two characters, ciliation and sporulation, cnables us to arrange the chaotic multitude of rod-shaped bacteria into a few well-defined genera and sub-gencra. It may be argued that in many cases the spores are unknown. This is true, but it is no reason why we should not classify the better known forms into ' good' genera, relegating the others provisionally, according to the shape of their cilia, to genera where the sporulation is unaccompanied by change 
of shape in the rod. The names of the genera might be formed conveniently in such a way that the root of the word indicated the shape of the cell, and the termination the arrangement of the cilia. The root-words might be baktron (rod), kloster (spindle), and plectron (drum-stick), and the terminations -inium for monotrichous, -illum for lophotrichous, and -idium for peritrichous types. The classification of the less numerous spirilla is, as the table shows, a simpler matter. Among the Coccaceae the manner of cell-division has already been employed as a generic character, but greater weight should be attached to the contrast between two more comprehensive groups into which they naturally fall. These are the Homoccocaceae, where the planes of fission follow a definite sequence, and the Allococcaceae, in which such regularity is not found (see pp. 18 and 19).

The different meanings attached to the words Bacillus and Bacterium deserve notice. In two of the most recent systems of classification (21) the senses in which they are used have little in common. Lehmann and Neumann apply the word Bacterium to all rod-shaped forms in which spores are unknown (a point in regard to which any day may bring a change in our knowledge), the genus Bacilius embracing those in which spores have been found. Of the manner of ciliation no notice is taken. Migula, on the other hand, uses the term Bacterium for all non-motile rods, and Bacillus for peritrichous species, the remaining motile forms, both lophotrichous and monotrichous, constituting a new genus, Pseudomonas. This classification very properly regards the presence or absence of spores as unimportant; but the shape of the spore-bearing rod is neglected, and no distinction is made between monotrichous and lophotrichous species. Perhaps the best plan would be to drop altogether the word Bacterium as a generic term, seeing that it is now used as a collective name for the whole group of microorganisms. The word Bacillus might then be used, in memory of Koch's first work, for all those species which, like the anthrax parasite, are nonmotile and retain their shape during sporulation.

At present we are not justified in regarding the presence or absence of capsules as sufficiently important to constitute a generic character, although very useful for the differentiation of species.

The trichobacteria are so few in number that it will suffice at present to unite them in a single family representative of another order.

Based on the characters that have been under consideration, a classification of the bacteria might be arranged as follows :-

\section{Order I. HAPLOBACTERINAE.}

Vegetative phase unicellular, spherical, cylindrical, or spirally twisted; isolated or united in chains or clusters.

Family I. CoccaceaE.

Vegetative cell spherical. 


\section{Sub-family I. Allococcaceae.}

Planes of fission without definite sequence; no pronounced colonies or growthforms, cells isolated or in short chains or irregular clusters.

Genus Micrococcus, Cohn. Non-motile. Includes most cocci, the pathological 'staphylococci,' \&c.

Genus Planococcus, Migula. Motile.

\section{Sub-family 2. Homococcaceae.}

Planes of fission in definite sequence.

Genus Sarcina, Goodsir. Three planes of division at right angles to each other. Cubical colonies, non-motile. motile.

Genus Planosarcina, Migula. Similar to Sarcina, but monotrichous, ciliate, and

Genis Pedrococcus, Lindner. Two planes of fission, alternate and at right angles. Mirrococcus tetragenus, Thiopedia (a sulphur organism), and probably some species usually termed micrococcus.

Genus STREPTOCoccus, Billroth. Planes of fission parallel, giving rise to chains; the pathological Streptococci and Leuconostoc.

Family 2. BacillaceaE.

Vegetative cell straight, cylindrical, ellipsoidal or egg-shaped; very short forms difficult to distinguish from cocci. Fission always transverse.

\section{Sub-family I. Bacilleae.}

Spore-forming rods cylindrical, unchanged.

Genus Bacillus, Cohn. Non-motile. B. anthracis, B. diphtheriae, \&c.

Genus Bactrinium, A. Fischer. Motile, monotrichous, with terminal cilium: includes provisionally all monotrichous rods whose spores are as yet unknown, e.g. Bac. pyocyaneus.

Genus Bactrillum, A. Fischer. Motile, with lophotrichous ciliation. Includes provisionally Bac. cyanogenus, and many other sporeless forms.

Genus BACTRIdium, A. Fischer. Motile, peritrichous, in some spores as yet unknown. Very numerous representatives, e. g. B. subtilis, $B$. megatherium, $B$. vulgaris (old genus Proteus), B. typhi, and B. coli.

\section{Sub-family 2. Clostridieae.}

Rods spindle-shaped during sporulation.

Genus Clostridium, Prazmowski. Motile, peritrichous; includes some of the butyric bacteria. Genera with monotrichous and lophotrichous ciliation are unknown as yet.

\section{Sub-family 3. Plectridieae.}

Rods drum-stick-shaped during sporulation.

Genus Plectridium, A. Fischer. Motile, peritrichous; some butyric bacteria, the parasite of tetanus and a methane ferment. 


\section{Family 3. SPIRILlaCEAE.}

Vegetative cell cylindrical but spirally twisted. Fission always transverse.

Genus Vibrio, Müller and Löffler. Very slightly curved rods, 'comma' shaped; motile, monotrichous. Vibrio cholerae asiaticae and numerous other vibrios of fresh and salt water.

Genus SPIRILlum, Ehrenberg. Cylindrical cells twisted in an open spiral; motile, lophotrichous. Spirillum undula, Sp. nubrum.

Genus Spirochaete, Ehrenberg. Cells long and attenuated, spirally twisted with numerous turns; cilia unknown; the cell membrane is perhaps yielding. Spirochaete Obermaieri (remittent fever).

\section{Order 2. TRICHOBACTERINAE.}

Vegetative phase an unbranched or branched filament or chain of cells, the individual members of which break off as swarm-spores (gonidia).

Family I. TRICHOBACTERIACEAE.

(a) Filaments non-motile, rigid, enclosed in a sheath.

Genus Crenothrix, Cohn. Filaments unbranched and devoid of sulphur granules.

Genus ThIOTHRIX, Winogradsky. The same, but containing sulphur granules.

Genus Cladothrix, Cohn. Filaments branched, false dichotomy (includes Sphaerotilus).

(b) Filaments motile, with oscillating and gliding movements, and devoid of a sheath.

Genus BeggintoA, Trevisan. Containing sulphur.

For the genus Streptothrix see next chapter. Further particulars as regards the discrimination of genera and species will be found in the works quoted in Appendix (No. 3). 


\section{CHAPTER IV}

\section{TAXONOMY (continned).}

\section{The Systematic Position of Bacteria; Other low Organisms with Pathogenic Properties.}

A QUESTION often asked is, whether bacteria are animals or plants? Now the terms 'animal' and 'plant' are collective terms invented by laymen to describe familiar living things, insects and elephants, mosses and oak trees, and they date from a time when such minute beings as bacteria were quite unknown. It is therefore as superfluous as it is futile to attempt, as many have done, to detect the distinguishing characters of the 'animal' and 'vegetable' kingdoms among organisms for which these terms were never intended. For this reason Haeckel and others have proposed to establish a third domain, that of the Protista, which shall include all those forms in which differentiation has not been pronounced on the lines of either animal or plant development. The new group would take up Radiolarians, Flagellata, and Infusoria from the animal side, and the Cyanophyceae as well as some low forms of Algae and Fungi from the plants. The border line between protista on the one hand and plants and animals on the other, is, it must be confessed, artificial. To these protista, which embrace approximately all those forms of life we commonly call microorganisms or microbes, the bacteria belong.

Another question almost as common as the first is, whether bacteria are fungi, as the synonym Schizomycetes or fission-fungi would seem to imply. As far as the processes of life are concerned the bacteria and fungi agree in every detail, for, with very few exceptions *, the members of both groups are unable to derive their nourishment from inorganic compounds. That is to say both bacteria and fungi are metatrophic, are restricted in their food to substances fabricated by the higher organisms. Some of them are even 
paratrophic, that is, are able to exist only upon living animals or plants. But in spite of the many points of physiological similarity between fungi and bacteria there are very wide morphological differences. In every fungus, be it a mushroom, a morel, a mildew (Fig. I5, c), a smut-fungus, or an animal parasite, like Herpes, we can always recognize two distinct parts, the mycelium or vegetative section, and, arising from this, the spore-bearing or reproductive section. The mycelium is in all fungi an irregularly felted mass of branched filaments, the hyphae, which in many cases (e.g. Penicillium, Fig. I $5, c$ ) consist of cylindrical cells set end to end, each cell having much the appearance of a rod-shaped bacterium. The fructification is of varying degrees of complexity, from isolated cells or chains of cells (Fig. I $5, c$ ) among the lower fungi
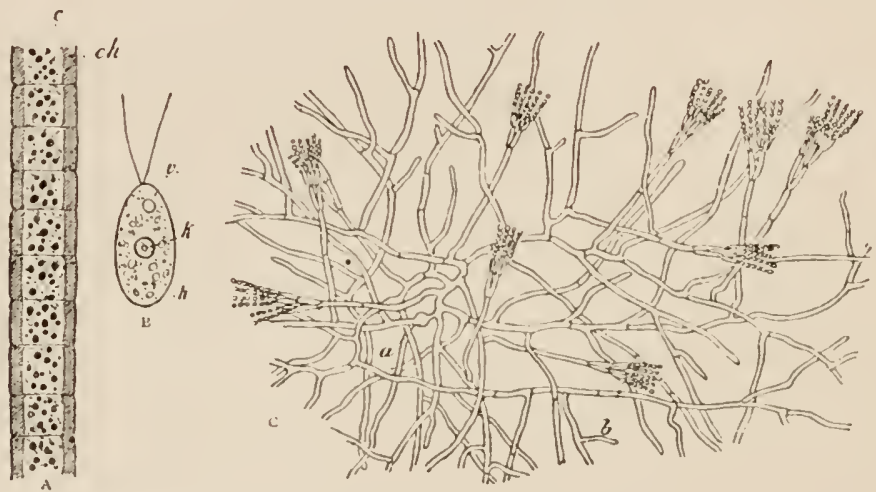

FIG. 15. A, Oscillaria temis (one of the Cyanophyceae), fragment of flament; ch, hollow cylindrical chromatophore; $c$, so-called central body, finely vacuolated protoplasm with deeply-staining granules (black). B, Polytoma uvella, flagellate with two anterior cilia; $v$, contractile vacuole; $k$, nucleus; $h$, membrane, cell contents filled witl assimilation products (paramylum). c, Penicillium glaucum (true fungus, mycomycete), myceliuin has arisen from the conidiun $a$; on aerial hyphae brush-like fruits witl chains of conidia. Magn. $a 2250, b$ about $600, c$ (from Brefeld) 120 .

up to the highly complex sporophores of the toadstools and mushrooms. Upon a suitable soil the mycelium is able to vegetate for long periods, continually producing new reproductive cells or fruits. Among the bacteria such a differentiation is nowhere to be found. Their vegetative phase is either a single cell or a cell filament on which special reproductive organs are not developed but which, like Cladothrix, breaks up entirely into gonidia. When the reproductive organs, the spores, appear, the vegetative cell as such ceases to exist. As in the myxomycetes and many other protista, it is entirely used up in the formation of the reproductive cell. The bacteria may therefore be termed holocarpous, as contrasted with the fungi which are eucarpous, that is to say, able to produce several successive fructifications from the same vegetative thallus.

Failing to find the kindred of the bacteria among the fungi we must seek them among those low organisms which we have named collectively 
the protista. Of these, two groups in particular deserve careful attention, the bluc-green algae or Cyanophyceae, and the lilagellata.

The Cyanophyccac present in their outward configuration many points of reseniblance to the bacteria. We find spherical cells (Chroococcus), rods (Aphanothece), long cell chains or filaments (Oscillaria), and spirally twisted unbranched forms (Spirulina). As among the bacteria, too, colonics or ' growth-forms' occur; some like sarcina (Glococapsa), others in flat plates (Mcrismopocdia), while sheath-bearing bacterial species like Cladothrix find their parallels among the Scytonemece (Tolypotherix) with their dichotomous false branching. But it must not be forgotten that these striking similarities to the bacteria are not confined to the Cyanophyceac; the chlorophyllbearing algae offer a like serics of parallels. The powdery green coating scen on the north side of tree-trunks, \&c., consists of minute, frec-living spherical cells (Pleurococcus), pools and ditches are often coloured green by myriads of rod-shaped species (Stichococcus), the curved vibrios have their analogy in the gracefully-formed Raphidia, and examples of sheathed filaments and capsulation are not wanting. This is not surprising, for free-living cells must have the form either of spheres or cylinders, and the simplest cell unions must be filaments, flat plates, or packets. The similarity of external configuration is only a superficial similarity and in no way justifics a systematic approximation of the two groups.

The cells of Cyanophyceae, whether free-living (Cliroococcus, Aplanothece) or united to form filaments, multiply like all other cells by division, just as do the bacteria. Just as these, too, do the isolated Cyanophyceae 'split off' from their sister cells. And for this reason, supported by the not less superficial one of resemblance in shape, the bluish-green algae ('Schizophyceae') have been placed alongside the 'fission-fungi' ('Schizomycetes') to form a separate class of plants, the 'Schizophyta.' But the 'fission' of these organisms is not peculiar to them, for it must always occur when isolated unicellular organisms divide; and the opinion that the bacteria are a series of colourless organisms parallel to the schizophyceae is not well founded.

The differences between the two groups are as numerous as the similaritics. The Cyanophyceae, if we cxcept the gliding movements of the Oscillariac, are non-motile, whercas a large proportion of the bacteria are actively motilc and possess special locomotive organs, the cilia. These are morcover present not only at the time of reproduction, but persist throughout the life of the ccll. The sporulation of the two groups is also different. The Cyanophyccae form not endospores but arthrospores, which arise by the differentiation and enlargement of a whole cell. In the finer structure of the cell again there is but one detail which the Cyanophyceae and bacteria have in common, the absence of a nucleus. In other respects the cells of the Cyanophyceae are much more highly differentiated than those of bacteria. 
The bluish-green colouring matter is borne by a special organ, the chromatophore (Fig. ${ }_{5} 5, a: c h$ ), generally having the shape of a hollow cylinder or sphere, forming the outermost layer of the cell-body and enclosing the remaining cell contents (Fig. I $5, a, c$ ). The central mass stains deeply, and thus has somewhat the appearance of a nucleus. We are, however, no more justified in describing it as a nucleus than in calling the strongly-stained granules in the protoplasm 'nuclear chromatin.' As in the case of the 'chromatin grains' of bacteria, the nature of these substances is unknown. In no bacteria, not even in the chromogenic species, is such a differentiation of the cell contents to be observed.

If we now turn to the Flagellata we find among them also many points of similarity to the bacteria. In a species like Polytoma uvella (Fig. 15, b), for instance, often found in stagnant waters, we have an egg-shaped cell enclosed in a definite membrane $(h)$, and provided with a pair of permanent polar cilia or flagella. Other forms, such as Monas, are 'monotrichous,' others again, like Tetramitus, have a brush or tuft of cilia at the anterior end of the cell. The process of 'encystment,' too, closely resembles the formation of endospores, the cell-contents contracting and secreting a new membrane, the cyst or spore thus formed being set fiee by the disintegration of the membrane of the mother cell just as are the endospores of bacteria. But notwithstanding these points of likeness the Flagellata differ from the bacteria in one fundamental feature: they possess a definite muclcus (Fig. $15, b: k$ ) like that of the cells of higher organisms. It is therefore evident that we have as little right to assume a close genetic relationship between bacteria and Flagellata as between bacteria and Cyanophyceae. The view most in harmony with observed facts is that which looks upon the Bacteria as a distinct group of protista, simpler in structure than the rest, and showing affinities to both Cyanophyceae and Flagellata. We might regard the bacteria as the more direct descendants of the ancestral stock from which these arose, the differentiation of a chromatophore leading to the Cyanophyceac and the development of a nucleus as well as the general attainment of motile power giving rise to the flagellate phylum. Among the arche-bacterial types there may well have been both motile and non-motile forms which would have been respectively the starting-points of the two branches, whilst capsulation, the production of cell-chains or filaments, and other colonial or growth forms were primitive acquirements which have reappeared again among the Cyanophyceae and Flagellata and undergone greater specialization.

The protista (micro-organisms), the simplest living things, among which we have tried to indicate the place of the bacteria, are not only manifold in form, but have very different modes of life and exercise a great variety of different functions in the economy of nature. As a general rule, these physiological features are not so conspicuous among the other groups as they are 
among the bacteria, but they become so when vigorous growth and suitable conditions of nourishment allow them to multiply rapidly. Such instances as the yeasts and the mould-fungi, with their energetic chemical effects, suffice to remind us that the bacteria are not alone in their performances.

Some of these low organisms (22) are, like the bacteria, capable of producing pathological effects, but it is very rarely that such cases present the characters of a genuine infectious disease. Only within the last few years has it become known that the yeast-fungi (Saccharomy'ctes, see Chap. XIV) are capable of developing pathological properties. Injection into animals of pure cultures of different species of brewery and distillery yeasts gives rise to processes having all the characters of true parasitic diseases, ending in many cases with the death of the animal. The germs spread to distant parts of the body and are found in all the organs as well as in the blood, but the lesions produced have not been recognized as those of any known disease in human beings. Still, an infection by yeast cells is just as conceivable as by any other organisms. It has recently been suggested that the various forms of cancer and similar neoplasms may be due to parasitic saccharomycetes, and some investigators have announced the discovery of such in stained sections. Unimpeachable results have however not been as yet attained, and it has been shown in some cases that the supposed parasites were nothing but fragments of cells and nuclei of the tissues themselves. The parasitic nature of tumours is indeed denied by some pathologists.

The thrush fungus (Saccharomyces albicans of some authors) found on the buccal mucous membrane of children belongs possibly to the saccharomycetes. Its elongated cells have much the appearance of a yeast and they multiply by budding in the same way, giving rise to mycelium-like masses which cover the culture fluid with a thick pellicle. They set up, too, in suitable media (beer-wort) weak alcoholic fermentation. Whether these masses are true mycelia or not is uncertain, and it is therefore doubtful whether the fungus should be classed among the yeasts or with such hyphomycetes as Oidium and Monilia candida.

Some of the closely allied group of Flagellata occasionally occur as parasites or messmates in the animal body (c. g. Mastigophora) which, as we have seen, have alliances to bacteria, but it has not yet been demonstrated that they are ever pathogenic. Trichomonas vaginalis is sometimes found, associated with other micro-organisms, in the mucous secretion of the vagina. A species called Trichomonas intestinalis has been found in the intestine in cases of diarrhoea and cholera, and a similar species occurs sometimes in the lung (sputum) in cases of bacterial infection. It is highly probable that all these forms are merely harmless water organisms which have found their way accidentally into the human body.

Of more importance are some of the Amocbac, that group of naked protozoa which move about by the protrusion and retraction of portions of 
their protoplasmic substance to which the name pseudopodia has been given. The amoebae multiply rapidly by simple fission and, like many other unicellular organisms, undergo from time to time a process of encystment. The cysts are enclosed in a thick membrane which possesses great powers of resistance, and from them, under suitable conditions, the new amoebae emerge. Inasmuch as the amoebae are common in ponds, and ditches, and in damp earth, it is evident that they can obtain easy access to the human body. The best known pathological species, Amoeba coli, has been frequently described in cases of dysentery. But it is not present in all cases, and it seems to occur sometimes in the healthy intestine, so that its causal connexion with dysentery has yet to be proved. I'ure cultures, free from bacteria, have not yet been obtained, nor has it been possible to cause infection by inoculation in animals. An amocba-like organism of very doubtful legitimacy has been described associated with cow-pox (Cytoryctes variolac), but it is certainly not the cause of the disease. The great prizes for the discovery of the vaccine microbe have yet to be won.

Closely reiated to the amocbae is, no doubt, the Plasmodium malariae (Hacmamoeba, Laverania), which occurs in the blood in cases of malarial fever. It is a very minute amoeboid organism which lives in the plasma, and (in greater numbers) inside the red blood corpuscles. At first colourless, it becomes pigmented later on from the accumulation of granules of a black substance (Mclanin) which arises from the decomposition of the haemoglobin. The plasmodia are seen to be most numerous during the periodical attacks of fever, one, three, or four days as the case may be, which charactcrize the discase. They then either become disintegrated or break up into a number of small spheres which have been called spores. Then the number of amoebae increases again till the next paroxysm. Whether these are true spores or not, is, like much else written about the malaria parasites, uncertain. They have not been seen to germinate, nor has it been possible to obtain pure cultures of the organisms. It seems, however, certain that they are really the cause of the disease, for its symptoms can be set up in a healthy body by the injection of blood containing the plasmodia. How the parasites enter the body, whether by the respiratory tract or the intestine, or, what is more probable, through minute wounds, such as insect-stings, is not yet known. Their habitat and mode of life outside the body are also unknown, but there can be no doubt that they are saprophytic in malarial districts *.

In the blood of birds, reptiles and amphibia, there are sometimes found

* Researches now in progress on the west coast of Africa and elsewhere seem to show that certain species of mosquitoes are the bearers of the malarial parasites which are introduced into the human body by the insects' probosces. 
parasites similar to the plasmodia, with which they have been associated to form a new group, the Hacmosporidia. Their complete life-historics are unknown, and clinical descriptions are wanting. The best known species is Drepanidium ranac, from the blood of the frog. Formerly described as a $C_{y}^{\prime} t o z o o n$, it was at one time regarded with great interest, as it was thought to be not a parasite, but a tissue clement of the frog. Its parasitic nature is now, however, generally recognized. There may be mentioned here the numerous kinds of parasitic micro-organisms, which are classed together as Sporozoa (Gregarinac, Coccidia, Sarcosporidia). They are all very imperfectly known, as it has not been possible to study them in pure cultures.

Among the organisms that have been at different times reckoned as bacteria is a small group of fungi, some of them pathogenic, known as Streptothix. They form felted mycelial masses of extremely delicate branched hyphac. - In pure cultures they are in some cases sterile, but in others bear fructifications in the form of conidia, either single or in short chains, arising from the hyphae, rescmbling in this respect the lowest fungi (Haplomycetes, Hyphomycetes), to which they undoubtedly belong. They have nothing in common with the bacteria.

There secms to be reason to think that the genus Streptothrix (Oospora) will meet the same fate as the so-called Leptomitus. Leptomitus was the name formerly given to all and every kind of filamentous fungal growth that made its appearance in neglected solutions in druggists' shops, in ink, \&c., \&c. We now know that these are not the complete forms of any specific fungus, but merely the sterile mycclia of various moulds growing slowly and abnormally in more or less unsuitable media. There can be little doubt that many growths now termed streptothrix will in like manner turn out to belong to well-known genera of hyphomycetes, which will complete their life-history when planted on suitable media. Even the best known species of Streptothrix, S. actinomyces (Actinomyces bozis), the ray-fungus, docs not scem to run through its entirc cycle of growth in our artificial cultures. Its thallus consists of branched filaments made up of cylindrical cells just as in an ordinary mould-fungus, and it grows upon agar or blood-serum in the form of thick wrinkled mats with a 'pile'-like surfacc. This velvety coat is duc to the acrial hyphae which rise vertically from the mycclium and break up at their free ends into rounded cells like conidia. Whether these really are spores or not remains to be proved.

The ray-fungus gives rise in cattle, and sometimes in man, to peculiar hard tumours, commonly in the tongue or jaw ('lumpy jaw'). These tumours suppurate sooner or later and often spread to other parts. Infection scems to be effected by the agency of sharp awns of rye and other cercals on which the fungus probably grows as a mould. They pierce the mucous membrane of the mouth, and carry the spores into the subcutancous tissuc. Attempts to 
convey the infection by the inoculation of pure cultures or pieces of diseased tissue have not been. successful. Microscopically the actinomycotic nodules are seen to consist of nests of densely matted mycelium with the surface layer of hyphae radiating outwards in all directions. The ends of the filaments terminate in club-shaped swellings, whose appearance is characteristic and unmistakable. They were formerly regarded as sporangia, but according to more recent researches are the result of a swelling-up of the cell-wall, or due to the deposit upon it of a gelatinous substance. They would therefore seem to represent rather a degenerative phase of the fungus than organs of reproduction.

A number of hyphomycetes are associated with various slin-diseases. Whether they are strictly parasitic, or whether they occur outside the living body in nature as simple mould-fungi, is uncertain. One of the commonest forms is Trichophyton tonsurans, the cause of a depilatory skin complaint known as Herpes. The mycelium is found in the epidermal scales and blisters, and grows well in artificial cultures, giving rise to chains of cylindrical gonidia. In Favus, a skin complaint common to man and animals, another hyphomycete is found, Achorion Schocnlcinii. Some observers think that this form should be split up into a number of distinct species, others are content with one. Its morphology (in a botanical sense) has not yet been fully investigated, but it belongs undoubtedly to the group of the haplo- or hyphomycetes.

The beautifully formed mould-fungi of the genus Aspergillus also occasionally invade the human body. Besides the stalked heads with their radiating chains of conidia, another kind of fructification, the perithccia, is known. These perithecia show that Aspergillus belongs to the Perisporiaceae (Ascomycetes), and for this reason some investigators have looked upon all haplo- and hyphomycetes as imperfect ascomycetes. According to this view we must expect to find some day the ascospores and asci of forms like Achorion, Trichophyton, and countless others. This is undoubtedly going too far. There undoubtedly exist simple moulds whose whole lifecycle is comprised in mycelium and conidia. Aspergillus itself lives, particularly in cultures, for years without forming ascus fruits. The conidia of the mould-fungi retain their power of germination in the dried state for very long periods.

Three species at least of Aspergillus, A. fumigatus, A. niger, and A. flavns (all with coloured spores), are possessed of pathogenic properties. If a suspension of the spores be injected into a vein in the rabbit, mycelia grow in all the organs of the body, and the abscesses formed are rapidly fatal. Among birds, spontaneous infection is not uncommon, commencing generally in the respiratory tract, the ear or the eye. Human beings, too, are sometimes attacked, but the disease remains local, not spreading to other parts of the body. In spite of these facts it is uncertain whether the 
aspergillus is the original cause of the diseased condition, or whether it merely finds an entrance in places where the natural resistance of the tissues is already lowered by injuries such as the attacks of other micro-organisms. The spores are omnipresent, and accidental invasion is so easily possible that every case must be judged on its own merits.

There remain to be mentioned as possible pathogenic organisms a few species of the genus Mucor, a mould-fungus of the order Phycomycetes. They are much less highly organized than the Aspergilli. The mycelium consists of branched, ramified, non-septate hyphac, from which rise vertical branches (acrial hyphae) that bear the spore capsules (sporangia). When injected into the blood the spores of $M$. corymbifer and of M. rhizopodiformis set up lesions similar to those of aspergillus spores; but only onc case of spontaneous infection has ever been observed in man. It is worthy of remark that those species of Mucor and Aspergillus which are capable of growing in the tissues of warm-blooded animals flourish only at high temperatures $\left(37^{\circ} \mathrm{C}\right.$.), whilst those which are satisfied with less warmth grow in the tissues either badly or not at all. 


\section{CHAPTER V}

\section{DISTRIBUTION AND ORIGIN}

\section{Distribution of Bacteria; Their modes of life; Spontaneous Generation.}

IT would be impossible to give a more concise and, at the same time, accurate account of the distribution of bacteria in nature than is furnished by Goethe's lines in 'Faust':

\footnotetext{
'Der Luft, dem Wasser wie der Erden

Entwinden tausend Keime sich

Im Trocknen, Feuchten, Warmen, Kalten!'
}

While Mephisto's haughty words :

\section{'Hätt' ich mir nicht die flamme vorbehaiten; Ich hätte nichts $A$ part's fiir mich'}

remind us that fire is the most powerful weapon that mankind possesses against bacteria. Unfortunately it is an engine of destruction that cannot always be employed.

In discussing the question of distribution, it is necessary to discriminate first of all between actively growing bacteria and latent germs. Highly resistant bacterial spores, and the hardly less resistant dried vegetative cells of many species, occur everywhere upon the earth's surface and upon the animals, plants, and inanimate objects that cover it. They are, in short, ubiquitous. But living bacteria in active growth and multiplication only occur where certain conditions necessary to their welfare are fulfilled; above all, presence of water-the vital element of all organisms-a suitable temperature and a suitable supply of food. In nature such conditions are found in ponds or rivers contaminated by dead plants or animals, in dung, manure, and moist soil. In our dwellings it is chiefly in milk and other dairy produce, stale meat, and victuals of all kinds that bacteria are found. The majority of them, both in and out of doors, belong to harmless species, but there is no doubt that occasionally pathogenic forms occur. To find out the natural haunts of these dangerous neighbours, places where they are 
present not mercly as isolated specimens but in large numbers, is one of the most important tasks bacteriology has before it.

Methods for detecting bacteria in air, water and earth, have becn greatly perfected during the last few years, but only the general principles can be treated of here: practical details will be found in works cspecially devoted to bacteriological technique (23).

Atmospheric germs may be demonstrated in a rough-and-ready way merely by leaving exposed to the air nutritive culture media, such as agar or gelatine. The bacteria that fall upon the moist surface soon multiply, each one forming around itself a small colony visible to the naked eye. For an exact determination it is necessary to allow a measured quantity of air to pass slowly through a tube, the inner surface of which is coated with sterilized gelatine. Upon this the bacteria are precipitated, and the resultant colonies can then be counted and examined in detail. There are a number of other methods in which the air is drawn through sterilized glass beads, wool, sand, or sugar. The bacteria contained in it are thus filtered off, and the material containing them can be mixed with gelatine or other nutritive media, and the colonies allowed to develop in the usual way. The air in our dwellings usually contains more bacteria than that out of doors. Ten litres of air from a hospital ward, for instance, contained from thirty to a hundred germs; the same amount of outside air only from one to five, half of thesc being the spores of fungi. Air in motion is always far more laden with bacteria than when at rest, and dusting or swceping causes their number to increase enormously. That it must be so is self-evident, for dust of all kinds is rich in spores and dried but still living vegetative bacterial cells. They are whirled up into the air with the dust-particles which also bear adherent germs, and by reason of their lightness settle down through the atmosphere very slowly.

Where there is no possibility for diseased secretions (e.g. sputum, diplitheritic membrane) to become dricd and pulverized, the bacteria found in the atmosphere are of a harmless kind, or at most pus-cocci are present. The air expired from the lungs is absolutely frce from micro-organisms, so that evidently the respiratory tract must act as a germ filtcr, the bacteria we inhale being retained within the body. But the majority of them are harmless, and moreover adhere to the mucous membianc of the nose, mouth, and pharynx, only a very small number ever getting as far as the lungs. Still, seeing that we inhale, on an average, five hundred litres of air every hour and, consequently, some fifty to two hundred and fifty germs, the danger of dust contaminated by diseasc products is very great.

Water has always been looked upon as one of the chicf agents in the spread of infectious diseases, and its bacteriological analysis is therefore a matter of the utmost importance. Most natural waters contain bacteria, and even the distilled water of our laboratorics holds sufficicnt nutritive substance 
in solution to allow some to develop. This is, however, not surprising when we consider that thirty thousand bacteria only contain about $\frac{1}{100}$ th of a'milligram of solid matter. Rain-water is contaminated with bacteria which it has taken up in its passage through the air; one sample contained thirtyfive germs per litre. The water of rivers, lakes and springs contains very varying numbers of micro-organisms, their abundance depending largely upon the amount of organic matter present. As soon as water is rendered impure by the influx of such substances as are carried into rivers by sewers and drainage canals, it ceases to be merely a liquid in which bacteria can retain their vitality for a long time unimpaired, and becomes a nutritive medium in which they proliferate with great rapidity. The water of the Spree for instance contained, above Berlin, on an average 6,I40 bacteria per cubic centimetre, that taken below the city no less than 243,000 .

The bacteriological analysis of water is a very simple process. If the microscope shows that bacteria are not too numerous, a measured quantity of water (generally I c.c.) is mixed with nutrient gelatine and poured out on to a glass plate or shallow dish. The germs distributed through the gelatine are allowed to develop into colonies which can then be counted in the usual way. The mere enumeration of the bacteria in water is of far less importance than the determination of their nature and properties. The majority of forms found in rivers and springs are of an entirely innocent character; they are bacteria whose natural habitat is water, and they perform a useful task in consuming the dissolved organic impurities. But when by any means pathogenic species obtain access to such waters these may easily become a source of infection, particularly when, as is the case with cholera and typhoid organisms, the bacteria belong to species which can live and multiply side by side with the ordinary saprophytic forms (see Chaps. XIII and XIV)*. When the water to be analysed contains a very large number of bacteria it must be diluted, before mixing, with an equal quantity of sterilized water. For the detection of isolated pathogenic forms in comparatively pure water, that is to say in water containing very few bacteria of any sort whatever, a method of 'nursing' or 'enrichment' is employed. A sterile nutritive solution (peptone-sugar) is added to the water, so that the few germs present may multiply before the gelatine is added. This method involves of course the drawback that the non-pathogenic species multiply also, and the danger that they may outnumber and overpower the less abundant bacteria we are looking for.

Numerous aquatic bacteria are able to resist freezing for long periods, and ice sometimes contains enormous quantities of them (e. g. 2,000 per c.c.). [Even glacier ice is not free from them.]

Of all the natural habitats of bacteria there is none in which they are

* For marine bacteria, see Chap. VII. 
found constantly in such numbers as in the soil. They occur both as spores and in active vegetation (c.g. nitrifying bacteria). In the soil, as in water, the presence of organic matter is favourable to their increase, and they are most numerous in cultivated earth. Garden mould seldom contains less than 100,000 germs per c.c., among them being almost always some pathogenic forms such as the bacilli of tetanus and malignant oedema. Putrefactive and pigment bacteria are also generally present as well as fermentative and nitrifying organisms. For the ordinary purposes of hygiene the cultivation upon nutrient media of the bacteria of earth, watcr, and the atmospliere, and the detection and determination of pathogenic species, are sufficient; the latter task being, however, by no means easy. Still more difficult and tedious is the systematic investigation of all the species present, necessitating as it does the employment of a number of different culture media varying in composition according to the nature of the species to be cultivated. It is not possible, for instance, to isolate the nitrogen-fixing bacteria of the soil upon a gelatine suitable for the tetanus parasite. In each case the character of the culture media must correspond to the requirements of the organism to be cultivated.

It has been customary to divide the bacteria, according to their mode of life, into two great physiological classes, the Saprophytes and the Parasites. Both groups are dependent upon other organisms for their sustenance ; both are unable either to build up their protoplasm from inorganic bodies, or to obtain, from the decomposition of such, the energy necessary for their vital processes. Those bacteria which can live and grow only within the tissues of living organisms are called parasites, those which are satisfied with the secretions or excretions of living, or the substance of dead, organisms, are called saprophytes.

But this classification no longer corresponds to facts. Being a corollary of two axioms of general physiology, it could be held good only so long as their validity was unimpaired. The first of these axioms was, that of all organisms the green chlorophyll-bearing plants alone * are able, with the aid of sunlight, to assimilate the carbon dioxide of the atmosphere, and from it to build up carbohydrates. All other living things, that is to say, plants devoid of chlorophyll, bacteria, and all forms of animal life, were supposed to be dependent, for their carbon, indirectly or directly, upon the carbon compounds already formed by green plants. The integrity of this principle has now been destroyed by the discovery of certain bacteria in the soil, which are able, even without sunlight, to appropriate the carbon dioxide of the atmosphere. The second postulate was that no organisms of any kind could fix and utilize the free nitrogen of the air. All organic nitrogen was thought to be derived from the nitrates of the soil; green plants being

* The red and the brown seaweeds also. 
again the only forms of life able to take it up in this state, other organisms receiving it from them at second hand in the shape of highly complex nitrogenous bodies. But this theory too has had to be abandoned since bacteria have been found, semi-parasitic in the tissues of plants, that can assimilate and store up free nitrogen (sce Chap. X). The two groups of bacteria which necessitate a qualification of these two fundamental principles are, in a sense, complementary to one another; on the one hand, the earth bacteria which get their nitrogen from soluble nitrates, and their carbon dioxide from the air; on the other, the bacteria living on certain Leguminosae which derive their carbon dioxide from the tissues of the plant, and their nitrogen from the air.

These facts force us to recognize the existence among bacteria of a special group of forms characterized by an extremely primitive metabolism, a physiological humility which shows them to occupy the very lowest rung of the ladder of life $*$.

Such organisms as these cannot possibly be called saprophytes, and placed side by side with organisms which, like the putrefactive bacteria, have complicated physiological requirements. A better classification would be to divide the bacteria, according to their mode of life, into three biological groups, prototroplic, metatrophic, and paratrophic (24). Prototrophic specics are those which either require no organic compounds at all for their nutrition (nitrifying bacterium), or which, given the smallest quantity of organic carbon, can derive all their nitrogen from the atmosphere (bacteria of root-nodules). With them may be classed those forms that arc able, with a minimal supply of organic matter, to break up specific inorganic bodies and derive energy from the process (sulphur and iron bacteria). In no case are the chemical changes involved clearly understood, and there apparently exist forms exhibiting gradations between the purely prototrophic and the metatrophic habit.

The metatrophic bacteria, under which heading most known species must be placed, cannot live unless they have organic substances at their disposal, both nitrogenous and carbonaceous. They flourish in every place where these are accessible, in impure water, on foodstuffs of all kinds, and in all the cavities of the body which are in communication with the exterior and offer nourishment in the form of secretions or particles of food; the mouth, for instance, and nose, the alimentary canal, and the vagina. Many of the metatrophic bacteria bring about profound changes in the chemical composition of the media in which they grow: fermentation (zymogenic bacteria), or putrefaction (saprogenic bacteria). Others break up the substratum in a less conspicuous manner, but develop particularly in media

* It seems more than probable that further investigation will result in the discovery of other low organisms (protozoa) with similar functions. 
which have already been decomposed by saprogenic species, and contain a mixture of organic compounds which serve as nutriment. Such bacteria may be termed saprophile.

In the case of some metatrophic species the chemical change effected by their growth varies according to the nature of the medium they grow in (polytrophism), while the action of others is restricted to some one specific process (monotrophism, sec Chap. III). The ability to grow in the living tissues is possessed in various degrees by different species, they are facultatize parasites (cholera, anthrax, and perhaps typhoid bacilli), but many are totally unable to exist under such conditions (obligatory saprophytes, obligatory metatrophic bacteria).

Finally, the paratrophic group includes all those bacteria that can exist only within the living tissues of other organisms. Paratrophic bacteria occur either not at all outside the animal body (gonococci), or else only as dust-borne spores or resting cells (tubercle, diphtheria). Their culture is possible only under conditions closely resembling those of the living tissues (on serum at blood-heat, for instance), and where there is freedom from competition with rapidly growing metatrophic species. Some paratrophic bacteria seem to flourish well even outside the animal body, if their growth on culture media is any criterion, but the conditions here are so very special that no conclusions can be drawn therefrom as to their behaviour in nature.

Using then the modes of nutrition as a basis for classification, we distinguish the following groups:-

\section{Prototrophic Bacteria.}

Nitrifying bacteria, bacteria of root-nodules, sulphur and iron bacteria ; occur only in the open in nature, never parasitic, always monotrophic.

\section{METATROPHIC BACTERIA.}

Zymogenic, saprogenic and saprophile bacteria; occur in the open and upon the external and internal surfaces of the body, sometimes parasitic (facultative parasites), monotrophic or polytrophic.

III. Paratrophic Bacteria.

Occur only in the tissues and vessels of living organisms, true (obligatory) parasites.

It is worthy of remark that not only the bacteria but all other organisms can be arranged in these three biological divisions. All green plants from the simplest unicellular alga up to the largest forest trees are prototrophic; all fungi and animals are metatrophic, except parasitic forms, which are paratrophic.

Seeing that the spores of metatrophic bacteria are ubiquitous, it is not surprising that all liquids offering suitable conditions of nourishment should, if left uncovered and exposed to the air, soon become turbid from the 
development of bacteria. But although it seems to us nowadays selfevident and unavoidable that such turbidity must owe its origin to the development of the ubiquitous and invisible germs-omne vivum $\mathrm{cx}$ ovothis occurrence was, until not so very many years ago, a profound mystery. It appeared absolutely certain that these living 'animalcula' must have arisen spontaneously from the non-living constituents of the liquid. 'Spontaneous Generation' (generatio aequivoca) seemed, on apparently good evidence, an indisputable fact.

The question as to the origin of life-an older problem even than that of evolution-is the natural outcome of the Kant-Laplace theory of the origin of the earth, according to which our planet was at first a molten mass that had to cool down before living things could exist upon its surface.

Whence came these first forms of life? Were they precipitated from other planets through space upon our globe, or did they arise de novo from the non-living substances that then alone existed? The first hypothesis has little to support it, and would only throw the question one step further back. It seems much more probable that the first organisms did really arise from inorganic matter by 'spontaneous generation,' and that, as the evolutionary theory assumes, all other living things have been gradually evolved from them in continued series. The doctrine of evolution is, indeed, incomplete without the assumption of such a commencement. Its possibility once granted, there is no a priori reason to deny that it still takes place, and that side by side with the ceaseless evolution of new species there may actually arise new organisms by spontaneous generation. Since we can imagine only the very simplest forms of life to be produced in this manner, it is natural that evidence for their occurrence should have been sought among bacteria and other fermentative organisms. Experiment showed that in some cases boiling for many hours did not prevent the development of bacteria in nutrient solutions, and since it was contrary to all experience that any living things could have survived such temperatures spontaneous generation seemed to be beyond dispute. When, as frequently happened, such organic infusions remained sterile after boiling, the advocates of the theory explained matters by saying that conditions had been changed, and the fluid was 'no longer suitable' for the genesis of life. They also showed that passing air through it apparently removed these unsuitable conditions, bacteria appearing again. If, however, the air had been raised to a high temperature first, or passed through sulphuric acid, or even through cotton-wool, the sterility of the liquids sometimes remained unimpaired, but not always. Contradictory results abounded and difficulties arose both for partisans and opponents of the theory. It was long before the controversy could be regarded as satisfactorily settled, but settled it was at last, and we know now that at the present day a spontaneous generation of organisms does not take place in this way. We know that 
in all those cases where bacteria appeared in liquids after protracted boiling they arose from highly resistant spores, whose vitality the heat had been unable to diminish, and we know further that those experimenters were right who sought to render air sterile by passing it over sulphuric acid or through heated tubes, and that it was for this reason that the infusions sometimes remained clear.

Infusions of organic substances, if they be only boiled long enough, will remain sterile for years, even in vessels closed only by a plug of cotton wadding. A spontaneous generation of new life never takes place; for bacteria, like all other organisms, can only originatc from pre-cxisting germs. The fantastic theories that spring up from time to time regarding the derivation of bacteria from the disintegrated protoplasm of the higher creatures are apocryphal and, like the stories of organisms that consist only of carbon, oxygen, and hydrogen, must be reccived with the scepticism they deserve (26).

Bacteriological research has thrown light from another side also upon the irrepressible theory of spontaneous generation. Before the discovery of prototrophic micro-organisms it was inconceivable how the first forms of life to appear upon the earth could have obtained their nourishment, for all organisms, including the infusoria and other protozoa, seemed to be metatrophic. Now, however, that we are acquainted with the metabolism of the prototrophic bacteria, particularly the nitrifying bacteria, we can form some conception of the mode of nutrition of the earliest terrestrial organisms 


\section{CHAPTER VI}

\section{PHYSIOLOGY OF NUTRITION AND GENERAL PRINCIPLES OF CULTURE}

Chemical Composition of Bacteria ( 27 ).

THE substance of bacteria, like that of all other living organisins, consists for the main part of water, which constitutes about 85 per cent. of their weight (human body' 6.5-70 per cent., green plants 60-80 per cent., algae about 90 per cent.). The high proportion of water (shown also in the abundance of sap-vacuoles) is due to the fact that they are aquatic, not terrestrial organisms, inhabitants of liquid media. Analysis of the substance of pure cultures freed as far as possible from the culture medium has given the following results :-

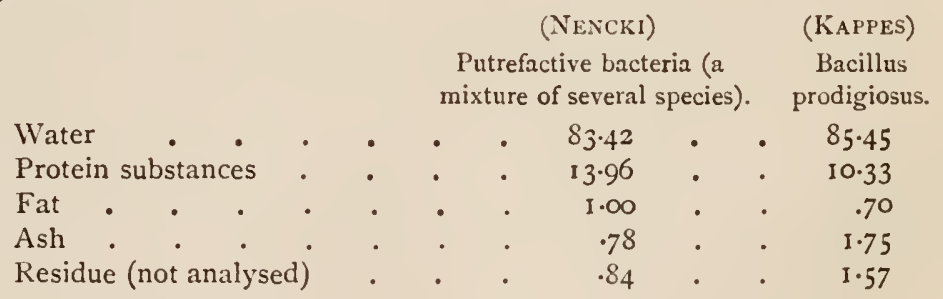

These two analyses give, of course, only a general idea of the composition of the bacterial cell. Other cases would probably show greater differences, for bacteria are, like all other organisms, dependent in their composition on the nature of the food-stuffs available. Like these also they are no doubt capable of selecting their food to a certain degree.

The quantity of the ash will be larger where the surrounding medium is rich in salts, and there will be a higher percentage of proteids in bacteria from a nutritious peptone culture than in those nourished on glycerine and ammonium chloride. Still, on the whole, their composition is evidently not widely different from that of other organisms, as the above analyses show. 
Nencki ( 27 ) isolated the protcid constitucnts of the bacterial cell by precipitation with boiling hydrochloric acid, removal of fats with ether and alcohol, solution in caustic potash and final precipitation with chloride of sodium. The substance thus obtained (mycoprotcin) agrees pretty closcly in composition with one prepared by Schlossberger from yeast, and contains 52.39 per cent. carbon, 7.55 per cent. hydrogen, 14.75 per cent. nitrogen, and about 25 per cent. oxygen. Even if we assume that this body (free from sulphur and phosphorus) is an unaltered constituent of the bacterial cell and not a decomposition product from more complex proteins, it is not necessarily the essential constituent of the protoplasm. If it were we should have to place the bacteria chemically as well as morphologically below all other organisms, where, as far as we know, the phenomena of life are inseparably bound up with the presence of highly complex bodies like nuclein and nuclco-albumen rich in phosphorus. Since, however, such compounds do undoubtedly occur in some bacteria, further investigations are necessary before we can form an opinion as to the nature and importance of mycoprotein.

Closely related to the proteid bodies (using the word in its widest sense) are those poisonous substances known as toxalbumines. The constitution of their molecule is, however, as yet quite unknown*.

Carbohydrates are probably present in all bacteria, but they certainly do not play such an important part as in the cells of higher plants, for, as already mentioned, the cell-membrane of bacteria consists not of cellulose but of a proteid substance. Apart from the not very clear indications afforded by the 'granulose reaction' in some few species (p. 13) there are no instances of differentiated carbohydrate cell-contents.

The gelatinous substance produced by Leuconostoc (see p. Io) and by some of the mucilaginous species that occur in wine and beer is probably a carbohydrate (dextrane, $\left[\mathrm{C}_{6} \mathrm{H}_{10} \mathrm{O}_{5}\right]_{\mathrm{n}}$ ) similar to cellulose and the slimy secretions of some gelatinous algae. As special temporary cell constituents must be regarded also those products of fermentation which, although formed in the cell, are not stored up but excreted as metabolic products (see Chaps. XI-XIV). The percentage of ash given in the various analyses of bacteria cannot be taken as indicating in any degree the value of salts in the economy of the cell, because the nutritive media were not prepared with this end in view.

\section{Food Stufts of Bacteria (28).}

Mineral substances are as necessary for the Bacteria as for all other organisms, albeit in a much smaller quantity. Onc milligram of living bacteria (i.e. about thirty milliards of individuals) with I per cent. of ash

* For the relations of the toxalbumines to infectious diseases, sec Chap. XVII. 
would contain only $\frac{1}{100}$ milligram of mineral salts, so that it is evident that very minute quantities of such salts are sufficient for nutritive media, say from 0.1 to 0.2 per cent.

Of the elements may be mentioned as indispensable : sulphur, phosphorus, calcium, magnesium, potassium, and sodium, with traces of chlorine and iron. Whether other alkalies such as rubidium or caesium can be substituted for potassium and sodium, or other alkaline earths, such as barium or strontium, for calcium, is doubtful. Recent experiments on the metabolism of mould-fungi render it improbable.

Full details as to the most suitable proportions of mineral salts in nutritive media will be found in practical treatises. In the following brief account of the nutrition of bacteria, the words 'necessary salts' will be understood to mean $0 . \mathrm{I}$ per cent. $\mathrm{K}_{2} \mathrm{H} \mathrm{PO}_{4}, 0.02$ per cent. $\mathrm{Mg} \mathrm{SO}$, and $0.0 \mathrm{I}$ per cent. $\mathrm{CaCl}_{2}$. Sodium and iron are also necessary, but are always present in traces in the other chemicals used unless these have been specially purified; they are likewise present in tap-water. For pathogenic forms the addition of from 0.1 per cent. to 0.7 per cent. $\mathrm{NaCl}$ is advisable; but if the media have been prepared with infusion or extract of meat it is not necessary.

These few mineral substances will be found sufficient probably for all bacteria, be they prototrophic, metatrophic, or paratrophic. The requirements in carbon and nitrogen compounds, on the other hand, are widely different for each group.

The prototrophic nitrifying bacteria grow well in a fluid of the following composition :-

\begin{tabular}{|c|c|c|c|}
\hline $\begin{array}{l}\text { Water, } \mathrm{H}_{2} \mathrm{O} \\
\text { Potassium Nitrite, } \mathrm{KNO}_{2}\end{array}$ & $\begin{array}{ll}. & \cdot \\
. & .\end{array}$ & & $\begin{array}{l}100 . \\
.05\end{array}$ \\
\hline Potassium Hydrogen Phospha & e, $\mathrm{K}_{2} \mathrm{HPO}_{4}$ & & .02 \\
\hline Magnesium Sulphate, $\mathrm{MgSO}_{4}$ & ..$\quad$. & . & .03 \\
\hline Sodium Carbonate, $\mathrm{Na}_{2} \mathrm{CO}_{3}$ & . & ${ }^{\circ}$ & .05 \\
\hline Sodium Chloride, $\mathrm{NaCl}$. & . & • & .05 \\
\hline
\end{tabular}

The nitrous acid supplies the nitrogen, and the carbon is derived, not from the $\mathrm{Na}_{2} \mathrm{CO}_{3}$, but from the carbonic acid of the atmosphere. Other prototrophic soil bacteria are able to fix atmospheric nitrogen, but require some organic compound as a source of carbon; sugar for instance.

The growth of various metatrophic bacteria upon solutions of different carbon and nitrogen compounds is illustrated by the following table. All the solutions contained the same amounts of mineral substances, and, with the exception of three cases, had an alkaline reaction; free acid, as the figures show, generally retarding development. The cultures were kept at the most suitable temperature in each case and were watched for fourteen days, so that delayed growth might not be overlooked. The symbols employed have the following meanings:- 
$+++=$ very luxuriant growth, liquid turbid with bacteria or a pellicle upon the surface (cholera, B. subtilis), or deposit of bacteria at bottom of vessel (anthrax).

$++=$ growth moderate, faint but distinct turbidity or a delicate pellicle.

$+=$ feeble growth, liquid opalescent or turbidity visible only on shaking.

$+?=$ scarcely any growth.

$\mathrm{O}=$ no growth.

\begin{tabular}{|c|c|c|c|c|c|c|c|c|c|c|}
\hline & $\begin{array}{l}\text { Source of } \\
\text { Nitrogen. }\end{array}$ & & $\begin{array}{l}\text { Source of } \\
\text { Carbon. }\end{array}$ & $\begin{array}{l}\text { Reac- } \\
\text { tionl. }\end{array}$ & $\begin{array}{l}\text { B. An- } \\
\text { thracis. }\end{array}$ & $\begin{array}{c}\text { B. } \\
\text { typhi. }\end{array}$ & B. coli. & $\begin{array}{c}\text { vibr. } \\
\text { cholerae. }\end{array}$ & $\begin{array}{l}\text { B. } \\
\text { subtilis. }\end{array}$ & $\begin{array}{l}\text { B. pyo- } \\
\text { cyaneus. }\end{array}$ \\
\hline 1 & $1 \%$ Peptone & $1 \%$ & Grape sugar & alk. & $+t+$ & $t+t$ & $++t$ & +++ & $+t+$ & $+t+$ \\
\hline 2 & " Peptone & , & Peptone & alk. & $+t$ & ++ & ++ & $+t$ & + & $+t+$ \\
\hline 3 & "Asparagine & , & Grape sugar & alk. & 0 & + & $+t$ & $+t+$ & $+t+$ & $+t+$ \\
\hline 4 & " Asparagine & , & Grape sugar & acid & 0 & + ? & $+t+$ & 0 & ++ & $++t$ \\
\hline 5 & " Asparagine & " & Asparagine & alk. & 0 & 0 & $+t$ & $+t$ & + & + \\
\hline 6 & ,, Asparagine & $”$ & Asparagine & acid & 0 & O & + & 0 & + & + \\
\hline 7 & "A Ammonium & , & Glycerine & alk. & 0 & 0 & $+t$ & + & $+t+$ & $t+t$ \\
\hline 8 & " Ammonium & , & $\underset{\text { tartrate }}{\text { Ammonium }}$ & alk. & O & 0 & $+?$ & 0 & 0 & $+?$ \\
\hline 9 & 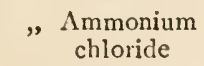 & $"$ & Glycerine & alk. & O & O & $+t+$ & $+t$ & ++ & $+t$ \\
\hline 10 & "Ammonium & " & Glycerine & acid & 0 & 0 & $+t+$ & 0 & $+t$ & + \\
\hline 11 & $" \begin{array}{c}\text { Potassium } \\
\text { nitrate }\end{array}$ & , & Grape sugar & alk. & 0 & 0 & + & $+?$ & ++ & $+t+$ \\
\hline 12 & " Potassium & " & Glycerine & alk. & 0 & 0 & 0 & 0 & 0 & $+t+$ \\
\hline 13 & none & ," & Sugar & alk. & 0 & 0 & 0 & 0 & 0 & O ? \\
\hline 14 & $\begin{array}{l}\begin{array}{c}\text { Potassium } \\
\text { nitrate }\end{array} \\
\text {. }\end{array}$ & & none & alk. & 0 & 0 & 0 & 0 & O & 0 \\
\hline
\end{tabular}

The most conspicuous result that the table shows is the great difference between $B$. anthracis and $B$. pyocyaneus. The former prospers only where peptone is available as a source of nitrogen ( $\mathrm{I}$ and 2 ), the latter grows just as well and exhibits its magnificent fluorescence upon nitre (I2). In other words $B$. anthracis is a 'peptone bacterium,' $B$. pyocyaneus a 'nitrate bacterium' approaching the members of the prototrophic group in its physiology. The latter, however, needs a special source of carbon, not being able to assimilate the carbon dioxide of the air (14). There is another numerous group of metatrophic forms which, given carbon in a suitable form, can utilise the nitrogen of ammonia compounds, and thrive as well as they do upon peptone. B. coli is one of these 'ammonia bacteria', and also $V$. cholerae and $B$. subtilis. Others, $B$. typhi for instance, are 'amidobacteria'; they cannot assimilate the nitrogen of ammonia, but grow fairly well upon amide bodies, such as asparagine and leucine. One fact must not be lost sight of if the bacteria are classified in this way, according to 
their nitrogen requirements: the power of utilising the nitrogen in different compounds is largely dependent upon the form in which the carbon is supplied. Thus, the ammonia bacteria can utilize the nitrogen of saltpetre if sugar is present, but they are unable to do so if the carbon is presented to them in the form of glycerine. No bactcria can dispcnse with nitrogen cntircly, and the feeble growth of B.pyocyancus in sugar solution alone (1.3) was probably due to the presence of impurities, or to the absorption of ammonia from the air of the laboratory.

The first attempts to characterise bacteria according to their behaviour towards different nitrogen compounds were made by Nägeli, who also examined yeasts and mould fungi in the same way. The subject has been still more recently studied by Beyerinck (28).

In medical bacteriology, fluid culture-media are now very rarely employed, having been driven out by the stereotyped recipes for peptonised gelatine and agar. That this has been disadvantageous there can be no doubt. The case of $B$. typli and $B$. coli, the one an amido-bacterium, the other an ammonia bacterium, shows the value of fluid media of varying composition for the differentiation of species. Not less important are the conclusions which may be drawn from such investigations as to the occurrence of pathogenic bacteria in nature. This subject will be more fully discussed in later chapters.

The form in which nitrogen is offered affects greatly the influence which the reaction of the culture medium has upon the growth of the bacteria. The more assimilable the nitrogen compounds, the less sensitive are the bacteria to the deleterious effect of free acid. B.pyocyaneus, as the table shows, is, when it gets its nitrogen in the form of asparagine (5-6), unaffected by the acidity of the medium which palpably retards growth when ammonium chloride is the only source of nitrogen. The extremely sensitive $V$. cholcrae is totally overpowered by free acids (4 and 6), while $B$. subtilis, which grows well on weakly acid hay-infusion, is less marked in its behaviour, and $B$. coli seems to be quite uninfluenced by the reaction.

The formation of pigment too, in B. pyocyancus, as in other chromogenic bacteria, is largely dependent upon the reaction of the medium and the nature of the nitrogenous bodies it contains. The organic compounds of nitrogen, although they all of them contain carbon also, are not in themselves sufficient for vigorous growth, as a comparison of Nos. I, 2, 3 and 5 of the table shows. The carbon of ammonium tartrate (8), for instance, is absolutely useless to $B$. subtilis, and even $B$. coli and $B$. pjocyaneus are half starved when they have no other carbon-containing compound to draw upon. The value of a special source of carbon, so clearly shown in the table, is twofold: the excess of organic carbon is used in the building up of proteids; and, morc important still, the breaking down and oxidation of 
the carbon compound provides the necessary energy for the full utilisation of inferior nitrogenous substances ( 1 I and 12).

The organic carbon compounds are of very different degrees of importance as food-stuffs, their value depending mainly but not exclusively upon their heat of combustion. Grape sugar and sugars in general are the best, then glycerine and other polyacid alcohols, such as mannite and dulcite, and finally compounds like tartaric and succinic acid, benzoic acid, and the monacid alcohols and their derivatives such as fatty acids and amines*. Compounds, in which an oxygen atom is linked by two valencies to the carbon atom, as in urea $\mathrm{CO}\left(\mathrm{NH}_{2}\right)_{2}$, or oxalic acid $(\mathrm{COOH})_{2}$, are useless as sources of carbon, as are also the cyanogen compounds. It would appear, therefore, that the carbon is in its most utilisable condition when it is linked with hydrogen in the form $\mathrm{CH}_{2}$. being less valuable as $\mathrm{CH}$, still less so as $\mathrm{CHOH}$, and not at all in the $\mathrm{CO}$ or $\mathrm{CN}$ radicles. Exceptions to this rulc, however, must not be forgotten.

Speaking generally, the best data for the discrimination of a bacterial species from the standpoint of nutritional physiology are those afforded by its behaviour towards nitrogenous compounds, the demands made for carbon being less narrow and well defined.

The paratrophic bacteria are, as our table shows, able to grow only in those solutions that contain peptone. They approach in this respect most closely to the metatrophic forms, but their requirements are often much more special. The gonococcus, for instance, grows only upon albuminous media, such as coagulated blood serum. Upon this too the diphtheria bacillus thrives best. The tubercle bacillus, which we are obliged for the present to regard as a strictly parasitic species, is able to grow upon inferior substrata, even on those of the ammonia bacteria (see Chap. XVI).

For the culture of bacteria there are commonly used, besides bouillon and other fluids, the so-called solid media prepared with gelatine or agar. The commonest recipe is an infusion of meat ( $1 \mathrm{lb}$. meat to I litre water), with about I-2 per cent. peptone and sugar, to which ro per cent. gelatine or 1-2 per cent. agar is added, the whole being boiled and filtered hot. This gives a clear gelatinous mass, in which the nutritive substances arc equally distributed throughout the non-nutrient gelatine or agar. The introduction of such culture media (29) has been an important factor in the rise of bacteriological science, for it is only by the use of casily melted and casily congealed substrata that we are able to isolate bacteria without difficulty, and obtain them in pure cultures.

The nutritive fluids mentioned in the table on p. 55 may of course be mixed with gelatine or agar, and the advantages of several methods united.

* For details, a rc-cxamination of which is desirable, sec Nägeli; appendix Noo. 28. 
If it is desirable to exclude all organic compounds, colloid silica may be used as a matrix instcad of gelatine. Great latitude is permissible in the composition of the peptone-sugar-meat solutions that are used. Almost every laboratory has its own special recipes, dictated either by whim or by the results of long experience. In many cases the media are unnecessarily overloaded with nutriment. Besides meat, hay, straw, plums, potatoes and many other substances may be used to make nutrient infusions. The wort of beer is often used, and, as an opaque solid culture-medium, potatoes are often employed. For practical details the technical handbooks must be consulted.

A part from characters such as pigmentation or the production of gas, the modes of growth of different bacteria on the same substratum are sufficiently varied to be of some use in the differentiation of species. Too much importance, however, must not be attached to these features. In fluid media, two chief types of growth are seen. In the one the liquid remains clear, in the other it becomes turbid. When the fluid remains clear we know that we have to do with non-motile bacteria with a tendency to filamentous growth. They collect on the walls and bottom of the tube in flocculent masses, which may be dislodged by shaking (Anthrax, Streptococcus). When such non-motile forms need much oxygen (B. tuberculosis for instance), they form a thick membrane, sometimes smooth, sometimes wrinkled, over the surface of the clear liquid. All isolated, non-filamentous forms, particularly the motile species (Cholera, Typhoid), cause the medium to become uniformly turbid. The turbidity varies from a dense milky opacity to a faint opalescence only visible on shaking. Strongly aerobic species form a pellicle on the surface of the fluid ( $V$. cholerae, B. subtilis).

By culture upon gelatine we are able to divide the bacteria into two groups, those which, by means of a peptonising enzyme, liquefy the gelatine and those which do not. The great majority of known forms belong to the former class; $B$. typhi, B. coli, Strcptococcus, Lactic bacilli, \&c., are examples of the latter. Further differences of growth on gelatine are brought out by the methods of 'plate' and 'stab' culture. In plate culture the melted gelatine is inoculated with a minute quantity of bacteria, or of substances containing bacteria, and then poured out in a thin layer upon glass. There it coagulates, and the germs it contains multiply. The germs being fixed produce around themselves sharply-defined'colonies, each colony having arisen from a single germ or from a few stuck together. The young colonies in particular show many characteristic features; colour, form, and contour, consistence and lustre, and the structure as seen under a lowpower lens are all useful points. A detailed account will be found in Lehmann and Neumann's atlas (30), and is needless here. The following description of the colonies of two well-known bacteria will show the nature of the differences involved better than an enumeration of all the known 
varicties of growth. The two species selected are the cholera and the anthrax bacteria.

The anthrax colonies liquefy the gelatine slowly; they are whitish and round; under a low power the edge of the colony appears filamentous, in 'tresses' and loops, not smooth; in older colonies an irregular skcin or clump lics in the fluid, almost transparent, gelatinc. The cholcra colonies liquefy the gelatine rapidly; they are yellowish whitc, and magnified show a granular texture and an undulating, not filamentous, edge; the liqueficd gelatine immediately round the disintegrating granular clumps is turbid. It must not be forgotten that many variations occur, and that closely similar forms, such as the cholera vibrio and the aquatic vibrios or typhoid bacilli and $B$. coli, are not distinguishable by their colonies alone.

The gelatine stab-culture is made by thrusting vertically into a tube of coagulated gelatine a platinum wire charged with the substance of a pure culture. Spccies which need oxygen grow only in the upper parts of the gelatine, anaerobic forms only in the deeper parts. Growth in filaments or chains shows itself by delicate threads growing out into the surrounding gelatine so that the path of the needle appears feathery or moss-like, e. g. Anthrax. Bacteria whose cells are isolated are confined in their growth to the path of the needle. Among spccies which liquefy the gelatine great importance is laid upon the shape of the liquefied tract. This may be equal all along the path of the needle, and have the appearance of a straight liquid tube in the middle of the solid gelatine, or, if liquefaction is more rapid towards the surface, a funnel-shaped well is produced. Hcre again considcrable variations take place, and closely allied species are not distinguishable by these data alone.

The surface of agar or gelatine that has been allowed to solidify in tubes in a slanting position is used for 'streak' cultures. These are made simply by smearing the surface of the substratum with a platinum wire charged with bacteria. The differences in colour, contour, lustre, and consistence are similar to those of the colonies in plate cultures. Agar is not liqueficd by any bacteria.

The modes of nutrition of particular biological groups among bacteria will be considered in the subsequent chapters. 


\section{CHAPTER VII}

\section{RESPIRATION OF BACTERIA}

\section{Aerobiosis and Anaerobiosis; Light-producing Bacteria; Marine}

Bacteria; Sulphur and Iron Bacteria.

THE old and now obsolete term ' vital air' applied to oxygen meant that without it life was impossible. Of all the axioms of physiology, none has ever seemed to be so unassailable as that which asserted the necessity of oxygen to every living thing. It appeared to be a law absolutely without exception that all animals and all plants must 'breathe' that is to say, must take up free oxygen in order to oxidise and break up the organic compounds of their food or of their tissues, and thus obtain the energy necessary for the processes of life. Deprivation of air secmed inevitably followed by cessation of life. Here again the study of yeasts and fermentative bacteria has overturned the old views and revolutionized our ideas regarding the chemistry of life.

In 186I Pasteur (31) discovered that many zymogenic bacteria could live and even set up active fermentation in the absence of oxygen; and he gave them for this reason the name of anacrobes. His statements, romantic and improbable as they at first appeared, were soon corroborated, and the general recognition of their accuracy has resulted in the division of the bacteria into two groups, the aerobes and the anaerobes. In the aerobic bacteria the process of respiration is the same as in all ordinary organisms. They absorb oxygen, and with it break up non-nitrogenous bodies such as glycerine or sugar into carbonic acid and water. They are also able, like plants and animals, to assimilate nitrogenous substances such as peptones and amido compounds, although with less gain of energy and less easily than they can carbonaceous bodies. Many of the aerobic bacteria are totally unable to live without oxygen, and when deprived of it die as would a mouse in pure hydrogen. They are exclusive or obligatory aerobes. In rarefied air or in artificial mixtures of gases their vitality is proportional to the amount of oxygen present. Under an air-pump, for instance, they 
ceas a to grow long before a vacum is reached (acetic bacteria, B. subtilis). Contrasted with the obligatory acrobic bacteria, we have the obligatory anaerobic forms which thrive only in the absence of oxygen, small traces of this gas being sufficient to inhibit growth (B. tetani, some butyric bacteria, bacillus of malignant oedema). Between these extremes there is a great host of bacteria representing every gradation between the two modes of life. These are the facultative anacrobes, which, while growing best with a plentiful supply of oxygen, are nevertheless able to exist with a very small amount, and even with none at all, although in this case their vitality is often much impaired. Anaerobic bacteria, both obligatory and facultative, are found everywhere in nature where the air cannot penetrate, or where it is replaced by other gases -in the deeper layers of the soil, for instance, in the mud of rivers and standing waters, or the ooze of the sea bottom, and in manure. In all such places anaerobic bacteria are the principal and often the only forms of life, and by the fermentative and putrefactive processes they set up they effect the disintegration and removal of dead animals and plants.* As belonging to the group of facultative anaerobic bacteria may be mentioned the lactic acid ferment, the bacteria of typhoid and cholera, many staphylococci and streptococci and most putrefactive bacteria. The power of anaerobic growth varies, even in the same species, according to the source whence the germs were derived and the mode of culture. Deprivation of oxygen affects the bacteria in many ways. Some of the pigment bacteria ( $B$. violaceus, for instance) give rise to colourless cultures if oxygen be excluded; others, like Spirillum rubrum, form pigment most plentifully under these conditions, though here again, as in so many other cases, exceptions occur. Many obligatory anaerobic bacteria (c.g. some of the butyric ferments) are motile, the energy necessary for movement being derived from the partial breaking-down of the molecules of the fermentable substances on which they grow. Access of oxygen stops the motion at once, just reversing the conditions found among the aerobic forms, where the cilia work the more vigorously the more oxygen is present, and become paralyzed at once if it be cut off. These movements, minute as they are, represent an expenditure of energy that is considerable when the size of the organisms is taken into account.

Those aerobic bacteria which possess the power of movement are attracted by oxygen. If a drop of water containing them be placed upon a slide and covered with a thin glass slip, they crowd to the edges of the preparation and around air-bubbles in the water. This property of being attracted by oxygen has been utilised by Engelmann (32) for the detection of minute traces of free oxygen. His ingenious method, which

* The chemical aspects of the phenomena of putrefaction as well as the theoretical explanation of anaerobiosis are discussed in Chap. XIV. 
employs aerobic bacteria as living reagents, has given us what has hitherto been unattainable, a micro-chemical test for the gas. It is a well-known fact that there is in green plants, going on side by side with the ordinary respiration of the cells, a second process of gaseous exchange accompanying the assimilation of carbon dioxide and also often incorrectly called 'respiration.' The carbon dioxide is split up in the green parts of the plant by the energy of the sunlight, the carbon being retained, and the oxygen thrown off into the atmosphere. Now it is not all rays that are equally powerful to cause this chemical change. The absorption spectrum of chlorophyll shows that the red rays between Frauenhofer's lines B and $\mathrm{C}$ are the most strongly absorbed by green plants, and after them that part of the spectrum just beyond $F$. It is just these regions that are most active in causing the evolution of oxygen, and Engelmann demonstrates

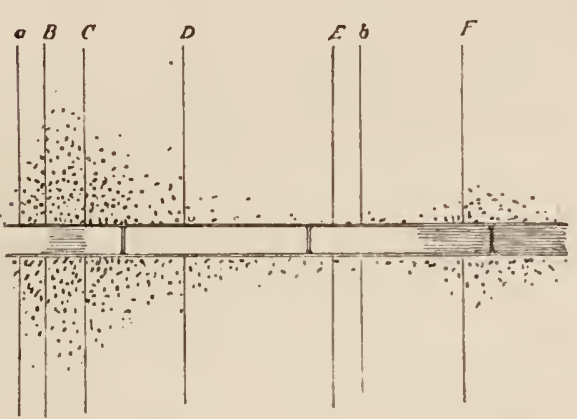

FIG. 16. Detection of oxygen by means of bacteria. The vertical lines are the Frauenhofer lines of a spectrum thrown on the field of the microscope. In the spectrum lies a filament of the alga Cladophora, and around it, at $B, C$, and F, the bacteria swarm (see text). Magn. 200 . this in the following way. By means of an arrangement of prisms in the substage of a microscope he projects a spectrum upon green algal filaments or moss-leaves lying in the field of view, the water in which they are mounted containing aerobic bacteria. If, now, the illumination be strong, and all extraneous light be carefully excluded, it can be seen that the aerobic bacteria crowd round the filaments just where the active rays fall, the chief swarm lying between $\mathrm{B}$ and $\mathrm{C}$, and another smaller one near F (Fig. I6). Around these parts of the alga only a few scattered organisms occur, showing that the evolution of oxygen is at a minimum. The application of this bacterial method for the detection of minute traces of free oxygen is an operation of great delicacy, and the results which it gives must be interpreted with great care because the movements of bacteria are very often rendered more active by other substances beside oxygen, particularly by food-stuffs, as will be explained in the section on chemotaxis. The attraction by oxygen is in fact only a special instance of chemotaxis.

The great amount of energy derived from the combustion of food-stuffs, and from the oxidation of the tissues in higher organisms, is not all expended in the form of mechanical work, but applied in part to raising the temperature of the tissues. In animals this is conspicuous in the case of 'warmblooded ' creatures, and in plants we have instances in the germinating grains of cereals and in the flowers of the Aroideae, which are often sensibly warm to the touch. Fermenting and putrefying substances also (hay, manure, cotton- 
waste) frequently become heated, the temperature inside the mass being often raised to $60^{\circ}$ or $70^{\circ} \mathrm{C}$. This spontaneous heating, which may increase to actual ignition (spontaneous combustion), is due to the respiratory activity of aerobic bacteria (thermogenic bacteria of Cohn), which set up fermentation and putrefaction.

Cohn (33) found in damp cotton-waste a micrococcus which, when well supplied with air, raised the temperature of the decaying mass to $67^{\circ} \mathrm{C}$., if care were taken to prevent radiation, carbonic acid and trimethylamine arising as respiratory products.

Light is another form in which the surplus energy of respiration exhibits itself both in terrestrial and marine plants and animals. The existence of phosphorescent insects is a matter of common knowledge. The mysterious light often seen in old willow-trees is given off by the mycelia of certain parasitic fungi. Among marine organisms there are very many kinds which are luminiferous. The phosphorescence of the sea is mainly due to lightproducing infusoria, hydrozoa, and ascidia, and in our latitudes above all to bacteria (34). The various kinds of phosphorescent bacteria have been collected together to form a 'biological ' genus Photobacterium. They include actively motile straight rods and vibrio-like forms, but very few have been completely described, and names like B. phosphorescens, B. luminosus, Vibrio albcusis must not be regarded as designating 'good' species. The faint glow seen upon decaying haddocks, mackerel, and other sea fishes, is produced by these micro-organisms. Whether any phosphorescent bacteria occur in fresh water is doubtful: but all with which we are as yet well acquainted are from the sea. Being marine organisms, the phosphorescent bacteria need in their culture-media from two to three per cent. $\mathrm{NaCl}$, besides the usual salts and peptone, and to obtain successful cultures of phosphorescent bacteria the media must contain these substances, besides some other source of carbon such as sugar, glycerine or asparagine. Phosphorescent bacteria would seem therefore to be 'peptone' bacteria, saprophytic in the sea upon dead animals and plants, from which they are washed off in countless numbers by the waves. The phosphorescent bacteria of the North Sea and Baltic flourish best at about $18^{\circ} \mathrm{C}$., but can grow quite well at much lower temperatures, even down to $0^{\circ} \mathrm{C}$., resembling in this respect the other inhabitants of northern waters. In the absence of oxygen they are indecd able to grow slowly, but are then not phosphorescent, the production of light being an exclusively acrobic phenomenon. This is evident, too, when we watch the phosphorescence of the sea, for perfectly smooth water does not shine at all, while the brilliancy of the light is always greatest upon the crests of the waves, or where the water is churned up with air in the wake of a ship. That the respiratory exchange (oxidation) of the bacteria is the cause of the phenomenon is proved by the fact that the cleath of the micro-organisms or exclusion of 
oxygen quenches the light at once, whilst a more abundant supply of highly combustible food-stuffs like carbohydrates increases it. We know of no specific substance (luciferin) to which the luminosity could be due, and the phenomenon is of quite different nature from that exhibited by phosphorescent bodies like calcium sulphide, for in the bacteria the production of light is quite independent of previous insolation.

Phosphorescent bacteria may easily be obtained by placing the flesh of fresh haddocks or herrings in a solution of two to three per cent. of $\mathrm{NaCl}$ and keeping at a low temperature $\left(5^{\circ}-10^{\circ} \mathrm{C}\right.$.). In one or two days not merely the fish, but the whole of the liquid in which they lie, give off a pale-greenish light which becomes much more brilliant if a little sugar or glycerine (i. e. respirable material) be added. The bacteria may be readily isolated by the usual methods upon peptone-sugar-gelatine prepared with an infusion of fish and common salt. The pure cultures thus obtained are so strongly phosphorescent that by protracted exposure they may be photographed in their own light. The rays given off are only the more refrangible, from $D$ to $G$. This is evident, too, from the bluish colour of the light.

A few words may be said here regarding other marine bacteria (35). The investigations of the German Plankton Expedition show that the prevailing forms are actively motile rods and vibrios, cocci being less numerous. Their distribution is determined mainly by the proximity of land, for the algal vegetation which is richest near the shore attracts myriads of marine organisms that provide the bacteria with a rich variety of nutriment. The influence of the shore extends four or five miles out to sea. The degree of illumination seems without influence, and no regularity could be observed in the distribution, but the number of bacteria per c.c. varies immensely, however far from land the sample be taken, as the following figures show:

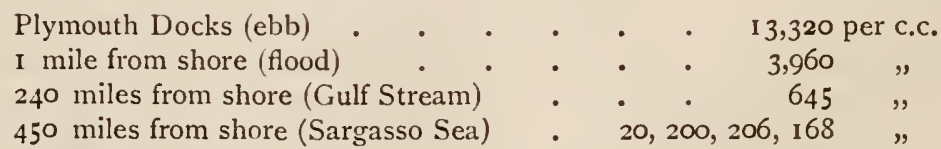

These numbers include the spores of mould-fungi. In 54 per cent. of all samples about 100 germs per c.c. were found; at depths of from 800 to 1,100 metres below the surface only from eight to twelve bacteria were present.

Specimens of ooze from the ocean bed at depths varying from $1,5^{2} 3$ to 2,406 metres were sterile; others again from 4,099 to 5,250 metres contained from one to four bacteria per c.c. This paucity is the more remarkable when we consider that the temperature was from $2^{\circ}$ to $5^{\circ} \mathrm{C}$, and the conditions altogether such that foraminifera and radiolaria occurred abundantly. Possibly the culture-medium (peptonized fish-broth gelatine) was 
at fault, since it affords nourishment only to metatrophic forms, not to prototrophic, and it is just these latter that we might expect to find on the ocean floor. It is not at all unlikely that there are species characterized by an extremely simple type of metabolism, which would throw new light upon the mysteries of marine life. Russel has discovered aerobic bacteria that reduce nitrates in samples of mud from the sea-bottom.

In the acrobic bacteria which we have been considering, respiration consists essentially in the oxidation of complex organic substances, the energy thus set free being necessary for the processes of life. In the case of the anacrobes the energy developed, although smaller in amount, is likewise derived from the splitting-up of fermentable and putrescible organic substances. Both classes, aerobes and anaerobes, are metatrophic in this respect. There is, however, in certain prototrophic bacteria a process going on comparable to respiration, but consisting in the oxidation of inorganic compounds. The micro-organisms in question are the nitre bacteria (see p. 105) and the remarkable sulphur bacteria, the classical cxamples of prototrophic respiration.

The sulphur bacteria (36), Thiobacteria (p. 13), whose cells are often crammed full of spherical refringent masses of pure sulphur, occur in nature in places where free sulphuretted hydrogen is present. Such are sulphur springs where the $\mathrm{SH}_{2}$ is principally of mineral
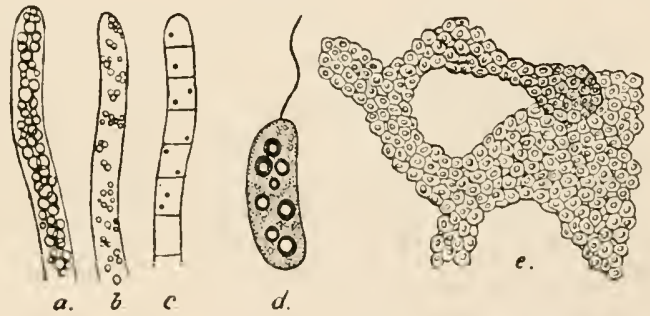

FIG. 17. Sulphur Bacteria. a-c, Beggiatoa, a full of sulphur (black rings); $b$, partly deprived of sulphur by lying $2+$ hrs. in spring water; $c$, almost free from sulphur after another day or two in pure water. $d$, Chromatium Okenit, dirty pink erythro. bacterium; $e_{1}$ piece of a mesh like zoogloea of Lamprocystis roseo-persicina. Magn. $a-c 1000, d 900, e, 500$. $a-c$ from Winugradsky, $d, e$ from Zopf. origin, and the mud of standing waters and of the sea-bottom, where it is set free by the putrefaction of dead plants and animals*. The bacteria were formerly thought to produce the $\mathrm{SH}_{2}$, and therefore to play an important part in the origination of sulphur springs, but the splendid researches of Winogradsky have shown that the micro-organisms need the gas as a food-stuff, and are unable to live without it. Thiobacteria can be found at any time of the year, but are most abundant in the early spring and late autumn, periods when the remains of the summer's vegetation in standing waters are plentiful, and when the putrefactive processes set up by other bacteria cause an evolution of $\mathrm{SH}_{2}$. The sulphur bacteria frequently form a snow-white furry coat on the rotting vegetation, with here and there pink or pale puce-coloured patches.

* The 'dead-ground' of the Bay of Kiel and the 'Limanes' of the Black Sea are instances. 
Colourless and coloured species are almost always found in close proximity to one another - the colourless forms on substrata of all kinds, the coloured ones in spots exposed to a strong light. The white furry coating generally consists of filamentous forms, particularly of the unbranched non-motile filaments of the delicately-sheathed Thiothrix, anchored by their bases to the bodies on which they grow. Here and there among them one finds the free-living, slowly-oscillating filaments of Beggiatoa (Fig. I $7 a-c$ ); unicellular colourless species also occur. The coloured forms (Erythrobactcria*) present a greater variety. The genus Chromatium (particularly C. Okenii) consists of short, plump, rod-shaped or ovoidal cells which are often present in such numbers as to give the water a reddish tinge. Thiospirillum is a corkscrew-shaped form. The dirty pink scum that coats stones and vegetation in sulphurous waters consists generally of a mixture of non-motile species, small tablets of spherical cells (Thiopedia), cylindrical species, and zoogloeae (Lamprocystis, Fig. 17 e). Winogradsky gives descriptions of nine genera.

The very fact that the red sulphur bacteria collect at those spots where the illumination is strongest would seem to indicate that there is some relation between the light and their physiological processes. To understand this connexion, however, we must first try to gain some conception of the physiology of the colourless forms. In these it is only the part played by the sulphuretted hydrogen that is clearly understood, but it is highly probable that they are prototrophic in habit. The waters in which they naturally occur contain only traces of organic matter $\dagger$; they will not grow at all upon highly nutritious media like peptonised gelatine. As a source of carbon, minimal quantities of formic or propionic acid suffice, and for nitrogen, traces of ammonia, all substances which are common products of putrefaction. They are strictly aerobic, and do not need light. They grow best in water containing 100 milligrams $\mathrm{SH}_{2}$ per litre, but are killed by a saturated solution of the gas $\ddagger$. If filaments of a sulphur bacterium already loaded with sulphur be placed in pure water they lose it all in from twenty-four to forty-eight hours (Fig. I $7 a-c$ ), and finally die from 'sulphurhunger.' But if, before it be too late, they be replaced in water containing $\mathrm{SH}_{2}$ they recover and continue to grow, the $\mathrm{SH}_{2}$ being oxidised and the free sulphur stored up in the protoplasm of the cells. The disappearance of the sulphur when the bacteria are placed in pure water is due to a further oxidatory process by which sulphuric acid is produced. This unites with the lime dissolved in the water to form gypsum. Other bacteria common in marshy places, such as Cladothrix and Spirillum, as well as mould-fungi,

\footnotetext{
* This term is suggested as perhaps the best equivalent of the German word 'Purpurbakterien.'

+ In Weilbach water only 0.0048 gram per litre, yet sulphur bacteria grow vigorously in it.

$\ddagger 4.56$ grams $\mathrm{SH}_{2}$ per litre. The Stachelberg spring contains 0.073 gram.
} 
are not able to live in water containing $\mathrm{SH}_{2}$; they perish where Chromatimn or Beggiatoa thrives.

Sceing that a solution of $\mathrm{SH}_{2}$ in water is very casily decomposed by the oxygen of the air* and free sulphur deposited, the sulphur bacteria would be able to take advantage of this oxidation for their life-processes, even if they merely had the power of existing in $\mathrm{H}_{2} \mathrm{~S}$ solution. The $\mathrm{H}_{2} \mathrm{~S}$ entering their cells would be oxidised by absorbed atmospheric oxygen, and the sulphur set free would represent an abundant source of energy for further oxidation. To explain the facts observed we need only assume further that the protoplasm increases the oxidizing power of the atmospheric oxygen and renders it 'active.' The amount of energy gained is very considerable. The oxidation of the dissolved $\mathrm{SH}_{2}$ gives seventy-one calories, and the further conversion of the freed sulphur into sulphuric acid no less than 2,109 calories.

The fact that the thiobacteria can dispense entirely with organic compounds which might be burnt up to $\mathrm{CO}_{2}$, together with their inability to live without sulphur, shows that it is the oxidation of the sulphur alone which takes the place of the respiratory processes of other organisms.

The two great physiological processes, the assimilation and storage of respirable material on the one hand, and the liberation of energy by its oxidation (respiration) on the other, may be represented in a tabular form. The following scheme shows the processes in green-plants, metatrophic bacteria and sulphur bacteria:

ASSIMILATION OF RESPIRABLE MATERIAL.

\begin{tabular}{|c|c|c|c|}
\hline & INTAKE. & STORAGE. & OUTPUT. \\
\hline Green Plants & $\begin{array}{l}\text { Carbonic acid and water } \\
\text { plus the energy of sun- } \\
\text { light }\end{array}$ & Carbohydrates & Oxygen \\
\hline $\begin{array}{l}\text { METATROPHIC } \\
\text { BACTERIA }\end{array}$ & $\begin{array}{l}\text { Organic substances (e. g. } \\
\text { sugar, which is not } \\
\text { stored but burnt up at } \\
\text { once) }\end{array}$ & & \\
\hline $\begin{array}{l}\text { SULPHUR BAC- } \\
\text { TERIA }\end{array}$ & $\begin{array}{l}\text { Sulphuretted Hydrogen } \\
\text { and Oxygen }\end{array}$ & Sulphur & Water \\
\hline
\end{tabular}

* In presence of cotton-wool or some other porous body it is even oxidized to $\mathrm{H}_{2} \mathrm{SO}_{4}$. 
RESPIRATION OR LIBERATION OF ENERGY.

\begin{tabular}{|c|c|c|c|c|}
\hline & $\begin{array}{l}\text { SOURCE OF } \\
\text { ENERGY. }\end{array}$ & $\begin{array}{l}\text { RESPIRATORY } \\
\text { GAS. }\end{array}$ & OUTPUT. & $\begin{array}{l}\text { GAIN IN } \\
\text { ENERGY. }\end{array}$ \\
\hline Green Plants & Carbohydrates & Oxygen & $\begin{array}{l}\text { Carbonic acid } \\
\text { and water }\end{array}$ & $\begin{array}{l}\text { more than } 6,000 \\
\text { calories }\end{array}$ \\
\hline $\begin{array}{l}\text { METATROPHIC } \\
\text { BACTERIA }\end{array}$ & $\begin{array}{l}\text { Organic sub- } \\
\text { stances (e.g. } \\
\text { suger ) }\end{array}$ & Oxygen & $\begin{array}{l}\text { Carbonic acid } \\
\text { and water }\end{array}$ & $\begin{array}{l}\text { more than } 6,000 \\
\text { calories }\end{array}$ \\
\hline $\begin{array}{l}\text { SULPHUR BAC- } \\
\text { TERIA }\end{array}$ & Sulphur & Oxygen & Sulphuric acid & 2,109 calories \\
\hline
\end{tabular}

These two tables give, of course, only a general view of the broader outlines of the processes. Real and apparent exceptions will occur to the student, but they do not impair the validity of the schemes as a whole. The green plants derive from the sun the enormous amount of energy necessary for the formation of carbohydrates out of carbonic acid and water, and set it free again in the process of respiration. The metatrophic bacteria make use of highly combustible organic compounds which they oxidize at once, and the sulphur bacteria are able at little cost to store up sulphur. The oxidation of this sulphur represents a very abundant supply of energy, a supply that is probably far more than sufficient to cover the wants of the organism living under the conditions already described, and building up its protoplasm from the minute traces of fatty acids and ammonia contained in the water it lives in. The question therefore naturally suggests itself whether the bacteria have not some other use for the surplus energy. We know that the nitrifying bacteria are able, without sunlight, by means of the energy they obtain from the oxidation of nitrogen, to seize and assimilate the $\mathrm{CO}_{2}$ of the atmosphere, and perhaps the Thiobacteria are able to do the same with the much more abundant energy derived from the oxidation of sulphur. Should this supposition turn out to be true, we should have in the colourless sulphur bacteria a group transitional as regards their physiology between the Erythrobacteria and bacteria of ordinary metatrophic habit (37).

The Erythrobacteria or coloured sulphur bacteria are unique in possessing the power of assimilating $\mathrm{CO}_{2}$ in the presence of sunlight by means of a special red colouring-matter (Bacteriopurpurin) which exercises a similar function to that of the chlorophyll of green plants. Engelmann has shown that the spectrum of Bacteriopurpurin is of a very peculiar character, having in addition to an absorption band between $B$ and $C$ another very broad one in the region of the invisible ultra-red, where the wave length is from $0.8 \mu$ to $0.9 \mu$. By the bacterial method he was able to prove that oxygen was evolved in both these regions, showing that the invisible heat rays are utilized for the assimilation of $\mathrm{CO}_{2}$ just in the same 
way as those of the visible spectrum. The Erythrobacteria have therefore a double source of energy, the oxidation of sulphur and the absorption of sunlight, a great advantage to them in the struggle for existence, inasmuch as they would be able to subsist in places where, from want of sulphuretted hydrogen, the colourless Thiobacteria would perish. What products arise from the assimilation of the $\mathrm{CO}_{2}$ is not known; starch has not been detected.

The Erythrobacteria are among the most sensitive plototactic organisms known, the slightest diminution of brightness repelling, the slightest increase attracting, them. The actively motile chromatia can be led about under the microscope at will by suitable manipulation of the light.

The importance of the part which the sulphur-bacteria play in the economy of nature lics in their bchaviour to sulphuretted hydrogen. They take this gas-a uscless and injurious product of organic decay--and work it up into sulphates, substances which are assimilated by other organisms, and used to build up new life.

Hardly less remarkable in their nutrition than the sulphur bacteria are the 'iron-bacteria' (ferrobacteria, 38), which resemble them somewhat in their prototrophic respiration. Our knowledge of these organisms is still very fragmentary. Stagnant pools in marshy places are often covered by a greasy-looking brownish scum, that consists mainly of ferric hydroxide, $\mathrm{Fc}(\mathrm{HO})_{3}$, together with organic matter and some phosphate of iron. The ferruginous matter is deposited as bog iron ore. By the action of reducing substances arising from putrefaction, the ferric compounds, particularly ferric hydroxide, are reduced to ferrous compounds, which are dissolved by and unite with the $\mathrm{CO}_{2}$ in the water to form ferrous carbonate. The atmospheric oxygen alone is sufficient to convert this back slowly again into ferric hydroxide, and cause its precipitation, but Winogradsky has shown that the change is not purely chemical, and that here, too, bacteria step in and accelerate the process. In the iridescent deposits of the pools cnormous numbers of short brittle tubes are found. These are the broken sheaths of an unbranched filamentous bacterium, that may be called for the present Leptothrix ochracea. These yellowish-brown sheaths are coloured bluc by hydrochloric acid and ferrocyanide of potassium; they contain ferric hydroxide. Specimens of bog iron ore from Siberia, Sweden, and North Germany contained, in thirty-threc samples, only three with large amounts of these sheaths.

Besides the empty sheaths vigorously growing mats of Leptothrix are always found, some with the cylindrical cells still in sitn, others where they have already swum away in the form of gonidia (as in Cladothrix). By placing the bacteria in water containing $\mathrm{CO}_{2}$ the iron may be dissolved out of the sheaths, leaving them colourless. If thesc bleached filaments be then put into a weak solution of ferrous carbonate of a concentration correspond- 
ing to that of the pools, the sheaths become coloured anew. It is, however, only those which contain living cells that take up iron; the empty sheaths remain colourless. It is evident from this that the living bacterial cell hastens the oxidation of the ferrous carbonate, just as it does the oxidation of $\mathrm{SH}_{2}$ in the Thiobacteria. In the iron bacteria, too, some energy, albcit a very small amount, is gained in the process.

Since the sheaths and cell membranes of other aquatic plants (c.g. Cladothrix and Crenothrix among the bacteria, Conferva (Psichohorminum) among the filamentous algae) are also turned yellow by the deposition of iron oxide, it has yet to be seen whether the iron bacteria form a separate biological group. Their nutrition as regards carbon and nitrogen also needs further investigation. They are doubtless prototrophic.

It would be justifiable from some points of view to consider the acetic bacteria in this section, but they can be more conveniently treated of with the other fermentation bacteria. 


\section{CHAPTER VIII}

\section{INFLUENCE OF PHYSICAL AGENTS}

\section{Light, Electricity ; Pressure, Temperature, Dryness and Moisture; Disinfection by means of Physical Agents.}

THE Erythrobacteria are the only forms in which nutrition is influenced by light, as in the higher plants. It is the predilection for light which causes Chromatium and other motile species to seek out the brightest parts of the vessels they are kcpt in, forming a reddish coating on the side of the glass.

All other pigment bacteria, most of which are only chromoparous, are quite destitute of the power to assimilate and split up $\mathrm{CO}_{2}$, although they naturally absorb certain rays of light. The pigment is in fact only an 'accidental' by-product of bacterial life; it is formed just as abundantly in the dark as in the light, and as a result none of the chromogenic bacteria become bleached or 'etiolated' when light is excluded. This alone shows that the pigment does not play the part of the chlorophyll of higher plants. But whilst bacteria grow just as well in darkness as in weak diffused daylight it is necessary that the illumination should remain within certain limits, the overstepping of which leads, in our cultures at all events, to the injury and death of the cells. Very numerous experiments have been made to show the deleterious effect of light on bacteria (39), but it must not be forgotten that the conditions under which bacteria occur in nature are not those of our artificial cultures, be they on solid media or liquid. In the transparent gelatine and agar it is impossible for them to obtain any shade whatever, whereas in nature, in ponds and rivers for instance, the minutest algal cell or particle of mud offers abundant shelter. It seems therefore certain that diffuse light in nature is innocuous, and even bright sunlight can only destroy a limited number, and drive the motile forms to seek shelter from 
the direct rays. We are certainly not justified in supposing that the sunshine causes disinfection on such a scale as would lead to the sclfpurification of rivers (40).

In cultures, both spores and vegetative bacterial cells are killed by exposure to direct sunlight for two or threc hours, and it is to the actinic rays, not to the heat, that the deleterious effect is due. All parts of the spectrum, however, are not equally efficacious, for if the light before falling upon the bacteria be allowed to pass through coloured solutions, such as bichromatc of potash or ammonium cupric oxide, we find that it is only the more refrangible rays that have the power of arresting growth. It has been shown that freshly inoculated broth cultures of typhoid bacilli, exposed for cight hours to light that had passed through a solution of bichromate of potash, grew well, the broth becoming turbid with the organisms. If instead of bichromate an ammoniacal copper solution was used, the bacilli would not grow at all, the broth remaining clear even after five days. Leaving aside the question as to whether the culture medium itself is injuriously changed, it is evidently the blue end of the spectrum - the photochemically active rays-that destroys the bacteria. These rays too inhibit the formation of spores in the common mould-fungus (Botrytis cincrea) during the day. Only at night is it able to develop the reproductive cells. In some fungi, on the other hand, light is necessary for fructification. Such are the little $(1-2 \mathrm{~mm}$. high) Pilobolus that projects its ripe sporangia more than a metre into the air, and Coprinus, both forms common on horse-dung. These become ctiolated in the dark just as would a chlorophyll-bcaring plant. Such examples show that it is not possible to formulate definite laws as to the action of light on colourless fungi (41). Possibly there are other 'photophile' bacteria besides the pigmented Erythrobacteria and their highly sensitive ally, the $B$. photometricum of Engelmann. As a general rule it is necessary to keep bacterial cultures in the dark, or protect them at least from intense light. Weak diffused light does no harm.

For practical purposes of disinfection on a large scale, light (even bright sunshine) is unsuitable.

Strong electric currents (44) are fatal to bacteria, their protoplasm being killed and no doubt altered in the same way as that of other plant cells is, although some of the deleterious effect may be due to the electrolytic dissociation of the nutrient media, and to the increase of temperature that the current may cause. These drawbacks are a great hindrance to the employment of electric currents for the disinfection of food-stuffs. Attempts have been made (43) in distilleries to destroy by this means the harmful bacteria without injuring the yeast cells. Currents of about 5 ampères were employed, but the practical difficulties of the process are very great, and have not yet been entirely overcome. 
Weak currents act on bacteria presumably in the same way that they do on infusoria and other motile micro-organisms (44). These are 'galvanotropic'; they collect around the kathode (negative pole). If the direction of the current be reversed, the infusoria also turn round 180 degrees, place themselves parallel to the current, and swim towards the other (now negative) pole. Experiments with bacteria have not yet been made, and they would be very difficult on account of the small size of their cells.

Very numerous and thorough experiments have been made as to the effect of Röntgen rays upon bacteria, and it has been conclusively shown that they are not even inhibitory, let alone fatal to the cells (45). The higher plants behave in the same way, and the hopes that were entertained of being able to disinfect the diseased body by means of Röntgen rays have not been realized.

High pressure (46) scems to be absolutely without influence upon bacteria. The processes of putrcfaction and alcoholic fermentation go on without interruption under a pressure of from 300 to 500 atmospheres, and the spores of the anthrax bacillus are unchanged after exposure for 24 hours to 600 atmospheres. In considering such facts as these it must not be forgotten that the weight supported by a single bacillus (say of $5 \mu$ by $\mathrm{I} \mu$ ) is extraordinarily small (even at 500 atmospheres only about 80 milligrams), so that cven at the bottom of the decpest ocean at a depth of $;, 086$ metres a coccus of $2 \mu$ diamcter would only have to withstand a pressure of 90 milligrams. In the face of thesc facts we are hardly justified in saying that bacteria are less sensitive to pressure than other organisms, because the behaviour of the larger plants and animals seems to be in this respect incommensuratc with that of bacteria.

The force of gravity exercises upon bacteria no effect comparable with the geotropism of other plants.

Bacteria, like higher plants and cold-blooded animals, are organisms whose temperature corresponds to that of their environment, falling and rising with the external temperature; they are poikilothormic (47). The rclations of the cell to temperature are expressed by specifying three points on the thermometric scalc, the maximum, minimum, and optimum. These three cardinal points hold good for all organisms. The different functions of Jife are performed best at different temperatures, and the temperatures most favourable to growth, to movement, to fermentative power, to virulence, to sporulation and to germination are probably different in each case, but a general average, coinciding with the most rapid multiplication of the cells, is spoken of as the 'optimum.' For all species these three cardinal points vary slightly within certain limits.

The following cardinal points are those which hold good for growth. The maximum is that temperature which cannot be exceeded without 
cessation of growth, the minimum is the lowest temperature at which growth even of the feeblest kind is possible.

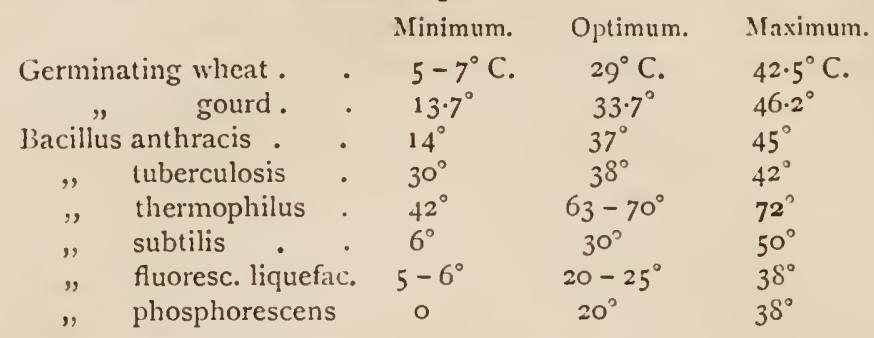

The table shows that wheat scedlings and free living metatrophic bacteria like $B$. subtilis and $B$. liquefaciens need approximately the same temperature, while the gourd plant, an inhabitant of warmer zones, requires more, as do also the cholera and anthrax germs, $30^{\circ}$ to $40^{\circ}$ being the optimum. The phosphorescent bactcrium from our cold northern seas has the lowest minimum of any, and at the other end of the scale we find the representative of that curious group the thermophile bacteria. The tubercle bacillus has the narrowest temperature range of all, only twelve degrees separating maximum and minimum. It is, to use an expression borrowed from animal physiology, stenothermic, as are all the strict parasites on warm-blooded animals. The metatrophic bacteria, on the other hand, arc eurythermic, and can endure great variations of temperaturc with a difference of as much as $30^{\circ}$ between maximum and minimum.

Bacteria which are pathogenic for warm-blooded animals, and at the same time curythermic (e.g. B. anthracis), are very probably metatrophic in our climate.

The thermophilic bacteria (48), singular as it may scem, arc very widely distributed even in our temperate climate, and a large number of species have been isolated from the soil and from sewage. It is difficult to see where these bacteria (mostly non-motile aerobic rods) find the necessary conditions of existence. Strong sunshine sometimes heats the surface of the soil to $70^{\circ} \mathrm{C}$. and might permit the development of such forms, but they must be subject to long periods of quiescence. Manure and other substances that become heated during fermentation are their most likely habitats.

In B. thermophilus the optimum reaches the temperature of coagulation of most proteids and the maximum exceeds this. We might be inclined to regard the protoplasm for this reason as different from that of ordinary cells, but we must not forget that in all proteid bodies the temperature of coagulation varies very much according to the reaction of the protoplasm, the amount of salts present and other factors, so that we are not justified in looking upon the thermophile bacteria as being miracles of nature. Besides, we know of other organisms that live at very high temperatures. In the hot springs of Ischia and around the 'fumaroli' at Naples micro- 
organisms are found in water at $60^{\circ} \mathrm{C}$. and more. In the drainage from the Carlsbader Strudel $\left(54^{\circ}\right)$ there is a thick growth of Leptothirix with green Oscillariae, and in other thermal springs crustacea and insect larvac are known to occur at $60^{\circ}$.

Bacteria may be roughly divided according to the optimum temperature into two great groups, those which grow best at about $20^{\circ} \mathrm{C}$. (B. fluorescens, B. phosphorescens, B. prodigiosus, and many other metatrophic forms), and those which need a higher temperature. For the maintenance of a regular high temperature special incubators are used. These secure great uniformity of any desired degree of warmth by the use of some form of thermostat, and are subject to variations of 0.1 to $0.5^{\circ}$ only. Still better is a whole room maintained at a constant temperature. Practical details will be found in the works cited in No. 3 of Notes (p. I69).

When the temperature at which bacteria are grown approaches either the maximum or the minimum, not only is growth arrested, but all the functions of the cell are enfecbled. Continued cultivation under these circumstances, particularly at tempcratures near the maximum, effects injuries from which the cell recovers only very slowly when the optimal conditions are restored. (See Lects. III. \& XVII.)

Exposure to extreme cold has, apart from arresting growth, very little ill-effect upon bacteria. In this respect they resemble other poikilothermic organisms, falling into a lethargic state (hibernation). Sporeless anthrax bacilli can endure a temperature of $-26.8^{\circ}$ for twelve days without injury, whilst the spores show no decrease of vitality or virulence, after exposure for twenty hours to $-\mathbf{I} 30^{\circ}$. Long imprisonment in ice and even repeated freezing and thawing can be endured for wecks and months, bacteria behaving in this respect like algae and other water plants. The cold of our winters is therefore quite inadequate to kill bacteria, and the application of artificial low temperature is equally useless as a means of disinfection (49).

In sharp contrast to this indifference to cold is the behaviour of bacteria towards heat. If the maximum be exceeded death speedily follows (largely as a result of the coagulation of the protoplasm), and consequently a temperature of $50^{\circ}$ or $60^{\circ} \mathrm{C}$. for ten minutes is sufficient to kill the sporeless regetative cells of all but the thermophile bacteria. At $70^{\circ}$ five minutes is sufficient. It is on this principle that the prescrvation of tinned foods is now so largely carricd on and the 'Pasteurization' of wine (heating for half an hour to $70^{\circ}$ ) is another instance of its application. In 'fractional sterilization' as applied to culture media like blood scrum, which cannot be heated to $100^{\circ}$, the same result is aimed at, namely the destruction of the vegetative cells. Spores which have resisted the first heating are then allowed to germinate and are killed by a second heating, the process being repeated five or six times if necessary until sterility is secured. At the present time hundreds of such sterilizers are in daily use in the service of antiseptic surgery. 
The spores (47) are always far more resistant than the vegetative cells, and their resistance is proportional to thcir dryncss. This must not be looked upon as a peculiarity of bacterial spores, for all resting protoplasm is resistant in consequence of the small amount of water it contains. Grains of corn rendered as dry as possible in a desiccator can cndure from $100^{\circ}$ to I $10^{\circ}$ dry heat for hours without losing the power of germination. They are in this respect not far inferior to anthrax sporcs, which succumb to $140^{\circ}$ in thrce hours.

For many objects disinfection by dry heat is impracticable, as they would be injured by the high tempcraturc. The method can, however, be advantagcously used for disinfection of the glass ware used in bacteriological work, but for surgical instruments and dressings boiling watcr or hot stcam is to be preferred.

Spores are morc quickly destroycd by moist heat, although if the temperature of boiling water be not excecded some hours are necessary to destroy such resistant spores as those of $B$. subtilis and its allics. Anthrax spores are generally killed by boiling water in from two to five minutes, but one must always reckon on finding a few of much greater resistance that need ten or twelve minutes.

Moist seeds are much more quickly destroyed, being killed below boiling point. The cause of the greater resistance of bacterial spores is not known, but probably both the impermeability of the membrane and the durability of the protoplasm play a part. If the impermeability of the membrane be the causc, it is casy to conceive how the spores can remain some time in watcr before the protoplasm can takc up moisture. They would even in boiling water be cxposed at first to a $d r y$ heat. This view gains in probability when we consider that the spores of $B$. subtilis germinatc very slowly, many hours passing before they swell and lose their lustre by absorbing water. This stage is passed through more quickly if the spores be boiled for five minutes. It seems as though the spore membrane were at first very impervious to water. We know too that this is the case with the resting spores of algae and fungi. The resting cells of other low organisms such as amocbae, infusoria and flagellata, although not yet investigated, are doubtlessly similar in this respect to bacterial spores.

The sterilization of fruits and prescrves by boiling in closed vessels is familiar to all and has been in use since the last century. A discussion of the various kinds of disinfectors, of the Koch steamer, and the autoclave that by means of superheated steam kills the toughest spores in one minute at $140^{\circ}$ would be out of place here. They are used for the sterilization of culture media. The uses to which these physical methods of disinfection are put in public sanitation will be found in text-books of hygiene.

All plants, those of our climates as well as those of the steppes and deserts, have to protect themselves against dryncss in times of drought. 
Mosses and lichens on naked rocks shrivel up to dry friable masses, falling into a resting condition in which they remain for weeks without losing the power of growing again as soon as they receive moisture. The algae of ponds and those that live on soil that is only periodically wetted can also withstand drought for months. In all these cases it is the whole plant that falls into a resting-stage, in which it can retain its vitality for long periods, although not for an unlimited time. Among animals, too, many instances are known (rotifers, tardigrada, anguillulae) in which the whole organism can remain dried for wecks and months, and then be recalled to life by moisture.

Organisms which are provided with a morphologically specialized restingstage (spores, cysts, or seeds) can still better resist the effects of dryness. The spores of the Smut fungus, Ustilago carbo, germinate when placed in water, even after lying for ten years in an herbarium; and wheat grains sprout after ten or even twenty years if they have been carefully protected from moisture. This suspension of vitality cannot, however, go on for unlimited periods, and the miraculous stories of ' mummy wheat' germinating after thousands of years are certainly fabulous.

The spores of bacteria (50) can also remain dormant for a very long time ; those of Anthrax, for example, germinate after ten years' quiescence. Thus the resting-stage among bacteria is of similar duration as among other organisms, and is shortened in the same manner by moisture or damp air. Many bacteria can resist drying for long periods even in their vegetative condition. Dry tubercle bacilli retain their virulence for weeks, as do also the bacilli of diphtheria and typhoid fever and pus cocci. True aquatic bacteria, on the other hand, such as the cholera vibrio, are lilled by drying in from two to five hours*.

For the purposes of practical disinfection drying is not applicable, but it seems to play an important part in the destruction of bacterial cells in nature. Still, if dried bacteria, during short periods of moisture such as continually occur, can find suitable nutriment they revive again, and multiply, only to fall again into the resting-stage. For this reason it is not to be expected that disease products, or earth contaminated with organic substances, will be spontaneously disinfected by mere exposure to the air.

* For the relation of these phenomena to infectious diseases see Chaps. XV. and XVI. 


\section{CHAPTER IX}

\section{THE ACTION OF CHEMICALS-CHEMOTAXIS AND CHEMICAL DISINFECTION}

ExAMINATION of a drop of stagnant water under a medium-power objective shows that the bacteria and infusoria it contains are not evenly distributed through the liquid. They gather in clouds around particles and flocculi of decaying organic matter, to which they seem to be attracted as fish are attracted by bait, or ants by aphides. 'Instinctive' is the term (favoured of anthropomorphists) applied to such actions when performed by the higher organisms, and yet we see them here carried out with unfailing accuracy by creatures whose whole body consists of but a single cell. Are then the bacteria too to be credited with instinct? That would indeed be a surprising conclusion!

This capability shown by unicellular organisms of being attracted by food-stuffs was first carefully studied by Stahl (5l). He showed that the naked protoplasmic masses which form the plasmodia of the myxomycetes were affected by a nutritive body placed in their neighbourhood. They turned towards it on whichever side it was placed, suggesting by this action the term Trophotropism as a suitable descriptive name for the phenomenon. At about the same time Pfeffer (52) investigated from a more general chemical standpoint the effects of such stimuli upon the movements of bacteria, protozoa, and the spermatozoids of the higher cryptogams, and was able to show that the nutritive value was not the sole and only determinant, but that other more recondite factors were involved, factors based on the chemical constitution of the substance employed as a stimulant. For this reason he introduced the now generally adopted expression Chemotaxis.

Pfeffer's method for the study of the chemotaxis of bacteria is simple and efficient. A capillary tube, sealed at one end and about $5^{-10} \mathrm{~mm}$. long, is half filled with the liquid to be tested, e. g. a 5 per cent. slightly alkaline solution of Liebig's Extract, or of peptone, in such a way that a bubble of air remains in the closed end. The outer surface of the glass is carefully cleaned from any traces of the broth, and it is placed in a drop of water containing bacteria in such numbers as to be slightly turbid. In five or ten seconds it can be seen that the bacteria are more thickly congregated around the open end of the capillary than elsewhere, and in a few minutes 
they form a dense swarm there, and begin to enter the tube. The movements of the bacteria in the drop become more lively as soon as the diffusing peptone reaches them, and at the entrance of the tube they are a whirling, 'buzzing' mass, like hiving bees. The potential energy of the food-stuff has been converted into the linetic energy of the vibrating cilia. If now a cover-glass be laid upon the drop another kind of chemotaxis can be observed. The bacteria which have entered the tube move upward, attracted by the air in the blind end, and in about half an hour that section of the capillary immediately below the bubble is plugged by a thick mass of organisms. But these phenomena, the attraction by food and the attraction by air, might as well be called trophotropism as chemotaxis, the latter being shown in its purest form when solutions of salt are employed. For instance, a 1.9 per cent. solution of $\mathrm{KCl}$ has a powerful effect, and draws the bacteria into the tube just as peptone does, being still feebly attractive even in a dilution of 0.019 per cent. Among the alkalies, potassium is chemotactically the most powerful, then sodium and rubidium. The alkaline earths are less effective. The influence of a salt is attributable mainly to its electropositive constituent, the acid radical acting much more weakly. Further details of this interesting subject will be found in the works of Pfeffer already cited. Among organic substances with a high nutritive value, asparagin and peptone may be mentioned as being strongly chemotactic, whilst sugar, one of the best food-stuffs and richest sources of energy, has but little attractive power. Glycerine is in

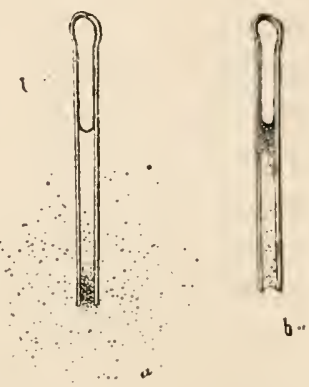

FIG. 18. Chemotaxis. A part of a drop of water containing Bacillus furorescens liquefa. ciens, and a capillary sealed at one end and partly filled with 5 per cent. weakly alkaline peptone solution; at $l$ an air-bubble. About 4 minutes after introduc. tion of capillary, the bacilli have collected round the open end of the tube, positive chemotaxis. $\frac{1}{4}-\frac{1}{2} \mathrm{hr}$. later, the bacilli, driven by want of oxygen, have collected close to the iar-bubble. From nature. Magn, so. all cases, as far as is known, inactive.

Contrasting with the phenomena just described, is the power which certain substances have of repelling bacteria. This is linown as negative chemotaxis. Free acids and alkalies have this effect, and capillaries filled with their solutions invariably remain empty. Alcohol too is 'instinctively' despised by micro-organisms. In some salts the action of the acid radical and that of the base neutralize each other (e.g. carbonate of ammonia $\mathrm{I} \cdot 76$ per cent., phosphate of potash (monobasic) 3.48 per cent.), and the bacteria then take up a mean position at a certain distance from the mouth of the tube.

In the case of negatively chemotactic compounds, the poisonousness of the substance is no more a criterion of its repellent power than the food value is an index of the attractive power in positively chemotactic bodies. For instance, a solution of 0.019 per cent. potassium chloride plus $\mathrm{C} .01$ per 
cent. mercuric chloride attracts bacteria by reason of the potash it contains, but they rush into the tube only to meet their death from the mercury salt. It would therefore seem that chemotaxis, useful as it must be to bacteria in the search for food, may lead them to destruction, although of course they are not exposed in nature to the temptations of such fatally seductive capillaries.

If the facts gained by these experimental observations are to be employed to elucidate the life-history of bacteria in their natural habitats, in water, in the soil, or in the tissues of the diseased body, a number of considerations must be borne in mind. In the first place, chemotaxis can only take place in media which permit free movement, in liquids. Secondly, different kinds of bacteria by no means react in the same way to the same substances. Furthermore, it must be remembered that the sphere of influence of such a capillary is very small. It is not possible to entice into it all the bacteria swimming in the drop. It would not be possible, even if we could renew the solution in the capillary as fast as it diffused so that it could continually give off a diffusion-stream, as perhaps the decaying flocculi in stagnant water do. For the bacteria would be already stimulated by the diffused substance, and to enable them to again react chemotactically a much higher concentration would be necessary. Pfeffer has shown that 'Weber's Law' (Psycho-pliysical law of Fechner), which formulates the relation between strength of stimulus and intensity of sensation, holds good for the chemotactic movements of bacteria. Weber's law is to the effect that an external stimulus just sufficient to give rise to a sensation must be increased in a definite ratio in order to awaken that sensation again. For instance, a weight of one ounce laid upon the hand gives rise to the sensation of pressure upon a certain spot. If now upon the weight a further load of $\frac{1}{10}$ oz. be laid no further sensation is aroused. Not until the original weight has been increased by one-third (i.e. to $\mathrm{I} \cdot 33 \mathrm{oz}$.) is the sensation of pressure aroused again. Had ten ounces been the weight originally employed it would have had to be raised to 13.33 ounces. For thermal stimuli the increase must amount to $\frac{1}{30}$ th, and for visual stimuli to $\overline{1} \frac{1}{0}$ th of the original stimulus in order that it should again cross the threshold of sensation and enter our consciousness. Precisely the same law governs the phenomena of chemotaxis. In the case of one of the putrefactive bacteria the stimulus has to be increased five times before chemotactic movements are again set up. If the organism be already in a 0.1 per cent. solution of extract of meat the capillary must contain a 0.5 per cent. solution, if it be in I per cent. the tube must be filled with 5 per cent. bouillon before a reaction follows, while to start very active movement we should have to fill the tube with a broth ten or twenty times as strong as the surrounding fluid. These facts should not be forgotten when we attempt to explain by chemotaxis the behaviour of bacteria in the living body, or the 
emigration of leucocytes towards a bacterial focus (53). An exact knowledge of the conditions involved is impossible, inasmuch as the composition of the fluids in which the tissues are bathed and the amount of chemotactic substances they contain are entirely unknown. For this reason considerable discretion must be exercised in the use of the word chemotaxis if it is not to become a mere shibboleth (sce Ch. XVII).

In the case of some substances, peptone for instance, the absolute amount sufficient to cause perceptible reaction is very minute. Pfeffer calculated that a capillary filled with 0.01 per cent. peptone solution, a strength just sufficient to attract bacteria in water, contained only

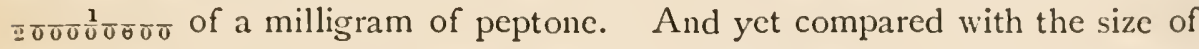
the bacterial cells this quantity is not disproportional.

Like all other processes that depend ultimately upon the activity of the living cell, the phenomenon of chemotaxis is extremely obscure. This much however we know, that the effect of the substances diffusing from the capillary is to cause the bacteria to turn (hence chemo-taxis) in such a way that their longer axes are parallel to the direction of the diffusion streain. They then swim either against the stream (positive chemotaxis) or with it (negative chemotaxis). Why one substance should act positively and another negatively is at present quite inexplicable. A more detailed discussion would be beyond the scope of this treatise, and would be at best fragmentary. Those substances which in weak solutions exercise a positive action on bacteria have in some cases ( $\mathrm{KCl} 19$ per cent.) the same effect when the solution is concentrated; in other cases the bacteria are repelled. Neutral salts such as $\mathrm{KCl}$ and $\mathrm{NaCl}$ can be endured in very high concentrations. The hay bacillus, for instance, grows well in an infusion containing 9 per cent. $\mathrm{NaCl}, 5$ per cent. sal ammoniac, i I per cent. $\mathrm{KCl}$, or 10 per cent. $\mathrm{KNO}_{3}$. Such substances are not poisonous, and arrest growth finally by the osmotic pressure they set up.

Of great interest are those poisonous compounds which even in minute quantitics destroy the life of the cclls. They are not by any means especially poisonous for bacteria. A one-tenth per cent. solution of corrosive sublimate $\left(\mathrm{HgCl}_{2}\right)$ kills tubercle bacteria in ten minutes, and the cells of algae are destroyed just as soon, if not sooner. In a I per cent. solution of carbolic acid both tubercle bacilli and ordinary plant cells are killed in one minute. With few variations and exceptions the protoplasm of all organisms is destroyed in about the same time by the more powerful poisons.

The destruction of bacteria by poisons-chemical disinfection (54)-is employed in all cases where the application of the methods described in the last chapter is impossible on account of the injury caused by the heat.

The resistance of bacteria to chemicals is not only different in different species, but varies also according to many external circumstances. It is greatest when the organisms are growing under the most favourable 
circumstances, when temperature, food, and other conditions are all optimal. Bacteria are, in short, like all other organisms, strongest and most resistant when they are in the best health. There is always a great difference between spores and the far less resistant sporeless vegetative cells, so that a disinfectant can only be considered effective when it is able to kill spores. In practice, circumstances may sometimes arise when this requirement may be dispensed with.

Every disinfectant must be tested on the following three points :

I. In what concentration must it be added to a given substratum in order to prevent the development and multiplication of bacteria without killing them? This is the coefficient of inhibition.

II. What is the shortest time in which sporeless bacterial cells in water at $20^{\circ}-25^{\circ} \mathrm{C}$. are killed by a substance in medium concentration (i. e. not sufficient to cause plasmolysis or other injury)? This is the inferior lcthal coefficient.

III. What is the shortest time in which, under the same conditions, the spores are killed? This is the superior lethal coefficient.

Laborious investigations without number have been made with the object of determining these three values for all kinds of organic and inorganic compounds, and we have now a number of carefully-chosen substances that are suitable for use as disinfectants. The following tables give a few examples. Further details will be found in the works cited in Notes 3 and 54 .

\section{Coefficient of InHibition for Anthrax Bacilli in Ox-Blood Serum. From Behring (54).}

The numbers indicate the number of cubic centimetres of serum in which one gram of the solids or one cubic centimetre of the liquids was dissolved; for instance, 'Corrosive Sublimate, $10,000^{\prime}=1$ gram $\mathrm{HgCl}_{2 .}$ in Io,000 c.c. serum :

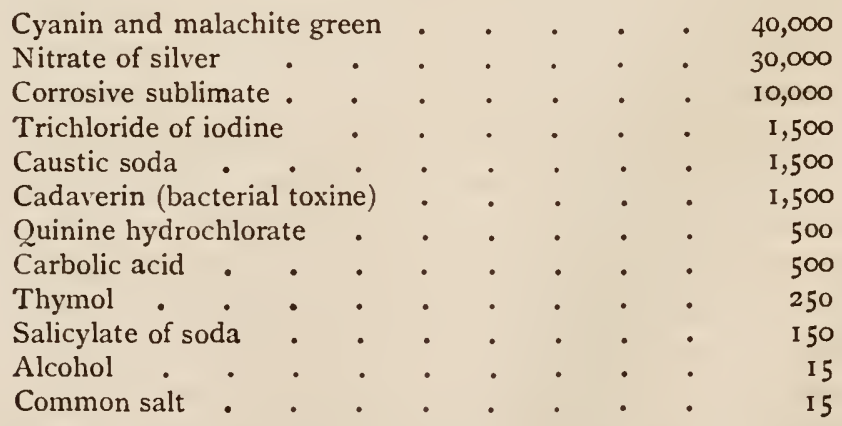

The extraordinarily small quantities which are in some cases sufficient to 
prevent putrefaction do not lill the bacteria, they only arrest growth and multiplication.

II. Lethal Value for Sporeless Tubercle Bacilli.

Inferior lethal coefficient; the time is given in which tubercle bacilli (from cultures, not in sputum) are killed. From Yersin (54).

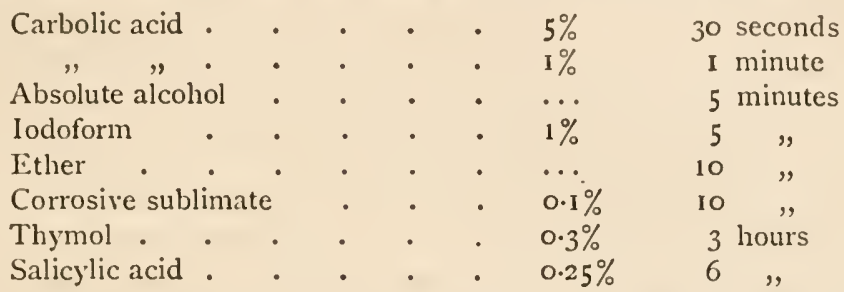

To kill the bacteria in sputum, where they are embedded in mucus, a much longer time is necessary, c. g. Io per cent. lysol for twelve hours. The figures in the table were obtained by mixing tubercle bacilli from a growing culture with the fluids, taking out samples from time to time, and sowing them on culture media. The values given may be regarded as being good for most sporeless bacteria, the sensitiveness of which is illustrated by this example.

III. Lethal Value for Anthrax Spores. From Paul u. Krönig (55).

Substance.

Corrosive sublimate
Concentration. $1.7 \%$ ( 16 litres) $12-14$ minutes

$0.84 \%(32,24-30 \quad$,

$0.42 \%(64) \quad 45-,60 \quad$, $0.2 \%(128) 60-80$, $0.1 \%(256,$,$) more than 120$ minutes

Nitrate of silver - . $4.25 \%(4, ")$ I $5-16$ minutes

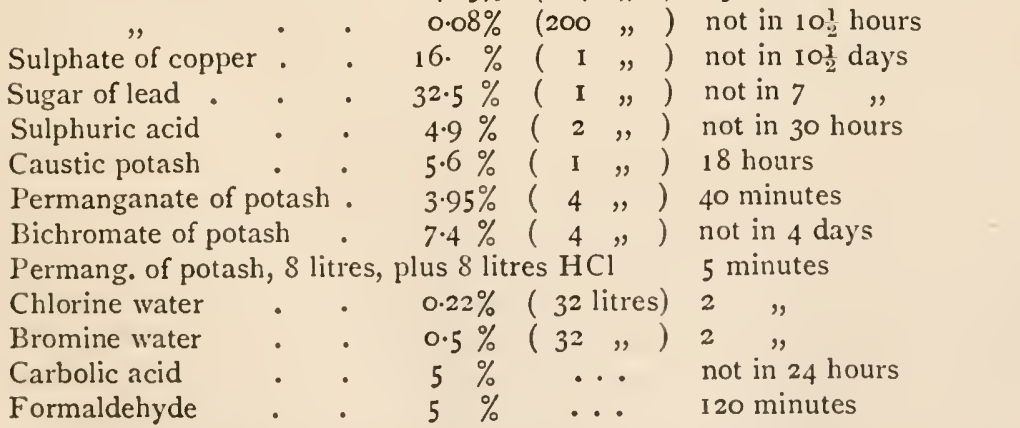

The lethal concentration for spores is determined in the following way. A suspension of the spores in water is dried upon silk threads, pieces of glass, or, better still, upon carefully-cleaned garnets, which are then laid in the disinfectant. Specimens are taken out at intervals and sowed in nutri- 
tive media. Before this is done, however, the threads or garnets, as the case may be, must be freed from any adherent disinfectant. Washing with distilled water is not enough for this, they must be rinsed with ammonium sulphide, and the soluble metallic salts precipitated and rendered harmless. Only in this way is it possible to obtain reliable results, for the small quantity of disinfectant adherent to the spores, although not sufficient to kill them under ordinary circumstances, might do so during the stage of imbibition, and would certainly destroy the germinating rod, thus giving a false idea of the disinfecting power of the substance. In the examples given in Table III, from 15,000 to 20,000 spores were killed in the stated times. The concentration is given in per cents., and also in terms of 'molecular dilution'; for instance, 'Corrosive Sublimate, 16 litres,' means that sixteen litres of the solution contain the molecular weight of $\mathrm{HgCl}_{2}$ (i. e. 27I) expressed in grams, so that 100 c.c. of the solution contains $\frac{2}{1} \frac{7}{6} 0$ grams $=1 \cdot 7$ grams. This method of calculation, so much used in modern chemistry, is given because it permits an easy comparison of different salts - a comparison of molecule with molecule, so to speak.

According to Koch absolute alcohol, concentrated glycerine, concentrated $\mathrm{NaCl}$ solution, and distilled water do not destroy anthrax spores, even after acting on them for months. The table shows that the halogen elements (chlorine, bromine, iodine) are the most powerful, and, among the metallic salts, corrosive sublimate. Nitrate of silver has some little effect, but sulphate of copper and acetate of lead are powerless. Free acids or free alkalies must be very strong to act as disinfectants. Chromate of potash, too, although it is a powerful oxidizing agent, has little germicidal power, whilst potassic permanganate, far less effective as an oxidizer, is a powerful disinfectant.

Tables II and III show the great difference between spores and vegetative cells in their behaviour to disinfectants. Five per cent. carbolic acid, for instance, which kills tubercle bacilli in thirty seconds, does not destroy anthrax spores in twenty-four hours; with 0.1 per cent. sublimate, the times are ten minutes and sixty or eighty minutes respectively. Absolute alcohol, powerless against anthrax spores, kills tubercle bacilli in five minutes. The resistant power of the spores depends, no doubt, principally on the great impermeability of the spore wall to dissolved substances of all kinds. This property is shared by the cysts and membranous coatings of all low organisms in the resting-stage, and by the seeds of plants. A resting-stage of long duration is indeed inconceivable without some such protection. In plant seeds and algal spores the impermeability is caused by the deposition in the membrane of fats and resinous bodies, and possibly the spore wall in bacteria is protected in the same way. Another cause of the durability of spores is the density of the protoplasm, which contains less water than it does in the vegetative cell.

The great efficacy of corrosive sublimate as a disinfectant seems at first 
sight to be only a special case of the toxicity of all mercury salts, and formerly it was thought that they were equally poisonous if only equal amounts of the metal were present. Equimolecular solutions therefore were supposed to be necessarily of cqual disinfectant power. Recent investigations, however (55), based upon the modern theory of solutions, have proved this to be wrong, and rendered it probable that the toxicity of a poisonous salt varies with the degree of dissociation. The dissociation theory (56) has shown that in a solution of a salt there are present not only the unaltered molecules of the dissolved substance, but also a certain number of disintegrated or 'dissociated ' molecules. In a solution of $\mathrm{HgCl}_{2}$, for instance, a certain proportion of the $\mathrm{HgCl}_{2}$ molecules are split up into their electrically active components or 'ions,' the positive metallic ions (kations) $\mathrm{Hg}$, and the negative ions (anions) Cl. The degree of dissociation, that is to say, the proportion of dissociated molecules to unchanged $\mathrm{Hg} \mathrm{Cl}_{2}$ molecules, changes with the concentration of the solution, the temperature, and other conditions, and different salts of the same metal are dissociated in different degrees. Now many of the physical properties of a solution, such as electrical conductivity, freezing-point, boiling-point, and osmotic pressure, depend upon the degree of dissociation, and it seems very probable that toxicity does also. Since different salts of mercury are very differently dissociated in watery solutions, we might expect that their toxic powers would be different also, and as a matter of fact we find this to be the case. A sixteen-litre solution ( $\mathrm{I} \cdot 5^{8}$ per cent.) of mercury cyanide, a salt which is but very slightly dissociated, does not kill staphylococci in three minutes, whilst a solution of corrosive sublimate only a quarter the strength (i. e. sixty-four litres, 0.4 per cent.) does. Anthrax spores left for twenty minutes in this solution of sublimate were almost all killed (seven colonies grew), whilst after a sixtcen-litre solution of the cyanide, acting for the same timc, innumerable colonies sprang up.

A comparison of differently dissociated mercury salts shows clearly, thercfore, the relation between dissociation and toxicity. The connexion becomes more striking still when we compare the same salt in different degrees of dissociation.

The proportion of the dissociated molecules to the unaltered molecules in a given solution of a salt is constant. For example in a solution of $\mathrm{HgCl}_{2}$, the proportion of $\mathrm{Cl}$ ions to unchanged $\mathrm{Hg} \mathrm{Cl}_{2}$ molecules is constant. $\mathrm{By}$ adding other chlorine ions, for instance by adding the more strongly dissosociated $\mathrm{NaCl}$, the number of dissociated $\mathrm{Hg} \mathrm{Cl}_{2}$ molecules can be reduced, the reduction being dependent on the ratio between the amounts of dissociation of $\mathrm{HgCl}_{2}$ and of $\mathrm{NaCl}$. Let us suppose a sixtcen-litre solution of $\mathrm{Hg} \mathrm{Cl}_{2}$ to contain $x \mathrm{Cl}$ ions and $y$ unchanged molecules, then, broadly speaking, $\frac{x}{y}=c$ (a constant). If, now, there be added cnough solid $\mathrm{NaCl}$, 
which is more readily dissociated than $\mathrm{Hg} \mathrm{Cl}_{2}$, to make a sixtcen-litre solution, there will be present $x+m \mathrm{Cl}$ ions derived from the $\mathrm{NaCl}$. For the pure $\mathrm{HgCl}_{2}$ solution $x=c y$, but for the $\mathrm{HgCl}_{2}$ plus $\mathrm{NaCl}$ solution $x+(x+m)=c y$ or $x=\frac{c y-m}{2}$. In other words, the number of $\mathrm{Cl}$ ions derived from the $\mathrm{Hg} \mathrm{Cl}_{2}$ is reduced, its degree of dissociation is lessened, and some of the free $\mathrm{Hg}$ and $\mathrm{Cl}$ ions are built up again into complete molecules. The following table shows that as the degree of dissociation is lessened the toxicity is reduced. The figures give the numbers of colonies that arose from approximately equal quantities of spores after these had lain for six minutes in the solutions (55).

\section{Number of Colonies.}

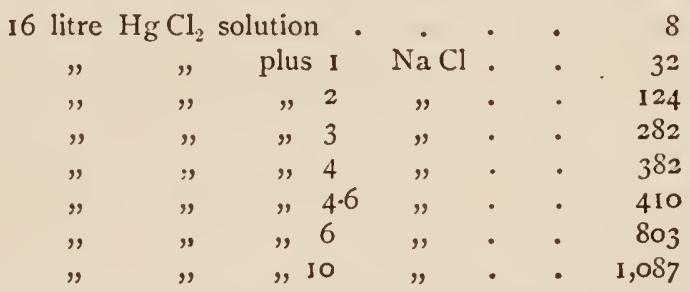

The gradual diminution in germicidal power is unmistakable and needs no comment.

These facts must be borne in mind in experiments on the disinfection, by sublimate, of liquids such as serum or bouillon which contain 0.7 per cent. (eight litres) of $\mathrm{NaCl}$. It is evident that more sublimate will be necessary than in fluids free from salt. The presence of peptone or albumen will necessitate a still further addition of sublimate, because some of it will form insoluble compounds with the proteids whereby its toxicity will be reduced.

Since the degree of dissociation is dependent upon the nature of the solvent and also upon the temperature of the solution, these factors are of influence on the disinfecting power. The increase of toxicity which accompanies increased temperature is not, however, solely the effect of augmented dissociation.

Although the technique of disinfection has not as yet been affected by these recent discoveries, it does not need much penetration to see their high scientific interest and importance.

There are many other bodies besides those mentioned that could be used for disinfecting purposes-anilin dyes, such as methyl violet, ethereal oils, and many aromatic compounds. New disinfectants spring up every day, and are widely advertised, only to disappear again very soon.

Gases, such as carbonic acid, carbonic oxide, hydrogen, nitrous oxidc, nitric oxide, sulphuretted hydrogen, sulphurous acid, and coal gas, arrest the growth of bacteria in agar cultures exposed to a slow stream of the gas, but the method has no practical valuc. The ozone in the air, too, 
even where most abundant, is in such minute quantities as to be quite without influence.

The fact that thousands of bacteria pass through our digestive organs every day suggests the question whether any of the digestive secretions function as natural disinfectants. The saliva and the pancreatic juice are alkaline in reaction and unable to injure bacteria. The pancreatic juice, by reason of the proteids it contains, is even nutritious. The bile acids inhibit the growth of bacteria, but of all the digestive secretions the free acid of the gastric juice $(2-3$ per thousand $\mathrm{H} \mathrm{Cl}$ ) alone is able to kill them. The action of this even is in any case uncertain, and can only affect sporeless cells. Normal gastric juice in a test tube destroys in half an hour the bacteria of cholcra, typhoid and glanders, pus cocci, and the sporeless cclls of anthrax and tetanus (57), but spores are not injured by passing through the stomach. To destroy anthrax spores, they must lie for six hours in 2 per cent. $\mathrm{H} \mathrm{Cl}$, so that it is evident the gastric secretion with only from $\cdot 2$ to .3 per cent. $\mathrm{H} \mathrm{Cl}$ is quite inadequate, even if allowed to act for days. Even against sporeless bacteria it is of little effect, as the examples quoted show. Bacteria given to animals in their food (B. pyocyaneus, blood infected with anthrax, tuberculous tissues) are not entirely destroyed even after six or eight hours (58).

Chemical disinfection of the diseased body is not possible, for the tissue cells would be just as much injured by the disinfectant as the bacteria. Nor is it possible to disinfect by chemical means wounds in which bacteria have taken up their abode; an antisepsis of wounds is not possible. When a wound cannot be purified by mechanical means the body must be helped to fight against the invaders, and the only way to do this is to secure clcanlincss, asepsis. Asepsis confines itself to the treatment of wounds with germ-free instruments and dressings without using chemical disinfectants, and is sufficient to prevent clean fresh wounds, such as are made at operations, from becoming infected.

As to the cause of the fatal action of disinfectants upon the bacteria we know but littlc. We know that the salts of the heavy metals, corrosive sublimate or nitrate of silver for instance, coagulate protoplasm. They destroy life probably by precipitating certain substances from the extremely complex protoplasm of the cells. Other compounds, such as alkalies and acids, may perhaps act by the separation and solution of proteid bodies, resulting in a destruction of the protoplasmic structure. Even a change in reaction might cause the precipitation of certain constituents. In most cases, however, the matter is beyond any explanation, because we have no knowledge of the peculiarities of protoplasmic structure on which the phenomena of life depend. 


\section{CHAPTER $\mathrm{X}$}

\section{BACTERIA AND THE CIRCULATION OF NITROGEN IN NATURE}

1. Introduction: The Assimilation of Free Nitrogen by the Bacteria of the Root Nodules of Leguminous Plants, and by Bacteria in the Soil.

APART from the activity of organisms like the pigment and phosphorescent bacteria, and the remarkable metabolism of the sulphur- and iron-bacteria, the work of bacteria in nature embraces three great processes:

I. The circulation of nitrogen: effected by putrefaction, the formation of nitrates, and the assimilation of atmospheric nitrogen.

2. The circulation of carbon by the 'fermentation' of carbohydrates and other nonnitrogenous products of animals and plants. animals.

3. The causation of disease in other organisms, particularly in man and the higher

There are in nature five sources of nitrogen open to plants and animals:

I. The atmosphere (79 per cent. by volume of free nitrogen).

2. The nitrates of the soil and the traces of nitrous acid formed in the air during thunderstorms.

3. Ammonia, which occurs in minute quantities in the air, and is set free abundantly by the putrefaction and decay of dead organisms.

4. Animal excreta, which contain nitrogen compounds of many kinds, even down to ammonia; and

5. The tissues of plants and animals.

The first three of the above-named sources are useless to animals, for these obtain their nitrogen from plants only, either directly (herbivora), or indirectly through other animals (carnivora). To plants, on the other hand, nitrogen seemed until comparatively recently to be available only in one of these three forms. Vegetable physiologists had come to the conclusion that in nature the nitrates of the soil were the one and only form in which nitrogen was taken up by plants. For, although it was known that in experiments plants could be got to take up ammonia salts and even gaseous ammonia, it was evident that ammonia was not a common source of nitrogen in nature. And, finally, the atmosphere, the greatest storehouse of nitrogen in nature, seemed closed to plants. These views, however, were overturned by 
detailed investigations into the nutrition of the Leguminosac. That the Leguminosac could grow in soil poor in nitrogen and thrive thereon, even without nitrogenous manuring, had long been known, and it has now been demonstrated that they take up nitrogen from the air (59) and convey it to the soil. This enrichment is particularly evident when the plants are ploughed in. All other plants, all our cereals and food crops, are, as regards the soil, merely consumers of nitrogen, since they are unable to take it up in any form but that of the nitrates of the soil.

The difference is seen even in the amount of nitrogen present in the tissues of the two groups of plants. Lupine seeds contain 5.7 per cent. N, wheat grains only 2.I per cent., lupine haulms 0.94 per cent., wheat straw only 0.5 per cent. An experiment with peas showed that a quantity containing I $6 \mathrm{mgr}$. of nitrogen gave rise to a crop containing $499 \mathrm{mgr}$., whilst the quantity of nitrogen in the 4 kilograms of mould they grew in had increased from 22 to 57 milligrams; a total gain of $518 \mathrm{mgr}$. of nitrogen. Calculated for larger quantities of plants it will be at once seen that these figures represent an enormous profit. One hectare $(=2.4$ acres $)$ of lupines is calculated to enrich the earth by 227 kilograms of nitrogen annually. The amount gained by the meteoric fixation of nitrogen (production of $\mathrm{HNO}_{2}$ and $\mathrm{HNO}_{3}$ during thunderstorms) would for the same area be only 0.09 to 1.8 kilogram per annum, so that there is no doubt that it is the atmosphere, and the atmosphere alone, from which these plants cxtract the gas.

Seeing that no other cultivated plants * (not even Brassica alba, the White Mustard) are able to act in this way, we apparently have in the Leguminosae a remarkable and unique group of organisms. But we shall be wrong if we attribute the power of fixing free nitrogen to the tissues of the plant itself. They are powerless to do this, and behave towards nitrogen in no way differently from the tissues of non-leguminous plants. Not until they enter into partnership with certain bacteria, the bacteria of the rootnodules, do the plants act as usurers of nitrogen, gathering and storing it and growing ever richer. The nodules (60) which arise upon the roots of the seedling plants when they are a few weeks old are minute white or pinkish excrescences that soon increase in size and sometimes give the roots a distorted appearance, as though they were attacked by galls (Fig. I 9, $a$ and $b$ ). At first hard and smooth, they become wrinkled as the foliage of the plant grows and, by the time the pods are ripe, are shrivelled and cracked. Their dried remains rot in the ground with the rest of the root. The nodules are either separate excrescences on the surface of the root, with whose vessels they are connected by a tiny strand of vascular fibres, or the root itself swells up in places. In both cases there is always a close connexion between the cells of the nodule and the conductive tissue of the

* The nodule-bearing alder and Elaeagnus are perhaps exceptions. 
plant (Fig. I 9, b). If a transverse section of a young and firm nodule, which exudes a turbid milky juice on crushing, be examined, masses of large cells are seen, distinguished from those that surround them by being filled with a finely striate or punctate mass. Sometimes there are numerous small nests of cells, sometimes they run together to form larger masses. These cells, which constitute what was formerly known as the 'bacteroidal tiss $e$ ' (Fig. I $9, b$ and $c$ ), are nothing more or less than the enlarged cells of the root itself crammed full of fine, slender, rod-shaped bodies (Fig. 19d). The nature

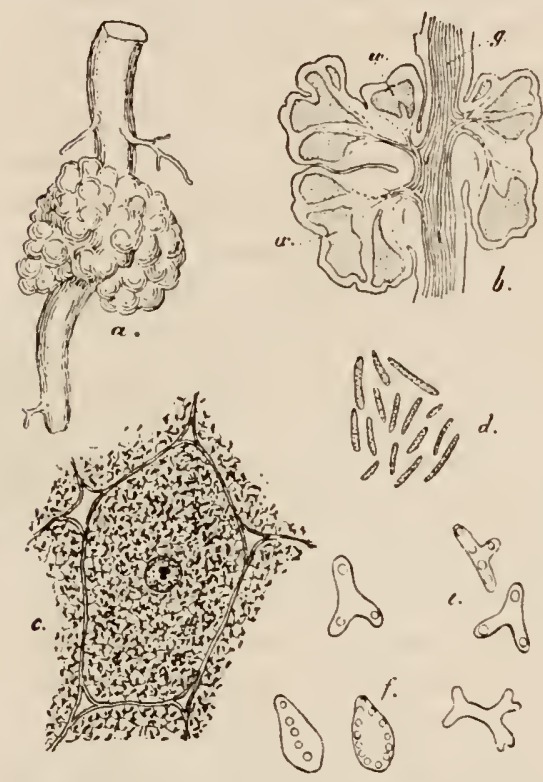

Fig. 10. Root-nodules of Leguminosae. $a$, root nodule of the lupine, nat. size (from Woronin); $b$, longitudinal section through a lupine ront and nodule; $g$, fibro-vascular bundle of root giving off fine branches to every part of the nodule, and its bacteroidal tissue (w), (low power, from Woronin); $c$, a cell from a lupine nodule filled with bacteria (black) between which the finer stroma of the protoplasm is visible; at the angles of the cells intercellular spaces; from a section (fixed with Fleming's solution, stained by Gram's method). $d$, bacteria from root nodule of lupine, normal undegenerate form; $e$ and $f$, bacteroids from Vicia villosa and Lupinzus albus (from Morck). Magn. $c 600, d-f$ about 1500 . of these has been variously interpreted. Woronin, the first observer (I866), took them to be bacteria-like parasites; other investigators since then have looked upon them as proteid crystals. If this view were correct we should have to regard the rootnodules not as pathological structures, but rather as a kind of nitrogenous potato with the albumen in the form of bacteroids. Recent investigations have, however, placed it beyond dispute that these rod-shaped bodies are bacteria, living and growing in the cells of the root (Fig. I9, $c-f$ ). The normal straight, rod-shaped bacteria, well tingible with anilin colours, are only found in the young nodules. As these grow older the bacteria take on all manner of distorted shapes; spindle-shaped, branched, bifurcated or inflated forms are common. It is to these deformed bacteria only (Fig. I9, $e$ and $f$ ) that the term bacteroids is still applied. They are so-called 'involution forms,' similar to those found among many other species of bacteria when the conditions of growth are unfavourable (the acetic ferment, for instance, or the bacilli in old tubercle or diphtheria cultures). The cell contents as well as the shape are affected. They stain badly, and large numbers of the bacteroids seem to be mere empty shells. The conversion of the bacteria into bacteroids is, in short, nothing but a sign that the micro-organisms are dying and yielding up their protoplasmic contents to the plant, which begins to grow more vigorously as soon as the bacteroids appear. By the time the seed of the plant is ripe the shrunken empty nodules contain only fragments 
of the bacteroids, together with a few intact healthy rods that remain in the soil and serve as seed material for next year's nodules.

Root-nodules have been found in all the sub-orders of the Leguminosac (Papilionaceac, Mimoscac, Cacsalpineac), and they always contain bacteria and bacteroids. Root-nodules without bacteria do not cxist, and since Leguminosae destitute of nodules behave with regard to nitrogen just as other plants do, it scems evident that the bacteria are the nitrogen collectors. As an umproved hypothesis this idea was floating in the air for a long time, until the classical researches of Hellriegel and Wilfahrt (59) placed the matter beyond the reach of controversy. Their experiments proved that it was possible by planting sterilized sceds in sterilized carth to grow leguminous plants for some months without root-nodules, if they were well protected from subscquent infection. They showed further that such plants had lost the power of storing nitrogen, but regained it if the earth they grew in were inoculated with an infusion of soil whercon Leguminosae had previously flourished. Finally their researches brought to light the marked contrast between nitrogen-storers like Leguminosae, and nitrogen-consumers such as wheat or oats. The following table gives a few of the chief results of their investigations.

I. NOT STERILIZED AND NOT INOCUlated:

(a) Without nitrogenous manure

Oats

. . . . . 0.027

Peas . . . . . . . $0.04 \mathrm{I}$

(b) Manured with nitrate of calcium

$(\mathrm{N}=0.112$ grammes)

Oats

\begin{tabular}{|c|c|c|}
\hline $\begin{array}{l}\text { Amount of } \\
\text { Nitrogen in } \\
\text { seed and soil. }\end{array}$ & $\begin{array}{l}\text { Amount of } \\
\text { Nitrogen } \\
\text { in crop. }\end{array}$ & $\begin{array}{l}\text { Gain or Los } \\
\text { of Nitrogen } \\
\text { in crop. }\end{array}$ \\
\hline $\begin{array}{c}\text { Granmes. } \\
0.027 \\
0.041\end{array}$ & $\begin{array}{c}\text { Grammes. } \\
0.007 \\
1.283\end{array}$ & $\begin{array}{c}\text { Grammes. } \\
-0.020 \\
+1.242\end{array}$ \\
\hline $\begin{array}{l}0.139 \\
0.153\end{array}$ & $\begin{array}{l}0.09 \\
0.700\end{array}$ & $\begin{array}{l}-0.049 \\
+0.547\end{array}$ \\
\hline $\begin{array}{l}0.027 \\
0.038\end{array}$ & $\begin{array}{l}0.007 \\
0.459\end{array}$ & $\begin{array}{l}-0.020 \\
+0.421\end{array}$ \\
\hline $\begin{array}{l}0.139 \\
0.150\end{array}$ & $\begin{array}{l}0.088 \\
0.220\end{array}$ & $\begin{array}{l}-0.051 \\
+0.070\end{array}$ \\
\hline $0.03 S$ & $0.01 j$ & -0.023 \\
\hline 0.045 & 0.014 & $-0.03 I$ \\
\hline
\end{tabular}

III. INOCULATED AND STERILIZED:

(a) Without nitrogenous manure

(b) With nitrate of calcium Peas

( $N=0.112$ grammes)

Peas 
These tables explain themselves. It is clear that the pea nourishes itself in a similar manner to the oat when cultivated in sterilized soil and unable to form nodules (III), whereas under natural conditions it bears these prolifically and stores up nitrogen in large quantities. Furthermore, the tables show that, whilst oats are rendered much richer in nitrogen by suitable manuring (I $b$ and II $b$ ), peas are not affected (III); they cannot utilize nitrogen offered to them in this form. For oats, on the other hand, it is a matter of indifference whether the soil is sterilized or not, since they form no nodules. The advantage gained from non-nitrogenous manure, such as phosphate of potash, is shared equally by oats and peas.

The next task was to obtain pure cultures of the bacteria of the rootnodules, and ascertain their behaviour towards atmospheric nitrogen. They are easy to cultivate on a decoction of leguminous plants to which $\frac{1}{2}$ per cent. asparagin and 2 per cent. sugar has been added. In such a medium the bacteria grow well in the form of slender rods, aerobic and mobile, with a tendency to produce involution forms or bacteroids. They at first get their nitrogen from the asparagin, but after about two months' growth every litre of the culture has gained from 9 to 18 milligrams of nitrogen which must necessarily have come from the atmosphere (Beyerinck). Mazé in similar experiments obtained an increase of $47.5 \mathrm{mgr}$. nitrogen in fifteen days, and in another case $23.4 \mathrm{mgr}$. in eighteen days, so that although further investigations are desirable there can be no doubt that pure cultures of the bacteria from root-nodules do actually assimilate and fix the nitrogen of the air (61).

Morphologically the bacteria from different kinds of Leguminosae, whether in the nodules themselves or in pure culture, are very similar in appearance, and the growths on gelatine (which is not liquefied) are all of the same character. The 'bacteroid' forms are likewise of the same kind in all cases, so that it would seem as if all Leguminosae were inhabited by the same species of bacterium, to which the name Bacillus radicicola was given by Beyerinck and Rhizobium leguminosarum by Frank. But as soon as we investigate the action of these bacteria upon plants we find differences between them.

If plants of clover, pea, and vetch growing in sterilized earth and destitute of root-nodules be watered with an infusion of bacteria derived from the root-nodules of peas, we find that numerous root-nodules arise both on the pea and on the vetch, whilst the clover forms very few or none at all. Conversely, clover bacteria are almost useless to the pea and the vetch. Nobbe and Hiltner (62) as a result of experiments, which although successful are not beyond criticism, have come to the conclusion that it is only between members of the same group of Papilionaceae that the bacteria of the root-nodules are exchangeable, that, for instance, clover bacteria can be used by other Trifolieae such as lucerne, but not by Phascolus lupines 
or other Phascoleae or by Viciae such as Vicia, Ervum, or Pisum, the bacteria of these again being useless to Trifolicac. We should have, in fact, if these views be correct, different breeds of one and the same species of bacterium (B. radicicola), comparable to the different races of brewers' yeasts or to those described by Eriksson in the wheat rust-fungus Puccinia.

Nobbe and Hiltner have attempted to turn their improved theories to practical account by the introduction of 'Nitragin,' a preparation manufactured at the Höchst Chemical Works. Nitragin is a pure culture on gelatine of bacteria from root-nodules-a kind of living manure to be mixed with the seed matcrial or soil and strewn over the fields. There are eight different sorts of nitragin on the market, suitable for peas, lupines, beans, \&c., and it is said to be very advantageous when first planting Leguminosae in virgin soil, or in soil of poor quality, moors for instance, or where for many years no Leguminosae have grown and the land is presumably destitute of nodule organisms. The results are extremely inconstant and frequently very difficult to judge, so that it is not surprising that opinions are divided as to its efficacy $*$. Instead of nitragin, 'leguminous earth,' i.e. soil in which Leguminosae thrive well, is sometimes used with advantage to 'inoculate' new ground and bad earth such as moorland.

The remarkable association of bacteria with leguminous plants is generally regarded as an instance of symbiosis, a connexion from which both parties reap advantage similar to the 'mutual' association of alga and fungus in lichens. Here, as is well known, the green or brown cells of

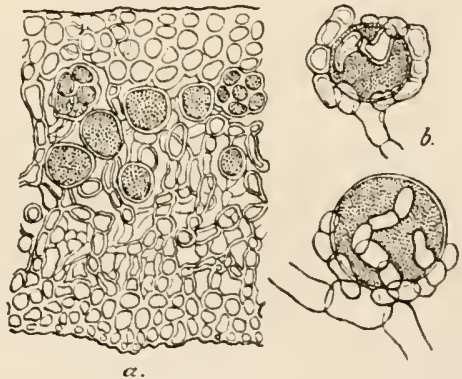

FIG. 20. Parasitism of Lichens. $a$, section through the thallus of Xanthoria parietina (from Schwendener); $b$, algal cells surrounded by fine fungous hyphae in Cladonia furcala (from Bornet). The green algae dotted black. Magn. a 500, b 950. the alga are enclosed by the thickly matted filaments of the fungus (Fig. 20). The alga supplies the metatrophic fungus with organic compounds and the fungus repays the debt by providing the alga with the necessary moisture and mineral salts, not to speak of the protection that its embrace involves. This at least is the opinion of those who, following the 'symbiotic' tendency of the day, look upon a lichen as a co-operative concern. But it is more than doubtful whether this view is correct. All the algae that live in lichens are known to be able to live in a free state. They certainly do not need to be supplied by the fungus with water and mineral salts, and as regards protection it is difficult to see how the algal cells can be 'protected' by hyphac which cling round them tightly and send 'suckers' into their interior (Fig. 20,b). The fungus behaves in every way as a parasite which lives upon

* [See Dawson, Phil. Trans. 1899, Vol. 192, pp. 1-2S.] 
the alga. As a parasite it must establish a close connexion between its tissues and those of its host, and, since it cannot crawl into the alga as the tape-worm does into man, it winds its hyphae around the cells. Enclosed thus in the light, well-ventilated thallus of the fungus, the algae continue to live, but they draw no nourishment from it. The advantage is entirely on the side of the fungus, which is a true parasite.

The association between the leguminous plants and the bacteria of their root-nodules, paradoxical as it appears at first sight, is of a precisely similar character; the plant is parasitic upon the micro-organism. To render this view more comprehensible, we will consider in detail the development of the nodules. The fine root-hairs of a young leguminous plant, destitute as yet of nodules, push themselves everywhere into the crannies between the particles of soil, taking up water and mineral salts and

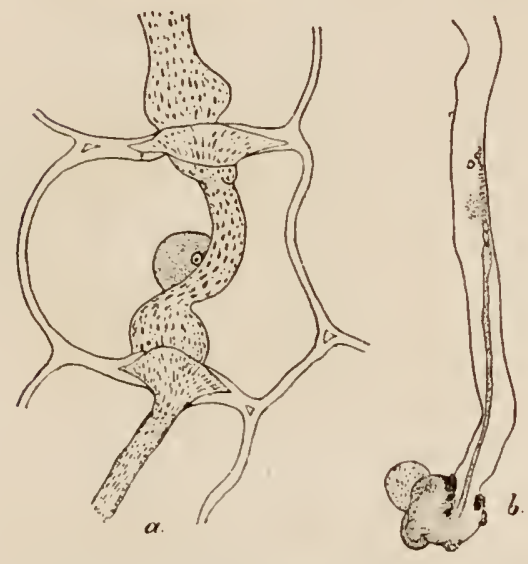

FIG. 2I. Invasion of leguminous roots by bacteria. $a$. Cell from the integument of root of the pea with nucleus and so-called 'infection thread,' a broad stream of bacteria zoogloea that pushes its way through the cell walls (from Prazmow'ski); $b$, end of a root-hair of the pea ; at the right, particles of earth, and on the left a mass of bacteria have gathered. Inside the hair, protoplasm mixed with bacteria which are pushing their way in a thin stream upward. (From B. Frank.) secreting fluids which dissolve and render assimilable the substances with which the cell-wall comes into contact. There can be no doubt that some of the secretions of the root-hairs act chemotactically upon many of the bacteria that swim in the water-filled crevices of the soil; and these would be attracted furthermore by organic substances issuing from wounds or scratches upon the root-hairs or upon the epidermis of the root. Asparagin, one of the most powerfully chemotactic compounds known, is present in large quantities in the tissues of germinating plants, and must necessarily escape wherever the cell-walls are injured. It is quite possible that this substance acts as a 'bait' to attract the bacteria which would swarm into a torn roothair just as they do into a capillary filled with asparagin (Fig. 2I, b). There are reasons, too, for thinking that the plant facilitates the entrance of the micro-organisms by a softening of the cell-membrane of the root-hairs. This much is certain, that the bacteria are chemotactically attracted to the plant, and that, nourished by the organic substances offered to them, they multiply rapidly and force their way from the surface of the root inwards. Here again by softening its cell-walls the plant seems to smooth their path, and in thick columns the bacteria zoogloea* pushes on from cell to cell

* The so-called 'infection-thread,' first observed penetrating the root-hairs by Marshall Ward (see Phil. Trans. 1887, Vol. 178, p. 545). 
into the inner tissues of the root (Fig. $2 \mathrm{I}, a \& b$ ). And now the plant begins visibly to react to the stimulus. Many of the cells of the root become larger, and carbohydrates and asparagin are brought down from the upper parts of the plant to be given unstintingly to the micro-organisms, whose accelerated growth and multiplication soon become manifest in the fast developing nodules. The root-nodules are nothing else than pure cultures of bacteria maintained by the plant for its own ends. The microbes, which grow at first at the expense of the tissues they live in, become before long more independent and draw their nitrogen from the atmospherc. Carbon they most likely obtain the whole summer through from the plant, which probably also secretes the ferment by which the starch is changed into assimilable sugar.

The root-nodules are now in full activity, the bacteria in the cells absorbing nitrogen from the air in the intercellular spaces (63), and storing it up in their own bodies. But this state of exuberant vitality does not last. From overcrowding and other causes the multiplication of the bacteria becomes less rapid and bacteroids (involution forms) appear, a sign that the conditions of life are becoming less favourable. The plant asserts itself, and begins to absorb the substance of the bacterial cells, conveying the nitrogen from the root-nodules into the growing seeds. In the lupine at the time of flowering the nodules contain 5.2 per cent. $\mathrm{N}$, which then becomes gradually less until, by the time the pods are ripe, only $\mathrm{I} \cdot 7$ per cent. is present. It is the nodules alone which yield up their nitrogen in this way, the amount contained in the other parts of the root remaining from first to last unchanged, namely about $\mathrm{I} \cdot 6$ per cent. The precise way in which the leguminous plant absorbs the bacterial cells is not clearly understood, but in all probability it dissolves them by means of a peptonizing enzyme. Only a remnant of the bacteria return to the soil when the root decays, the greater number are literally eaten up by the plant. To call this symbiosis is certainly a misapplication of the term*. The carbohydrates and asparagin that the plant offers the bacteria in the beginning are nothing but a usurer's loan, for in the shape of valuable nitrogen they are demanded back again later on. with heavy interest. Looked at from this standpoint, the view that the leguminous plant is parasitic on the bacteria no longer appears absurd. It is obliged to 'put itself outside 'its hosts, just as the fungus is obliged to enclose the algac in the lichen thallus. But, whilst the lichen fungus is completely parasitic, the leguminous plant is only partly so. It only derives its nitrogen from its host, supplying its other needs (carbohydrates, mineral salts, \&c.) in the same way as all ordinary plants, from which it differs indecd only in being unable

* [It should be pointed out that the author's views of the relations between the organisms bere and in the Lichens are not those accepted by botanists generally. See, for example, Pfeffer, Physiology of Planls, Vol. I, Engl. ed., Pp. $3^{6} 4$ and $37^{1 .}$.] 
to assimilate nitrogen from the nitrates in the soil. The table (III) on p. 9I shows this very clearly. In this semi-parasitic mode of life the Leguminosae resemble the Rhinanthaceae, Thesium, and some other green plants, of which the roots graft themselves on to the roots of adjacent plants of other species. These function as hosts, but it is not known what substances they yield up to their parasites.

Since it is evident that the soil of every field in which Leguminosae grow, and probably indeed soil of all kinds, contains the bacteria of rootnodules, attempts have naturally been made to obtain them direct from the soil. Up till now these experiments have not been attended with success, nor is it known whether the bacteria live and multiply in the soil, or whether they exist merely in the form of spores (as yet unknown) which are quickened into life by contact with the roots of leguminous plants.

But although it has been hitherto impossible to isolate the bacteria of root-nodules from soil, Winogradsky has discovered another soil bacterium which fixes atmospheric nitrogen (64). It has been named Clostridium Pasteurianum, and belongs to the group of butyric ferments. It can be isolated in a nutritive solution containing sugar (as a source of carbon) and mineral salts, nitrates or other nitrogen compounds being of course rigidly excluded. The sugar is broken up into butyric, acetic, and carbonic acid, and hydrogen, besides some by-products of uncertain composition, and at the same time nitrogen is taken from the atmosphere and stored up in the body of the cells. The more sugar there is present (i.e. the more energetic the fermentation), the greater is the amount of nitrogen taken up, as the following figures show :

Dextrose in nutritive
solution.
Grammes.
I
2
3
6
N. in nutritive
solution.

$\circ$

o

0

o
N. in the crop
after fermentation.
Milligrammes.

$3 \cdot 0$

$2 \cdot 9$

$8 \cdot \mathrm{I}$

$12 \cdot 8$

Possibly the nitrogen is fixed by nascent hydrogen, and ammonia formed as the first product. The bacterium in pure culture is an anaerobic actively motile bacillus which grows in slimy masses. It is considerably different in appearance from the bacteria of root-nodules, becoming spindleshaped during sporulation (hence the name Clostridium) and, like other butyric bacteria, it stains blue with iodine.

What the conditions are under which Clostridium Pasteurianum exists in nature, and whence it obtains its carbon, is unknown. Should sugar be a necessity it could not grow in unmanured soil, but might occur in situations where the processes of fermentation and putrefaction give rise to a variety of organic compounds. 
It is not known whether other butyric organisms are also able to fix atmospheric nitrogen, but presumably other, perhaps prototrophic, bacteria of the soil do so. It is highly probable that we shall find such in forests where the earth is never 'manured' and where, notwithstanding, enormous quantities of nitrogen are fixed and worked up into the living substance of plants. But all researches in this direction must be received very critically, for there can be no doubt that the idea now very common in agricultural circles that all soil bacteria can assimilate free nitrogen is quite incorrect. Green and blue-green algae were formerly supposed to be able to do so, but this opinion is now held to be incorrect (65), and although it is stated that mould-fungi can fix free nitrogen the experiments on which the statement is based did not take into consideration all the possible sources of error. The time will perhaps come when 'Nitragin' will be replaced by pure cultures of free-living, nitrogen-fixing bacteria, which will be 'sown' so as to alternate with nitrogen-consuming crops. 


\section{CHAPTER XI}

\section{BACTERIA AND THE CIRCULATION OF NITROGEN (Continued)}

\section{The Liberation of Organic Nitrogen by Putrefaction, and its Mineralization by the Nitrifying Bactoria.}

ONE of the most conspicuous physiological differences between plants and animals is the absence in plants of any nitrogen-containing excretions.

Nitrogen, once assimilated by the plant, is built up into proteids, alkaloids, colouring-matters (chlorophyll, indigo), and other compounds, but as long as the plant lives is not excreted. It is set into circulation again only by the death and decay of the tissues, for the living plant can be used as a source of nitrogen only by parasites and by plant-eating animals.

In the animal body nitrogen is present chiefly in the form of proteids and their derivatives the albuminoids, e. g. mucin, glutin, keratin, elastin, as well as other highly complex bodies such as lecithin, haemoglobin, chilin, and nuclein. In the animal, as in the plant, the nitrogen of these substances is set free at death, but, in addition, the animal, unlike the plant, gives off in its secretions (milk) and excretions (dung, urine) a number of nitrogenous compounds. It is to these substances, enriched still more by the nitrogen contained in straw, that stable-manure owes its high value as a fertilizer for plants.

But the nitrogen in fresh stable-manure is in a form that is useless to plants; they cannot assimilate it. In the urine of herbivora nitrogen is present mainly as hippuric acid, in human urine mainly as urea and uric acid. In the excrements it is contained in the remnants of undigested nitrogenous food, and the products of decomposition set up by the bacteria of the intestine. These products include indol, skatol, leucin, tyrosin, and many simpler nitrogen compounds even down to ammonia. But none of these, not even ammonia, are directly available as nutritive materials for green plants. Not until the nitrogen has been removed from the organic molecule by the process of putrefaction, and has been united to a mineral base by the process of nitrification, can it be taken up by the green plant. 
'Thrnugh the tissues of green plants all organic nitrogen inust, however, sooner or later, circulate.

Putrefaction is a purely biochemical process, and can only take place when the fundamental conditions for all vital action are fulfilled. If the temperature sink below a certain point, organic substances cannot putrefy, as was well shown by the frozen Siberian mammoths. When discovered, their flesh was so little changed that it was eaten by the hunters' dogs ; yet it must have lain in Nature's refrigators for countless centuries. Absence of moisture acts in the same way as absence of warmth. Dry meat does not putrefy. Dryness and a low temperature together will preserve organic matter for any length of time, as is well illustrated by the undecayed yet unembalmed bodies that have been kept for centuries in the vaults of certain churches. Other means of preservation by chemical and physical agencies have been already referred to, but in all methods the fundamental principle is the same, namely, to create such conditions that bacteria cannot live; for putrefaction-the splitting-up of the nitrogenous constituents of organic matter-is the work of bacteria, and of bacteria alone.

The flèsh of fruits, being poor in nitrogen and rich in organic acids, is not attacked by bacteria. The rotting of pears, grapes, oranges, and other fruits of a like character, is brought about principally by mould-fungi (66) (Penicillinm, MTucor, Botrytis).

The decomposition of dead animal bodies, of vegetable tissues, or of substances like stable-manure, is far from being a simple putrcfactive process. Side by side with the disintegration of nitrogenous bodies there are going on a number of fermentative changes by which non-nitrogenous compounds are being broken up, besides nitrification and other biochemical processes. For this reason it is always difficult, and often impossible, to determine the respective parts played by the different species of bacteria. Putrefactive processes are going on in all places where nitrogenous organic matter is under suitable conditions of temperature and moisture, manure heaps for instance, cesspools, the muddy bottoms of lakes and rivers, and the ocean floor.

Proteids are split up by putrefaction into a large number of simpler compounds both nitrogenous and non-nitrogenous. The substances thus produced are precisely similar to those resulting from the artificial decomposition of proteids by fusion with caustic potash, or boiling with hydrochloric acid or barium hydrate. Five groups may be distinguished:

I. Albumoses and peptones: soluble diffusible bodies closely resembling albumen. They are produced by the action on albumen of bacterial enzymes similar to the enzymes (pepsin and pancreatin) which give rise to peptones in the digestive tract of man.

2. Aromatic compounds: among others indol and skatol which give the characteristic odour to human excrement; also some non-nitrogenous substances such as phenol, phenylacetic acid, and phenylpropionic acid.

3. Amido compounds, all nitrogenous; leucin, tyrosin, aspartic acid. glycocol. 
4. Fatty and aromatic acids, all non-nitrogenous and therefore having no part in the circulation of nitrogen; acetic, butyric, succinic, and valerianic acids.

5. Inorganic end-products of putrefaction: free nitrogen, ammonia, free hydrogen, methane, carbonic acid, methylmercaptan, sulphuretted hydrogen. It is probable also, but not certain, that phosphuretted hydrogen is formed and is oxidized at once by the free oxygen of the atmosphere.

Most of these substances are formed also by the chemical decomposition of proteids, but there is a sixth group which may be termed specific putrefactive products. These are the so-called ptomaines or putrefactive alkaloids (67). They are nitrogenous compounds (amine-bases), but although a large number have been described they are, in consequence of the difficulty of preparing them, still only imperfectly known. From putrid flesh (mammalian, including human), fish, and gelatine Brieger isolated neuridine $\left(\mathrm{C}_{5} \mathrm{H}_{34} \mathrm{~N}_{2}\right.$ ), trimethylamine $\left(\mathrm{C}_{3} \mathrm{H}_{9} \mathrm{~N}\right.$ ), cadaverine (pentamethylendiamine, $\mathrm{C}_{5} \mathrm{H}_{14} \mathrm{~N}_{2}$ ), and putrescine, a diamine of the methylene series $\left(\mathrm{C}_{4} \mathrm{H}_{12} \mathrm{~N}_{2}\right)$. These are all of them either not poisonous or only poisonous in large doses. Other ptomaines, derived from putrid foods of various kinds (sausages, cheese), are highly toxic (Ptomatropine, Tyrotoxine). The name toxine was formerly used for the amine bases only, but it is now applied indiscriminately to all bacterial poisons irrespectively of their chemical constitution. (See also Ch. XVII.)

As far as the circulation of nitrogen is concerned, we have to consider only the end-products of putrefaction, free nitrogen and ammonia. All the more complex intermediate bodics are broken down finally to these. Leucin, for instance, splits up into valeric acid, ammonia, carbonic acid, and free hydrogen. Tyrosin yields by aerobic putrefaction hydroparacumaric acid, paraoxyphenylacetic acid, paracresol, phenol, ammonia, and carbonic acid. By anaerobic putrefaction it gives rise to indol, carbonic acid, and hydrogen.

The phenomena of putrefaction are so complicated that we do not know all of the compounds that arise during the process. The course it runs is, however, greatly modified by the presence of oxygen (68).

This list of putrefactive products is far from being complete, for even the qualitative investigation of the processes is still unfinished; quantitative analyses are at present impossible. IVe do not know for instance what determines the predominance of one or the other intermediate product. The effects of the presence of oxygen are somewhat better understood (68). If air have free access, putrefaction may go on without any odour at all, the evil-smelling gases $\left(\mathrm{NH}_{3}\right.$ and $\mathrm{SH}_{2}$ for example) being oxidized at once to form nitrates and sulphates. Aerobic bacteria too, such as the nitre and sulphur bacteria, bring about this mineralization of organic nitrogen. Moreover, when air is circulating freely, there is no accumulation of intermediate products such as skatol or indol. To this kind of aerobic decomposition, proceeding without offensive smell, the term 'decay' may be applied as distinguished from 'putrefaction.' It occurs on the surface of manure-heaps, on the outer surface of carcases, and in well-ventilated soil. 
In anacrobic decomposition (putrefaction proper), as in anacrobic fermentation, the organic molecules are at first only partly disintegrated, intermediate products such as leucine, tyrosinc, skatol, and indol being formed. In the absence of air these accumulate, and hence it is that the putrefaction going on in the mud of ponds or ditches, or inside carcases, is accompanied by such cril odours.

Although the details of the process vary considerably according to the presence or absence of air, the ultiniate products of putrefaction are in both cases the same: namely, free nitrogen, frec hydrogen, ammonia, methanc, carbonic acid, and sulphuretted hydrogen. These also are the end-results of the disintegration of the human body.

The decomposition of plant tissues, poor in nitrogen but containing large quantities of cellulose, gives rise to humin compounds. There can be no doubt that it is a biochemical process, but the nature and functions of the bacteria concerned in it have not yet been carefully studicd (69).

One of the bacteria which was formerly looked upon as a putrefactive organism par excellence was the Bacterium termo. Cohn described under this name a short, oval, actively motile bacillus, slightly fluorescent in cultures (Fig. 22, a). The species is, however, no longer to be identified, for his description would apply to several common forms. As a matter of fact there are many bacteria going by this name which is properly only applicable as a collective designation for motile bacteria in putrescible substrata.

In the rich bacterial flora of a putrescent fluid (70) two distinct biological groups must be distinguished, the saprogenic and the saprophile. To designate all bactcria living upon dead organic matter as saprophytes is insufficient. As we have alrcady seen, the saprogenic bacteria are able, by the chemical ferments they secrete, to break up the molecules of proteids. The saprophile organisms cannot do this, but they find a rich supply of nutriment in the products thus formed. A large number of metatrophic specics are endowed with this faculty, including some pathogenic forms (cholera and typhoid), and water bacteria like Spirillum undula. The sulphur bacteria too must be called saprophile where they form a coating over the rotting vegetation under water, and the nitrifying organisms also when they oxidize the $\mathrm{NH}_{3}$ evolved from decaying organic matter.

The bacteria of the other division, the true saprogenic organisms, include very numerous species, some of which are much better known than others (c.g. Hauser's B. (Proteus vulgaris), but all of which possess the power of breaking up the complex proteid molecule more or less quickly into simpler groups. With the exception of certain toxines in a few cases, specific products which would serve as classificatory characters are not known. Indol, for example, the production of which was once thought to be characteristic of the cholera germ, is produced by all the cholera-like vibrios, as well as by the $B$. coli and other forms (Fig. 22, b). Near to 
these pathological bacteria with saprogenic properties many of the fluorescent and photogenic bacteria would have their place. Bacillus fuorescens liquefaciens, an actively motile aquatic species, breaks down albumen into peptones, fatty acids, and other compounds. One of the bacteria of the intestine, described formerly as Bacillus putrificus coli, yiclds peptones, indol, skatol, amides, and ammonia. Similar to this species in its action on albumens are the toxine-forming B. vulgaris (Proteus vulgaris) and its allies. B. vulgaris makes its appearance almost always in meat infusions exposed to the air. It is a slender $\operatorname{rod} \mathrm{I} \cdot 5-4 \mu$ long by $0.5 \mu$ thick, with a tendency to form chains. It is peritrichous and actively motile (Fig. 22). Closely related to it are a number of forms (Kurth's, $B$. Zopfii, and others),

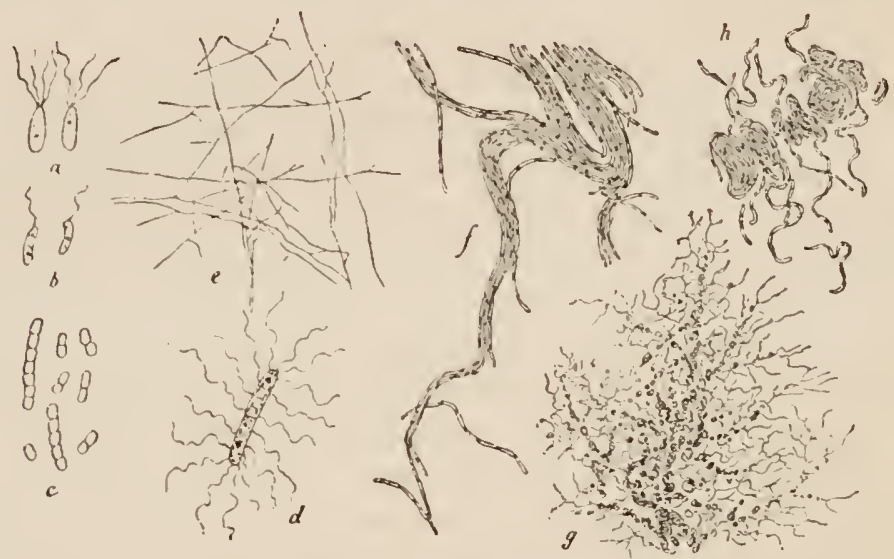

Fig. 22. Putrefactive bacteria. a, Bactrillum pseudotermo, corresponds most closely to the old Bacterium termo of Cohn. $b$. Cholera-like vibrio from putrid water. $c$, Bacillus ureae, the commonest cause of urinous fermentation, probably identical with Pasteur's Micrococcus ureae. d-h, Bactridium Proteus (Bacillus Proteus, Bacterium Zopfii, Proteus vulgaris, \&c.). $d$, peritrichous rod, cobweb-like growth (zoogloea) on gelatine (5o diam.); $f_{\text {. }}$ portion of same more highly magnified ( 300 diam.); $g$, tree-like growth on gelatine with thickenings; $h$, part of same magnified 300 diam. to show the structure of thickenings which consist of closely wound threads. Magn. $a-d$ about $1500, e$ and $g$, $f$ and $h 300$.

all placed at one time by Hauser in one genus Proteus, so called on account of the manifold shapes of their colonies on gelatine*. These colonies are ramified zoogloeae having under a low power much the appearance of fungus mycelia, covering the gelatine with a filamentous growth. Each filament consists of chains of bacteria united by a jelly-like substance (Fig. 22, $d-h$ ):

These apparently specific putrefactive bacteria must not be looked upon as an exclusive group, such as the sulphur or nitrifying organisms, whose metabolism is of a circumscribed kind and which can only thrive when its peculiar conditions can be fulfilled. The various species of Proteus, for instance, have zymogenic as well as saprogenic properties. Thcy can ferment carbohydrates, producing gas and acid during the process, as does also Bacillus coli communis. 
Very carcful chemical investigations on pure cultures will be necessary before the chatos of phenomena presented by the putrefactive bacteria can be arranged in something like order. In view of the present state of our knowledge of these organisms, it will be best perhaps to make the definition of a putrefactive bacterium rather wide, and include all bacteria with saprogenic properties, whether they possess other pleotrophic propertics (e.g. zymogenic) or not. It is certain that many bacteria, almost all the cocci for instance, and many pigment bacteria, are destitute of saprogenic power. Saprogenic bacteria are able to break up albuminous bodies of every kind and of every morphological character, whatever organs of the body they be derived from. The influcnce of these saprogenic properties in the production of discase will be considered later on.

Just as the Bacterium termo was formerly regarded as the only cause of putrefaction, so was the Micrococcus ureae discovered by Pasteur regarded as the specific microbc of urinous fermentation.

Healthy human urine, sterile and acid when passed, becomes sooner or later alkaline. The urea has been converted by addition of water into carbonatc of ammonia :

$$
\mathrm{CO}\left(\mathrm{NH}_{2}\right)_{2}+2 \mathrm{H}_{2} \mathrm{O}=\mathrm{CO}_{3}\left(\mathrm{NH}_{4}\right)_{2} \text {. }
$$

A similar decomposition is undergone by the uric acid and by the hippuric acid in the urine of herbivores. It is caused by a bacterial ferment and, as with the putrefactive organisms, it was formerly thought that one species alone was at work. This was the Micrococcus ureae of Pasteur, a short, almost spherical, non-motile cell generally growing in pairs (Fig. 22) or little chains (71 and 112). We know now, however, that many different kinds of bacteria are able to cause the ammoniacal fermentation of urine. No less than sixty species are said to occur in manure and sewage, among others the B. vulgaris. On the other hand, B. subtilis, B. anthracis, B. typhi, $V$. cholerae, the pus cocci, and many saprogenic forms are unable to split up urea. Conversely, the urea bacteria are incapable of decomposing albuminous bodies, which is not surprising, seeing how different the two processes are chemically.

The resting cclls of the urca bacteria are everywhere present in urinc, manure, earth, air, and dust. All urine that is left exposed to the air is sooner or later attacked by them, and its nitrogenous constituents are converted into ammonium carbonate. In this way the path is prepared for the nitrifying organisms, by which the nitrogen is made ready for renewed circulation through the tissues of green plants.

The amount of nitrogen treated in this way by bacteria is enormous. The sewers of Leipzig discharge every day, in the form of urine, no less than $8,400 \mathrm{lb}$. of nitrogen.

The two great processes, putrefaction and ammoniacal fermentation, are going on in nature uninterruptedly. In the soil, in the mud of lakes and 
rivers, in all the sewers and refuse heaps of human communities, the two classes of micro-organisms are incessantly at work, sometimes alone, sometimes together, and the greater part of all organic nitrogen is sooner or later liberated in the form of ammonia, together with a small amount of free nitrogen*. The free nitrogen is at once utilisable by the root-nodule organisms, and by other bacteria in the soil. The ammonia nitrogen, on the other hand, must be 'mineralized' before it can be used by green plants, must be oxidized and combined with a base to form a nitric salt $\dagger$. This change, known as nitrification, was formerly thought to be a purely chemical phenomenon, the oxidation being presumably effected by the free oxygen of the atmosphere. This view is now known to be incorrect, evidence having gradually accumulated which proves irrefutably the biochemical nature of the process. The bacteria to whose activity it is due defied for many years all attempts at isolation, until Winogradsky, the Russian investigator, succeeded in separating them from the soil and obtaining pure cultures (72). His researches too brought to light the unique fact that the nitrifying bacteria are absolutely prototrophic in their mode of life-and we owe to him glimpses into the conditions of existence among the lowest organisms.

The nitrifying bacteria are everywhere present in the soil of our gardens, fields and meadows, and in the virgin earth of the mountain sides and plains, untiringly at work preparing the food for plants. They have been cultivated by us unconsciously for centuries in the 'saltpetre beds,' where putrescible material (manure and other animal remains-skins, horns, glue \&c.) is mixed with lime and allowed to ferment, and there can be little doubt that the Chilian nitre owes its origin to the action of nitrifying bacteria in a recent geological period. It probably arose from the washing down of saltpetre that had accumulated around putrefying organisms in the rainless regions of the coast.

The isolation of the nitrifying bacteria is not difficult; but rather different methods are necessary from those used for other bacteria. Highly nutritious culture media are useless, for the nitrifying bacteria are prototrophic in the strictest sense of the word. They may be cultivated $c n$ masse by inoculating with a little garden earth the following solution:

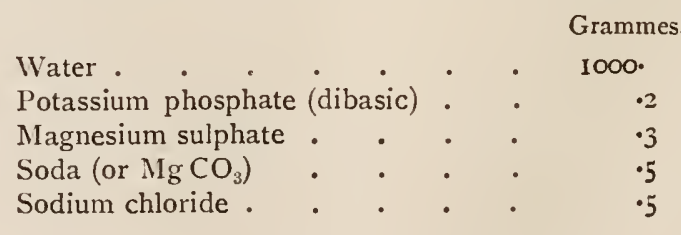

* The nitrogen of crop residues and of the ploughed-in fallow undergoes just the same changes.

+ This applies of course also to the sulphate of ammonia from gas-works, so largely used as manure. 
To these must be added from 20 to $50 \mathrm{mgr}$. of sulphate of ammonia that should be renewed in larger doses ( $1 \mathrm{gr}$.) at intervals of about a week. The only source of nitrogen is the sulphate of ammonia; the carbon is obtained from the $\mathrm{CO}_{2}$ of the atmosphere, not from the sodium or magnesium carbonate, which are added only to neutralize the nitric and nitrous acid that arise from the activity of the bacteria. The sodium chloride benefits them in some way at present unknown.

The nitrogen of the ammonia is not converted directly into nitric acid, as was formerly supposed, but oxidized first of all to nitrous acid and then to nitric. There, are two distinct reactions going on, the formation of nitrites from ammonia, and of nitrates from nitrites. Each is performed by specific bacteria, which are always present together, so that the compounds formed by the one kind are immediately taken up by the other and the end-products alone appear in the soil.

Only in pure cultures is it possible to follow each process separately. Both are very slow; in a sixteen days' old culture, $60 \mathrm{mgr}$. of $\left(\mathrm{NH}_{4}\right)_{2} \mathrm{SO}_{4}$ were converted into nitrous acid daily, and in a six weeks' old culture $64 \mathrm{mgr}$. potassium nitrite daily into nitric acid. Probably, under natural conditions, the process is more rapid.

To isolate the nitrite from the nitrate bacteria, Winogradsky used the customary methods of plate culture, substituting colloid silica for the gelatine*. Very thoroughly washed agar may also be used. For the nitrite organism $\left(\mathrm{NH}_{4}\right)_{2} \mathrm{SO}_{4}$ is added to the medium, for the nitrate bacteria $\mathrm{KNO}_{2}$.

The nitrite bacteria are divided by Winogradsky into two biological genera, Nitrosococcus and Nitrosomonas. Nitrosococcus is

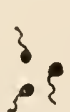

a.
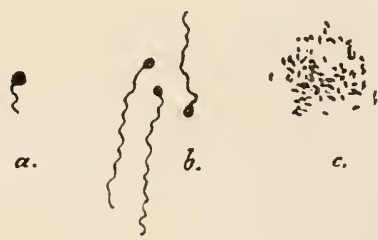

FIG. 23. Nitrifving bacteria (trom Winogradsky). a, Nitrosomonas europen, a nitrite bacterium from Zurich. b, Nitroso. monas javanensis, a similar organism from Java. c, Nitrobacter, a nitrate bacterium from Quito. Magn. Iooo. a non-motile spherical cell $(3 \mu$ in diameter, and less) found in soil from South America and Australia. Nitrosomonas is a very short ellipsoidal, motile form, of which two species in particular may be mentioned. Nitrosomonas curopea (Fig. 23, a), ubiquitous in the soil in Europe, Africa, and Japan, is from $0.9 \mu$ to $1 \mu$ wide, and $1.2 \mu$ to $1.8 \mu$ long, with a short cilium. $N$. javanensis from Buitenzorg (Fig. $23, b$ ) is almost spherical $(0.5-0.6 \mu)$, with a cilium $30 \mu$ long. This is the longest cilium known among bacteria. Spores have not been seen. The nitrite bacteria render the culture turbid as long as they are motile. They also form zooglocae, and if crystals of $\mathrm{Mg} \mathrm{CO}_{3}$ be added the bacteria collect on them in slimy masses and eat into the mineral just as lichens eat into a stone.

\footnotetext{
* For details respeeting the composition of the media, see works eited in Notes (pl. 169-184).
} 
The nitrate bacteria (Nitrobacter, Fig. $23, c$ ) are minute non-motile rods $(0.5 \mu$ by $0.25 \mu)$ that grow without causing turbidity in the medium. They form delicate pellicles on the floor and sides of the culture glass. Spores are unknown.

As might be expected in the case of organisms with oxidizing functions, all the nitrifying bacteria are acrobic. They require no light, and yet in spite of this are able to assimilate the $\mathrm{CO}_{2}$ of the atmosphere. In three experiments, where the nutritive solution contained originally $6 \mathrm{mgr}$. $\mathrm{CO}_{2}$ in the form of $\mathrm{MgCO}_{3}$, the cultures after seven weeks' growth showed $37.6 \mathrm{mgr}$, $26 \mathrm{mgr}$, and $17.5 \mathrm{mgr}$. $\mathrm{CO}_{2}$ respectively. This was subsequently proved by Godlewski (73) to have been absorbed entirely from the air without light and without chlorophyll. As already mentioned, the nitrogen was derived from the ammonia, or from the nitrous acid. A little nitrogen is even set free.

The energy necessary for the processes of life is gained by the nitrifying bacteria from the oxidation of the ammonia, or the nitrous acid. The materials from which they build up their cells are therefore inorganic compounds of the very simplest character, carbon dioxide and ammonia or nitrous acid, with a few mineral salts. They are thus prototrophic in the strictest sense of the word, for a simpler synthesis of proteids than theirs is scarcely conceivable.

Facts have recently come to light which show that green plants do not get the full benefit of all the nitrates formed in the soil by the nitrifying bacteria (74). Nitrate-reducing bacteria have been discovered which destroy that which the nitrifiers have built up. Several species of these denitrifying organisms have been isolated from manure. They grow on a medium containing 0.3 per cent. $\mathrm{Na} \mathrm{NO}_{3}$, sugar, and the necessary salts. Of the nitrogen offered to them, 82.7 per cent. is set free (in some species as much as 99 per cent.), the rest being used up in their cell-substance.

Although it is probable that the importance of these denitrifying organisms in agriculture is very small, it cannot be denied that they occur, and they certainly mar to some extent the clearness of our conception of the processes by which nitrogen circulates through organic creation.

Just as the nitrifying organisms have their converse in the denitrifying, so have the sulphur bacteria theirs in the desulphurizing species. A spirillum ( $S$. desulfuricans) has been isolated from ditches and sewers, which sets free the $\mathrm{SH}_{2}$ from sulphates. The complete life-history of this organism is not known (75).

There can be little doubt that many other biochemical processes are going on in nature besides those we have been considering, and mineralogical chemistry will have to turn its attention to bacteria. Possibly we shall even find prototrophic species which attack silicates. The reader may be left to ponder further on the subject. 


\section{CHAPTER XII}

\section{THE CIRCULATION OF CARBON DIOXIDE IN NATURE}

\section{Introduction; Organized Ferments and Enzymes; Races of Ferment} Organisms; Fermentation of Alcohol and of Acids; Optical Activity and Fermentation.

THE ultimate source, from which dircetly or indirectly all organisms draw their carbon, is the carbonic acid of the atmosphere. In the circulation of this gas bacteria play a not less important part than they do in the circulation of nitrogen. Animals, it is well known, cannot assimilate $\mathrm{CO}_{2}$; they are dependent for their carbon entirely upon plants. Among these again only the chlorophyll-bearing forms and the red, brown, and blue-green algae are able, with the energy of the absorbed sunlight, to fix the atmospheric $\mathrm{CO}_{2}{ }^{*}$. From it the plant builds up the organic compounds, with or without nitrogen, that constitute the physical basis of all life upon the earth. Since this assimilating and fixing of carbonic acid is going on without ceasing, there is an evident nccessity, if terrestrial life is to endure, for the continual return of carbon in the form of $\mathrm{CO}_{2}$ to the atmosphere, and such restitution does as a matter of fact take place. A certain amount is given back at once by the plants themselves in the process of respiration, and another portion is being continually poured out into the air in the breath of man and animals. All the remaining carbon fixed in the tissucs of plants and animals is finally liberated at the death of the organism by the activity of bacteria and other microbes. Those tissue elements which contain nitrogen as well as carbon undergo putrefaction, and the carbon escapes as $\mathrm{CO}_{2}$. The innumcrable non-nitrogenous constituents on the other hand-carbohydrates, glucosides, alcohols, organic acids and fats-are

\footnotetext{
* The prototrophic saltpetre bacteria constitute the sole and only exception to this rule.
} 
not putrescible. They are broken up by 'fermentation,' carbonic acid being again the final shape in which the carbon is set free*.

In nature, fermentative organisms are more widely distributed even than putrefactive. With these they labour to disintegrate and remove dead animals and plants. But in addition to being indispensable scavengers they are of prime importance to man in numerous industries-in the preparation of butter-milk, cheese, 'sauerkraut,' and bread, and in the manufacture of alcohol. Some species, on the other hand, are dangerous enemies to the dairyman and the brewer, and in many technical processes bacteria play a part useful or injurious as the case may be (77).

There is a diversity of opinion as to what shall be understood by the word fermentation. Some would apply it to every kind of chemical change arising from the activity of micro-fungi, and would include putrefaction, nitrification, and the oxidation of $\mathrm{SH}_{2}$ by the thiobacteria, in short all biochemical processes. From this it is but a short step to regard human life itself as a fermentation. In the author's opinion, a more restricted application is desirable, both in view of the history of the word and as inducing to clearness. The word 'fermentation' will therefore be used here to designate the dccomposition by mans of particular living organisms-the formcntation organisms - of non-nitrogcnous organic compounds, particularly carboliydrates.

Given fermentable substances, the necessary conditions for fermentation are a supply of food-stuffs (above all a special source of nitrogen) for the micro-organisms and, as in putrefaction, moisture and a suitable temperature. Even before the nature of fermentation was well understood, we knew that in addition to the fermentable substance a certain something, a ferment, was necessary for the production of the phenomenon, and it was thought by many to be a chemical body. But the classical researches of Pasteur (78) showed that every fermentation was the work of some living organism, a fermcntum vizum, and not of a chemical ferment or enzyme. We have therefore to distinguish between living or organized ferments and unorganized chemical ferments or enzymes. The enzymes (79) are substances secreted by cells (e.g. pancreatin, pepsin, ptyalin), and are capable, even in the absence of the cells that produced them, of causing specific chemical changes in certain organic substances. The organized ferments are living cells. They also are able to set up chemical changes in organic bodies, but only so long as they, the cells, are alive.

Organized ferments and enzymes have much in common. In each case

* In qualification of this somewhat broad statement it should be mentioned that very little is known as yet concerning the biochemical decomposition of fats (76). Preliminary experiments seem to have shown that certain bacteria (cholera, typhoid, B. pyocyaneus) are able to split olive-oil or beef-fat into glycerine and fatty acids, thus making them accessible to fermentation. 
the chemical change produced is specific, is of one kind, and of one kind only. In each case too it is effected apparently without any expenditure of energy, although to produce similar changes in our laboratories we have to resort to very powerful means such as the employment of high temperatures, intense chemical reactions, and, in many cases, we cannot reproduce the changes at all. An instance will make these two points clearer. In plants, starch is converted into sugar by the enzyme diastase without apparent effort, whilst in the laboratory we can only cause this change by boiling with mineral acids. But, whereas boiling with acids will effect very many other changes, diastase is powerless to perform any but the one alteration of starch into sugar. We can convert sugar into lactic acid by heating with alkalies; the lactic bacteria can do the same by their fermentative power, but are unable to produce butyric acid. Some of the biochemical processes of micro-organisms, the conversion of sugar into alcohol for instance, cannot be exactly imitated by chemical means.

Finally, neither enzyme nor organic ferment disappears in effecting such changes, as a reagent disappears in a chemical reaction. There is no definite relation between the quantity of ferment used and the quantity of substance fermented, an enzyme like pepsin, or a yeast, being able to ferment a hundred or a thousand times its own weight of fermentable substance.

The chief and fundamental difference between enzymes and organized ferments lies of course in the fact that the latter are living beings able to grow and multiply, increasing the more rapidly the more food and fermentable material are placed at their disposal. This the enzymes cannot do, for they are lifeless chemical compounds, although they have, it is true, many points of resemblance to the proteids. They are extremely unstable compounds, and when dissolved in water their fermentative power is destroyed by a short exposure to $50^{\circ}-60^{\circ} \mathrm{C}$., just the lethal temperature of most sporeless micro-organisms. But towards protoplasm poisons their behaviour is quite different from that of the organized ferments. Arsenious acid, phenol, salicylic acid, ether, and chloroform in concentrations which paralyze the organized ferments leave the enzymes unaffected. Chloroform however seems to affect some enzymes in a short time.

As regards the nature of the chemical change produced by enzymes and organic ferments respectively, there is a broad and fundamental difference between the two. The enzymes exercise solely a hydrolytic influence. That is to say, they cause the molecules of insoluble compounds to take up water and to separate into less complex molecules of a different constitution, the resultant substances being soluble in water. Diastase, for instance, converts one molecule of starch into one molecule of grape sugar:

$$
\mathrm{C}_{6,} \mathrm{H}_{1,4} \mathrm{O}_{5}+\mathrm{H}_{22} \mathrm{O}=\mathrm{C}_{6} \mathrm{H}_{1,2} \mathrm{O}_{6} \text {. }
$$


In the same way, invertase, an enzyme secreted by yeast cells, converts one molecule of cane sugar into one molecule of glucose and one of fructose:

$$
\mathrm{C}_{12} \mathrm{H}_{22} \mathrm{O}_{11}+\mathrm{H}_{2} \mathrm{O}=\mathrm{C}_{6} \mathrm{H}_{12} \mathrm{O}_{6}+\mathrm{C}_{6} \mathrm{H}_{12} \mathrm{O}_{6} \text {. }
$$

The peptic enzyme (pepsin) of the stomach changes insoluble proteids into soluble peptones and albumoses. All these reactions are complete in themsclves, and there are no by-products such as $\mathrm{CO}_{2}$ or other gascs. The action of organized ferments is quite different. By them the highly complex molecules of organic compounds are split up, and numerous substances of a totally different character arise, generally with the evolution of gases and other by-products. For this reason it is impossible to represent the reaction by a simple chemical equation. Ordinary alcoholic fermentation, for instance, cannot be written

$$
\mathrm{C}_{6} \mathrm{H}_{12} \mathrm{O}_{6}=2 \mathrm{C}_{2} \mathrm{H}_{6} \mathrm{O}+2 \mathrm{CO}_{2} ;
$$

nor butyric fermentation,

$$
\mathrm{C}_{6} \mathrm{H}_{12} \mathrm{O}_{6}=\mathrm{C}_{4} \mathrm{H}_{8} \mathrm{O}_{2}+{ }_{2} \mathrm{CO}_{2}+4 \mathrm{H}
$$

for, as we shall see presently, numerous other compounds are formed.

Carbonic acid being evolved in almost all instances, it is customary to designate each process by the name of some other conspicuous product, as the preceding examples show. A by-product of one kind of fermentation may be the chief product of another kind. Acetic acid, for instance, is a by-product of alcoholic fermentation, but the principal substance formed in vinegar fermentation.

The organized ferments are often regarded as comprising three classes of micro-organisms,-yeasts, bacteria, and moulds. The lastnamed, however, are of rare occurrence, e.g. the mucor yeast that causes the decomposition of wine. The so-called 'aspergillus yeast,' used in China and Japan in the preparation of soy and saké, works only by means of an enzyme that it secretes, the alcohol being produced, not by the aspergillus, but by a true yeast. Similarly in ragi, the 'yeast' of the arrack industry, there are present both a true yeast and a mucorine fungus (Rhizopus Oryzae). The function of this latter is to 'invert' the rice starch and make it accessible to the yeast (80).

Mould fungi are sometimes employed on an industrial scale in the preparation of citric acid (81).

The discrimination of the various species of fermentative organisms is of very recent date. When Pasteur first showed that fermentation was the . work of living cells, we had not the technical means which we now possess of distinguishing closely related species from each other. It was sufficient to assume that every fermentation had its own peculiar fungus, a Bacterium aceticum in vinegar fermentation, a $B$. butyricum in butyric fermentation, and so forth. In the same way it was not until the publication of Hansen's 
revolutionary investigations on yeasts that many different species of Saccharomyecs were recognized. The Saccharomyecs cercisiac of beer-wort, and the S. cllipsoidens of vinous fermentation, and a few others, were the only species known. To-day the species S. cereasiac is divided into hundreds of 'races' or" varieties, and the same has happened to the wine ferments. In these technical processes, some of which are as old as human culture itself, changes have been going on for thousands of years similar to those changes we have caused artificially and intentionally in our domesticated plants and animals. But while we have no difficulty now in distinguishing from one another the innumerable kinds of cultivated plants, the determination of racial characters among micro-organisms is a task of great difficulty. Morphological data are almost useless, and we have to fall back upon physiological peculiarities such as the degree of warmth required (different optima), the nature and amount of by-products, or the specific fermentative power.

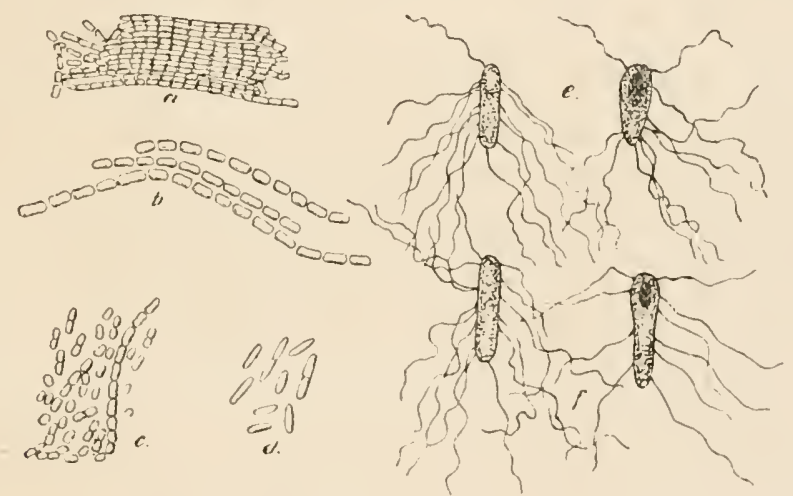

FIG. 24. Fermentation hacteria. $a-c$, acetic bacteria from E. Chr. Hansen. $a$, Bacillus aceti: $b, B$. Pas. teurianus, $c, B$. Kützingianus; $d, B$. acidi lactici, the commonest cause of lactic fermentation; $e$, Clostridium bufyricum, an anaerobic butyric ferment, "granulose 'bearing; to the right spure in spindle-shaped rod. $f$, Plec. rridium paludosum, anaerobic ferment from marsh water, corresponds in form to the methane bacteria, and to some of the butyric bacteria. Magn. $a-f$ row.

Moreover, it must not be forgotten that new varieties are continually arising, old ones dying out and being replaced by others with recently acquired powers. The shortness of the time necessary for the production of a new race of organisms is shown by such plants as the chrysanthemum and the potato. Although the culture of the potato is only two or three hundred years old, there are no less than five hundred varieties in existence, distinguished by shape and colour, by their flavour, by the relative amount of albumen and starch, and other points. Among bacteria, too, there are forms that, like the yeasts, have been cultivated from time immemorial-in cheese-making, for instance, and in vinegar fermentation. These are now cultivated in pure form in our laboratories.

The difficulty of classification among micro-organisms is further increased by the fact that many morphologically different species possess 
similar zymogenic powers. There are a dozen different species of bacteria that produce butyric acid and lactic acid. And, inasmuch as the descriptions given are often far from exact, the student of these species finds himself lost in a pathless forest of forms. For this reason it will be impossible here to describe more than a few species.

Some of the fermentation bacteria can acquire pathogenic properties. Two of the butyric ferments found in soil are known to be the cause of disease, Bacillus Chauroci giving rise to 'quarter-evil' in cattle, and another form originating malignant oedema. The notorious $B$. coli communis is a ferment organism in so far that it splits up grape sugar into lactic acid, succinic acid, and ethyl and propyl alcohol, carbonic dioxide arising in the process. By far the greater number of ferment organisms are, however, harmless, and, considering the millions we take inside us every day in milk, cheese, and other food, it is satisfactory to know this.

The chemistry of fermentation is clearly understood only in those cases where the process is oxidatory. The acetic fermentation belongs to this category, the alcohol being combined with the oxygen of the air to form aldehyde and water, the aldehyde being further oxidized to acetic acid, and this again, if the process be allowed to go on, burnt up to carbonic acid and water. The changes may be represented by equations thus :

$$
\begin{aligned}
& \mathrm{CH}_{3} \mathrm{CH}_{2} \mathrm{HO}+\mathrm{O}=\mathrm{CH}_{3} \mathrm{COH}+\mathrm{H}_{2} \mathrm{O} \\
& \mathrm{CH}_{3} \mathrm{COH}+\mathrm{O}=\mathrm{CH}_{3} \mathrm{COOH} \\
& \mathrm{CH}_{3} \mathrm{COOH}+4 \mathrm{O}=2 \mathrm{CO}_{2}+2 \mathrm{H}_{2} \mathrm{O}
\end{aligned}
$$

This fermentation is evidently allied to the respiratory process, and the similar oxidatory processes of the nitrifying and sulphur bacteria. It differs from most fermentative changes in the small number of resultant substances, but is, of course, just as much a phase in the circulation of carbon as any of the more complex processes, where large numbers of byproducts arise and obscure our view (see Chap. XIV).

Of the fermentations of monacid alcohols only the acetic fermentation of ethyl alcohol is of industrial importance (82). Alcoholic liquids, such as beer or wine, if left exposed to the air in a warm place acquire a strongly acid reaction, and become covered with a white skin or pellicle. This consists of the 'vinegar bacteria,' which slowly oxidize the alcohol to acetic acid, and finally to $\mathrm{CO}_{2}$ and water. Sometimes the pellicle consists not of bacteria but of a yeast (Mycoderma aceti), which transforms the alcohol at once into $\mathrm{CO}_{2}$ and water without the intermediate stage of acetic acid.

The old form, Bacillus aceti, has been divided by Hansen into three different species, B. aceti, B. Pasteurianus, and B. Kiitzingianus (Fig. 24). All three are morphologically very similar, non-motile medium-sized rods often growing out into chains, of which the pellicle mainly consists. They are unable to grow in fluids containing more than 14 per cent. of alcohol. 
Temperature maxima, and some fine differences of shape, distinguish the three species from one another. $B$. aceti is stained entirely yellow by iodine, but in the two other species the gelatinous mass that holds the cells together in the pellicle takes on a blue tint, the cell remaining yellow. Whether a carbohydrate is present is doubtful, and must remain so as long as we are ignorant of the composition of the cell membrane from whose outer layers, by inhibition of water, the jelly is produced. Cellulose is said not to be present.

The optimum tempcrature for acetic fermentation is $34^{\circ} \mathrm{C}$, the maximum $42^{\circ}$, the minimum $4^{\circ}-7^{\circ}$. Approach to the maximum gives 1 ise in all three species to involution forms (Fig. I $4, c$ and $d$, p. 27). The borders of neighbouring cells become indistinct, the cells themselves swell up to pearor spindle-shaped bodies, and short branches arise on the filaments. Even at the optimal temperature involution forms arise as soon as acetic acid begins to accumulate, and when about I4 per cent. is present all growth stops, and the bacteria dic. As a concrete example (83) of the activity of these bacteria it may be mentioned that B. Pastcurianus in 12.5 c.c. of lager beer $(3.7$ per cent. by volume of alcohol) formed in seven days, at $34^{\circ} \mathrm{C} ., 4.2 \mathrm{grm}$. of acetic acid. The alcohol had disappeared, and the acetic acid was finally oxidized to $\mathrm{CO}_{2}$ and water. In a parallel culture, after twenty-one days, only $0.7 \mathrm{grm}$. acid was present. In the manufacture of acetic acid the process must, of course, be stopped at the proper time in order to prevent loss of acid by further oxidation.

In vinegar factories the so-called vinegar plant consists of a zoogloea mass of acetic bacteria, of which there are doubtless many races.

The usual methods of vinegar-making all aim at bringing the alcoholic fluid as much as possible into contact with the air, either by running it into large vats or by letting it flow over wood-shavings in barrels. These methods originated at a time when the process was supposed to be a purely chemical oxidation effected by the air. But the bacteria lying upon the surface of the shavings are the cause of the change; the free access of air promoting it only because the vitality of the bacteria is increased thereby.

Any alcoholic fluids, such as cider, dilute brandy, or wine, can be used to make vinegar, but the taste varies according to the nature of those constituents of the liquids that remain unaltered by the process.

As a by-product, acetic acid arises in many other fermentations, the vinous, the lactic, and the butyric, for example.

In fluids containing no alcohol, however nutritious these may be, the acetic bacteria cannot thrive. They can make use of ammonia salts as a source of nitrogen, but obtain this element in the liquids used for vinegarmaking from proteid substances. Whether the alcohol is used for respiration only, or whether its carbon is in part seized upon by the bacteria as food, is not known. 
Other fermentations of monacid alcohols have not been described, but there can be little doubt that such occur.

Fermentation of higher alcohols (84) has been observed in the case of a motile bacterium isolated from sheep's dung, Bacillus ethaceticus. A culture of this micro-organism in $60 \mathrm{grm}$. glycerine formed

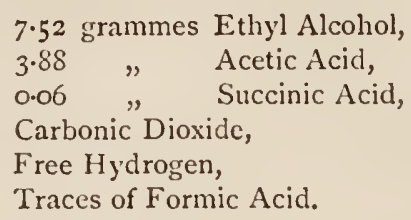

24.19 grm. of glycerine was unchanged. The same bacterium causes similar changes in mannite, but not in its isomer dulcite. The so-called capsule bacillus Pncumococcus of Friedländer ferments mannite also (with the same products), but not dulcite.

Bacillus ethacetosuccinicus (also isolated from dung) ferments both mannite and dulcite. In cultures eighty-five days old that contained, besides the necessary nutriment, eight grams of fermentable substance, there was formed

From Dulcite. From Mannite.

\begin{tabular}{|c|c|c|c|c|c|c|}
\hline Ethyl alcohol & . & • & - & - & 1.011 & 1.03 \\
\hline Formic acid & . & . & - & & 0.128 & $0.26_{3}$ \\
\hline Acetic acid & . & ․ & • & • & 0.322 & 0.308 \\
\hline Succinic acid & . & . & . & . & 0.264 & 0.29 \\
\hline $\mathrm{CO}_{2}$ & . & - & - & - & 1.05 & $1 \cdot 1$ \\
\hline Free $\mathrm{H}$ & . & . & . & . & 0.04 & 0.03 \\
\hline Unfermented & sidue. & . & . & . & 2.62 & $3 \cdot 2$ \\
\hline
\end{tabular}

These figures are of some interest, showing that the chief products are alcohol and carbonic dioxide, and proving that the formation of ethyl alcohol is not a monopoly of the Saccharomyces*.

Glycerine also is capable of fermentation in other ways, butyl alcohol and butyric acid arising among the products (B. orthobutylicus, Chap. XIII).

As examples of the fermentation of fatty and aromatic acids, given in the form of neutral salts, it may be mentioned that acetic acid is oxidized, by the very organisms that produce it, to $\mathrm{CO}_{2}$ and $\mathrm{H}_{2} \mathrm{O}$, and that the dextro-rotatory tartaric acid of wine is converted by various bacteria into formic, acetic, butyric, propionic, lactic, and succinic acids. It is to the activity of such bacteria that the diminution of acidity of wine is due, and probably some of the diseases of wine also. The malic acid in cider is also oxidized by bacteria to acetic, propionic, and butyric acids, carbonic dioxide, and water; and similar processes are known in the case of citric,

* F. Filsianus from hay-infusions also produces ethyl alcohol. 
succinic, and other acids. Lactic acid, itself a product of many carbohydrate fermentations, is converted by butyric bacteria into butyric acid, carbon dioxide, and free hydrogen. The biochemistry of all these processes is as yet but little understood (Chap. XIII).

Very remarkable decompositions of the optically 'inactive' varieties of organic acids are effected by some bacteria*. These consist, as is known, of equal parts of the dextro-rotatory and lacvo-rotatory acids, which twist the plane of polarized light to right and left respectively. In a solution of the ammonium salt of racemic acid, for instance, only the dextro-rotatory variety is used by the bacteria, the lacvo-rotatory modification being thereby as it were set free. The inactive varietics of lactic and mandelic acids are biochemically separable into their components in the same way (85).

The profound chenical disintegration that these changes seem to show is only apparent. As a matter of fact they are only selective changes, only one of the two active compounds of the salt being used up. One of the mucigenous bacteria, for instance, uses up fumaric acid, but leaves the stereo-isomeric compound, maleïc acid, untouched. A similar phenomenon, which may be termed the converse of those just described, is exhibited by a variety of $B$. coli communis which ferments grape sugar into lactic acids differing in rotatory power according to the source of nitrogen employed. If it be supplied with phosphate of ammonia, lacvo-rotatory acid is formed, but if the nitrogen be given to it in the shape of peptone the dextrorotatory variety appears; whereas the lactic acid produced by other fermentations is generally inactive.

We must for the present be content to record these facts-an explanation is not possible. The stereochenical hypotheses, with which modern chemistry seeks to unravel the molecular structure of these isomeric compounds, throw no light whatever at present on the biochemical phenomena associated with them.

* Some of the mould-fungi act in a similar way. 


\section{CHAPTER XIII}

\section{THE CIRCULATION OF CARBON DIOXIDE IN NATURE (continued)}

\section{Bacterial Fermentation of Carbohydrates.}

THE bacteria of lactic fermentation are very widely distributed in nature, and play an important rôle, not only in dairy work, but also in numerous other industrial processes-often as indispensable auxiliarics, but sometimes as dangerous enemics and intruders.

Grape sugar, cane sugar, and milk sugar are all accessible to lactic fermentation. Other sugars (e.g. maltose) are not, nor are carbohydrates like starch or cellulose. All these must be changed into a fermentable form before they can be broken up by the lactic acid bacteria, which themselves produce no such enzymes.

The lactic fermentation is an aerobic process whose optimum lies between $30^{\circ}$ and $35^{\circ} \mathrm{C}$. (for some species between $47^{\circ}$ and $52^{\circ} \mathrm{C}$.). It can go on for a long period only when basic substances, such as calcic carbonate, are present to fix and neutralize the lactic acid as it arises, a very small amount (O.I5 per cent.) of free acid arresting the growth of the bacteria. Eighty per cent. of the fermentable sugar is converted under favourable circumstances into the so-called 'fermentation lactic acid,' optically inactive ethylidene lactic acid, besides which are formed varying amounts of acetic acid, optically active lactic acid, carbon dioxide, and other by-products.

The power of forming lactic acid from sugar is common to many bacteria (e.g. the cholera and most other vibrios, B. prodigiosus, various species from the intestines of infants, and many brewery Sarcinae). But by lactic acid bacteria are generally understood those forms which are the regular cause of the acidification of milk in dairies. These micro-organisms were formerly looked upon as belonging to one species, Bacterium acidi lactici (86), but more recent investigations have shown that not one species but many are at work, sometimes one kind, sometimes another, prevailing. 
A very common form is a short non-motile $\operatorname{rod}(1-2 \mu$ by $0.5 \mu)$, facultatively anacrobic (spores unknown), and not liquefying gelatine (Fig. $24, d$ ). It is known by various names, Bacillus aerogenes, B. acidi lactici, \&rc., and comprises probably several races of one species. They may be called the typical bacteria of lactic fermentation. Mingled with them are found, sometimes in great numbers, the spherical or ovoidal cclls which cause the coagulation of milk. The lactic fermentation of mash in distillerics is caused by yet another form, $B$. acidificans longissimus (87). This bacterium is about $1 \mu$ broad and something more than $2.5 \mu$ long. The number of lactic acid bacteria is great and their determination difficult. The manifold importance of the lactic ferments can be best illustrated by some concrete cxamples.

\section{Milk and other Dairy Products (86), ctc.}

Cow's milk, being neutral or slightly alkaline, and containing as it docs from four to five per cent. of milk sugar, 4 per cent. cascin, and 0.7 per cent. of the necessary mineral salts, is an cxcellent nutritive medium for bacteria. They multiply in it very rapidly, and within a few hours after it is drawn are present in enormous numbers (from 100 to $6,000,000$ per c.c.). As might be expected, the numbers vary grcatly according to the cleanliness of handling during milking and afterwards. In consequence of the favourable conditions thus offered for the multiplication of bactcria, the sterilization of milk, particularly for children, has become a matter of great importance*, and numcrous inventions have been put forward to attain a thorough and efficient sterilization. But milk, although sterile when drawn from the udder, becomes infected with micro-organisms at once on contact with the outside world, and invariably contains sporcbearing bacteria. Some of the spores are so resistant that even boiling for an hour, or an hour and a half in a Soxleth boilcr, does not destroy them, so that at present it scems impossible to render milk absolutely stcrilc without exposing it to heat so great that its chemical characters are altered. Fortunately, the majority of the bacteria in milk are sporeless cells which are killed by boiling for five or ten minutcs, and for this reason cxpensive sterilizing apparatus is being largely discarded in favour of the old domestic method of boiling the milk, and then keeping it as cool as possible, so that the uninjured spores may not germinate (88).

Besides the predominating lactic bacteria, there are always present species that sccrete an cnzyme resembling rennet, and frequently chromogenic forms in small number.

Since the presence of pathogenic germs in milk may become a source

* In Germany a matter of State and municipal control. 
of danger (89), experiments have been made to determine their behaviour in milk. The bacteria of typhoid, anthrax, glanders, tubercle, diphtheria and cholera grow well, without causing any change in the appearance of the milk that would suggest contamination-ordinary market milk does not look as though it contained millions of bacteria-and not until some time has elapsed docs the milk begin to coagulate in conscquence of the acid produced. The anthrax bacillus produces acetic and caproic acids.

Whether the milk of diseased cows contains the specific bactcria of the infection is not certain in all cascs. In tuberculosis, however, tubercle bacilli have been repeatedly found in the milk.

The acidification of milk for the preparation of cheese made from the 'acid curd' is the work of the lactic bacteria already mentioned. The acid they produce precipitates the cascin-the milk 'coagulates.' In the preparation of 'rennet curd' the same end is attained without acid by the use of rennet, an cnzyme prepared from the stomach of calves. In both cases, the casein freed from the serum of the milk (whey) constitutes the 'curds' from which cheese is prepared.

Numerous 'diseases' of milk are caused by bacterial action. Not infrequently it coagulates without turning acid; this is the work of species (Tyrothrix, found in cheese) which secrete an enzyme resembling rennet.

Pigment bacteria often make their appearance spontaneously and cause the milk to have an unnatural colour. Red is produced by $B$. prodigiosus and some Sarcinac, blue by the harmless B. cyanogenus, a small motile rod that grows on agar in dark-blue or bluish-grey crusts according to the food-stuffs available. From ycllow milk also several pigment bacteria have been isolated. These coloured milks have generally become more or less acid. 'Ropy' milk is the work of certain mucigenous bacteria that will be described later on. Bitterness in milk is produced especially by peptone-secreting bacteria that possess very resistant spores.

Butter is always rich in bacteria. A specimen of Munich butter contained from six to twenty-five million per gram. Since the butter contains from 0.5 to $\mathrm{I} .5$ per cent. lactose and other food-stuffs, changes may be set up by the formation of lactic and butyric acids. The butter is thereby rendered rancid, but it must be remarked that the rancidity of butter is in most cases the result of the oxidation of the butter fat to fatty acids (butyric and lactic) by the free oxygen of the air accelerated by exposure to light. The peculiar aroma, too, that renders some butters so tasty, is the product of certain bacteria that are now cultivated in dairy laboratories and added to the fresh butter (90).

A process of great complication, the details of which are difficult to follow, is the ripening of cheese. This is the work of many kinds of bacteria, which are therefore present in cheese in enormous numbers (91). In a gram of German cheese from five to six million germs have been 
found, in the same quantity of Swiss chcese one million, in other sorts still more. In the preparation of Roquefort cheese a mould fungus (Penicillium glancum) is introduced with mouldy bread, and forms the wellknown green patches in the checse. In other cases, forms like Oidium and also yeast fungi play a part.

Not all the bacteria of cheese are equally active in the ripening process; many are only useless intruders, others perhaps contribute to the finer shades of flavour. The main part of the process is the work of the lactic and butyric ferments. Forms that were once supposed to be specific 'cheese bacteria' (Tyrothrix, Duclaux, allicd to B. subtilis) do not play the important part that was attributed to them. How difficult it is to determine the share which the various species have in the process, is shown by the fact that in some checses no. less than nineteen different bacteria and three yeasts have been found. In other kinds the flora is still more varied, and it changes, moreover, with the different stages of the ripening process. This is the reason that, in spite of numerous and careful investigations, the bio-chemistry of cheese has but few results to show, and those contradictory. Even the qualitative composition of checse varies, and a quantitative analysis is as yet no more possible than in the case of putrefactive processes. Emmenthaler cheese contains lactic, butyric, and phenylamidopropionic acids, leucin, tyrosin, ammonia, casein (partly unchanged, partly in the form of soluble albumoses), fats, and fatty acids. The fresh curds from which cheese is prepared contain chiefly three substances, whose gradual alteration constitutes the ripening: I. Carbohydrates (milk sugar); 2. Proteids (casein and paracascin); 3. Fat. The milk sugar is converted first by the lactic bacteria, and afterwards by the butyric bacteria, into organic acids, $\mathrm{CO}_{2}$, and free hydrogen. It is these gases which cause the cavities in the cheese. The casein is changed, by the action of the enzyme sccreted by the bacteria, into an albumose-like body (improperly called caseoglutin), and a small portion of it further split up into tyrosin, lcucin, ammonia, and phenylamidopropionic acid; but genuine putrefactive products, like skatol or indol, are not formed. The ripening of cheese cannot therefore be regarded as a true putrefaction, but only as an allied process in which fatty acids arise. The conversion of the casein goes on very gradually until, by the time the ripening is finished, there is none left in an unchanged state. It is not known preciscly what species of bacteria are instrumental in effecting this alteration. Fat is not formed from casein, and the butter remaining in the curds is for a long time unaffected, but towards the end of the process it is split up into glycerine and fatty acids. Of these phenomena the two of chief importance are the fermentation of the milk sugar and the alteration of the casein.

Another derivative of milk, kephir, is produced by the united action of lactic acid bacteria and a jeast (Saccharmy'cs). Kephir is a weakly 
alcoholic effervescent beverage that has been used for centuries in the Caucasus, where it is usually made from mare's milk. With us cow's milk is generally employed. The 'kephir grains' with which it is prepared contain both the bacterium and the yeast. The yeast cells secrete a peculiar enzyme (lactase) that converts the milk sugar into grape sugar, which is then fermented to alcohol and $\mathrm{CO}_{2}$. The lactic bacteria, besides giving the pleasant acid taste to the drink, cause the precipitation of the casein in a very finely flocculent, easily digestible form. Acetic and succinic acids arise as by-products (91).

In distillcry opcrations (92) the development of butyric bacteria was formerly much dreaded. In the preparation of sweet mash from green malt the heating for two hours at $70^{\circ}$ is naturally insufficient to kill the spores. Experience showed, however, that a certain degree of acidity in the mash prevented the development of butyric bacteria without injuring the yeast cells, and careful investigation showed that the acidity was caused by the lactic ferment. In practice the end is attained by inoculating some of the sweet mash containing the yeast to be used with pure cultures of a lactic bacterium, and keeping it at $50^{\circ} \mathrm{C}$. (the optimum for these organisms) for some time before adding it to the main body of the mash. At $50^{\circ} \mathrm{C}$. the lactic bacteria flourish and produce as much as I per cent. of lactic acid, and the growth of the butyric organisms, whose optimum is $40^{\circ} \mathrm{C}$., is inhibited both by this temperature and by the lactic acid.

This important application of lactic fermentation is now largely superseded by Effront's hydrofluoric acid method. The yeasts are far less sensitive to acids generally than the bacteria, and by continued culture with increasing quantities of acid they may be accustomed to such large amounts that the bacteria are reduced to a minimum, or even quite suppressed. In a few months the alcohol yeasts may be accustomed to as much as thirty milligrams of hydrofluoric acid per hectolitre mash, ten mg. sufficing to kill the bacteria. Other poisons also have been tried; formaldehyde, for instance, which seems more efficacious even than hydrofluoric acid. For electrical sterilization see p. 72 .

The spoiling and 'turning' of beverages and articles of food through lactic fermentation is a common occurrence. Beer must contain more than 7 per cent. alcohol if it is to be safe from the attacks of the lactic bacteria, which, if they once get a foothold, soon cause it to 'turn,' making it turbid and giving it a bad taste. Wine, too, is often spoiled by the same organisms, and may contain as much as 2 per cent. lactic acid, derived from the fructose. The acidity of wine is, however, more often caused by the acetic bacteria than by the lactic. Boiled vegetables are not infrequently soured by both lactic and butyric fermentation.

The various methods of fodder preparation (93), brown hay, sour fodder, and sweet ensilage, are fundamentally lactic fermentations by which the hay 
is made both durable and more tasty for the cattle. Saucrkraut is another foodstuff that is the result of such fermentation. In all these cases butyric fermentation occurs at the same timc.

\section{Butyric Formentation (94).}

The butyric fermentation, a strictly anaerobic process, is no less widely distributed in nature than the lactic. Its importance for the gencral theory of fermentation will be considered in the next chapter.

There are several means of obtaining rough, impure fermentations of butyric bactcria from which, by growing in hydrogen or by other anaerobic methods, purc cultures may be derived. It suffices to place some peas in a saccharine nutritive fluid and close the culture flask with a cork through which passes a tube whose outer end dips under water. In a few days at $30^{\circ}$ or $40^{\circ}$ active fermentation scts in, large quantities of gas are given off, and an odour of butyric acid is apparent. Another method is to boil a mixture of $5 \mathrm{grm}$. grape sugar and $5 \mathrm{grm}$. powdered fibrin in 100 c.c. watcr, and inoculate the liquid, whilst boiling, with a little garden earth. After forty-eight hours at $35^{\circ}$ the fermentative process is going on rapidly, and is causcd almost entirely by onc spccics of bacterium, the Granulobacter saccharobutyricus of Beyerinck.

Just as was the casc with the lactic fermentation, the butyric formentation was supposed formerly to be the work of one specics of micro-organism only, the Vibrion butyrique of Pasteur (Amylobacter butyricus, van Tieghem). There can be no doubt, however, that these terms have both morphologically and physiologically only the value of collective designations, as is the casc with the Clostridium butyricum of Prazmowski. Some twenty different forms of butyric bacteria have been more or less precisely described, and the number could be probably reduced to two or three. Many are distinguished by the granulose reaction (Beyerinck's biological genus Granulobacter), and some are characterized by the alteration in shape of the cell during sporulation, a process which sets in with great regularity towards the end of fermentation (Fig. 24, $c, f$ ). The commonest form of the sporc-bearing cell is the spindle shape (Clostridium), but some species swell at the end (drum-stick, Plectridium). Almost all arc comparatively large cells $\left(0.5^{-1} \mu\right.$ by $\left.3^{-10} \mu\right)$ actively motile and peritrichous (Fig. $\left.24, c, f\right)$.

Granulobacter saccharobutyricus and G. lactobutyricus (anacrobic Clostridia with granulose), and Bacillus orthobutylicus (an anaerobic Clostridium with no granulose), all produce considerable quantities of butyric acid, with some $\mathrm{CO}_{2}$, frec hydrogen, acetic, and traces of other fatty acids. B. orthobutylicus ferments carbohydrates and other compounds of many different kinds ; glycerine, mannitc, glucose, cuvert-sugar, cane-sugar, maltose, lactose, arabinose, starch, dextrine, inuline (not trehalose), crythrite, and gum arabic. 
In some cases, of course, the fermentation must be preceded by inversion by enzymes. The other two species mentioned are, as their names imply, more particular, and need grape, cane, or milk sugar as food.

2.4 grams of glucose fermented by $B$. orthobutylicus yielded in twenty days

$\begin{array}{ll}\text { Grams. } & \\ 0.842 & \text { Normal Butyric acid } \\ 0.264 & \text { Butylic alcohol } \\ 0.229 & \text { Acetic acid }\end{array}$

besides free hydrogen and $\mathrm{CO}_{2}$. These gases increased by continued fermentation, probably showing that the organism can split up its own products into still simpler compounds down to $\mathrm{CO}_{2}$.

A granulose-bearing species from the soil, described by Beyerinck as Granulobacter butyricus, is particularly worth notice, since it forms from maltose, not butyric acid, but butylic alcohol with some $\mathrm{CO}_{2}$ and free $\mathrm{H}$.

Not infrequently butyric acid arises as a product in putrefactive processes, and it seems that some butyric bacteria (B. butyricus, Hueppe) have true saprogenic properties, and can break up proteids. Other species, like B. orthobutylicus, can form butyric acid from peptone only in the presence of one of the above-mentioned non-nitrogenous bodies.

Milk soured by $B$. lactis is often infected by butyric organisms which disintegrate both the remaining milk sugar and the lactic acid that has arisen from it. The fermentation of the calcium salt of lactic acid exhibits this change in an uncomplicated form *.

\section{Ccllulose Fermentation.}

In manure heaps and in the rotting vegetation at the bottom of lakes and ditches there is going on side by side with the disintegration of carbohydrates in plant tissues another process, a special fermentation of cellulose known as methane or marsh gas fermentation (95). The organisms which effect this change first of all 'invert' the cellulose (i. e. break it up into a sugar) by means of an enzyme

$$
\left(\mathrm{C}_{6} \mathrm{H}_{10} \mathrm{O}_{5}\right)_{n}+\left(\mathrm{H}_{2} \mathrm{O}\right)_{n}=\left(\mathrm{C}_{6} \mathrm{H}_{12} \mathrm{O}_{6}\right)_{n}
$$

and then ferment it to methane $\mathrm{CH}_{4}$ and carbon dioxide, fatty acids arising as by-products. Methane, mixed with free hydrogen and $\mathrm{CO}_{2}$, rises to the surface when the mud at the bottom of ponds is stirred up with a stick.

There seem to be a considerable number of methane bacteria. The Vibrio rugula (anaerobic, granulose-bearing) probably is one. Another species (a delicate anaerobic motile Plectridium) that has been isolated from

* For butyric bacteria in cheese-making see p. II9; their distribution in nature, p. 135 ; their assimilation of nitrogen in the soil, p. 96 . 
sewer contents is able to ferment filter paper (pure cellulose). The paper becomes soft and transparent, and is finally completely dissolved. Methane bacteria are at work also in the intestines of herbivores and of man, and cause distention by the gases they produce.

\section{Mucilaginous Fermentation (96).}

IVinc, beer, and milk sometimes become 'ropy,' slimy or 'stringy'; boiled vegetables, too, sometimes undergo the same change. This is due to the growth of bacteria, which ferment the carbohydrate constituents of the liquid, and whose chicf product is mucilage, carbon dioxide, free hydrogen, and the inevitable fatty acids arising as by-products. In some cascs the nascent hydrogen combines with dextrose to form mannitc. The mucilage is a gum-like carbohydrate allied to vegetable gums, and having the same composition as cellulose $\left(\mathrm{C}_{6} \mathrm{H}_{10} \mathrm{O}_{5}\right)_{n}$. It is not a fermentation product, however, in the true sense; that is to say, it is not a direct result of the protoplasmic metabolism, but arises through the imbibition of water by the outer layers of the cell-membrane. It is, in fact, similar to the jelly that holds together the cells in a zoogloea. A useful task would be the investigation of the nature of the unaltered inncr layers of the cell-wall, which consist perhaps of a cellulose-like carbohydrate.

A number of mucilaginous bacteria have been described, and the specics are said to be different for different kinds of sugars. B. viscosus sacchar $i$ is said to flourish only in fluids containing cane sugar, a nother only in grape sugar (winc), and a third (B. viscosus lactici) in milk sugar.

\section{Fermentations in technical processes.}

Wherever fermentable material is handled on a large scalc thcre is danger of the invasion of ferment bacteria. And in many processes that 'go on of themselves' we must assume that bacteria are at work. Places where such changes occur, and where the bacteriologist must seck for them, will occur to every onc. Some cases, such as the souring of bark liquor in tannery, have already been tentativcly cxamincd. It will be worth while to mention a few others.

The 'Retting' of Vegetable Fibres (97), such as flax and hemp, is also the work of bacteria. The tissues are allowed to soak for a long time in water, and fermentation sets in, the fibres being freed from the enclosing cells by the solution of the middle layer of the cell-walls. This inter-cellular cementsubstance consists of so-called pectine compounds (pectine salts of calcium) related to carbohydrates, which are dissolved by the bacteria. The fibres can then be scparated by mechanical means. Up to the present we know only one of the micro-organisms concerned, an anacrobic Plectridium $(10 \mu-15 \mu$ by $0.8 \mu)$, which can use ammonia as a source of nitrogen and 
ferments pectine substances prepared from linseed, pears, or turnips. Cellulose and gum arabic are not attacked, but the power of breaking up other carbohydrates is greatly increased if peptone be supplied instead of ammonia. As to the products of pectine fermentation nothing is known, but they are probably, as in other cases, $\mathrm{CO}_{2}$ and fatty acids. The old idea that the process was one of cellulose fermentation is certainly wrong.

In the manufacture of indigo bacteria are considered to play an important part (98). The indigo plant (Indigofera tinctoria) contains a glucoside Indican which by anaerobic fermentation at $25^{\circ}-35^{\circ} \mathrm{C}$. is converted in from eight to fifteen hours into a sugar (Indigoglucin) and indigo-white. The fermentation is carried on in large vats, the liquid in which becomes blue on the surface where it is exposed to the air. By agitation the whole mass is brought into contact with air, and becomes blue throughout. The microorganism which ferments the indican is a short capsulated bacillus, $B$. indigoscmus. If the fluid be sterilized and the bacteria killed, no pigment is formed. The process has not yet been followed in detail.

The preparation of tobacco involves, to a considerable extent, the work of bacteria (99). The dried leaves of the plant are damped and laid in great heaps to 'ferment.' By this process various carbohydrates, nicotine, and vegetable acids are converted into $\mathrm{CO}_{2}$, butyric acid, succinic acid, and certain 'aromatic bodies,' whose nature is not precisely linown. The proteids are said not to be attacked. Various species of bacteria have been isolated from the tobacco leaves. The 'Havannah' bacteria are said to differ from those of the German weed, and the inoculation of the latter with Havannah bacteria has been to some extent successful. The process is comparable to the improvement of wines by the inoculation of the grape juice with specific pure yeasts. It is, however, doubtful whether the real aroma of Havannah tobacco can be transferred in this way, since the aromatic compounds of the plant itself have to be considered, not merely those produced zymogenically.

In the beet juice of sugar factorics, and also in refineries (100), the 'frog-spawn bacterium ' (Leuconostoc mesenteroides) is sometimes a great pest (Fig. $7, b-d$ ). It is a mucigenous bacterium, and the chemical changes it sets up have been designated as dextrane fermentation, because the mucilage that appears in such profusion is supposed to be similar to a carbohydrate of the beetroot, dextrane. The matter requires further investigation, however. At the optimum temperature $\left(30^{\circ}-35^{\circ}\right)$ the micro-organism grows with extraordinary rapidity, and whole vats may be filled with it in the course of a single night*. Besides mucilage, the bacteria produce lactic acid and $\mathrm{CO}_{2}$. The molecules of the fermentable substances are not so completely

* In one case a vat of 49 hectolitres molasses, containing 10 per cent. sugar, was filled in twentyfour hours with the spawn-like masses. 
disintegrated as in many fermentations. The bacterium is a coccus with fixed planes of division, and, like the alga Nostoc, forms unbranched rosarylike chains embedded in jelly. Cane and grape sugar are necessary for the production of the mucilage. In media containing neither of these carbohydrates, the organism grows as a simple Streptococcus, without any capsule.

In bread-making (101), too, we cannot dispense with the help of microorganisms, which are important agents in the conversion of the nutritious wheat meal into a tasty bread. Yeast, as used by bakers, consists of a mixture of Saccharomyces cells (the alcohol ferment), and of different species of bacteria. The bacteria, to some extent, prepare the starch for the yeast by enzymes, and contribute to the taste of the bread by the organic acids (lactic and acetic) they produce. The fermentation set up by the yeast gives rise, per kilogram of bread, to about $2.5 \mathrm{grm}$. alcohol and $2.7 \mathrm{grm} . \mathrm{CO}_{2}$. This gas it is which causes the bread to 'rise,' and the inflation is of course increased by the expulsion of alcohol vapour and steam, which takes place in baking. Some of the fermentation products finally remain in the bread and affect its taste. 


\section{CHAPTER XIV}

\section{THE CIRCULATION OF CARBON DIOXIDE IN NATURE (continued)}

\section{The Yeast Fungi and Alcoholic Fermentation. Theory of Fermentation and Anaerobiosis. Concluding Remarks on the Circulation of Nitrogen and Carbon in Nature.}

THE most important of all fermentative processes, from an industrial point of view, the alcoholic or vinous fermentation, is the work not of bacteria, but of yeast fungi. Some few bacteria are, as we have seen, able to produce ethyl alcohol, e.g. B. cthaccticus, but in all the great technical fermentations, in the manufacture of beer, wine, and spirits, the ferment organisms are yeasts (Saccharomycetes, Blastomycetcs) $(102,103)$. The yeasts are unicellular non-motile organisms, not cylindrical or spherical in shape like the bacteria, but spheroidal (Fig. 25). The shape of the cells, to some extent of value as a classificatory character, appears at first sight more irregular than it really is. This is due to the remarkable manner of propagation. The yeast cells multiply not by fission into two equal halves, as do bacteria and the cells of higher plants, but by 'budding.' The cell-wall becomes evaginated at one or more points, and the bud-like projections thus formed are shut off from the mother-cell by a new cell-wall. As the young cells do not at once break away, and even begin to bud themselves before connexion with the parent cells is severed, irregular colonial growths arise. The contrast between this mode of reproduction and the multiplication by fission of the bacteria is very great. Among the bacteria each new generation represents half of the parent generation, which in the very act of multiplication ceases to exist as an individual. In the yeasts a small part only is separated from the parent, which continues to live and bud off further descendants. The process of budding, like that of fission, is very rapid; a new generation may arise in a couple of hours, so that reproduction is little less prolific in the yeasts than in the bacteria.

As with bacteria, the successive generations of yeast_cells often remain 
in close connexion. But, inasmuch as the budding is irregular, new individuals sprouting out from any part of the surface of the cell, the colonies or growth forms that arise are also irregular, branching out not only in one plane, but in all directions, without any definite sequence of growth (Fig. 25). The cells are often elongated, sausage-shaped, and the tangled colonies or 'growth forms' have then almost the appearance of

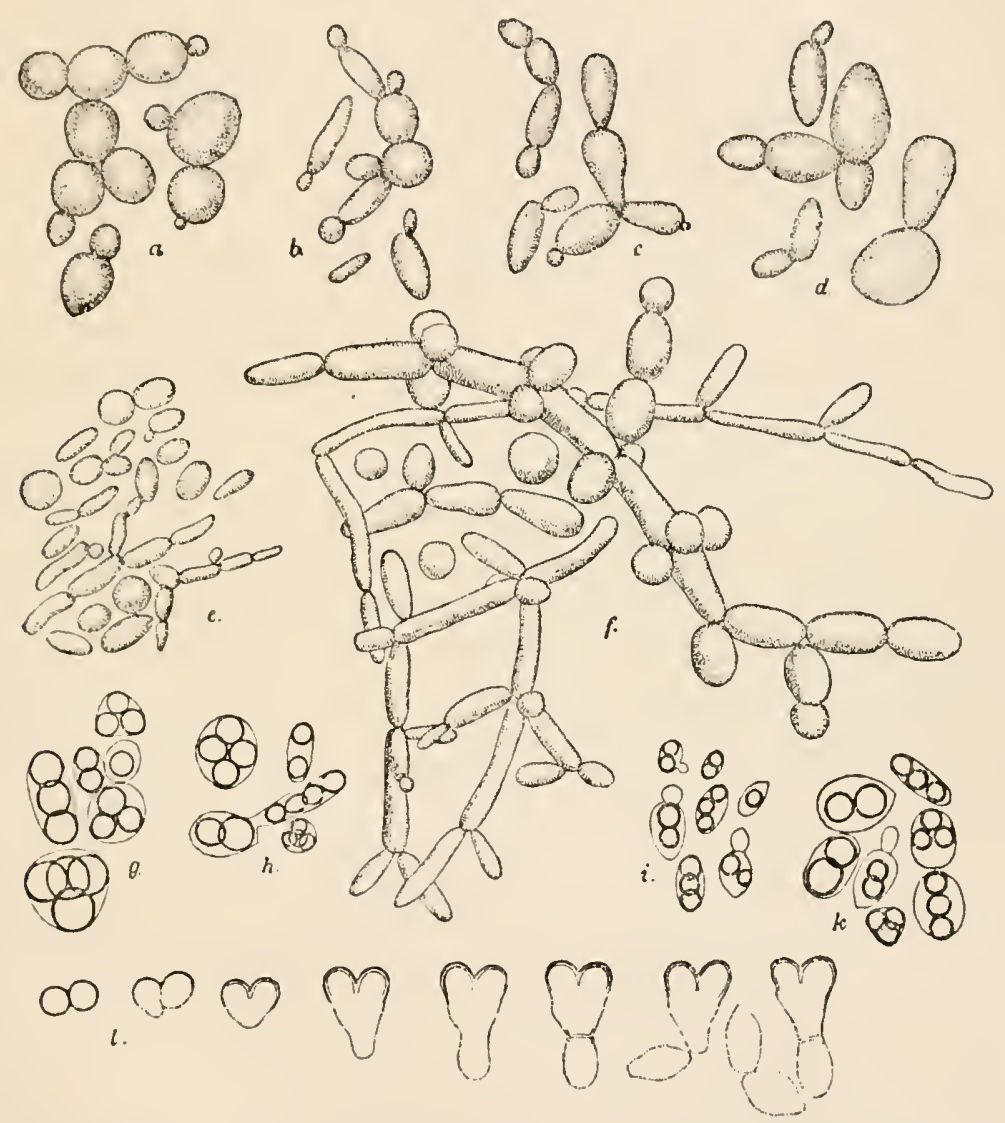

FIG. 25. Saccharomyces. a, Saccharomyces cerevisiae, No. 1. b. Sacch. Pasteurianus, No. 3. c, Sacch. ellips. oiteus (wine-yeast), No. I. $d$, Sacch. ellipsoideus, No. 2. $e$ and $f$ pellicle growth (pseudomycelium) of Sacch. ellips., No. $1 ; e$, at $30-20$ or $6-7 ; f$, at $15-30$ '. $g$ - $k$, spore-bearing cells; $g$, Sacch. cerezisiae, $1 ; h$, Sacch. Pasteur. $1 ; i$ and $k$, Sacch ellips., i and 2. \%, germination of two free spores of Sacch. Ltedwigit at is $-20^{\circ}$, from left to right, after $18,20,26,28,29,30 \%$, and 33 hours respectively. All cultures in beer-wort, wagn. 1000 (from E. Chr. Hansen).

mycelia (Fig. 25. $\mathcal{e}$ and $g$ ). Such pseudo-mycelial masses arise both immersed in liquids and on the surface. In the latter position they often unite to form membrancs or pellicles ('veils'), as we saw was the case with some bacteria. Their mode of origin show's them to be, however, not true mycclia, but only 'growth-forms.'

The yeast cells, like those of other plants, consist of a membrane 
enclosing the protoplasmic cell body, which apparently contains a nucleus*. Although very minute, the yeast cells are larger than most bacteria, having on an average a diameter of from $8 \mu$ to $10 \mu$. All the yeasts that are of industrial importance are colourless, and their cultures appear white or of a yellowish tinge. There is, however, a pink yeast (Saccharomyces glutinis, weakly fermentative) that frequently crops up as an intruder on culture plates, and a less common black species is known.

Most yeasts under favourable circumstances (free access of air; surface culture, not immersed; temperature about $25^{\circ} \mathrm{C}$.) form spores. Instead of each cell giving rise to one endospore, as in bacteria, several appear, the protoplasm of the parent-cell dividing into several (generally two to four) rounded masses, each of which becomes surrounded by a new membrane (Fig. 25, $g, k$ ). The spores are considerably less resistant than those of bacteria, being killed by a temperature of $62^{\circ}-70^{\circ} \mathrm{C}$. in five minutes. They are capable of germination as soon as they are formed, but will withstand drying for long periods. The germinating spore begins to bud as soon as the spore-wall is thrown off (Fig. 2.5, l).

Hansen's investigations have shown that in the hands of skilled observers who are familiar with the sources of error, the peculiarities of sporulation and its relation to certain temperatures, are of great importance for the differentiation and determination of species and races.

The following table gives the times of sporulation for a 'high' yeast (S. cerevisiae), for a race of wine yeasts (S. ellipsoidens), and for two races of 'wild' yeasts from the air of a brewery (S. Pasteuriamus). Important points are the optimum and the maximum temperatures, and the time occupied in forming the spores.

\begin{tabular}{|c|c|c|c|c|}
\hline \multirow{2}{*}{ Temperalure. } & \multirow{2}{*}{ S. cerevisiae. } & \multicolumn{2}{|c|}{ S. Pasteurianus. } & \multirow{2}{*}{ S. ellipsoideus. } \\
\hline & & a. & $b$. & \\
\hline $\begin{array}{c}37 \cdot 5^{\circ} \\
36^{\circ}-37^{\circ} \\
35^{\circ} \\
31 \cdot 5^{\circ} \\
30^{\circ} \\
27 \cdot 5^{\circ} \\
25^{\circ} \\
18^{\circ} \\
11^{\circ}-12^{\circ} \\
7^{\circ} \\
3^{\circ}-4^{\circ}\end{array}$ & $\begin{array}{l}\text { no spores } \\
29 \text { hours (Max.) } \\
25 \text { hours } \\
20 \text { hours (Opt.) } \\
23 \text { hours } \\
50 \text { hours } \\
10 \text { days (Min.) } \\
\text { no spores } \\
\text { no spores }\end{array}$ & $\begin{array}{l}\text { no spores } \\
30 \text { hours (Max.) } \\
24 \text { hours (Opt.) } \\
35 \text { hours } \\
7 \text { days } \\
14 \text { days (Min.) }\end{array}$ & $\begin{array}{l}34 \text { hours (Max.) } \\
25 \text { hours (Opt.) } \\
36 \text { hours } \\
77 \text { hours } \\
7 \text { days } \\
\text { I } 7 \text { days (Min.) }\end{array}$ & $\begin{array}{l}2 \text { I hours (Opt.) } \\
33 \text { hours } \\
\text { I I days (Min.) } \\
\text { no spores }\end{array}$ \\
\hline
\end{tabular}

* See Wager, 'The Nucleus of the Yeast-Plant,' Amnals of Botany, Vol. XII, Dec. I898, p. 499. 
The cardinal temperatures for sporulation are given and show the value of such physiological data. For the differentiation of very closely related races more subtle distinctions are utilized, such as the shape of the cells, mode of budding, power of fermentation, and particularly the ability to break up various sugars of closely allied chemical structure.

Some of the natural species of yeasts are destitute of spores. Hansen (104), guided by the attempt to cultivate a sporelcss breed of anthrax bacilli, endeavoured to induce the asporogenous condition among spore-bearing yeasts by similar means, i. e. by cultivation at high temperaturc. His experiments were successful; sporulation was suppressed and did not appear in subsequent generations. At the same time the fermenting powers of the yeast were slightly altered. It seemed at first that the attempt to obtain sporclcss races had been more successful among the yeasts than with the bacteria, but subscquent obscrvations showed that the phenomena were the same in both cases. When mixed with earth, the sporeless varieties of yeast died out in one year, whercas the unaltered spore-bearing form of the same species lived for three years under the same conditions. This fact alone shows that a general weakening of the organism had set in, and other signs of degeneration were not wanting. But although the attempt to produce races of yeast with new morphological characters has not been an unimpeachable success it is undoubtedly possible to obtain races with more or less permanently altered physiological functions-races that produce more (or less) alcohol than the parent form, or in which the by-products of fermentation are different or present in different proportions. In the brewing industries (105) hundreds of such races have alrcady arisen, and give to each particular kind of beer its specific flavour, while Hansen's investigations have led to the application to yeasts of the methods of pure culture, so that the most desirable varieties can be artificially propagated.

The winc ycasts also include innumerable races. Almost every kind of wine has its own species of Saccharomyces. The secondary products of fermentation are of great importance, particularly the aromatic substances (cthers) which give the 'bouquet.' But, whilst these zymogenic products are undoubtedly influential in determining the flavour of the wine, it must not be forgotten that the aromatic constitucnts of the grape itself are of still more importance. The purc culture of yeasts of known fermentative properties is a great step forwards, but it is not everything. It will never be possible, for instance, to make a sour inferior Rhine wine into an expensive Johannisberger merely by the use of the Johannisberg yeast (105).

In the old methods of winc-making the fermentation was left to 'go on of itself'; in other words, it was left to the ycasts accidentally present in the grape juice. The grapes hanging on the vines always have 
on their skins numerous yeast cells, which multiply rapidly on burst or broken grapes and are carried about by insects from one plant to another. After the grapes have been gathered, millions of yeast cells remain in the soil, where they pass the winter until next year's crop supplies them with fresh food.

When the fermentation is to be made with a pure yeast, it is not necessary to kill the Saccharomyces already present in the grape juice by heat; it is sufficient to add a large quantity of the pure culture, the organisms in which usually easily overcome the less numerous 'wild' yeasts.

The term 'species' has the same meaning and value among the Saccharomyces as among the bacteria, but it must not be forgotten that the yeast fungi are among the oldest of cultivated plants, and that in the course of ages innumerable varieties and races have arisen. The various yeasts of breweries and distilleries must all be looked upon as varieties of the one species S. cerevisiae, and a few others, those used in winemaking, as races of $S$. ellipsoideus (Fig. $25, a, c, d$ ), a somewhat smaller, thinner form than $S$. cerevisiae.

The peculiar mode of propagation of the Saccharomycetes characterizes them as a definite and independent group of organisms, whose systematic value is the same as that of any other order of fungi. This independence would never have been challenged had not a similar budding-off of cells been observed in some other fungi (106). Spores of the smut-fungus (Ustilago) if sown in a decoction of horse-dung germinate and protrude a small few-celled pro-mycelium, which then buds off laterally rounded cells just in the same way as yeasts do. The free-lying rounded cells multiply still further by budding, and give rise to cell groups and colonies indistinguishable, as far as appearance goes, from true yeasts. They are, however, quite unable to set up alcoholic fermentation.

Again, the filamentous hyphae of some of the mucorine fungi, if grown submerged in saccharine solutions, produce cells which sprout and multiply like yeasts, and even cause a small quantity of alcohol to be formed (Mucor racemosus, $M$. erectus, $M$. circinelloides). Finally, there are ascomycetes (Exoascus) which give rise to budding cells, and whose mode of sporulation (ascospores) is suggestive of the sporulation of yeasts. On these various and insufficient grounds the independence of the Saccharomycetes as a group has been questioned, and the suggestion has been made that they are nothing but derivatives of higher groups that have lost the power of repeating the cycle of forms which their ancestors went through. But none of the Saccharomycetes ever show any indications of a higher type of growth; they produce vegetative cells, cell groups and spores, and never anything else. The announcements that have been made from time to time, that true yeasts have been cultivated from higher 
fungi, have all proved to be erroneous (106). As to the mode of propagation by budding, there is no reason why it should not have appeared independently in several groups, and there are therefore no adequate grounds for refusing the Saccharomycetes the position of a separate selfcontained phylum.

The Saccharomycetes are metatrophic and need the same food-stuffs as many bacteria. As a source of nitrogen, peptone is by far the best, and after it asparagine; but ammonia salts suffice if nothing better is to be had. Carbon is obtained from the fermentable material, sugar, which may be present in quantities up to 35 per cent. (optimum, 2-4 per cent., or 20-25 per cent.). Where the object is not fermentation of the substratum, but culture of the organisms, the sugar may be replaced by other substances, such as glycerine or mannite. In direct contrast to most bacteria, the yeasts are not affected by an acid reaction of the culture medium, but are arrested in their growth if frec alkali be present. This peculiarity is of great advantage in brewing and distillery, for by maintaining the acidity of the liquid (wort) in the vats the development of many injurious bacteria is prevented, whilst the yeast cells are unhindered in their fermentative power (see p. I20).

Of the carbohydrates only the monosaccharides with the formula $\mathrm{C}_{6} \mathrm{H}_{1:-} \mathrm{O}_{6}$ (c.g. glucose, fructose, galactose) are directly fermentable (107). The disaccharides $\left(\mathrm{C}_{12} \mathrm{H}_{22} \mathrm{O}_{11}\right)$, cane sugar, maltose and lactose must be inverted before they can be fermented; that is to say, they must be changed into monosaccharides (107)*. This is effected, as we have already seen, by the hydrolytic action of enzymes excreted by the yeast cells themselves. By an enzyme called invertase the beer and wine yeasts change cane sugar into the so-called invert sugar, and by another, known as maltase, they change maltose into glucose. Neither of these yeasts can hydrolyze milksugar, and therefore cannot ferment it. This is effected, however, by the Saccharomycetes found in Kephir grains (p. 120) which secrete an enzyme (lactase) that inverts the lactose in milk. Every species of yeast has its own peculiar zymolytic properties.

The polysaccharides other than sugars (cellulose, starch, dextrine, gums, \&c.) are not attacked by the yeasts until they have been converted into sugars by enzymes of other origin. In the preparation of beer, for instance, the starch of the barley grains is converted into maltose by an enzyme (diastase) contained in the grains themselves.

Every fermentation gives rise, apart from the chief products, to numerous other substances. The following table shows the quantities of these by-products formed in the fermentation of $\mathrm{r}, \infty \infty \mathrm{gr}$. of grape-sugar.

* Probably the various new synthetically-produced sugars will also be arrangeable in accordance with their structure and ability to be fermented. 
(N. B.-The yeast employed was a wine-yeast, but not a 'pure-culture' according to modern ideas) (108):

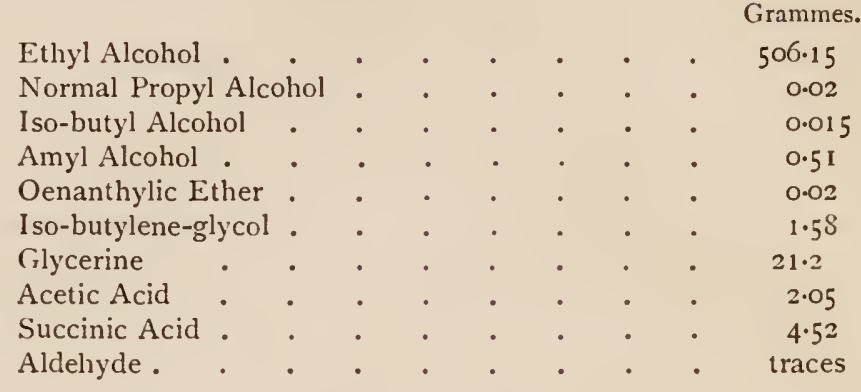

In other words, $506 \mathrm{grm}$. alcohol and about $30 \mathrm{grm}$. of by-products, to which is to be added about $45^{\circ} \mathrm{grm} . \mathrm{CO}_{2}$ (estimated). Some one per cent. of the sugar was used by the yeast as food. It is noticeable that as much as two per cent. glycerine is present. This is of some importance, for it has more influence than might be supposed upon the taste of the wine. The two next most important products are acetic and succinic acids.

The example just given is of course only one of many different kinds of fermentation; it must not be taken as a standard. The by-products particularly are very different both as regards quantity and composition in the different technical fermentations. In distillation higher alcohols (e.g. fusel oil) than ethyl alcohol are found. In wine the compound ethers (esters, compounds of alcohols and organic acids) are of prime importance because, although present in homoeopathic quantities, they are the substances which constitute the 'bouquet.'

As soon as all the sugar in a fermenting fluid is used up the process ceases, as it does also in any case when the alcohol has reached $\mathrm{I} 2$ or $\mathrm{I} 4$ per cent. It is from this cause that many Spanish wines remain sweet, alcohol being added to them in order to increase their permanence (?).

Alcoholic fermentation (opt. $25-30^{\circ}$; min. about $0^{\circ} ; \max$. about $53^{\circ}$ ) can progress both aerobically and anaerobically. When air has free access to the fermenting fluid the yeast cells multiply with great rapidity, but the power of fermentation, that is to say, the amount of sugar broken up by unit weight of yeast in unit time, is very small. Conversely, if oxygen be absent or only very sparingly present, the fermentative power of the organisms is great, but the rate of growth very slow. This is best illustrated by a concrete example. To entirely ferment (i.e. to consume all the sugar in) 300 c.c. 'must,' twenty-three days were necessary. The time was the same whether air was present or absent, but the number of cells in each case was very different. Where complete aeration was carried out the fluid contained at the end of fermentation $4,454,800$ cells per cubic centimetre, whilst if air was excluded only 50,160 per c.c. were found (109). It is evident that the 
cells in the last case must have been proportionately more powerful in effecting fermentation.

All the technical fermentations are, as a matter of fact, anacrobic processes, for although at first air is contained in the liquids in the vats, and has unhindered access to them, the commencement of the fermentative process alters conditions immediately. The oxygen in the liquid is used up at once by the organisms, and the $\mathrm{CO}_{2}$ they evolve lies in a heavy stratum over the contents of the vats, completely shutting off the access of atmospheric oxygen. Under these circumstances the cells are able to develop their full fermentative power and produce most alcohol. If the object to be attained is not the fermentation of sugar but the growth of the yeast plant, as in establishments for the preparation of 'pressed' yeast, plentiful aeration must be provided for.

\section{Theory of Fermentation and Putrefaction (110).}

The fact that many fermentative processes take place in the absence of oxygen would seem at first sight to give us some clue to the nature of the phenomena. Comparisons have been drawn between fermentation and the so-called 'intramolecular respiration' of higher organisms. Intramolecular respiration is a term applied by physiologists to the faculty possessed by plants and animals of existing for a short time in an atmosphere devoid of oxygen (pure hydrogen, for example), at the same time giving off $\mathrm{CO}_{2}$ and forming in their tissues a minute quantity of alcohol. It seemed as though all living substance were able to exist for a short time without oxygen, splitting up respirable material (carbohydrates and perhaps albumens) just as the Saccharomycetes do. The power of fermenting sugar would indeed be only a special case of intramolecular respiration.

We must not however forget that, even apart from purely oxidatory changes such as the acetic fermentation, by no means all fermentative processes are anaerobic. The work of the methane bacteria and of most butyric organisms is indeed strictly anaerobic, but alcoholic fermentation, although most vigorous in the absence of oxygen, is not arrested by the presence of this gas, and most other fermentative processes are similar in nature, i. e. they are facultative anaerobic.

The term 'intramolecular respiration' is intended to indicate a process in which, although $\mathrm{CO}_{2}$ is excreted, the oxygen is taken not from the atmosphere, but from the complex molecules of the respirable substance (e.g. sugar), which is broken up into the various less complex bodies we call 'products of fermentation.' That such reductions do in fact take place in anaerobic fermentation (e.g. butyric) may be proved by adding to the fermenting fluid organic colouring-matters such as indigo or methylene blue which become decolourized, that is to say they are converted into the 'leuco' compound with two additional atoms of hydrogen in the moleculc. 
The bleached solutions become blue again if shaken up with air, showing that there has been no far-reaching decomposition of the molecule. All that has happened is that nascent hydrogen has been taken up from the molecules of the fermenting substance. Whether the hydrogen is set free in consequence of the organism seizing oxygen from those molecules, or whether part of it is due to some other disintegration going on in the living protoplasm, is unknown to us. In any case, it is plain that Pasteur's dictum, 'Fermentation is life without oxygen,' does not quite correspond with facts. And the circumstance that fermentation (even alcoholic) can go on in the presence of oxygen is a further argument against such a view, and against the theory that fermentation is a form of intramolecular respiration.

Another explanation, older even than Pasteur's, was that proposed by Traube in 1858 , the 'enzyme' theory. Traube imagined that ferment organisms accomplished all their work by means of enzymes excreted by their protoplasm. Such a view could of course be held only as long as it was thought that fermentation was a simple splitting-up of complex molecules into smaller ones: for instance, that alcoholic fermentation took place according to the formula

$$
\mathrm{C}_{6} \mathrm{H}_{12} \mathrm{O}_{6}=2 \mathrm{C}_{2} \mathrm{H}_{6} \mathrm{O}+2 \mathrm{CO}_{2} \text {, }
$$

and that no by-products arose. Since we now know that a large number of by-products are formed, and since it has not been possible to isolate the supposed enzymes, Traube's theory had to be abandoned (111). In one case only, that of the ammoniacal fermentation of urea, did it seem likely that the change was effected by an enzyme, for the process is one of simple hydrolysis

$$
\left(\mathrm{NH}_{2}\right)_{2} \mathrm{CO}+2 \mathrm{H}_{2} \mathrm{O}=\left(\mathrm{NH}_{4}\right)_{2} \mathrm{CO}_{3} \text {. }
$$

The enzyme in question, 'urase' (112), has now been isolated. It is a body of great instability.

The difference between the work of enzymes and organized ferments must be here again referred to. Enzymes are doubtless active in all fermentative processes, but the changes they bring about are only preparatory; for example, the inversion of sugars by yeasts, and the peptonizing of albumens by putrefactive bacteria. The actual fermentative processes with their numerous by-products are not to be explained by enzymic action, they are effected by the living protoplasm of the cells*.

Another explanation of the phenomena of fermentation, an explanation of a totally different character, was proposed by Nägeli in I 879. According to this, the process is entirely extra-cellular, being brought about by vibrations set up by the molecules of the protoplasm and transmitted to the molecules of the substances outside the cell, which are thereby split up into the various bodies we call products of fermentation. This at first sight very plausible hypothesis is rendered extremely improbable by the fact that the cell is 
surrounded by a rigid membrane which would at least very much weaken the vibrations if it did not quench them. It is true that the explanation is difficult to disprove, but that is always the case with views based on purely hypothetical molecular movements.

The view which perhaps more than any other agrees with the physiological or 'biochemical' nature of the phenomena is that which looks upon them as being the result of chemical processes going on in the living substance of the cells. The fermentative and putrefactive organisms would seem to have properties not possessed by other organisms, properties which enable them to live in places and under circumstances where a complete combustion of the food-stuffs to $\mathrm{CO}_{2}$ and $\mathrm{H}_{2} \mathrm{O}$ is not possible*. The energy that all other plants and animals gain by respiration is obtained by these organisms from a less complete disintegration of the molecules of the respirable substance, the relative smallness of the amount of energy set free being compensated by the large quantity of substance decomposed. In other words, the ordinary respiration of plants and animals is a complete combustion of a few molecules, that of the ferment organisms an incomplete combustion of many molecules. The products of fermentation therefore are, unlike the products of respiration, bodies whose heat of combustion is still high; alcohol, for instance, with 3,246 calories, butyric acid with 3,679 calories.

The degree of adaptation (if the expression be allowed) to anaerobic habitats is very different in different organisms. The butyric ferments and the methane bacteria, for instance, are absolutely (obligatory) anaerobic, and have lost the power of ordinary respiration. The alcohol yeasts, lactic bacteria, and most other ferment organisms are only facultatively anaerobic. They are not yet fully weaned from oxygen, which, while not indispensable, is far from being a poison to them. They can, even in the presence of oxygen, exercise their remarkable faculty of partly disintegrating the complex molecules of organic compounds, and gaining a small amount of energy thereby. At the same time these facultative anaerobes can actually respire, that is to say, can burn up completely some of the food-stuffs given them. This is proved by the fact that when alcoholic fermentation goes on in the presence of air a larger amount of $\mathrm{CO}_{2}$ is evolved than corresponds to the alcohol formed. Perhaps it is for this reason that the yeasts grow so quickly when air is available; the extra energy derived from the combustion of the sugar to carbon dioxide and water being used to build up new cell-substance. If oxygen is absent, respiration is not possible; the other source of energy alone is available, and growth and multiplication are necessarily slower.

* E. g. the mud of ponds and ditches, the interior of decomposing carcases, the contents of the intestine, and below the surface of dung-hills-all places in short where fermentation and putrefaction are anaerobic. 
This brief description of the phenomena of fermentation will serve to indicate the scope and nature of the problems involved.

There remain to be said a few words regarding the by-products of fermentation, carbon dioxide, free hydrogen, and (in putrefactive processes) ammonia and free nitrogen. Careful investigation shows that there is a whole scalc of products ranging from compounds whose heat of combustion is high, such as alcohol, down to the gases just mentioned, in which it is very low or nil. There seems every reason to believe that the combustion of both the chief and the by-products is gradual, by stages. In this way there must be going on a number of different processes simultancously in the cell, the various compounds being decomposed, and their energy tapped step by step, a process which must necessarily result in the formation of a large number of bodies of different composition-' by-products.'

The description given in the last five chapters of the circulation of the elements carbon and nitrogen, and of the rôle played therein by bacteria, would be imperfect and inaccurate if no mention were made of the part taken in the process by other micro-organisms. The great importance of bacteria in medicine and in many technical operations has caused them to receive more attention than other groups, and as a result we too often regard them as being the only agents in the disintegration of dead organic matter. This idea is incorrect, for although precise investigations are wanting there can be no doubt that many other protozoa found in abundance where putrefaction is going on, ciliate and flagellate infusoria and amoebac, also take part in the work of destruction. They are not always merely saprophile; they are saprogenic, and assist in the breaking-up of the molecules of organic substance.

Nor should we forget that the mould-fungi and all other plants devoid of chlorophyll are entirely dependent for food on decaying organic matter, the carbon of which they help to dissipate by their respiratory processes. They furthermore convert stable and resistant bodies (such as wood) into the easily decayable substance of their own cells. Not a dead twig or trunk in the forest that does not bear minute Pyrenomycetes silently and imperceptibly eating up the wood, to be in their turn disintegrated and dissipated by the putrefactive bacteria to which sooner or later all fungi fall a prey.

Thus the final destiny of all living substance is sooner or later, directly or indirectly, to become food for bacteria, and it would seem as though the earth must at last be suffocated by their numbers. But, apart from the fact that large quantities of bacteria are consumed by other protozoa (infusoria and amoebae are often crammed full of them), it must be remembered that each bacterial cell lives only for a short time and leaves but a limited if large number of descendants, which in their turn die off and are consumed by their kindred, only to enter again into new cycles of chemical change. 


\section{CHAPTER XV}

\section{BACTERIA IN RELATION TO DISEASE}

\section{Diseases of Plants; Harmless 'Messmates' in the Human Body; Pathogenic Bacteria; Points of Attack and Sources of Infection.}

WiTH the exception of the root-nodules of Leguminosae, we know of no single instance where bacteria invade the closed, living cells of plants. The sole and only channels of communication between the interior of the plant and the outside world are the stomata, and these open into a closed system of air-filled intercellular spaces which are shut off from the cells themselves. If bacterial spores are blown by the wind, or washed by the rain into the stomata, they can do no damage, for they can get nowhere but into the intercellular spaces where they find nothing but moist air. Without nutriment, bacterial spores cannot germinate, and nutriment is not present in any form. Even if such microbes as can dissolve cellulose (methane bacteria) drift into the air passages of a plant, they find no food, and are therefore unable to injure the cell-walls. The only organisms whose entrance is accompanied by any danger are those whose spores contain sufficient reserve nutriment to enable them to germinate in pure water, to grow at first without food, and open the attack on the cell-wall at their own expense. Such are spores of the parasitic fungi. They contain reserve food-stuffs, and protrude a hyphal filament which pierces the epidermis (potato disease), or pushes its way through one of the stomata into the intercellular spaces (rusts), and from thence into the cells themselves. The hyphae of the fungus dissolve the cell-membrane and send in haustoria, or proliferate in mycelial masses in the cell-cavity.

Bacteria are totally unable to act in this way, and the uninjured plant is impregnable to their attacks. Even the injured plant offers them nourishment only in the exposed and opened cells of the wound-surface, and this source is soon shut off by the development of an impenetrable layer of cork below the wound preventing any further exudation of fluids. Thus the 
wound does not remain moist; the injured cells shrink and dry up, and the entrance of bacteria is then as difficult as in the case of an uninjured plant. Infected wounds are therefore dangers that have no existence for plants, and the spread of a lesion to other parts is not possible.

These considerations enable us to prophesy with considerable certainty what will be the result of an injection into vegetable tissues of bacteria, even of a species pathogenic for animals: no development in the intercellular spaces, and but slight temporary growth on moist wounded surfaces, are what we should expect, and what experiments show to actually occur (113).

Notwithstanding these well-known facts, there appear time after time descriptions (generally insufficient enough) of new 'bacterial' diseases in plants. Bacteria, it is true, are often found in diseased plants in enormous numbers, but they are living metatrophically only, living on tissues that have already been disintegrated and decayed by parasitic fungi. The bacteria assist these subsequently in their work of destruction no doubt, and modify perhaps more or less the character of the disease. But, leaving aside for the present injuries received from frost or insects, the first attack on the plant is always made by fungi, which are also very harmful in causing the spread of accidental wounds. All the cases of so-called 'bacteriosis' in plants, from the 'gommosc bacillairc' of the vine down to the 'schorf' of the potato, are primarily diseases of non-bacterial origin in which the bacteria are present merely as accidental invaders (114).

As metatrophic organisms, bacteria occur plentifully upon the leaves of insectivorous plants such as Pinguicula, Drosera, and Ncpcnthes. The insectcatching organs are necessarily open to the surrounding world, and bacteria are blown on to them by wind, and brought by insects and other animals. The half-digested remnants of captured organisms furnish a supply of rich nutriment to the bacteria, and it would be extraordinary indeed if they did not flourish and multiply in such places. Here again attempts have been made to demonstrate a 'symbiotic' relationship between the plant and the bacteria, whose peptonizing powers were supposed to be of service in dissolving the captured insects. Careful investigation has shown these suppositions to be incorrect. In the case of Lathraca, whose leaf-chambers contain hairs often thickly covered with bacteria, it is not certain whether these are metatrophic or not (115).

Among the lower animals bacterial diseases have been as yet but little investigated, although they are doubtless very common. The silkworm discases discovered by Pasteur, and the so-called 'Foul-brood' of bees, are well-known examples. Recently a Bactcrium ranicidum has been described, pathogenic for frogs and fishes (116).

The chief interest as regards disease-producing bacteria is, of course, concentrated on those associated with man and the higher mammalia. The symptomatic characters of bacterial diseases being similar in man 
and other mammalia; the following description will deal only with the phenomena of disease in the human subject.

Many bacterial diseases are common to man and the higher animals, and, as far as we know, there is no parasite of man that is without effect for some animal or another. This fact represents an inestimable advantage in the study of disease, since it enables us, by inoculating animals with pure cultures of bacteria, to put pathological science upon an experimental basis. The whole of our knowledge of micro-organisms in relation to disease, including the promising science of sero-therapeutics, is the direct result of experiments on animals.

Bacteria in the Human Body.-Every human being, even the healthiest, carries about with him innumerable harmless messmates and guests in the shape of metatrophic bacteria. All the cavities of the body that are in communication with the exterior contain them. The intestine, the moist surface of the mucous membrane of the mouth, nose, pharynx, and female genitalia, abound with them (117). They do not penetrate the tissues, but iive quite harmlessly in the secretions or excretions, the nature and composition of which determine the character of the bacterial 'flora' in each particular spot. Some species are constant inhabitants, others only occasional visitors, each kind multiplying and thriving where it finds the most suitable food, and serving perhaps as a protection against the invasion of other and perhaps pathogenic species.

Even the relatively dry skin of our bodies always holds spores and vegetative cells. Their character depends largely upon the occupation of the individual, and their number, as might be expected, upon the degree of cleanliness observed.

The bacterial flora of the mouth is very rich in species (118). About fifty have been described, some as accidental intruders, others as indigenous organisms. Although never absent, their numbers can be reduced very much by keeping the mouth scrupulously clean. As we have alrcady seen (p. I), their chief forms were known to Leuwenhoek.

Formerly all the bacteria met with in the mouth, whether cocci, rods, vibrios or spirilla, were classed together under one name. They were supposed to be different developmental stages of a single species, Leptothrix buccalis, which commonly occurs in the form of long unbranched cell-chains that sprout out from fragments of food, and from the contents of the tonsillar follicles. Such a view is of course incorrect, and the name $L$. buccalis must be used only as a collective designation for mouth bacteria. Some of these, such as Bacillus maximus buccalis (Fig. 26) and a coccus form (Iodococcns), give the granulose reaction. Others, such as Vibrio buccalis (Fig. 26, $g$ ), Spirochacte dentium $(f)$, and Leptothrix innominata, stain yellow with iodine.

Most of the bacteria of the mouth have as yet resisted all attempts 
at culture, and therefore the biochemical characters of the different species are unknown. This much, however, has been discovered, that the various kinds present, feeding upon the food particles remaining between the teeth, produce lactic and other acids, by which the enamel is decalcified in places. A path to the interior tissues of the tooth being now open, the bacteria bore their way, by means of their acid secretions, decp into the dentinal tubules, just as a lichen eats into stones. The organic substance of the tooth also is destroyed and the tooth becomes hollow and rotten. The following figures illustrate the effect upon the dental tissues:

$$
\begin{aligned}
& \text { Total Weight. Lime. Organic Matter. } \\
& \text { IS7.2 cubic millimetres healthy dentine. . } 0.36 \mathrm{gr} \text {. } 0.26 \mathrm{gr}=72 \% \quad 0 . \mathrm{I} \quad \mathrm{gr} .=28 \% \\
& 187.2 \text { cubic millimetres carions dentine. . } 0.08 \mathrm{gr} . \quad 0.02 \mathrm{gr} .=26 \% \quad 0.06 \mathrm{gr} .=7+\% \\
& \text { L.oss . . . } 0.2 \mathrm{Sgr} . ~ 0.24 \mathrm{gr} \text {. }
\end{aligned}
$$
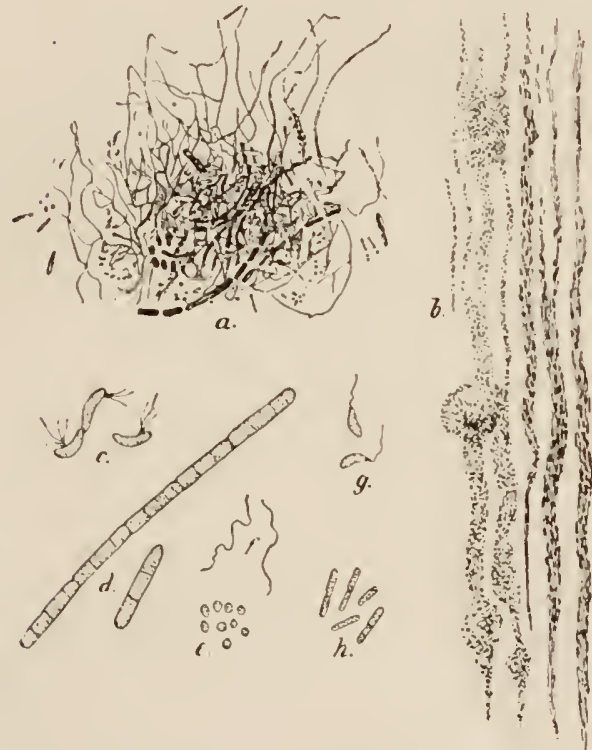

Fig. 26. Bacteria of the mouth and teetl. $a$, mass of mixed forms (from Miller); $b$, dentinal tubules filled and widened by bacteria, partly cocci, partly rods (from Miller); c. Spirillum sputigenum; d, Bacillus maximus buccalis, shows granulose reaction; $e$, cocci ; $f$. Spirochaete dentium: g, Vibrio buccalis; $h$, rods, probably lactic acid bacteria ( $B$, acidi lactici). 'Magn. $a$ about $250, b 400, c-h$ about 1200 .

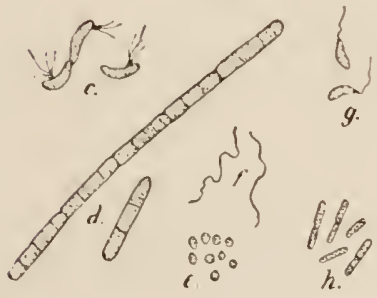

Thus the loss of calcium salts by the tecth caused by the acid secretion of the bacteria is 92 per cent., that of the organic substance 40 per cent.

Dental caries can hardly be looked upon as a 'disease'; it is rather the necessary consequence, sooner or later, of the action of micro-organisms that are normal inhabitants of the buccal cavity introduced daily with the food. The destruction of the teeth is not the work of any one species in particular, but due to the activity of several kinds.

Whence the bacteria of the mouth come is not at present known. The typical $B$. buccalis maximus is not found outside the body, and attempts at culture have been unsuccessful.

The discovery of bacteria, indistinguishable from those of our own mouths, in the hollow teeth of Egyptian mummies shows that these micro-organisms have been our companions from the earliest times.

The healthy stomach is, in consequence of the acidity of the gastric juice, not suitable for the development of a local bacterial flora. If however, as a result of illness or disease, the secretion becomes less acid or neutral, 
the bacteria and spores introduced with the food thrive and multiply abundantly. The Sarcinae which occur in almost every drinking-water are very prone to make their appearance. They include several species, which were formerly all classed together as S. acntriculi and supposed to be slightly pathogenic.

The richest hotbed for bacteria in the animal body is the intestine. Its contents are alkaline and the prevailing temperature is high and constant, so that putrefactive and fermentative bacteria of all kinds, both acrobic and anaerobic, find optimal conditions of existence. Fresh human faeces contain 75 per cent. water and about 1 per cent. bacteria. These include spores and rods of all kinds, among which may be often recognized the large cells of B. buccalis maximus that have been swallowed with food. It is calculated that from twelve to fifteen milliards of bacteria pass out of the body daily in the faeces (119). Many of them are dead, and stain very badly, others are still alive, and in some spores may be seen. As these spores have not been set free from the rods, there is no doubt they are of recent origin and formed in the intestine.

The nature of the putrefactive and fermentative changes wrought by the bacteria on the remnants of undigested food is, of course, dependent largely on the composition of the food. With a meat diet, putrefactive changes predominate, and products like tyrosin, leucin, indol, skatol, sulphuretted hydrogen, and ammonia arise (see $\mathrm{Ch}$. XI). With vegetable nourishment rich in carbohydrates, fermentation takes the upper hand, particularly the methane fermentation of cellulose. If the food and habits of the individual be regular, an intestinal bacterial flora of fairly constant composition arises, the leading species being generally the pleotrophic Bacterium coli commune (120) which is both zymogenic and saprogenic (Ch. XVI). Other species (e.g. B. putrificus coli) occur, but have not yet been thoroughly investigated. In the interior of the intestine, towards the middle of the mass that fills it, only anaerobic processes can go on, but at the sides, in contact with the mucous membrane, which itself is thickly covered with bacteria, aerobic changes can occur.

It is not necessary to discuss the means by which bacteria obtain entrance into the alimentary canal. We swallow myriads every day with our food, and it is only natural that they should multiply in the very favourable environment that the intestine affords. Their occurrence is a necessary consequence of their wide distribution in nature, and must not be taken as indicating a symbiotic connexion between them and their host. It has been imagined that they were perhaps useful auxiliaries in the process of digestion, but there is no foundation for such a supposition. We are fortunately not so miserably dependent upon bacteria as this. This has been experimentally proved by feeding new-born animals upon sterilized food (121). In this way it is possible to exclude bacteria, and 
kecp the intestinc germ-free for a considerable time, and the animals remain notwithstanding in perfect health. This would certainly not be the case if a symbiotic relationship subsisted between the bacteria and the organism. Such a view is contradicted also by the nature of the products arising from bacterial action. They are quite unfitted for resorption and utilization by the animal body.

The intestine of the new-born infant is absolutely stcrile (122), but bacteria make their appearance in a very few hours after birth, even before any nourishment is taken. No less than seven different species have been isolated from the intestine of children before feeding. The first to appear is the $B$. coli communne, which takes up its post at once in every mortal on his cntrance into the world, and remains his faithful companion until death. Whence this ever-present species comes is not known, but it is in all probability a metatrophic aquatic form. If infants be fed with the bottle the lactic acid bacteria appear at once in the faeces, and with cvery new kind of food new species of bacteria are added to the flora of the alimentary tract. As long as the mucous membrane is uninjured these bacteria are quite without danger for the body (123). Once let the continuity of the epithelium be destroyed however, even at a single point, and grave pathological changes may be set up, for among the hosts of metatrophic bacteria inhabiting the intestine some (c. g. B. coli) are facultative parasites and originators of disease.

It has long been customary to designate as 'infectious diseases' (124) all those in which the entrance of a certain 'something' into the body was a necessary condition for the cxistence of the complaint, this 'something,' the pathological 'virus,' playing a part in disease similar to that of the 'ferment' in the fermentation processes. Before we knew anything of bacteria it was usual to speak of a contagium when the disease could be transferred only by contact with a diseased individual, and of a miasma when the supposed virus could be carried by the air. And just as the discovery of the ferment organisms displaced the old conceptions of a lifeless ferment, so did the discovery, about the middle of the century, of a 'contagium vivum' take the place of the old ideas respecting the origin of infectious and epidemic disease. We now know that in the majority of infections the virus animatum is a bacterium.

The demonstration of bacteria in the blood or body fluids of a discased animal is an easy matter where large species are concerned, such as the anthrax parasite. These can be seen even in the fresh blood as pale rods lying about between the blood-corpuscles; in this way they were discovercd in 1850 . More minute forms, particularly cocci, which are easily confounded with albuminous granules from the blood, must be rendered visible by staining with aniline or other dyes. Diseased tissues must be fixed, hardened, cut in sections, and stained in order to rencler the bacteria in them 
distinguishable from other cellular clements (Fig. 27). Most of the various cytological methods used in investigating cell contents are applicable. The principles of bacteria-staining are not different from those involved in the staining of other cells, although in particular cases special technical processes are necessary to success. For these any of the numerous handbooks on bacteriological technique may be consulted.

The isolation of pathogenic bacteria from diseased organs is effected
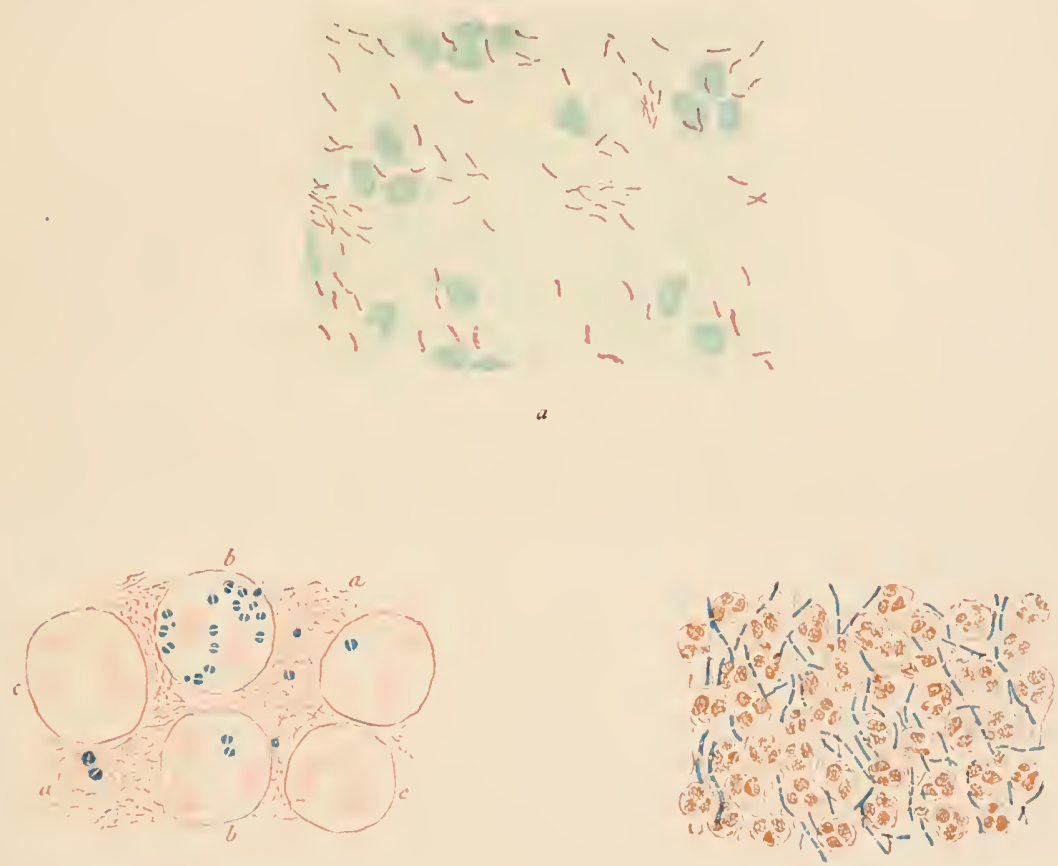

b

FIG. 27. Stained preparations of bacteria, fiom Ziegler's Lehrbuch d. allgein. Pathologie, 8th ed., vol. I. $a_{1}$ sputum of a consumptive, spread on a coverglass, and dried and stained with fuchsin and methyleue blue; the tubercle bacilli are rerl, cellular elements (pus cells) blue. b, Gonococci (Micrococcus gonorrhoeae) in fresh secretion, coverglass preparation : $a$, inucus with isolated cocci and pairs; $b$ and $c$, pus cells with and without cocci, methylene blue and eosin. $c$, section through an anthrax pustule (stained by Grain's metho(l), methylene blue and vesuvine. Magn. $a+00, b$ 700, $c 350$.

by the method of plate culture (p. $5^{8}$ ). In some cases, tuberculosis for instance, the centres of disease contain pure cultures of the spccific bacteria, and tubes of nutrient agar or gelatine can be inoculated direct. Much more labour is entailcd where the tissues contain a mixture of bacteria of different sorts from which the pathogenic species has to be separated and determined.

The requirements of pathogenic bactcria in artificial cultures differ 
according to the metatrophic or paratrophic habit of the germ. Strictly parasitic forms, such as the tubercle bacillus, diphtheria bacillus, and gonococcus, require the most nourishing media (see Chaps. VI and XVI). Long continued growth in artificial cultures weakens almost all pathogenic bacteria; decrease of virulence and morphological changes (involution) showing that nutrient media outside the body can never entirely replace the living tissues. The attenuation can be brought about and increased by many means (see p. 28) and, within certain limits, can be graduated with great precision. It is this possibility of varying the virulence of pathogenic bacteria that underlies a good deal of modern sero-therapeutics and protective inoculation.

The fact that the spores and dried vegetable cells of pathogenic bacteria are in many cases possessed of high powers of resistance renders it possible that the dried secretions and excretions of patients may become a source of infection for the healthy. The tubercle bacillus, for instance, is possessed of its full virulence even after lying for two, or even three, months dried up in dust. As far as the strictly parasitic forms are concerned the dry resting-stage is the only form in which they are met with outside the animal body. They have never been found growing and multiplying, for disease products are the only vehicle by means of which they are spread abroad and, once outside the body, even in situations that afford abundant food, they invariably succumb to the rapidly-growing. metatrophic species.

But of the many bacteria that are capable of causing pathological changes in the living tissues a large number are of metatrophic habit and able to thrive outside the body. Some grow quickly, others slowly, some have very humble requirements as regards food-stuffs, others are more pretentious, so that the ability to live saprophytically is very different in different cases. All of them, however, represent a much greater danger for mankind than do the obligatory parasites. Not only the pathological products, such as sputum or pus, are possible sources of infection, but all substances, such as milk or impure water, that offer a nutrient substratum and permit these metatrophic forms to multiply, become carriers of disease.

The detection and isolation of pathogenic germs from among a mixture of species, such as occur in contaminated drinking-water, is often enough a task of the greatest difficulty, and can be carried out successfully only by those who have had long familiarity in the technical details involved. In many cases experiments on animals are necessary to decide whether a given form is pathogenic or not.

Infection of the uninjured body by bacteria most frequently takes place in those organs which communicate with the exterior, particularly in those that, like the respiratory and alimentary tracts, are the passages 
or receptacles for substances taken into the body. They are the natural points of invasion and, as might be expected, they are furnished with means of defence against it. The epithelium of the stomach and intestine, the mucous membrane of the mouth, and the epidermis of the outer surface of our bodies-in short, every intact epithelial coat-scems to be impenctrable to bacteria. Even when highly virulent germs in large quantities are brought into contact with uninjured cpithelium, no infection takes place unless a certain unhealthy condition of the tissues, a 'predisposition,' prevails, and for the present this is unexplained. But where there is the smallest break in the continuity of the cells, there the bacteria can penetrate into the tissues and do their deadly work. We see this illustrated every day in wounds on the outer surface of the body, and there can be no doubt that it takes place in the same manner on the inner surfaces, the mucous membranes of the bronchi and intestines. And here it is instructive to recall what happens in plants. These close their wounds from below by impenetrable layers of cork and thus cut off from bacteria the fluids by which they are nourished. In animals, on the contrary, the blood and lymph that exude from a wound form a richly nutritive medium for the growth of the bacteria, which can then penetrate into the tissues and set up 'infection,' localized or general as the case may be. In experiments on animals we imitate the natural course of events by injecting the bacteria beneath the skin or into a blood-vessel. Insect stings represent a natural form of this injection and not infrequently inoculate the body with disease germs.

Investigations have yet to be made regarding the number of germs necessary to cause infection, particularly in the case of natural infections. In our experiments on animals the smallest doses must contain thousands of bacterial cells, but it is stated that of the anthrax bacilli ten are enough, injected hypodermically, to cause death in guinea-pigs (125).

When bacteria have penetrated below the skin there is always the possibility that they may be taken up by the blood-vessels or the lymphatics and conveyed to other parts of the body. If they are, they may either give rise to local lesions elsewhere or else endanger life by setting up general infection. Anthrax bacilli, for instance, may produce merely a local abscess (malignant pustule), or may spread and multiply in the bloodvessels all over the body. Pus cocci may give rise to little pimples or to the severer form of carbuncle, or scattered abroad by the blood may induce fatal pyaemia or septicaemia. Some bacteria derelop most rapidly in the blood (anthrax, spirilla of recurrent fever), others principally or entirely in the tissues (tubercle).

The fundamental phenomena underlying all infections are the same although the clinical and pathological features of a disease may be very different in different cases. For these aspects of zymotic complaints medical literature must be consulted. 
The relations between the cellular elements of the body and the invading bacteria are probably similar in all cases. Some bacteria are intracellular, that is to say, they live in the cell-substance, but the majority are intercellular, the destruction of the cells being a secondary process. The bacteria multiply in the secretions and exudations of the diseased tissue, pushing themselves in between the cells and into the spaces caused by the pathological softening and locsening of connective tissue. 


\section{CHAPTER XVI}

\section{BACTERIA IN RELATION TO DISEASE (Continued)}

\section{Description of some Pathogenic Species.}

THE following descriptions of some of the more prominent pathogenic bacteria will be confined to the general biological characters of the organism, purely medical questions being left to the specialist, who alone is entitled to discuss them (126).

We have seen that among the Saccharomycetes there has been exercised by mankind from the earliest epochs of civilization an unconscious process of selection, which has resulted in the production of innumerable 'races' or sub-species, distinguishable from each other only by minute physiological differences. A similar process has taken place among pathogenic bacteria. Disease and misery have been the lot of man from the dawn of time, and according to his liability to the attacks of certain species of micro-organisms, and the degree to which they have adapted themselves to life in the tissues, races and sub-species have arisen. Differing from one another by physiological peculiarities rather than by morphological characters, these varieties can often only be determined by resort to experiments on animals. In the case of some species that are known only from isolated cases of disease it is impossible even with the most subtle methods to attain certain results, and the difficulties are often increased by the existence of laboratory stocks (see Chap. III, p. 28) destitute of hereditary characters.

I. Cocci of Suppurative Processes (Figs. 28, $a-c ; 27, b$ ). By suppuration is understood the exudation from injured tissues of a fluid filled with wandering cells (leucocytes). It has been experimentally shown that suppuration can be produced without the agency of micro-organisms-for instance, by the application of nitrate of silver or corrosive sublimate; but there is no doubt whatever that all natural suppurative processes, from a sloughing wound down to the tiniest pimple on the face, are caused by micro-organisms. All the commoner pyogenic bacteria are cocci, but in spccial cases suppuration may be due to other forms, the typhoid bacillus, 
for instance, the bacterium of glanders, Actinomyces, and Bacillus pyocyanens, the bacterium of blue or green pus. The most widely distributed and at the same time most harmless form is Staphylococcus pjogcnes aureus (Micrococcus pyogenes). It is a chromogenic species that covers agar with an orangeyellow growth, and sometimes imparts a strong yellow tinge to pus (127). The cells are very small, on an average $0.8 \mu$ in diameter, colourless, and non-motile. They lie singly, or in pairs. or in short chains; more commonly still in little clusters (Fig. 28, a). Besides this orange-yellow form, a paler kind (S. pyogenes citreus) is known, and also a white one (S. p. albus). They are apparently distinct species, and, although having the same properties as S. aureus, are not so common. In nature the germs are found everywhere, so that they would seem to be metatrophic.

In disease they are most frequent in local suppurative processes, such as acne (inflammation of the sebaceous glands), sycosis (inflammation of the hair follicles), carbuncle, osteomyelitis, periostitis. Garré rubbed a pure culture of S. aurcus into his arm, and created thereby a severe carbuncle in which the bacteria multiplied abundantly. If from such local foci the bacteria spread, metastatic abscesses arise in other organs and in the joints, and the condition known as pyaemia results.

Another common pus bacterium is Streptococcus pyegenes (128). Of this species there are apparently several races very difficult of distinction. Both in the diseased tissues, and in bouillon cultures particularly, it forms long unbranched chains with cells somewhat larger than those of Staphylococcus (Fig. 28,6). The chains result from the planes of division always being parallel to one another. It is regularly present in erysipelas, and in many other pyogenic diseases. It is sometimes associated with Staphylococcus, which it exceeds in virulence. Like this, too, it gives rise to pyaemia and septicaemia if carried abroad by the blood. It is often present in diphtheria and in phthisis, increasing the severity of the malady, which then assumes the character of a mixed infection. In cultures, Streptococcus dies off much sooner than does Staphylococcus, often in a few weeks. This, and the fact that it is less common outside the body, indicate perhaps that it is a strictly parasitic organism.

The bacterium of gonorrhoea, the so-called Gonococcus (129), is certainly of exclusively paratrophic habit. Its artificial culture is only possible upon blood-serum, all other media, however nourishing, being useless. Whence the Micrococcus gonorrhoeae (Fig. 28, c) originally comes is not known, for it has never been found in nature, and perishes in a few hours when dried up. But it is a constant associate of the human race, and is transmissible only by contact. Since the temperature minimum is about $25^{\circ} \mathrm{C}$., and as the cells die within five hours in water, it is evident that a multiplication of the organism in swimming-baths is not possible. There is no danger of infection from this source. The gonococcus occurs in the inflam- 
matory secretion of the urethra, both in the cells (Fig. 27,b) and in the fluid. Thence it spreads to the epithelium and mucous glands, and finally to the other parts of the genital system. It may even extend all over the body (gonorrhocal rheumatism). The cocci lic usually in pairs, the stained cells being scparated by a clear unstained line where the mutually flattened sides are in contact. They are non-motile, and about the same size as staphylococci, from which, however, they are readily distinguishable by the paired grouping of the cells. None of the above-mentioned cocci are known to form spores.

A not infrequent cause of inflammation and suppuration in human beings is the 'Pncumococcus' (Diplococcus pneumoniac) of Fränkel, the usual cause of pncumonia (130).

2. Anturax (131) (Figs. 28, $d ; 27, c ; 5, \varepsilon, 7 ; 11, a, g ; 29)$. The anthrax bacillus ( $B$. anthracis) was discovered about the middle of the prescnt contury (in the early fifties) in the blood of cattlc suffering from splenic fever. It was detected in the form of colourless, motionless rods lying about between the blood-corpuscles. Although from the first suspected to bc the morbid agent, proof was not availablc until many years afterwards (1863). Through Koch's investigations into the life-history of the organism, anthrax or splenic fever has found its way into all the text-books as a classical cxample of a bactcrial infection. Koch followed the process of spore formation, and obtained the first purc cultures of the bacillus, commencing with this work his brilliant career as the founder of modern bacteriological technique.

The anthrax parasite is a comparatively large bacillus, cylindrical in shape, $3-6 \mu$ long by $I-5 \mu$ thick, varying within certain limits, as all bacteria do. Both in the blood and in the tissues single cells and ccll-chains occur (Fig. 27,c). In cultures the growth is chiefly filamentous, the plate colonics being as a result fringed with shaggy edges, loops, and curls of filaments stretching out into the gelatine. For the same reason stab cultures have a bristly appearance. The cells are non-motile, but form spores readily*.

The anthrax bacillus grows well in artificial cultures, but necds good sources of nitrogen and carbon; it is a peptonc bactcrium. There is, however, no doubt that it is not an obligatory parasite, but metatrophic, for it has bcen observed to grow well and form spores in cow-dung and earth. This indicates how the disease may arise in cattle, which are much more subject to infection than human beings. In man, infection generally takcs place from skin wounds, and the discasc remains localized, rarely spreading to other parts. In cattle, on the other hand, it is with food that the

* With regard tn spore formation, see p. 20 ; germination, p. 22 ; resistance to beat, p. 76 ; dryness, p. 77 ; poisons, p. 82 ; degeneration and attenuation, p. $2 S$. 
organism (probably spores, for the most part) is taken up. The spores pass uninjured through the stomach, and germinate in the intestine, setting up intestinal anthrax, which mostly leads to general infection and death. It is not known whether the bacteria have themselves the power of boring through the uninjured mucous membrane of the gut, or whether a previous laceration is necessary, such as might be caused by jagged splinters of food.

In small animals, such as mice, which succumb very quickly ( $\mathrm{I}-3$ days), the disease causes no conspicuous change in the organs, but in sheep and cattle its effects are more conspicuous. Spores, being formed only where there is free access of oxygen, never occur in the diseased tissues or the dead body. They arise under suitable conditions of temperature $\left(18^{\circ}-30^{\circ} \mathrm{C}\right.$.) in the bloody dejecta of sick animals, and also in carcases that arc not buried deeply underground.

3. Tetanus (132) (Fig. 28, e). Lock-jaw or tetanus is caused by a metatrophic bacterium very widely distributed in the soil, where it probably gives rise to various putrefactive and fermentative processes. The nature of these processes is in all probability dependent upon the food that happens to be available, for the tetanus organism is able both to split up sugar, and in albuminous substances free from sugar to decompose proteids into $\mathrm{CO}_{2}, \mathrm{SH}_{2}$, $\mathrm{CH}_{4}$, mercaptan, and free hydrogen. The pathogenic properties of the organism are duc, not to any of these substances, but to a violent poison which has not yet been isolated in a perfectly pure form. Tetanus is a typical traumatic infection that arises only by the contamination of wounds by matter containing the bacillus-earth or the dust of hay or straw, for example. The bacilli grow only in the wound itself, and even here but sparingly. They never spread to other parts of the body.

Bacillus (Plectridium) tetani is a slender motile rod $2.4 \mu$ long by $0.3-$ $0.5 \mu$ thick. It is inclined to filamentous growth, particularly in anaerobic cultures. In aerobic cultures the moss-like colonies grow only in the deeper layers of the gelatine. Before sporulation, which is very constant, the rods swell up at one end, and in this dilated part the spore appears. The drumstick shape, together with the peritrichous type of ciliation, places the organism in the genus Plectridium.

Two other bacteria of the soil with saprogenic and zymogenic properties (B. Chanvei and $B$. ocdematis maligni) give rise to quarter-evil and malignant oedema respectively.

4. Diphtheria (Bacillns diphtheriae, Loeffler; Corynebacterium diphtheriac, Lehmann and Neumann [133]; Figs. 28, $f$ and $14, h)$. This bacterium is found almost without exception in the outer layers of the diphtheritic false membrane. In consequence of this tendency to superficial growth, it seldom spreads to other parts of the body, but remains confined to those cavities which are the usual seat of the disease. Exceptions to this do, however, sometimes occur. It is often found in the throat in association 
with Streptococci, and in some few cases of apparently indisputable diphtheria it has seemingly been wanting. It is a true parasite, and in cultures requires the very best nutriment. Growing best upon blood-serum, to which has been added bouillon and sugar, it shows a tendency even on this medium to produce involution forms, although it multiplics rapidly. Irregularly swollen rods arise, and even cells with short branchings (Fig. 27). As was already mentioned, these have been without sufficient reason looked upon as representing a higher morphological stage than the normal rods.

In the diphtheritic membrane, and in fresh cultures, the bacillus appears as a minutc, somewhat clubbed or oval, rod-like cell about $1 \cdot 5^{-2} \mu$ long by $0.5 \mu$ thick. It is non-motile, and spores arc unknown. In young cultures the cell-contents stain apparently uniformly. Not infrequently strongly-tinged granules can be seen, and these when they are large and lie at the ends of the cell give the impression of spores. They are, however, nothing but 'chromatin' granules, such as have been already described. The apparently uniformly-stained cell-contents have the same structure

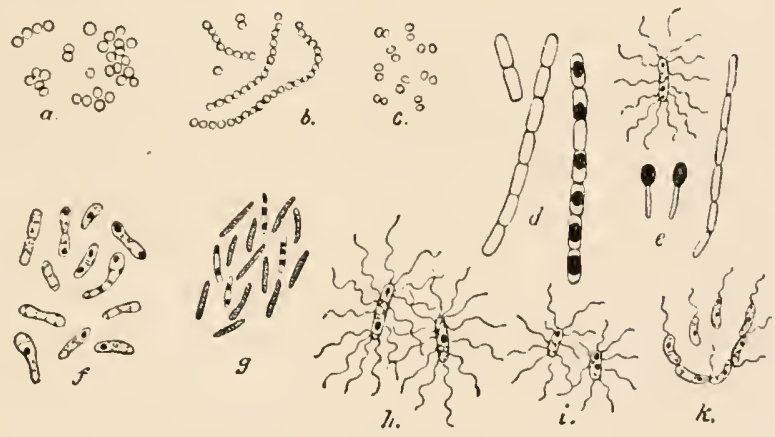

FIG. 28. Pathogenic bacteria. a, Staphylococcus pyogenes aureus (Micrococcus pyogenes); b, Streptococcus pyogcnes; c, Micrococcus gonorephoeae; d, Bac. anthracis; to the right, spore-bearing cells; $e$, Bacillus (plcctridium) tetani, motile rods, motionless chains, spores: $f$, Bacillus diphtheriae: some of the rods are clubbed, some contain large "chromatin' grains, and others show bands of shrunken protoplasm; $g$, Bac. tuberculosis, contents of some rods shrunk to granules as is often seen in sputum preparations; h, Bac. (Bactridium) typhi; $i$, Bac. (Bactridium) coli; $k$, Vibrio cholerae, single cells and chains. Magn. about 1500 .

as in other bacteria, the protoplasm surrounding a sap cavity which, as in all elongated forms, is divided into chambers by transverse walls of plasma. In old cultures the protoplasm diminishes in quantity, and the septa retreat from one another, so that the stained rods then appcar transversely striped (Fig. 28, $f$ ), broad, colourless stripes alternating with coloured plasma streaks. The actual structure of the cell does not change, but becomes more visible by reason of the changes mentioned.

The diphtheria bacillus is not found in nature, and as yet has been detected in a living condition only in situations where its derivation from human patients was certain-on soiled linen, floors and walls of rooms, children's toys, and the mouth and nasal cavity of those attending diphtheria cases. The dry cells remain infectious for many weeks. 
The fact that the diphtheria bacillus deviates in shape from the cylindrical renders it easily recognizable, but absolute proof of its identity is given only by experiment upon animals. The question of toxines and serum treatment will be considered in the next chapter.

5. TUBERCLE (Figs. $28, g ; 27, a ; 14, g$ ). The tubercle bacillus discovered and isolated by Koch is, like the diphtheria organism, a true parasite (134). Thanks to Koch's investigations, the demonstration and differentiation of the bacillus in sputum and diseased tuberculous tissues is now a matter of no difficulty, but the isolation and pure culture is still an uncertain and delicate operation. Even on the most suitable media, blood-scrum or glycerine agar at optimal temperature $\left(38^{\circ} \mathrm{C}\right.$.), the organisms grow excessively slowly, and need three or four weeks to form colonies as large as those produced by other bacteria in three or four days. It seems as though artificial media can never replace the living tissues of the host, and possibly we shall never succeed in getting the tubercle bacillus to grow more rapidly in our cultures. It may be, however, that a happy chance may show us some food, widely differing from the stereotyped media, that will offer optimal conditions to the organism. The fact that less 'nutritious' media, media with glycerine as a carbon, and ammonia as a nitrogen, source, permit slow growth, as do also potatoes and other vegetable media, may lead to further investigations.

In nature the tubercle bacillus has never been detected growing and multiplying, nor is it found in any situations where the possibility of contamination by tuberculous secretions is excluded. The commonest mode of infection for man is probably by the dried resting-stage, in which the organisms preserve their virulence for months. For children the use of the milk of tuberculous cows is a fruitful source of infection; the portal of infection in this case being the intestine. For adults the inhalation of tuberculous dust and the infection of wounds is the commoner occurrence. The infection of the lung is doubtlessly in all cases preceded and conditioned by a 'predisposition' which permits the inhaled bacteria to develop. Possibly minute lesions play a part in this. The so-called heredity of tuberculosis is in many cases undoubtedly nothing but heredity of the 'predisposition,' although infection of the embryo in utero has been observed and induced experimentally. Transportation of the bacilli by the spermatozoa is impossible, and infection through the ovum as yet unproven (135). Tuberculosis may attack any part of the body. The commonest form of the disease is pulmonary phthisis, but it frequently makes its appearance in the joints, in bones, glands, and other organs. Nodular inflammatory centres arise, which change later on into cheesy, necrotic masses. These contain enormous numbers of bacilli, the proliferation of which in the cells causes the degeneration and the other pathological changes that precede it.

The tubercle bacillus, like many other much-studied organisms, has been 
fated to receive several names: Bacillus tuberculosis, Koch, $188_{4}$, Sclerothrix Kochii, Mctschnikiff, 1889 , Mycohactcrium tuberculosis, Lchmann and Neumann, 1896 , Tuberculomyces, Coppen Jones, 1896 . It is a delicate, slender rod, often slightly curved, non-motile. The average size is from $1.5 \mu$ to $4 \mu$ long by $0.2 \mu$ to $0.4 \mu$ thick, but it is extremely variable in length and thickness, both in the tissues and in cultures, in both of which situations it sometimes appears in a filamentous form. On culture media it gives rise to thick, opaque, scaly or wrinkled membranous colonics of dry consistence. In consequence of the small size of the cell its fincr structure cannot be seen in detail (136). The cell contents, however, would scem to be denser than those of other bacilli, for the tubercle bacillus is much more highly refracting than any other species. It further differs from other bacteria in containing a large amount of true cellulose in its cell-wall. It is the greater density of the cell that cnables it to retain anilin dyes with such tenacity, a fact that facilitates immensely the detection of the bacillus in tuberculous material. In very old cultures, and sometimes in sputum, the bacilli often appcar as dotted, strongly-stained granules alternating with colourless spaces (Fig. $28, g$ ). We have already scen that this occurs in the diphtheria bacillus. In both cases it indicates a degeneration, and must not be regarded as a specific structurc-as a sign of sporulation, for instance. Real spores arc not yet known. The tubercle bacillus shows sometimes also another sign of the discomfort that genuine parasites undergo in artificial cultures. Involution forms arise-swollen rods and feebly-branched filaments-reminiscent of the bacteroids of Leguminosac (Fig. $\mathrm{I}+, g$ ), which have by some investigators been wrongly regarded as having morphological and systcmatic importance*.

Closely resembling the tubcrcle bacillus is the bacterium which is presumably the cause of leprosy. It has not been obtained as yet in purc cultures.

The bacteria already described can all be distinguished by their morphological characters, doubtful cases being confirmed by experiments

* The translator's observations do not pernit him to agree with this view. Accorcling to his investigations (Centr. f. Bakt., 1895 ), corroborated since by many other observers, the ramifications of the tubercle filaments are examples of true branching, and, together with the many other points of resemblance to Actinomyces, justify us in placing the organism among the filamentous fungi. The suggestion made in $18_{9}$, that a saprophytic form of the bacillus would probably be found outside the animal body, has also been fulfilled through the discovery, by Moeller (Therapeut. Monatshefte, Nov. 1898 ), of a bacillus almost indistinguishable from the tuberele bacillus growing upon Timothygrass. Several other saprophytic and parasitic organisms having the closest resemblance to Koch's 'bacillus,' but growing at low temperatures, have now been described, and leave little room for doubt that they, together with the organisms of mammalian and avian tubereulosis, are elosely related members of the same family. They show branched filaments in eultures, and when injected into the living tissues most of them give rise to actinomycosis-like centres of radiating filaments, terminating in elubbed ends (Zeitschr. f. Hygiene, vol. xxi, I S99). 
upon animals. The following species, on the other hand, are extremely difficult, and in some individual cases impossible to determine with certainty.

6. The Colon Bacillus (Bactridium [Bacillns] coli commune) is found constantly, and in large numbers, in the human intestine and in the excreta. It is in general nothing but a harmless commensal organism, but it may under certain circumstances become pathogenic both in animals and in man. The fact that a number of metatrophic bacteria very similar to $B$. coli are known makes its recognition very difficult, and it is moreover almost indistinguishable from the parasite of typhoid fever, Bactridinn typhi (Figs. 28 and 5). Endless pains have been taken to find reliable and constant points of difference between these two bacteria, and yet even now the differential diagnosis of the two species is a work of great delicacy (137). The very circumstance that the colon bacillus grows more quickly than the typhoid organism only adds to the difficulty, because in the attempts to isolate the latter from tissues or from water it is overpowered and choked by the rapidly-multiplying colon bacillus.

Common to both species is the rod-like shape (Fig. $28, h$ and $i$ ). The dimensions are about the same: $B$. typhi, I-4 $\mu$ long by $0.6-0.8 \mu$ thick, B. coli, $\mathrm{I}-3 \mu$ long, $0.4-0.6 \mu$ thick; i. e. B. typhi is rather the larger of the two. Both are actively motile and peritrichously ciliated. The cilia are too delicate for their number to be of determinative value. They do not liquefy gelatine, and spores are unknown in both species. In the absence of morphological differences, physiological peculiarities have been utilized. Such are, on the part of $B$. coli, the fermentative power, the production of gas, the acidulation and coagulation of milk, and the indol reaction when growing in peptone solutions. All these properties are absent in the case of the typhoid bacillus. Furthermore must be remembered the quicker growth of $B$. coli, and its more humble requirements as to food-stuffs. As was remarked on pp. 55, 56, this last peculiarity is deserving of special attention in differential diagnosis. It shows also that the $B$. coli, an 'ammonia bacterium,' is a very simple metatrophic organism, as is indicated by its frequent presence in dirty water. The typhoid organism, on the other hand, is paratrophic, and in all probability never occurs in potable water, except where introduced in the dejecta of typhoid patients. Such dejecta carry with them, of course, plenty of nourishment for the bacteria.

These few remarks will suffice to indicate in outline what we know at the present time concerning the biology of the typhoid parasite. In typhus abdominalis the bacilli can be demonstrated in all the abdominal organs (spleen, liver, kidney, lymphatic glands, \&c.), generally in little heaps between the cells, and also in the blood. Infection takes place undoubtedly from the intestine.

A species allied to the typhoid bacillus is B. typhi murinm, that was 
recommended by Löfler for the destruction of field mice, and has already been used with much success (138).

7. CilOlera. When Robert Koch returned in $188_{3}$ from his famed journey to India, the headquarters of cholera, having discovered the parasite that causes the disease, it seemed as though the recognition of the organism would in all cases be an easy task (139). It was the only pathogenic organism of its kind then known, a motile, curved, wriggling rod. But the occurrence of several European epidemics of cholera gave opportunity for more cxtended researches, and evidence was soon forthcoming on all sides, showing that micro-organisms similar to the cholera bacillus were to be found in almost all kinds of water. This fact must strike every one who makes a bacteriological examination of stagnant water (Fig. 22, b). Diligent search for physiological differences was made, but many of these, the growth in gelatine and the indol reaction, for instance, were soon found to bc unreliable. Whether the newest method, Pfeiffer's 'immunity reaction' (see p. 167), will fulfil the expectations it has raised, remains to be seen. Experiments on animals too must be elaborated in other directions than hitherto. Animals, even in India, are never attacked spontaneously by cholera. Guinca-pigs can be infected per os with the germs only after special preparation. If instead of passing through the natural portal of infection, the mouth, the bacteria be injected into the peritoneum, the animals dic, it is true, but only with the symptoms of gencral bacterial poisoning, and afford no clue which could serve to differentiate between the cholera germ and other aquatic vibrios. Even the bacteriological analysis of the cxcreta in suspicious cases is accompanied by great difficulties. For this reason all public announcements of the discovery of the germ should be regarded with a considerable amount of scepticism.

In true Asiatic cholera the characteristic dejecta (rice-water stools) contain enormous numbers of the Koch vibrios, the mucous flocculi discharged being practically pure cultures of them. They are confined to the intestinc, the wall of which remains gencrally intact, although it is occasionally invaded by the proliferating bacilli. They do not attack other parts of the body, as a rule being able to exert their full toxic power in the intestine, from which they disappear in non-fatal cases after onc or two weeks. Whilst the experience gained in epidemics is enough to establish the causal connexion between the bacilli and the discase, the result of laboratory infections and voluntary experiments afford conclusive proof. Pettenkofer and Emmerich (140) swallowed pure cultures of vibrios from the Hamburg epidemic and were attacked, the former slightly, the latter very severely, with cholcraic symptoms. That in cholera, as in all other infectious diseases, a certain something, a 'predisposition,' must be present before infection can take place, is self-cvident. In the case of cholera an important part is played by the diminution of the acidity of the gastric 
juice, and therefore of its antiscptic power, such as occurs from immoderate eating or drinking, or from climatic causes in summer. Every gastric or intestinal disturbance will be a predisposing condition.

The Koch 'comma' bacillus (Vibrio cholcrac, Figs. $28, k ; 2, c ; 5, d ; 6$, $a-c)$ is, like other vibrios, a minute curved, actively motile rod $(2 \mu$ by $0.4 \mu)$, bearing a cilium at one end. Occasionally two cilia are present, never more. On the surface of fluid media (bouillon or asparagine + sugar solution) the organism, being acrobic, forms thin membranes, and at the same time renders the underlying liquid turbid. Besides the more numerous single vibrios, long or short motile chains occur. These have been described as spirilla, but are really nothing but chains of vibrios joined end to end (Fig. 28, k). True endospores, although doubtlessly produced, are not yet known. Perhaps sporulation takes place only under tropical conditions of life. The structures found in old cultures that have been described as spores are only due to involution and granular degeneration of the cell-contents, as is evident from the extraordinary shapes of the cells.

The sporeless comma bacilli of our cultures can endure drying only for a very short time, perishing in a very few hours. A dry resting-stage as in the tubercle bacillus is therefore wanting, and infection from dry material impossible. As a metatrophic organism, however, it can live in water for weeks, and is by no means tied down to peptonized food-stuffs. The table on p. 55 shows it to be an ammonium bacterium that thrives well in glycerine sal-ammoniac solution if the reaction be suitable. Acidity arrests growth at once. These facts make it clear how the cholera germ is able to live and multiply in dejecta, on moist soiled linen, or in water containing putrescible substances. From albuminous compounds (in peptone broth, for instance) the cholera bacillus forms indol and other putrefaction products, while from sugar it can produce lactic acid.

From contaminated river or well-water used for drinking or for household purposes the bacillus reaches the stomach and intestine by way of the mouth. It is therefore of the highest importance that all drinking-waters should be under strict surveillance.

In its morphology and in its metatrophic mode of life the cholera vibrio resembles our indigenous European aquatic vibrios (141), and in summer it is, like them, able to live in rivers and ponds. It is, however, originally a tropical organism, its native place being the East Indies, where it lives in foul water just as its relatives do with us. Under such circumstances only a high temperature, $30^{\circ}-40^{\circ} \mathrm{C}$., is necessary to permit it to thrive and develop its virulence. This condition is present in our climates in summer. Some of our indigenous vibrios, $V$.berolinensis and $V$.danubicus, can develop pathogenic properties, but it is not known whether they are ever the cause of disease in human beings. That the tropical species are the more virulent 
is in harmony with the well-known fact that vegetable poisons are alway's stronger in the tropics than in temperate climates-the hashish of hemp, for cxample.

We sce from the above facts that cholcra is caused by a tropical aquatic organism, a metatrophic bacterium, which is not able to obtain a permanent footing in our climate, but is introduced afresh from time to time through the various channels of trade and communication.

8 . In addition to the well-known species of pathogenic bacteria already described, there are many with which we are less familiar, the spirochacte of relapsing fever, the glanders bacillus, swine crysipclas, and other animal infections. In many diseases, such as rabies, scarlet fever, measles, whooping-cough, the specific organisms, although supposed to be bacteria, are not yet known. A few other pathogenic micro-organisms and fungi were mentioned in Chapter IV. 


\section{CHAPTER XVII}

\section{BACTERIA IN RELATION TO DISEASE (Contimued)}

\section{Mode of Action of Bacteria, and the Reaction of the Organism. Serum Therapeutics and Immunity.}

WIIEN bacteria by one means or another have obtained entrance into the body, there elapses before the outbreak of the disease a certain interval, the period of incubation. In the guinea-pig, after infection with Streptococci, from fifteen to sixty hours pass before symptoms begin; after infection with cholera germs, from one to three days; in human beings the period of incubation for anthrax is three to seven days, for syphilis, three to four weeks, for rabies forty days or more. During this time the invading bacteria are multiplying and struggling for mastery with the invaded organism. The struggle may go on without any outward signs at all, or it may be accompanied by slight disturbances of health. If the tissues conquer at the very commencement, the disease never breaks out. It is quite possible that many a temporary indisposition and fleeting local pain may be the expression of such a conflict, in which the defeat of the bacteria prevents the onset of grave illness, for it is certain that pathogenic bacteria enter the body far more often than the number of actual illnesses we are subject to would lead us to suppose.

But if the first attempts at defence on the part of the body are futile, and the bacteria are able to multiply, then the disease breaks out and severe symptoms show that the struggle between host and parasite has become more intense. Of these symptoms it is now no longer possible to say which are measures of defence on the part of the tissues, and which are signs of defeat.

A weakening of the body through the abstraction of nutriment by the bacteria is hardly possible, for the micro-organisms, even when multiplying 
abundantly, could take up only a minimal amount of substance. But if metatrophic ferment or putrefactive bacteria invade the body they would break up not merely their own bulk of organic substance, but a hundred or a thousand times as much. As a secondary aggravating effect, such changes must not be overlooked in bacterial infections; they may, for instance, cause destruction of tissue.

Bacteria may, from purely physical reasons, cause local disturbances of the circulation by accumulating in the capillaries. This happens in anthrax, where the vessels are for short distances completely plugged by the bacilli.

These effects of bacterial intrusion, to which formerly great importance was attached, are now looked upon as merely subsidiary phenomena. The violent symptoms and serious consequences of a bacterial infection are now known to be due to the action of toxines, poisons produced by the microorganisms.

The contagium animatum that invades the body from outside produces in the tissucs the airus inanimum, the lifeless poison. The investigation of these poisons is now in full progress, but, as may be readily conceived, is attended by great difficulty, for they are all of them extremely unstable bodics, and many are of proteid nature, and therefore less accessible to the ordinary methods of chemical research. It is certain that they include substances of very various chemical composition.

The oldest known group is that of the ptomaines or putrefactive alkaloids, so called on account of the resemblance of their chemical reactions to those of vegetable alkaloids. They play, however, only a very small part in the toxic action of pathogenic bacteria. The isolation of the actual specific toxines (142) from the cultures has been attended with but little success as yet, in spite of the great amount of labour that has been spent upon the subject, and we speak of the 'toxines' without really knowing them in a pure statc. But to have them chemically purc, although very desirable, is not absolutely necessary, as the following description shows. To separate the poisons dissolved in the culture fluids from the bacteria, it is sufficient to filter bouillon cultures through porous earthenware or kieselguhr. If the poisonous filtrate thus obtained, for instance from tetanus cultures, be injected into animals, they die with the same symptoms of lock-jaw as if they had been injected with the bacilli themselves. In the same way the filtrate of diphtheria cultures kills the animal with the symptoms of diphtheria. In short, it has been shown that all pathogenic bacteria produce soluble poisons, that these poisons alone are able to give rise to the discase, the nature and course of which depend solely upon the nature of the toxines. Old cultures in particular contain large quantities of toxines; they are highly 'poisonous,' whilst the younger growths are distinguished by the more rapid growth of the micro-organisms-they are 
more 'virulent'*. The filtrates can be concentrated by evaporation in s'acuo, and much more powerful toxic solutions obtained. By treatment with alcohol or neutral salts, solid precipitates of still greater toxicity can be gained. These precipitates contain of course a mixture of different substances, albumens and albumoses from the bouillon, and inorganic constituents besides the toxines. A complete isolation of the latter has not yet been possible. They were formerly supposed to be proteid bodies (tox albumines), but further purification has shown that they may possibly be of simpler structure. They are extremely poisonous, one twenty-thousandth part of a milligramme $\left(=\frac{1}{-0,000,000}\right.$ gram. $)$ of a concentrated tetanus toxine being sufficient to kill a mouse. For a human being $0.23 \mathrm{mg}$. would probably suffice.

The poisons contained within the bacteria (intracellular toxines) can also be extracted. The best known example of these is Koch's tuberculin (143), a purified glycerine extract of tubercle bacilli. Pure toxines have not yet been obtained by this method; the tuberculin of 1890 contained, in addition to the unknown toxine albumens, albumoses and peptones from the culture media. The newest tuberculin preparations too, Koch's $\mathrm{TR}$ and $\mathrm{TO}$, are extracts of dried and pounded bacilli from highly virulent cultures. The finely pulverized bacilli are centrifuged in distilled water. The first clear yellowish extract is the $\mathrm{TO}$ and has properties resembling those of the old tuberculin. Repeated centrifuging of the sediment of TO gives the more effective TR. Both $\mathrm{TO}$ and $\mathrm{TR}$ are mixed with 20 per cent. glycerine to assist their preservation. They are nothing but virus-containing mixtures of all the soluble constituents of the tubercle bacilli together with fragments of the crushed cells.

Both the bouillon filtrates and the precipitated toxines retain their virulence for a long time, but they are very sensitive to high temperatures and alkalies or acids. Tetanus toxine is destroyed in a few minutes at $65^{\circ} \mathrm{C}$., diphtheria toxine in two hours at $58^{\circ} \mathrm{C}$. This instability, although suggestive of the properties of enzymes, must not be regarded as indicating a relationship of the two classes of compounds.

Just as the poison of serpents or the alkaloids of poisonous plants are the products of the vital activity of those organisms, so are the toxines products of bacterial life. They are excreted from the bacterial cell during life, and are poured into the culture fluids in abundance when the cells die; hence the great poisonousness of old cultures. As the microscope shows us, too, that bacteria often become disintegrated in the tissues, they may evidently contribute in this way also to the poisoning of the body.

* Translator's note. These terms have been translated just as they stand in the German, where the meaning is clear; but they can scarcely be regarded as good English, unless the word virulent is allowed to connote the power of multiplication possessed by the organisms. 
The fact that screral species of fossil bacteria are known from the carboniferous and other periods (144) shows that they are among the oldest inhabitants of the earth, and were already widely distributed when the Tertiary Epoch and the evolution of warm-blooded creatures began. We should therefore expect that these would, in the course of their phylosenetical progress, have gradually developed the power of resisting the attacks of the invading micro-organisms.

The investigation of these protective propertics is the subject of $\mathrm{cx}$ tensive rescarch and has already, in the field of scro-therapeutics, borne fruit that promises much for the future, although it is true that at present experience and thcory are opposed to each other on many points, and a long time must clapse before a reliable foundation is reached.

The first of the defensive appliances of the body to which attention was directed (mainly by Metschnikoff and his followers) were the white blood-corpuscles or leucocytes, the important part played by which in physiological and pathological processes has come to be more and more recognized. These naked cells that have their origin in the spleen, the bonc-marrow, and other haemopoeic organs of the body, are often called 'wandering cells,' because they are able to leave the blood-vessels and lymphatics in which they are distributed over the whole body and penetrate between the fixed cclls of the
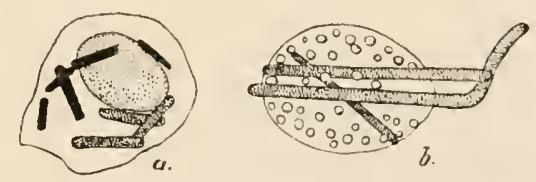

FIG. 29. Phagocytosis, from Metschinikoff. $a$ leucocyte from pigeon's blood with anthrax bacilli. These are in some cases intact and stain well (black), in others degenerate and pale. The oval body is the cell nucleus. $b$, a living leucocyte from a pigeon, devouring anthrax bacilli. tissucs. They are found, for instance, actively multiplying in the intestinal villi during digestion, and as 'puscorpuscles' they constitute the chicf part of pus. An increase of them in the blood-vessels is spoken of as leucocytosis.

Now in the blood of animals infected with anthrax, and in suppurative processes of all kinds, the leucocytes frequently (although not always) contain bacteria. These are sometimes present in great numbers, and often appear to be dead, inasmuch as the cell-contents are changed and stain badly (Fig. 29, $a$ and $b$ ). On these phenomena Metschnikoff founded his theory of Phagocytosis (145). The wandering cells were supposed to function as pleagocytes (devouring cells), to take up and to kill any bacteria that had penctrated into the tissucs. They were supposed, in fact, to constitute an army of defence that could be mobilized and sent to any part of the body. This vicw, the result of direct observations, was further strengthened when the chemotactic propertics of leucocytes (153) were studicd, and, above all, their bchaviour towards bacteria and towards the products of their metabolism contained in purc cultures.

Capillary tubes filled with bacterial substances, introduced into the FISCHER 
tissues, were found after a short time to be p'ugged full of leucocytes. The immigration of these was attributed to chemotaxis, sometimes, it is true, without due consideration of the necessities of Weber's law (p. 80). Since bacterial foci in the tissues are almost always surrounded by a crowd of leucocytes, and since these are laden with bacteria, Metschnikoff's theory seemed well founded.

There was, however, a discovery made respecting the serum of the blood that seemed to show that phagocytosis was neither the only, nor the most important, means of defence that the body possesses against invading bacteria. If bacteria were mixed with blood-serum and this serum examined from time to time by the plate culture method, it was found that fewer and fewer colonies of bacteria arose, until, after an interval of some hours, the serum was sterile, the bacteria being all dead. This bactericidal influence of blood-serum, which is apparently exerted upon all bacteria, is destroyed by the addition of distilled water or by heating the serum for an hour to $55^{\circ} \mathrm{C}$. According to Buchner it is due to certain substances, alexines (146) (defensive substances), which, like the toxines, are very unstable, and have not yet been obtained in a pure state. Seeing that serum which has been rendered inactive by distilled water can be restored to bactericidal power by the addition of 0.3 per cent. $\mathrm{NaCl}$ or other salts, there is evidently many a mystery hidden in the 'alexines.'

In the early eighties, when the alexine theory and the theory of phagocytosis were in sharp opposition, most weight was laid upon the destruction of the bacteria. Afterwards, however, the toxine theory of infection (142) was brought forward, and the question arose as to the neutralization of bacterial poisons and the presence of 'antitoxines.' Since bacteria of the most various kinds could be destroyed by one and the same poison, it was not necessary to assume the existence of specific alexines. The different toxines, on the other hand, seemed to require different antitoxines, just as almost each different poison requires a specific antidote.

Since the animal body is the most delicate, and at present, indeed, the only reagent we possess for bacterial toxines (which, moreover, we do not know in a pure state), it is evident that the antitoxic properties of the blood-serum can only be investigated by means of experiments on animals.

As in the case of the bacterial poisons, it has not yet been possible to isolate the antitoxines. They are said to be somewhat more resistant than the toxines. But the statements of different investigators differ even as regards the same antitoxines, since they can be examined of course only in a dissolved state in the serum.

Since the cell-free serum of the blood is a lifeless fluid, we are forced to regard the leucocytes as the producers and carriers of those substances 
which give the serum its bactericiclal and antitoxic propertics. Alexines and antitoxines are products of the leucocytes, which fight against the bacteria more by means of these substances than by virtuc of their phagocytal functions. This way of looking at the matter effects a compromise, that is already widely recognized, between the theorics of Metschnikoff and the French school, and the German doctrinc of antitoxines (147).

Another natural means of defence against bacterial poisons possessed by man and all other organisms is the power of acquiring toleration of poisons. It is incleed only a special case of the ability possessed by all living substance to accustom itself to external influences when these increase slowly and do not exceed a certain degree. It is well known that this power is highly developed in some organisms and is subject to great individual variation. We only need recall the acclimatization of animals, of plants, of the races of mankind, and even of bacteria themselves, living as these do in pure cultures under conditions totally different from those of their native haunts. Instances of habituation are familiar enough; arseniceaters are able in time to endure $\mathrm{C} .4$ gram of arsenic at once, the fatal dose being ordinarily from 0.1 to $0.2 \mathrm{gram}$. Morphinomaniacs accustom themselves gradually to four times the fatal dose ( 0.4 gram per os).

By very gradual augmentation of the dose white mice have been made immune to ricin (the poison of the castor-oil seeds), so that they were able finally to stand one hundred times the fatal dose without injury (148).

The body can also accustom itself to the toxines of pathogenic bacteria, and it will be found worth while to review from this standpoint (neglecting for the time being the antitoxine theory) some of the innumerable observations that have been made during the last ten years in the fields of immunity and serum therapeutics. For instance, in order to make a guinea-pig actively immune to diphtheria poison, one proceeds as follows (149). First of all the minimal lethal dose of a virulent filtered bouillon culture is determined; i.e. the number of cubic centimetres which suffice to kill a guinea-pig when injected subcutaneously. Perhaps 0.3 c.c. per kilo. body-weight is cnough; i.e. for a guinea-pig of 250 grammes about 0.08 c.c. This quantity is naturally not a fixed amount, comparable to a normal solution used for volumetric analysis; it changes according to the virulence of the bacilli. One then begins by injecting a guinea-pig with a much smaller amount, $0.00 \mathrm{I}$ c.c. for instance, which perhaps causes only temporary sickness. Then the dose is gradually and continually increased until at last an amount far exceeding the fatal dose can be borne without injury. The animal has become immune to the poison. In this way, too, horses are immunized for the preparation of Behring's diphtheria serum. Instead of minute doses of a highly toxic filtrate, larger doses may be employed of a filtrate whose virulence has been weakened either 
by heat $\left(50^{\circ}-70^{\circ}\right)$ or by the addition of chemical substances such as trichloride of iodine or carbolic acid. Finally, inoculation with the attenuated bacteria themselves may be resorted to. All the methods lead to the same results, and the principle involved in each case is the same, for the treatment of bacteria with substances that hinder their vegetative development naturally reduces also the amount of poison they produce. It was the method of immunizing by means of weakened pure cultures that formed the starting-point of the treatment with the toxines themselves. Behring (150), by using tetanus bacilli that were attenuated in different degrees by iodine trichloride, was able in about seventy-five days to immunize a horse to such an extent that it endured the injection of 100 c.c. fully virulent tetanus culture. An untreated animal was killed by 0.5 c.c. of the same culture. To attain this degree of immunity several hundred c.c. of attenuated cultures were necessary. It took to render a horse highly immune to diphtheria eighty days and eight hundred c.c. of filtered virulent diphtheria toxine (151). It could then be tapped for curative serum. By continued treatment the resistance to virus can be still further increased and persists for a considerable time. In tetanus-immune horses the immunity lasts two years, and in diphtheria-immune horses about the same time. In experiments with other bacterial poisons the immunity attained was not so persistent, although enduring many weeks or months. Variations are unavoidable.

Assuming that artificial immunity is only the acquired toleration to the poisons, its disappearance would be explained by the poison gradually leaving the body and finally disappearing entirely. The cells of the body would thus gradually lose their power of toleration. The fact that the immunity lasts two years and more is no argument against this, for we know that some poisons are excreted from the body with great slowness; mercury, for instance, does not disappear for six months or more after administration. Immunization by injection of toxines must be regarded as an experimental chronic intoxication.

Such an artificially-induced immunity protects of course not only from the direct administration of the poison, but also from the virus excreted by invading bacteria. Tetanus bacteria, for instance, are not arrested in their growth by the antitoxine, but their poisons are neutralized. The same takes place in diphtheria (152), while in other diseases it is not yet clear whether the neutralization of the poison is not accompanied by arrest of growth of the bacteria (Cholera, p. 167).

The immunity produced is strictly specific; the diphtheria poison, for instance, imparts immunity only against diphtheria, not against tetanus or anthrax, or any other infections. This again can be easily explained by toleration, which is in fact competent to account for all the phenomena which the immunized animal exhibits in its own organism. Towards other 
organisms, however, the immunized animal shows new properties which underlie the practice of serum therapeutics. By injecting the serum of immunized animals into other untreated individuals these too can be made 'passively' immune, and be caused to share in some degree the propertics of the serum-giver. The milk also of immunized animals has the same power as the serum, although to a less extent. The milk of diphtheriaimmune goats, for instance, possesses from one-fifticth to one-thirticth the immunizing strength of the blood-scrum of the same animal (153). Numcrous experiments upon animals have shown that an immunized mother can impart her immunity to her offspring. This inherited immunity is not lasting, but disappears in two or three months. Immunity is not transferable by the father (154).

All the phenomena exhibited by immunized animals can be cxplaincd without the assumption of 'antitoxines,' mercly by supposing that the toxines that have been introduced into the blood leave the body very slowly, not disappearing entircly for inonths or even years. As long as minute quantities of toxines remain the animal is immune, although its immunity is steadily decreasing. And these remainders of toxine in the serum induce immunity when injected repeatedly into other animals. The higher the doses to which the serum-yielding animal has been subjected the greater amount of toxine will its serum contain. The toxine may accumulate to such an extent that the animal itself may die of poisoning, although its serum has reached the highest degree of immunizing power. This hyper-sensitiveness which has been observed by Behring (155) is quite inexplicable by means of the antitoxine theory, but can be accounted for without difficulty by the toleration hypothesis.

If the effect of the curative scrum depended only upon the introduction of very dilute toxines, we should expect that it would be greatest before the incorporation of the infecting germ, inasmuch as toleration would have been established before the disease broke out. Wide experience has shown, however, that good results follow the injection of cither the protective scrum plus the cell-free toxines, or the serum plus the bacteria simultancously or one after the other. Here again a plausible cxplanation is possible without bringing in the antitoxine theory. It is conceivable that the toxine in the serum of toxine-tolerant animals is more easily absorbed than the fresh toxines in the bouillon filtrates, and gets into action before the latter (156).

It may be argued that if frec toxine were the immunizing agent in the serum the same symptoms must arise from a scrum injection as from the injection of a toxinc. As a matter of fact we find that the injection of scrum is not borne by the organism quite without signs of reaction. Often enough, as is well known, there are violent secondary symptoms, and, inasmuch as the amount of toxine, even in the most effective serum, must be very small, it is not necessary that distinct reactions should arise. 
These arguments, it is true, do not give anything like a complete explanation of the phenomena, but they show how far we can go without assuming the existence of specific antitoxines, using in their place the phenomena of toleration, phenomena which are, it is true, still unexplained.

As soon as we grant the existence of antitoxines, another mysterious property of the organism has to be assumcd, namely the ability to produce a specific antitoxine for each kind of toxine, and possibly for every other poison. Theoretical medicine is at present strongly inclined to explain immunity and serum therapeutics by such antitoxines. By the incorporation of poisons the body is stimulated to produce antidotes; these increase as immunity increases, and are the effective agents in the serum. Serum therapcutics and serum immunity consist in the introduction into the organism of 'anti-substances.' These substances are, as we have seen, as yet quite unknown, and opinions are divided as to their manner of action, whether they neutralize the poison by chemical combination or only stimulate the body to greater resistance.

The theory of 'anti-substances' is also involved in the terminology which is used by Behring and Ehrlich (158) to designate the various strengths in which the diphtheria serum is sold. By a 'normal' toxine is understood a filtered virulent diphtheria bouillon culture of which 0.3 c.c. suffices to kill a one-kilo. guinca-pig when injected subcutancously. For an animal of from 200 to $300 \mathrm{grm}$. O.I c.c. would be enough. A normal antitoxic unit is a solution of antitoxine of which 0.1 c.c. destroys the virulence of I c.c. normal toxine, i.e. sufficient to protect a guinea-pig from ten times the fatal dose. This of course can only be determined by experiments on animals, toxine and antitoxine being injected together. Therefore to makc a guinea-pig immune against the lethal dose of o.1 c.c. normal toxine, $0.0 I$ c.c. of the normal antitoxine is necessary. Normal serum contains in I c.c. one 'antitoxic unit,' and therefore I c.c. of such a serum is sufficient to protect ten guinea-pigs against the fatal dose (157).

The therapeutical and clinical questions involved in the serum treatment cannot of course be discussed here. A mature and final judgement as to its efficacy will not be possible for many years (159).

A theoretical explanation of the phenomena of immunity is rendered very difficult by the distinction that has been supposed to exist between bactericidal and antitoxic action. While it is generally admitted that protection from diphtheria and tetanus is caused by 'antitoxines,' that is to say, by substances that destroy the poison of the bacilli, it is asserted that in artificial immunity against cholera, typhoid, and some other diseases, the chief part is played by bactericidal substances. The bactericidal effect is said to be specific in each case. Pfeiffer's cholera-serum reaction, the meaning of which is at present the subject of a good deal of discussion, may here serve as an example of these phenomena (160). 
To immunize a guinea-pig against cholera, dead bacilli are injected into the peritoneum, and afterwards living virulent bacilli in gradually increasing doses. By these means the animal is rendered immune and its serum can be used for showing the specific reaction. If about 30 milligrams of this serum be mixed with a fatal dose of virulent bacilli, and the mixture be injected into the peritoneum, no ill effects are produced. The bacilli are destroyed by the serum. They become clumped together, lose the power of movement, and break up into granules. Outside the body, too, in a hanging-drop preparation under the microscope the process can be seen. The bacilli become motionless, stick together, and undergo granular degreneration. According to Pfeiffer it is strictly a specific reaction which can be used to differentiate the cholera bacilli, no other bacteria, not even the vibrios, behaving in this way. The facts have not been received without some scepticism, and the reliability of the reaction is by no means universally recognized. The isolation of the active substance in the serum has not been accomplished any more than in the case of other antitoxines. Seeing that 'a serum which had been putrefying for months retained its specific activity almost unweakened' (161), it is evident that the 'antibacterial ' bodies must have the stability of mineral substances, and be very different from antitoxines and all other products of the animal body. The facts that the cholera bacilli in a hanging-drop culture finally recover from the paralyzing effects of the scrum, and that pure diluted normal serum of pigeons undergoes a very similar granular degeneration, show us that we must be cautious in forming an opinion. The whole phenomenon has a very suspicious similarity to plasmolytic changes, such as might well be caused by the salts of the serum or of the bouillon (Fig. 6, p. 8).

The observations cited do not, of course, embrace all that a theory of immunity has to go upon, but they are the chief data. By immunity has always been meant insusceptibility to a disease-the power of resisting an invading contagium. According to recent discoveries we must distinguish between an immunity to the bacteria and an immunity to their toxines. Furthermore, a distinction must be drawn between natural or congenital, and acquired immunity. Cold-blooded animals, for instance, are immune to the diseases of warm-blooded ones, our domestic animals are immune to cholera, the dog to small quantities of anthrax bacilli. Individual variations occur as might be expected. We see it in man where a personal immunity seems often to exist, and must probably be regarded to some extent as a matter of 'predisposition.' The age of the individual, too, brings changes in the natural immunity, as is shown by the existence of children's diseases. Perhaps these are 'immunity diseases' intended to prepare and fortify the young mortal against bacterial enemies to come, but the question cannot be discussed here.

Immunity can only be acquired by a pathological change, be it by the 
natural attack of a disease or by artificial inoculation of it. The oldest protective inoculation, Jenner's vaccination for small-pox (discovered 1796), started from the observation that an attack of cow-pox producing only slight symptoms of disease protected human beings from the dangerous variola. Up to the present day we know neither the organism of vaccine nor the active principle of vaccine lymph. In the case of rabies, too, for which Pasteur (162) introduced a protective inoculation with weakened virus (dried tissues of rabid animals), the cause of the disease is not known. For these two kinds of inoculation which formed the starting-point for all modern investigations on protective inoculation we are still unable to give any exact explanation.

It was Pasteur, too, who introduced the methods of protective inoculation for anthrax, which have been of such value in France. The practice has resulted in reducing mortality from anthrax in cattle from 5 per cent. to 0.3 per cent., and in sheep from ro per cent. to I per cent. (163).

In spite of garrulous indiscretion on the part of certain people, and the dishonest cupidity of others, Koch's tuberculin inoculations (134) must always have the credit of being the first method in which bacterial products were used, and not the bacteria themselves, as in Pasteur's anthrax inoculations, nor an uncertain 'something,' as was the case in vaccination. Koch's method formed the basis of all the innumerable investigations that have followed it, including Behring's method of serum treatment, which, as we have seen, is at bottom nothing but the injection of toxine-containing serum.

To formulate a theory of immunity that shall not be lost in clouds of hypothesis is at present impossible. The alexines, antitoxines, lysines, and antilysines, that the wordy research of the last few years has given us, are at present quite unknown (164). The inextricably complex inter-relations of the antitoxic and antibacterial properties of the body-fluids have not yet been cleared up, and even the effect of normal blood-serum upon bacteria is but imperfectly understood. And the greatest difficulty of all is to explain the long persistence of immunity after recovery from natural attacks of infectious diseases. 


\section{NOTES}

1. (p. I). Axton v. Leeuwenhokk, Arcana naturae detecta. The figure dates from the year $16 S_{3}$, and is taken from a new edition of the Arcana published in 1722 (vol. ii. p. 40).

2. (p. 2). ROBERT KOCH, Kreisphysicus in Wollstein, Die Aetiologie der Milzbrandkrankheit, begrïndet auf die Entwickelungsgeschichte des Bacillus anthracis; I876. Beiträge z. Biol. der Pflanzen, herausgegeben von Ferdinand Cohn, vol. ii.

3. (p. 2). Of newer general works may be mentioned: FLüGGE, Die Mikroorganismen (Engl. transl. publd. by the Sydenham Society), 3rd ed. I896. LEHMANN and NeUman, Atlas and Outlines of Bacteriology, IS97. For the fermentation organisms, Lafar, Technische Mykologie, I897 (English transl. I898). Up to the present only vol. i (Schizomycetes) has appeared (see note 126).

Full references to bacteriological papers will be found in BAUMGARTEN'S Jahresbericht über die Fortschritte in der Lehre von den Gärungsorganismen, and in the Centralblatt $\mathrm{f}$. Bakteriologie. This appears in two sections: ( 1 ) medical and hygienic bacteriology, and (2) general agricultural and technological bacteriology, physiology of fermentation, and phytopathology.

The literature of the French school will be found in MACÉ's Traité pratique de Bactériologie, 2nd ed. I891.

4. (p. 2). LöfFLER, Vorlesungen über die geschichtliche Entwicklung der Lehre von den Bakterien. Part I, up to the year I878 (all that has appeared), Leipzig I 887 .

5. (p. 4). A synopsis of researches on the structure of the bacterial cell and original observations will be found in BüTschLI's Weitere Ausführungen über den Bau der Cyanophyceen und Bakterien, Leipzig $\mathbf{1} 896$, and in A. FISCHER's Untersuchungen über den Bau der Cyanophyceen und Bakterien, Jena 1897.

6. (p. 12). For the classification of the pigment bacteria here adopted see BEYERINCK, Die Lebensgeschichte einer Pigmentbakterie, Botanische Zeit. 1891; and also Schroeter, Ueber einige durch Bakterien gebildete Pigmente, Cohn's Beiträge z. Biol. vol. i.

7. (p. 12). Details as to the assimilation of these green bacteria (which are perhaps ininute green algae, Protococcaceae) may be found in Engelmann, Zur Biologie der Schizomyceten, Bot. Zeit. I 882.

8. (p. 14). An acute discussion of the subject is given by NAEGELI, Ueber die Bewegung kleinster Körperchen, in Untersuch. ü. niede re Pilze, 882. See also Sitzungsb. Münchener Akad., mathem.-phys. Klasse, 1879. 
9. (p. 14). LöFfler, Centralbl. f. Bakt. vi and vii. Since Löffler's classical work the cilia of bacteria have been the subject of numerous researches. Some details on general morphology and physiology are given in A. FISCHER's Untersuchungen über Bakt., Jahrb. f. wiss. Bot. xxvii, 1895.

10. (p. 15). This now generally adopted division was first given by MEsSEA, Rivista d'igiene e sanità publica, 1890,1 .

11. (p. 16). Observations of living bacteria during fission are given by BREFELD, Untersuchungen ü. Schimmelpilze, iv (B. subtilis). [See also MARSHALL WARD, I'roc. R. S., vol. lviii, 1895, p. 24, and Ann. Bot., vol. xiii, 1899, p. 227.] For determination of the rate of growth of the cholera vibrio by the plate method, see BUChNER, LONGARD, and RIEDLIN, Ueber die Vermehrungsgeschwindigkeit der Bakterien, Centralbl. f. Bakt. vol. ii.

12. (p. 19). The spores of bacteria had been already seen and described, but their properties and development were first accurately described by COHN, Untersuch. ü. Bakt. iv, in Beitr. z. Biol. d. Pflanzen, vol. ii, 1876. Germination of spores was seen by BrEFELD, note 11 . See also Prazmowski, Untersucl1ungen über d. Entwicklungsgeschichte u. Fermentwirkung einiger Bakterienarten, Leipzig 1880 ; also Biol. Centralbl. iv, 1884 (B. subtilis and $B$. anthracis). The newest observations (corroborating and extending former ones) on the conditions of sporulation are by ScHRelBer, Centralbl. f. Bakt., 1. Abt. vol. $\mathrm{xx}, \mathrm{I} 896$.

13. (p. 22). On the characters of arthrospores see DE BARr, Vergleichende Morphologie und Biologie der Pilze, Mycetozoen u. Bakterien, Leipzig 1884, pp. 496, 506.

14. (p. 24). For the question of species see BILLroth, Coccobacteria septica, Berlin I874; NAEgEl, Die niederen Pilze in ihren Beziehungen zu den Infektionskrankheiten und der Gesundheitspflege, Munich 1887; ZOPF, Zur Morphologie der Spaltpflanzen, Leipzig 1882. All these works favour pleomorphism. On the other side are COHN, Beitr. z. Biol. d. Pfl. i and ii; DE BARY, Vergl. Morphol. und Biol. d. Pilze, 1884, p. 511. These take the view that bacteria constitute good species and genera. See also HüPPE, Die Formen der Bakterien, Wiesbaden $\mathbf{I} 886$.

15. (p. 24). BüsGEx, Kulturversuche mit Clatothrix dichotoma, B. d. deutsch. bot. Ges. xii, 1894 .

16. (p. 26). Involution forms (after NAEGELI, note 14) are described in numerous works: BUCHNER in NAEgELi's Untersuchungen ü. niedere Pilze; also HüPPE, Formen d. Bakterien; PraZnowski, see note 12; Zopf, Die Spaltpilze, Breslau 1885 , 3rd ed. On the so-called branched tubercle-bacillus, Coppen Jones, Centralbl. f. Bakt. vol. xvii ; H. BRuns, ibid.; Diphtheria bacilli, BERNHEIM and FOLGER, ibid. vol. xx.

17. (p. 28). Pasteur, Chamberland, and Roux, De l'atténuation des virus et de leur retour à la virulence, Comptes rendus de l'Acad., Paris I881, vol. xcii ; also Chamberland, Le charbon et la vaccination charbonneuse, d'après des récents travaux de M. Pasteur, Paris 1883; Chamberland and Roux, Sur l'atténuation de la virulence de la bactéridie charbonneuse sous l'influence des antiseptiques. Comptes rendus, vol. xcvii, $188_{3}$.

18. (p. 28). On asporogenous anthrax and its properties: Roux, Bactéridie charbonneuse asporogène, Ann. de l'Inst. Pasteur, 1890 , vol. iv; PHISAlix in Comptes rendus, 1892, vol. cxiv. p. 684 , and vol. cxv. p. 253. 
19. (p. 30). A very good critical description, both morphological and physiological, of the known species of bacteria is given by LEHMANN and NEUMANN (note 3 ). The pathological forms are treated most fully, but the work may be strongly recommended to all students.

20. (p. 3o). Cohn's Sy'stematic Classification of the Bacteria in Beitr. z. Biol. d. Pfl. vol. ii.

21. (p. 32). Attempts at new systems introducing new genera have been recently published by A. Fischer (loc. cit., note 9), by Migula in Engler and Prantl's Die natürlichen Pflanzenfamilien, Lief. 129, and by LEHM.ANN and NEUMANN, loc. cit., note 3. The author offers the arrangement given in the text for further criticism and consideration.

22. (p. 39). For other pathogenic micro-organisms and fungi see FlïGGE (note 31 , where also figures and literature are given.

23. (p. 45). The methods and technique in the bacteriological analysis of air, water, earth, food-stuffs, \&c., will be found in the works cited in note 3 , and in every text-book of hygiene. The beginner will find a concrete exampic of method and results in: Hesse, Ueber quantitative Bestimmung der in der Luft enthaltenen Keime, Mitt. aus dem kaiserl. Gesundheitsamte, vol. ii, 1884; MIQUel, Des organismes vivant de l'atmosphère, Paris I883; Roux, Précis d'analyse microbiologique des eatx, Paris 1892 ; WOLFFHÜGEL, Erfahrungen ï. den Keimgehalt brauchbarer Trink- und Nutzwässer, Mitt. a. d. Reicbsgesundheitsamt, I886; LöFfLEk, Das Wasser u. die Mikro-organismen, Handbuch für Hygiene, vol. i, 2. Abt., 1896.

24. (p. 48 ). This mode of classification, as may be seen in these lectures, saves many' a long description.

25. (p. 50). A very readable description of the long conflict over the problem of spontaneous generation is given in LÖFFLER's lectures (note 4), and also fully in LAFAR's Technical Mycology; PASTEUR's classical work on the matter is Mémoires sur les corpuscules qui existent dans l'atmosphère: examen de la doctrine des générations spontanées, Annales de Chimie et Physique, I862, 3. série, vol. lxiv. It has appeared also in German (by WiELER) in OsTWaLD's Klassiker der exakten Wissenschaften, No. 39, Leipzig (Engehmann).

26. (p. 51). This rash statement has been made by Fermr, Centralbl. f. Bakt., 2. Abt. vol. ii, 1896.

27. (pp. 52, 53). NeNCKI und SCHEFFER, Ueber d. chemische Zusammensetzung der Fäulnissbakterien, Beiträge z. Biol. d. Spaltpilze, edited by NENCKI, Leipzig I 880 (reprint from the Journal f. prakt. Chemie, neue Folge, vols. xix and $\mathrm{xx}$ ); also KAPPES, Analysis of Mlass-cultures of the Thrush Fungus and some Bacteria, Leipzig I889; CRAMER, Die Zusammensetzung der Cholerabazillen, Archiv f. Hygiene xxii, 1895 .

28. (pp. 53, 56). NAEGELI, Ernährung der niederen Pilze durch Kohlenstofi- und Stickstoffverbindungen, Untersuchungen über niedere Pilze, 1882 (also in the Sitzungsber. d. math.-phys. Klasse d. Münchener Akad. der Wissensch. 1879). See also particularly BEYERINCK, Over lichtroedsel en plastisch voedsel van Lichtbakterien, Versl. en Mededel. der Amsterdamer Akad.d. Wissensch., Naturwiss. Abt., 2. Serie, vol. vii, 1890 ; here will be found also the division into pepton, amido, and ammonia bacteria ; FRÄNKEL, Beiträge z. Kenntniss des Bakterienwachstums auf eiweissfreien Nährböden, Hyg. Rundschau iv, 1894. The table on p. 55 is from personal experiments. 
29. (p. 57). Gelatine was introduced by ROBERT KOCH (Zur Untersuchung von pathogenen Mikroorganismen, Mitt. a. d. kaiserl. Gesund heitsamte, vol. i, I88I). Agar (prepared from red marine algae, Gracilaria, Eucheuma) was, according to HÜPPE (Methoden d. Bakterienforschung, 5th ed. p. 250), first used by FRAU HESSE.

30. (p. 58). LehMianN and Neumann (note 3).

31. (p. 6o). PASTEUR, Infusoires vivant sans gaz oxygène libre, Comptes rendus, vol. lii. pp. 344 and 1260, 1861. PASTeur, Études sur la bière, Paris 1876, chap. vi; NENCKI in the works given in note 27. The number of newer works on anaerobiosis is enormous, see notes $68,94,95,110$.

32. (p. 61). EngelmanN, Neue Methode zur Untersuchung der Sauerstoffausscheidung pflanzlicher und tierischer Organismen, Bot. Zeit. I881, and Ueber Sauerstoffausscheidung von Pflanzenzellen im Mikrospektrum, Bot. Zeit. I882.

33. (p. 63). F. CoHN, Ueber thermogene Bakterien, Berichte d. deutsch. bot. Gesellsch. xx. p. 66 (1893).

34. (p. 63). For phosphorescent bacteria see PFLÜger, Ueber die Phosphorescenz verwesender Organismen, Archiv f. d. gesamte Physiologie xi, I875 ; LuDwiG, Die bisherigen Untersuchungen über photogene Bakterien, Centralbl. f. Bakt. vol. ii, I 887 ; E. Fischer, Zeitschrift f. Hygiene, vols. i and ii, 1886, I887; BEYERINCK, note 28 , and in Archives Néerlandaises des sciences exactes et nat. vol. xxiii, I889; E. Fischer, Die Bakterien des Meeres, Plankton-Expedition, vol. iv, I894; KUTSCHER, Deutsche mediz. Wochenschrift, I 893.

35. (p. 64). From E. Fischer, Plankton-Exped. vol. iv, I 894.

36. (p. 65). Winogradsky, Ueber Schwefelbakterien, Bot. Zeit. I887; and in Beiträge z. Morphologie und Physiologie der Bakterien, Leipzig 1888.

37. (p. 68). Engelmann, Die Purpurbakterien und ihre Beziehungen zum Lichte, Bot. Zeit. I 888 ; see also previous note.

38. (p. 69). Winogradsky, Ueber Eisenbakterien, Bot. Zeit. I888; Molisch, Die Pflanze in ihren Beziehungen zum Eisen, Jena 1892, p. 60.

39. (p. 7I). A series of experiments on the influence of light on typhoid bacilli is given by JANOwSKI, Zur Biologie d. Typhusbazillen, Centralbl. f. Bakt. vol. viii, I890; also Buchner, ibid. vols. xi and xii. [See also Phil. Trans., I894, p. 961.]

40. (p. 72). According to Buchner (Centralbl. f. Bakt. vol. xi. p. 782) the influence of light on bacteria, such as typhoid, cholera, and putrefactive forms, is of decided importance in the self-purification of rivers. He even suggests white cemented clarifying or settling basins, in which sewage shall be exposed to sunlight before it is allowed to run into the rivers. In such cases, however, it would be necessary to prevent the organisms finding any shadowed spots; even the minute cracks in the cement would shield numbers of them from the sun.

41. (p. 72). For the effect of light on fungi see L. KLEIN, Ueber die Ursachen der ausschliesslich nächtlichen Sporenbildung bei Botrytis cinerea, Bot. Zeit. I885; also BREFELD, Bot. Untersuch. über Schimmelpilze, Heft 3, p. 87 (Coprinus), Heft 4, p. 76 (Pilobolus).

42. (p. 72). COHN and MENDELSOHN, Ueber die Einwirkung des elektrischen Stromes auf die Vermehrung der Bakterien, Beitr. z. Biol. iii, 1883.

43. (p. 72). Moller, references in Centralbl. f. Bakt., 2. Abt., vol. i. pp. 294 and 753 , and original in vol. iii, 1897 .

44. (pp. 72, 73). See VERwORN, Psycho-physiologische Protistenstudien, Jena 1889. 
45. (p. 73). Writuin, Centralbl. f. Bakt., 2. Abt. vol. ii, I 8,6, p. 676.

46. (p. 73). Certes, De l'action des hautes pressions sur les phénomines de la putréfaction et sur la vitalité des microorganismes d'eau douce et d'eau de mer. Comptes rendus, 1884 , vol. xcix. p. 385 (reference in Bot. Zeit. I885).

47. (pp. 73,75 ). The literature concerning bacteria in their relation to temperature is enormous, since almost every work dealing with a new species describes its behaviour to heat. The foundations of our knowledge of the subject were laid by CoHN (Untersuch. ü. Bakterien iv, in Beitr.z. Biol. vol. ii, i 876). He based his work on that of the older investigators in physiology and the problem of spontaneous generation, and showed first that the spores of the hay-bacillus resisted boiling. ROBERT KOCH introduced the methods and results of plant physiology into medical bacteriology, Beitr. z. Biol. vol. ii.

48. (p. 74). Miquel, P., Annuaires de l'observatoire de Montsouris I881, and Monographic d'un bacille vivant au delà de 70 centigrades (Bac. thermophilus), in Annales de Micrographie i, 1888 (references in Centralbl. f. Bakt. vol. v, I 889); also Globig, Zeitschrift für Hygiene, vol, iii, I888, and Rabinowitsch, ibid. vol. $\mathrm{xx}$.

49. (p. 75). For the lowest artificial temperatures and their effect upon organisms of all kinds, see WELTER, Die tiefen Temperaturen, ihre künstliche Erzeugung, etc., Krefeld I 895 .

50. (p. 77). Experiments innumerable have been made on the power of bacteria to resist desiccation; here again the fundamental facts were given by COHN in the Beitr. z. Biol. ; see also EIDAM, Die Einwirkung verschiedener Temperaturen und des Eintrocknens auf die Entwicklung von Bacterium termo, Beitr. z. Biol. vol. i, 1875 .

51. (p. 78). STAhl, Zur Biologie der Myxomyceten, Bot. Zeit. I884 (p. 165, Trophotropism).

52. (p. 78). PFEFFER, W., Lokomotorische Richtungsbewegungen durch chemische Reize, Untersuch. a. d. bot. Institut Tübingen, vol. i, I 884, and Ueber chemotaktische Bewegungen von Bakterien, Flagellaten und Volvocineen, ibid. vol. ii, I 888. In these two classical works will be found also a full discussion of Weber's law and Chemotaxis.

53. (p. 8o). For chemotaxis of leucocytes see: MASSART and BORDET, Recherches sur l'irritabilité des leucocytes, Société royale des sc. nat. de Bruxelles, 1890; GABRITSCHEwsky in the Annales de l'Inst. Pasteur, 1890 ; Buchner, Berl. klin. Wochenschr. I890; also the description given by RIEDER, Beiträge zur Kenntnis der Leukocytose, Leipzig 1892.

54. (pp. 81, 82, 83). On chemical disinfection abundant information will be found in medical literature; the subject is treated very fully by BEHRING, Bekämpfung der Infektionskrankheiten, I894. The fundamental principles were given by R. KOCH in Ueber Desinfektion, Mitt. aus dem kaiserl. Cesundheitsamte, vol. i, I88I; see also GEPpert, Die Wirkung des Sublimates auf Milzbrandsporen, Deutsche med. Woch. vol. xvii, I890; Yersin, De l'action de quelques antiseptiques et de la chaleur sur le bacille de la tuberculose, Annales de l'Inst. Pasteur, i 888 .

55. (pp. $83,85,86$ ). PAUL and KRönIG, Ueber das Verhalten der Bakterien zu chemischen Reagentien, Zeitschr. f. physik. Chemie, vol. xxi, I 896 , and Münchener mediz. Wochenschr. 1897 ; also Die chemischen Grundlagen der Lehre von der Gift- 
wirkung und Desinfektion, Zeitschr. f. Hygiene xxv, 1897. These works contain the first exact description of the relation between the poisonousness of a solution and its degree of dissociation.

56. (p. 85). For the new theories of dissociation see OsTwald, Grundriss der allgemeinen Chemie, and ed., and more fully in the same writer's Lehrbuch der allg. Chemie, and ed.

57. (p. 87). Review of a Russian work by KURLOFF and WAGNER, Ueber die Einwirkung des menschlichen Magensaftes auf krankheits-erregende Keime, Centralbl. f. Bakt. 1890, vol. vii; also HaMBURGER, Ueber d. Wirkung des Magensaftes auf pathogene Bakterien, Centralbl. f. klin. Medic. I880.

58. (p. 87). CADEAC and BOURNAY, Rô'e microbicide des sucs digestifs et contagion par les matières fécales (La province médicale, viii, 1893, referred to in Centralbl. f. Bakt. vol. xvi, 1894, p. 672).

59. (pp. $\& 9,91$ ). HEllriegel and Willfarth, Untersuchungen ïber die Stickstoffnahrung der Gramineen und Leguminosen, I888, Beilageheft zu der Zeitschr. d. Vereins f. d. Rübenzucker-Industrie des Deutschen Reiches.

60. (p. 89). For the anatomy and development of the root-nodules see: Woronin, Ueber die bei der Schwarzerle und der gewöhnlichen Lupine auftretenden IVurzelanschwellungen, Mém. de l'Acad. imp. Petersburg, 7. Serie, vol. x, I 866. BEYERINCK, Die Bakterien der Papilionaceenknöllchen, Bot. Zeit. I888, and Centralbl. f. Bakt. vol. xv, I894; B. Frank, Ueber die Pilzsymbiose der Leguminosen, Landwirtsch. Jahrb. I890; PRAZMOwSKI, Landwirtsch. Versuchsstation, 1890, vols. xxxvii and xxxviii. GonNERMann, Die Bakterien in den Wurzelknöllchen der Leguminosen, Landwirtsch. Jahrb. vol. xxiii, I 894. [See also DAwson, Phil. Trans., vol. cxcii, 1899, p. I, with references.]

61. (p. 92). BEYERINCK, Over ophooping van atmospherische stickstof in culturen von Bacillus radicicola, Akad. d. Wissensch., Amsterdam I $89 \mathrm{I}$; reviewed in Koch's Jahresber. vol. iii. p. 205, MAzÉ, Fixation de l'azote libre par le bacille des nodosités des Légumineuses, Annales Pasteur xi, 1897.

62. (p. 92). Nobbe, HiltNer, and Schuid, Versuche über die Biologie der Knöllchenbakterien der Leguminosen, insbesondere über die Frage der Arteinheit derselben, Landwirtsch. Versuchsst. vol.xlv, 1895. NoBBE and HILTNER, Ueber die Anpassungsfähigkeit der Knöllchenbakterien ungleichen Ursprungs an verschiedene Leguminosengattungen, ibid. vol. xlvii, 1 896 . In these papers will be found the experimental evidence for Nitragin.

63. (p. 95). If FRANK's assertion that there are no intercellular spaces in the bacteroidal tissue and that therefore free nitrogen cannot enter were true, then it would be equally impossible for oxygen to get into these parts of the rootnodules, which would be therefore anaerobic! A careful examination of any transverse section shows just the reverse, as might be expected.

64. (p. 96). Winogradsky, Sur l'assimilation de l'azote gazeux de l'atmosphère par les microbes, Comptes rendus der Pariser Akad. 1893, vol. cxvi. p. 1385; 1894, vol. cxviii. p. 353 ; and a collective Review in Archives des sciences biologiques, vol. iii, 1895, St. Petersburg (referred to in Bot. Zeit. 1895).

65. (p. 97). New light has been thrown on this matter by Kossowitsch, Untersuchungen über die Frage, ob die Algen freien Stickstoff assimilieren, Bot. Zeit. 1894. The experiments of Schloesing and Laurent (Ann. de l'Inst. Pasteur, 1892) are here critically discussed. 
66. (p. 99). WEHMl: l'ntersuchungen über die Füulnis der liüchte, in lieitrïgen zur Kenntnis einheimischer Pilze, 2. Heft, Jena 1895.

67. (p. 1co). SeLm in Sitzungsber. d. Akad. zu Bologna, 1872 and 1873 ; also Alcaloidi Cadarerici, Bologna 1881. BRIEGER, Ueber Ptomaine, Berlin 1885-86, Untersuchungen über Bakteriengifte in Berliner klinische Wochenschrift, 1890 , and many other essays. See also KOBERT, Lehrbuch der Intoxikationen, 1893.

68. (p. 100). Hopre-SEvler, Ueber die Einwirkung von Sauerstoff auf die Lebensthätigkeit niederer Organismen, Zeitschr. f. physiol. Chemie, I884, vol. viii. NExckI, Ueber den chemischen Mechanismus der Fäulnis, Journal f. prakt. Chemie, vol, xiii. IBrsstock, Ueber die Bakterien der Faeces, Zeitschr. f. klinische Medicin, vol. viii. HERFELD, Die Bakterien des Stalldüngers und ihre Wirkung, Centralbl. f. Bakt., 2. Abt. vol. i, 1895.

69. (p. 101). Wellyy, Die Zersetzung der organischen Stoffe und die Humusbildungen mit Riicksicht auf die Bodenkultur, Heidelberg i 897 .

70. (p. IOI). Morphology of putrefactive bacteria is treated especialiy by: CoHN. Beiträge z. Biol. vol. i, 1872 ; HAUSER, Ueber Fäulnisbakterien und deren Beziehungen zur Septikämie, Leipzig 1885; BIENSTOCK (note 68); KuHN, Morphol. Beiträge zur Leichenfäulnis, Archiv f. Hygiene, vol. xiii, 1891. Details as to saprogenic power (particularly the formation of indol) of pathogenic bacteria are given in many medical treatises : see the works of FL ̈̈GGE and LeHMANN and NEUMANN (note 3).

71. (p. I03). PASTeur and Joubert, Sur la fermentation de l'urine. Comptes rendus der Pariser Akad. I 876, vol. Ixxxiii. MIQUEL, P., Étude sur la fermentation ammoniacale et sur les ferments de l'urée. Annales de micrographie, r889-1893, rols. i-iii, v. In MIQUEL's works there are very fuli descriptions of the distribution, species, and functions of the numerous urine bacteria (good references in A. Koch's Jahresbericht, vols. i, ii, and iv).

72. (p. 104). The numerous papers of WARINGTON, MÜNTZ and others on nitrification have contributed much to our knowledge of the problem, but the key was first given by WINOGRADSKY, Recherches sur les organismes de la nitrification, $1^{\mathrm{e}}-5^{\mathrm{e}}$ mémoire, 1889-1891, Annales de l'Institut Pasteur iv, v, and Contributions ì la morphologie des organismes de la nitrification, Archives de sciences biol. publ. par l'Inst. impér. de méd. expér. à St. Pétersbourg, i, 1892: also Zur Mikrobiologie des Nitrifikationsprozesses, Centralbl. f. Bakt., 2. Abt. ii, r 896. Quite recently STUTZER and HARTLEB have published new observations on the saltpetre ferment (Centralbl. f. Bakt., 2. Abt. iii, r897). These observations may well lead astray those not familiar with mycology. The bacteria are said to grow out into a mycelium, and give rise to a whole host of different forms - a lapse back into the wildest traditions of p'eomorphism. STUTzER and HARTLEBS work is insufficient and full of faults, and is wanting entirely in reliable evidence. Such statements as theirs ought not to have appeared after BREFELD's work was once known. The real 'saltpetre bacteria' are and remain bacteria, and the reader may rely on their constancy.

73. (p. ro6). Conlewski, Ueber die Nitrifikation des Ammoniaks und die Kohlenstofiquellen bei der Emährung der nitrificierenden Fermente. (Polish.) Referred to in Centralbl. f. Bakt., 2. Abt. ii. p. 458.

74. (p. 106). BURRI and STUTzER, Ueber Nitrat zerstörende Bakterien und den durch dieselben bewirkten Stickstoffrerlust, Centralbl. f. Bakt., 2. Abt. i, 1 \&95. 
75. (p. I06). BEYERINCK, Ueber Spirillum desulfuricans als Ursache der Sulfatreduktion, Centralbl. f. Bakt., 2. Abt. i, 1895 .

76. (p. 108). V. Sommaruga, Ueber Stoffwechselprodukte von Mikroorganismen, iii. Zeitschr. f. Hygiene, vol. xviii, 1894 .

77. (p. 108). The newest collective treatise is LAFAR, Technical Mycology; Duclaux, Chimie biologique, Paris $\mathbf{I} 883$, is also to be recommended.

78. (p. I08). PASTEUR's pioneer work on the ferment organisms began with the investigation of spontaneous generation, and will be found in the works cited in note 25 and in many others. Of works on anaerobiosis (note 31) may be mentioned Mémoire sur la fermentation acétique (Annales de l'École normale supérieure, i, 1864); Mém. sur la fermentation appelée lactique (Annales de chimie et de physique, 3. série, vol. lii ; numerous investigations on the diseases of wine and beer in the Étude sur le vin, 1866, and Étude sur la bière, 1876. The first period of PASTEUR's brilliant life as an investigator was occupied with the physiology of fermentation, and laid the foundations of the latter half of his work, the study of pathogenic organisms.

79. (p. 108). Details and literature concerning enzymes and their rôle in the nutrition of plants and animals will be found in every text-book of physiology or physiological chemistry. [See also Green, 'The soluble Ferments and Fermentations,' Pitt Press, I899.] Theoretical considerations are given by E. Fischer, Ueber den Einfluss der Configuration auf die Wirkung der Enzyme, i-iii, Ber. deutsch. chem. Ges., vols. xxvii and xxviii, 1894 and 1895 .

S0. (p. I10). On the so-called Aspergillus yeast see Centralbl. f. Bakt., 2. Abt. i, Wehmer (pp. I 50, 565), Went and Prinsen Geerligs (p. 501) ; ii, Wehmer (p. 140).

81. (p. 110). Wehmer, Beitr. zur Kenntnis einheimischer Pilze, 1. Heft, I893.

82. (p. 112). HANSEN, Recherches sur les bactéries acétifiantes, Annales de Micrographie, 1894, also Travaux du laboratoire de Carlsberg, vol. iii (Meddelelser fra Carlsberg Laboratoriet, Kopenhagen). This work deals chiefly with the morphological sides of the question. The chemical changes had been already investigated by PASTEUR, and were known by experience.

83. (p. I13). From LAFAR, Physiologische Studien über Essiggärung und Schnellessigfabrikation, Centralbl. f. Bakt., 2. Abt. i, I 895 .

84. (p. 113). Review in Kосн's Jahresb. iii, 1892, pp. 230-32, of the work of Frankland and various collaborators.

85. (p. 115). PASTeur, Comptes rendus Pariser Akad. 1860, vol. li, p. 298 (racemic acid) ; LEwkowitch, Bericht deutsch. chem. Ges. vol. xvi (amygdalic acid) ; PÉRÉ, Sur la formation des acides lactiques isomériques par l'action des microbes sur les substances hydrocarbonées (Annales Pasteur, vol. vii, 1893).

86. (pp. II6, I17). PASTEuR, note 78 ; HüPPE, Untersuchungen über die Zersetzung der Milch durch Mikroorganismen, Mitteilung a. d. Reichsgesundheitsamt ii, 1884; ESCHERICH, Darmbakterien des Säuglings, Stuttgart I886; also KRAMER, Die Bakteriologie in ihren Beziehungen zur Landwirtschaft, 2. Teil, Wien 1892; DUClaux, Le lait, Paris 1887. Bacteria in cheese and milk, see v. FREUDENREICH, Ueber den Einfluss der beim Nachwärmen des Käses angewandten Temperatur auf die Bakterienzahl in der Milch und im Käse, Landwirtsch. Jahrb. d. Schweiz, vol. ix (referred to in Centralbl. f. Bakt., 2. Abt. vol. i, 1895). 
87. (p. II7). LAFAR, Die künstliche Säuerung des Hefegutes der Brennercien, Centralbl. f. Bakt., 2. Abt. ii, I $\$ 96$.

88. (p. 117). FLÜGGE, Die Aufgaben und Leistungen der Milchsterilisierung gegenüber den Darmkrankheiten der Säuglinge, Zeitschr. f. Hygiene, vol. xvii, I 894.

89. (p. 117). HeIs, Ueber das Verhalten der Krankheitserreger der Cholera, des Unterleibstyphus und der Tuberkulose in Milch, Butter, Molken und Käse, Mitteil. Reichsgesundheitsamt, I889; OBERMÜLler, Ueber Tuberkelbazillenbefunde in der Marktmilch, Hygienische Rundschau, 1895.

90. (p. I18). Conn, The relation of pure cultures to the acid, flavour, and aroma of butter, Centralbl. f. Bakt., 2. Abt. ii, I896; iii, I897.

91. (p. I18). Kramer, Duclaux, in note 86 ; also in Centralbl. f. Bakt., 2. Abt. vol. i, I895: v. FREUDENREICH, Bakteriol. Untersuchungen über den Reifungsprozess des Emmenthaler Käses; 1. c. vol. ii, 1896: v. KLECKI, Ueber den Reifungsprozess des Käses; Einen neuen Buttersäuregärungserreger (Bac. saccharobutyricus) und dessen Beziehungen zur Reifung und Lochung des Quargelkäses ; WeIZManN, Ueber den jetzigen Stand etc. des Käsereifungsprozesses; v. FREUDENREICH, Bemerkungen dazu.

91 a. (p. 120). v. FREUDENREICH, Bakteriol. Untersuchungen über den Kefir, Centralbl. f. Bakt., 2. Abt. iii, 1897. [For an account of the 'Ginger Beer Plant,' a similar association of a yeast and a bacterium, see MARshall WARD, Phil. Trans. I 892 , p. 125.$]$

92. (p. 120). See note 87 , and also LAFAR's Techn. Mycology. Numerous papers by EFFRONT are referred to in A. KOCH'S Jahresbericht; ROTHENBACH, Die Anwendung spaltpilzfeindlicher Agentien im Brennereibetriebe, mit besonderer Berücksichtigung der Kunsthefeführung, Zeitschr. f. Spiritusindustrie 1896.

93. (p. 120). Details in LafaR's Technical Mycology, vol. i. p. 259.

94. (p. 12I). Pasteur, note $3 \mathrm{I}$; van Tiegheni, Sur le Bacillus amylobacter, Bullet. soc. botan. xxiv. I 877, and Identité du Bacillus amylobact. et du vibrion butyrique de Pasteur, Comptes rendus, Paris 1879, vol. lxxxix ; PRAZMowski, note 12 ; GriMBERT, Fermentation anaérobique produite par le Bacillus orthobutylicus, ses variations sous certaines influences biologiques, Annales Pasteur vii. I 893 ; BEYERINCK, Ueber die Butylalkoholgärung u. das Butylferment, Verhandlungen der kgl. Akad. Amsterdam, 2. Sekt. i. I893, u. Centralbl. f. Bakt. 2. Abt. ii. p. 699; V. KLECK1, Ein neuer Buttersäuregärungserreger (Bac. saccharoliutyricus), ibid.; BAIER, Ueber Buttersäuregärung (a collective review), ibid. 2. Abt. i. 1895 .

95. (p. 122). VAN TIEGHEM, Sur le Bacillus amylotacter et son rôle dans la putréfaction de la cellulose, Comptes rendus, Paris, vol. lxxxviii. I879; HOPPESeyler, Zeitschr. f. physiol. Chemie, vol. $x$; OMeLIanski, Sur la fermentation de la cellulose, Comptes rendus 1895 .

96. (p. 123). P'ASTEUR, Étude sur le vin, 1866; van LAER, Note sur la fermentation visqueuse, Mémoires couronnés der belgischen Akad. Brüssel, vol. xliii. I889; KRAMER, Studien über die schleimige Gärung, Sitzungsber. Wiener Akad. d. Wiss. Natur-Cl. I889; LeIchmanN, Ueber eine schleimige Gärung der Milch, Landwirtsch. Versichsstat, vol. xliii. [See also MARSHALL WARD and GREEN, A Sugar Bacterium, Jroc. R. S., vol. lxv, p. 65, 1899.]

97. (p. 123). Winogradsky, Sur le rouissage du lin et son agent microbien. Comptes rendus, Paris 1895. 
98. (p. 124). Alvarkz, Sur un nouveau microbe, céterminant la fermentation indigotique et la production de l'indigo bleu. Comptes rendus, Paris I 887 , vol. cv.

99. (p. 124). BeHrens, Die Beziehungen der Mikroorganismen zum Tabakbau und zur Tabakfabrikation. Centralbl. f. Bakt. 2. Abt. ii. 1896.

100. (p. 124). VAn Tiegherr, Leliconostoc mesenteroides, Annales d. sc. nat., Botanique, 6. série, vol, vii. ; LIEsENBERG and ZOPF, Ueber den sog. Froschlaichpilz, Beitr. zur Physiol. u. Morphol. niederer Organismen, herausgegeben von Zopf, vol. i, I 892 ; Koch, A., and HosaEus, Ueber einen neuen Froschlaichpilz der Zuckerfabriken, Centralbl. f. Bakt. xvi. I894.

101. (p. 125). Lehmann, Ueber die Sauerteiggärung und die Beziehungen des Bac. levans zum Bac. coli, Centralbl. f. Bakt. xv. 1894; POPOFf, Sur un bacille anaérobique de la fermentation pannaire, Annales Pasteur 1890 ; Peters, Die Organismen des Sauerteiges und ihre Dedeutung für die Brotgärung, Bot. Zeit. I8\&9.

102. (p. 1:6). An interesting account of the history of alcoholic fermentation, which is largely identical with the history of the problem of spontancous generation, will be found in ADOLF MAYER's Lehrbuch der Gährungschemie, 3rd ed., Heidelberg 1879.

103. (p. 126). REESS, Botanische Untersuchungen über die Alkoholgährungspilze, I87o. The morphology, phy'siology, and technical employment of the yeasts have been furthered in an astonishing degree by the investigation of the Danish savant EMil Christian Hansen, published in the Meddelelser fra Carlsberg Laboratoriet in Kopenhagen i.-iii. $1878-94$, and in his Untersuchungen aus der Praxis der Cährungsindustrie, Heft i, 3rd ed. $1 \& 95$, Heft ii. I 892 . Hansen`s investigations (mostly on beer ycasts) have been taken up in the case of wine yeasts by WORTMANN (Untersuchungen über reine Hefen, Landwirtsch. Jahrb. 1 892, I \&94), by ADERHOLD, MÜLLER-THURGAU and others.

104. (p. 129). HANSEN, E. CH., Experimental studies on the variation of yeast-cells, Annals of Botany, ix. 1895.

105. (p. 129). A good icea of the importance of microbiology in technical processes is given by LINDNER, Mikrobiologische Betriebscontrolle in dem Gährungsgewerbe, Berlin 1895; of wine-making a popular account is given by WORTMANN, Anwendung und Wirkung reiner Hefen in der Weinbereitung; Eerlin 1895.

106. (p. I 30). BREFELD, Botanische Untersuchung über Hefepilze, v. I 883 (Ustilagineen); BRElELD, Landwirtsch. Jahrb., v. I876 (Mucorhefe); DE BARY, Veryleichende Morphologie und Biologie der Pize, I884, p. 286 (Exoascus and its relations to Saccharomyces); KLÖCKER and ScHIÖNING, Experiment. Unters. über die vermeintliche Umbildung verschiedener Schimmelpilze in Saccharomyces, Centralbl. f. Bakt. 2. Abt. ii. 1896, and Que savons-nous de l'origine des Saccharomyces? Meddelelser fra Carlsb. Labor. iv. 1896.

107. (p. I3I). For the enzymes and the power of fermentation of various yeasts and their sub-species (races) see E. FISCHER and LINDNER, Ueber Enzyme einiger Hefen, Wochenschr. f. Brauerei I895; also E. FISCHER in note 79 ; BEYERINCK, Ueber Nachweis und Verbreitung der Glukase, das Enzym der Maltose, Centralbl. f. Bakt. 2. Abt. 1895.

108. (p. I31). Claudon and Morin, Comptes rendus, Paris 1887 , referred to in the. Centralbl. f. Bakt. vol. ii.

109. (p. 132). Wortmann, Untersuchungen über den Einfluss des Lüftens sowie den 
der dauernden Gïrthïtigkeit auf den Charakter der Hefe, Weinbau u. Weinhandel, 1895, Nos. 25-27. [But see also A. Bkown, Fermentative Power, Centr. f. Bakt. u. Paras., 2. Abt., vol. iii. 1897.]

110. (p. 133). The most important works on the theory of fermentation are: TRAUBE, Theorie der Fermentwirkung, Berlin i 858 ; PASTEUR, Étude sur la bière, I 876, chap. vi.: Théorie physiologique de la Fermentation, first announced $186 \mathbf{I}$ (note 3I); NAEGELI, Theoric c'er Gährung, Munich I879. For intramolecular respiration see text-books of physiology. The metabolism theory, which is merely an expression of facts free from speculation, has not yet been carefully discussed nor considered in the light of the explanation afforded by other theories.

111. (p. 134). H. BUCHNER's statement (Die Bedeutung der aktiven löslichen Zellprodukte für den Chemismus der Zelle, Münch. mediz. Wochenschr. I897, No. 12) that an extract (pressure extract) of yeast free from cells can split up sugar into alcohol and $\mathrm{CO}_{2}$ is too incomplete to upset existing theories. Such a revolutionary statement ought to be supported by chemical analyscs, but these have not been given. In the two papers by ED. BUCHNER also (Alkoholische Gährung ohne Hefezellen) solid proofs of the existence and activity of the 'Zymase' (the alcohol-forming enzyme of the yeast cells) are wanting. In these papers there is a slight attempt at analytical evidence: the gas is calculated as $\mathrm{CO}_{2}$, and in two instances the alcohol was determined (Ber. d. deutsch. chem. Ges. I 897 , pp. II 7 and III0). Further communications of BUCHNER (Ber. d. deutsch. chem. Ges. 1897, p. 2668 ; 1898, pp. 200, 209, 568, I084, I53I) might seem to support his views more strongly against the objections raised, had not Abeles (ibid. I 898, p. 2335) recently shown that the amount of the poisons added to the extract was much too small in proportion to the amount of yeast frcm which the extract was obtained. The fragments of protoplasm in the extract would accordingly not all be killed, and might well give rise to the fermentative action of the extract, which would be quite inactive when sufficient amounts of poison are present. BLCHNER's observations have shown that the pressure-extract of yeast (free from uninjured cells) speedily sets up active fermentation in sugar solutions. But further researches are necessary to show whether a genuine Enzyme (BUCHNER'S 'Zymase') is the cause of the fermentation, or whether it is not rather due to the pressure-extract itself, which is indeed nothing more or less than a concentrated infusion of protoplasm squeezed out of the cells and preserved, as it were, in its own juice.

112. (pp. I03, I34). MiQuel, note 7I, and Sur le ferment soluble de l'urée, Comptes rendus, Paris $18 \mathrm{~g} o$, vol. iii. Urase decomposes at $50^{\circ}$ in from three to four hours, at $75^{\circ}$ in a few minutes, at $0^{\circ}$ it will keep in bouillon for weeks. The optimal temperature is said to be $50^{\circ}-55^{\circ}$. The urase formed in five days by Urobacillus Scliitzenlergii in one litre peptone bouillon converts at $37^{\circ}$ thirty-five grams of urea into carbonate of ammonia.

113. (p. 138). KokNauth, Ueber das Verhalten pathogener Bakterien im lebenden Pflanzengewebe, Centralbl. f. Bakt. xix. 1896; KASPARECK and KORNAUTH, Ueber die Infektionsfähigkeit der Pflanzen mit Milzbrandböden, Archiv f. d. gesamte Physiol, vol. lxiii. I 896.

114. (p. 138). FRANK and KRÜGER, Untersuchungen ïber den Schorf der Kartoffeln, Zeitschr. f. Spiritusindustrie I8g6; Rathay, Ueber das Auftreten von Gummi in der Rebe und über die 'Gommose baciilaire,' Jahresb. u. l'rogramm der k. k. önologischen u. pomologischen Lehranstalt K'losterneuburg, Wien I $\&$ ç; Margin, Sur la gonmose de la vigne, ard Sur la prétendiee 'Gommose 
bacillaire,' Revue de viticulture, 1895 (referred to in Centralbl. f. Bakt. 2. Abt. ii. 1896$)$.

115. (p. 138). Tischutkin, Die Rolle der Bakterien bei der Veränderung der Eiweissstoffe auf den Blättern von Pinguicula, Ber. d. deutsch. bot. Ges., vol. vii.; ScherfFel, Die Drüsen in den Höhlen der Rhizomschuppen von Lathraea Squamaria, Mitteilungen des bot. Instit. Graz, vol. i., and Bot. Zeit. 1890.

116. (p. I38). WATSON-CHEYNE and CHEShIRE, The pathogenic history under cultivation of a new bacillus (Bac. alvei), Journal of the Royal Micr. Society, London 1885 (foul-brood of bees); PASTEUR, Étude sur la maladie des vers à soie, Paris 1879 (Schlafsucht, Flacherie der Seidenraupen); SANarelt.I, Ueber einen neuen Mikroorganismus des Wassers \&.c., Centralbl. f. Bakt. ix. I 891 ; Ernst, Beiträge z. patholog. Anat. v. Ziegler, vol. viii. p. 203.

117. (p. 139). MENGE and KRÖNIG, Bakteriologie des weiblichen Genitalkanales, Leipzig $\mathbf{1} 897$.

118. (p. 139). Miller, Die Mikroorganismen der Mundhöhle. Die örtlichen und allgemeinen Erkrankungen, welche durch dieselben hervorgerufen werden. 2nd edit., Leipzig 1892. Muller, Einleitung zum Studium der BakterioPathologie der Zahnpulpa, Centralbl. f. Bakt. xvi. I894.

119. (p. I4I). GILBERT and Dominici, Recherches sur le nombre des microbes du tube digestif. (La semaine médicale, I 894, referred to in Baumgarten's Jahresber. $x$. p. 608.)

120. (p. 141). Escherich, Darmbakterien des Säuglings, Stuttgart I886; KIEssling, Das Bacterium coli commune, zusammenfassende Uebersicht, Hygienische Rundschau, I893; see also note 137 .

121. (p. I4I). NutTall and Thierfelder, Tierisches Leben ohne Bakterien im Verdauungskanal, i.-ii., Zeitschr. f. physiol. Chemie, xxi. and xxii.

122. (p. 142). SCHILD, Bakterien im Darminhalt Neugeborener, Zeitschr. f. Hygiene, vol. xix.

123. (p. 142). NEISSER, Ueber die Durchgängigkeit der Darmwand für Bakterien, Zeitschr. f. Hygiene, vol. xxii.

124. (p. I42). For the history of our knowledge of infectious diseases see LöfFLER, note 4. The question as to what is understood by the word 'infection' is discussed by BEHRING, Infektion und Desinfektion, Leipzig 1894 .

125. (p. 145). WATSON Cheyne, Report on a Study of the Conditions of Infection, British Medical Journal, I 886.

126. (p. I 47). Every text-book of the various branches of medicine gives a chapter to the bacteriology of that particular branch. It is therefore unnecessary to mention many works, but BAUMGarten's Pathologische Mykologie I890, and CORNIL and BABES, Les bactéries (3rd ed. 1893), may be named.

127. (p. 148). RosenBaCH, Mikroorganismen bei den Wundinfektionskrankheiten des Menschen, 1884 ; GARRÉ, Zur Aetiologie akut eitriger Entzündungen (Osteomyelitis, Furunkel und Panaritium), Fortschritte d. Med. I885; PASset, Untersuchungen über die Aetiologie der eitrigen Phlegmone des Menschen, Berlin 1885 ; LüBBERT, Biologische Spaltpilzuntersuchung, Würzburg 1886.

128. (p. 148). Rosenbach, see previous note; FEHLEISEn, Aetiologie des Erysipeles, Berlin 1883; PETRUsCHKY, Die verschiedenen Erscheinungsformen der Streptokokkeninfektion in ihren Beziehungen zu einander, Zeitschr. f. Hygiene, xviii. 1894. 
129. (p. I4S). NEISSER, A., Ueber den Pile der Gonorrhoe, Centralbl. f. d. ges. Med. I879; Buma, Die Mikroorganismen der gonorrhöischen Schleimhauterkrankung, Wiesbaden 1887; Wistuls, Die ascendirende Gonorrhoe beim Weibe, Bakteriologische und klinische Studien zur Biologie des Gonococcus ; NEISSER, Archiv f. Gynäkologie, vol. xlii. 1892; FINGER, GIION and SCHIAGENHAUFER, Beiträge zur Biologie des Gonococcus \&c., Archiv für Dermatologie, xxviii. I 894 .

130. (p. 149). FRĀNkeL, A., Bakteriologische Mitteilung, Zeitschr. f. klinische Med. x. I \$86, and Weitere Beiträge zur Lehre von der genuinen fibrinösen Pneumonie, ibid. xi. I886; Weichselbaus, A., Ueber dic Aetiologie der akuten Lungenund Rippenfellentzündungen, Wiener mediz. Jahrb. 1886.

131. (p. 149). КосH, RoBERT, Die Aetiologie der Milzbrandkrankheit, begründet auf die Entwicklungsgeschichte des Bacillus Anthracis, 1876. Beiträge z. Biol. der Pflanzen, vol.ii, and Mitteilungen aus dem Reichsgesundheitsamte, i. I 881 . The Anthrax rods were first observed in the blood by RAYER, Mémoires de la Société de Biologie, vol. ii., Paris 1851 ; POLLender, Mikroskopische u. chemische Untersuchung des Nilzbrandblutes, Caspers Vierteljahrsschr. f. gerichtl. Med. viii. I 855 ; BRAUELL, Versuche und Untersuchungen, betreffend den Milzbrand des Menschen u. der Tiere, Virchow's Archiv, vol. ix, 1857. The experimental proof that the rods were the actual cause of the disease was given (as far as was then possible without pure cultures) by DAVAINE, who inoculated animals with blood containing the bacilli: sce Recherches sur les infusoires du sang dans la maladie connue sous le nom de sang de rate, Comptes rendus, vol. Ivii. I 863 , vol. lix. I 864 , \&c. See also notes 17 and 18.

132. (p. I 50 ). Nicolaier, Beiträge zur Aetiologie des IVundstarrkrampfes, Dissert. Göttingen 1885 (also in the Deutsche mediz. Wochenschr. 1884); KitasATo, Ucber den Tetanusbacillus, Zcitschr. f. Hygiene vii. I889; KITT, Ueber Tetanusimpfungen bei Haustieren, Centralbl. f. Bakt. vol. vii. 1890.

133. (p. 150). LÖFFLER, Untersuchungen übcr die Bedeutung der Mikroorganismen für die Entstehung der Diphtheric, Mitteilungen aus d. Reichsgesundheitsamte, vol.ii. 1884; Roux and Yersin, Contribution à l'étude de la diphthérie, Annales Pasteur, ii., iii., iv., 1888 to 1890 ; Escherich, Aetiologie u. Pathogenese der epidemischen Diphtherie, Wien 1894.

134. (pp. I 52, I68). KоCH, R., Die Aetiologie der Tuberkulose, Mitteilungen a. d. kaiserl. Gesundheitsamte, ii. I 884 ; NOCARD and Roux, Sur la culture du bacille de la tuberculose, Annales Pasteur, i. I887; Proskauer and Beck, Beiträge zur Ernảhrungsphysiologie des Tuberkelbacillus, Zeitschr. f. Hygiene, xviii. I894; CZAPLEwSKI, Dic Untersuchung des Auswurfes auf Tuberkelbazillen, Jena I891; also note 16 .

13.5. (p. 152). GÄRTNER, Ueber dic Erblichkeit der Tuberkulose, Zeitschr. f. Hygiene xiii. 1893 .

136. (p. 153). According to R. Koch's latest publication (Ueber neue Tuberkulinpräparate, reprinted from the Deutsch. med. Wochenschr. 1897) the stronger tingibility of the tubercle bacillus is due to the presence of two fatty acids. After their removal by hot caustic soda solution, the tubercle bacilli are said to stain.just as other bacteria do. In the opinion of the author this agrees perfectly with the physical theory of staining (p. 7, see $A$. FISCHER, Untersuchungen über den Bau der Cyanophyceen und Bakterien, 1\$97!. For hot caustic soda undoubtedly lessens the density of the cell contents and membrane, and so reduces the power of storing up the colour. This is the explanation of 
KocH's observation, not the solubility of the fatty acids, which are doubtless quite inactive.

137. (p. I54). GAFFKY, Zur Aetiologie des Abdominaltyphus, Mitteil. aus dem Reichsgesundheitsamt, ii. I884; ESCHERICH and KIESSLING, note I20; EHRENFEST, Studien über die 'Bactcrium coli ähnlichen' Mikroorganismen normaler menschlicher Fäces, Archiv f. Hygiene xxvi. I896; LöFFLER and ABEL, Ueber die spezifischen Eigenschaften der Schutzkörper im Blute Typhus- und Coliimmuner Tiere, Centralbl. f. Bakt. vol. xix. 1896.

138. (p. I55). LÖFFLER, Ueber Epidemieen unter den im hygienischen Institute zu Greifswald gehaltenen Mäusen und über die Bekämpfung der Feldmäuseplage, Centralbl. f. Bakt. xi. I\$92 ; KoRNauth, Die Bekämpfung der Mäuseplage mittels des Bacillus typhi murium, ibid. xvi. 1894. Gives the results of thirty-six farmers, of whom thirty were successful, some highly so.

139. (p. 1 55). KoCH, R., in Bericht über die Thätigkeit der zur Erforschung der Cholera im J. 1883 nach Egypten und Indien entsandten Kommission, Berlin I 887 , bei Springer. VOGES, Die Cholera-Immunität, zusammenfassende Uebersicht, Centralbl. f. Bakt. xix. I 896.

140. (p. 155). Pettenkofer, M. V., Ueber Cholera, mit Berücksichtigung der jüngsten Choleraepidemie in Hamburg. Münchener mediz. Wochenschrift, xxxix. 1892.

141. (p. 156). On cholera-like vibrios, e.g. FINKLER and PRIOR, Forschungen über Cholerabakterien, Bonn I884. Gamaleïa, Vibrio Metschnikovi et ses rapports avec le nicrobe du choléra asiatique, Annales Pasteur, ii. I888. HeIDER, Vibrio danubicus, Centralbl. f. Bakt., xiv. I893. GüNTHER, Vibrio aquatilis, Deutsche mediz. Wochenschr. I892. DIEUdonNE, Zusammenfassende Uebersicht über die in den letzten zwei Jahren gefundenen 'choleraähnlichen' Vibrionen, Centralbl. f. Bakt. xvi. I 894.

142. (pp. I 59, I62). Experiments for obtaining the diphtheria toxines are described by' RouX and Yersin, Annales Pasteur, ii.-iv. I $888-90$. Löffler, Der gegenwärtige Stand der Frage nach der Entstehung der Diphtherie, Deutsche mediz. Wochenschr. I 890 . BRIEGER and C. FRÄNKEL, Untersuchungen über Bakteriengifte, Berliner klinische Wochenschr. 1890. DzıERGowski and REkowSKI, Recherches sur la transformation des milieux nutritifs par les bacilles de la diphthérie et sur la composition chimique de ces microbes, Archives d. scienc. biol. publ. par l'Inst. imp. de méd. expérim. Pétersbourg, vol. i. 1892. Kossel, Zur Kenntnis des Diphtheriegiftes, Centralbl. f. Bakt., xix. I 896.-On tetanus poison: Kitasato, Experimentelle Untersuchungen über das Tetanusgift, Zeitschr. f. Hygiene, x. I 890 . GUMPRECHT, Versuche ïber die physiologische Wirkung des Tetanusgiftes im Organismus, Archiv f. die ges. Physiol, vol. lix. I 894. BRIEGER and COHs, Untersuchungen über das Tetanusgift, Zeitschr. f. Hygiene, xv. 1893. BRIEGER and BOER, Deutsche mediz. Wochenschr. I 896 , No. 49.-See also notes $143,145,147,152$. At the present time vigorous efforts are being made to isolate the toxines of all the pathogenic bacteria.

143. (p. I60). КосH, R., Weitere Mitteilungen über ein Heilmittel gegen Tuberku'ose, Deutsche mediz. Wochenschr. I890, No. $46^{\text {a }}$, I891, No. 3 ; KüHNE, Zeitschr. f. Biologie, Neue Folge, vol. xi. I 893 (Chemische Untersuchung des Tuberkulins von I 890$)$; КосH, R., Ueber neue Tuberkulinpräparate, Deutsche mediz. Wochenschr. 1897 , No. 14.

144. (p. 161). VAx TiegheM, Sur le ferment butyrique à l'époque de la houille (Carboniferous period), Comptes rendus, Paris I $8 \delta 0$, vol. xcix., and Annales 
d. scienc. nat., liotan., 6. série, ix. ISSo; abo RLNAtLT, Recherches sur les bactériacées fossiles, ibid. 8 . série, ii. 1896.

145. (p. I61). Metschnikorf, Ueber die Beziehungen der I'hagocyten zu Milzbrandbazillen, Virchow's Archiv, xcrii. 1884, Théorie des Phargocytes, Annales Pasteur, i. 1887 , and numberless other papers by METSCHNIKOFF that are largely devoted to the polemical war that arose over his doctrines, such as: FlüsGE, Studien über die Abschwächung virulenter Bakterien und die erworbene Immunität; HITTER, Kritische Bemerkungen zu Metschnikoff's I'hagocytenlehre; NUT'IALL, Experimente über den bakterienfeindlichen Einfluss des tierischen Körpers, Zeitschrift f. Hygiene, iv. 1888 ; BAUMGAR'Ten, Ueber das 'Experimentum crucis' der Phagocytenlehre, Ziegler's Beiträge zur pathol. Anat., vii. I 889 -METSCnNıkoFf, Immunität, in Weyl's Handb. d. Hygiene, vol. ix., I. Lief. I 897 .

14\%. (p. 162). IUUCHNER, Ueber die bakterientötende Wirkung des zellenfreien Blutserums, Centralbl. f. Bakt. v. and vi. I889; Ueber die nähere Natur der bakterientötenden Substanz im Blutserum, ibid. vi.; Untersuchungen über die bakterienfeindlichen Wirkungen des Blutes und Blutscrums, Archiv f. Hygiene, x. pp. $84-173$, I 890 . FODOR, Neue Untersuchungen über dic bakterientötende Wirkung des Blutes und über Immunisation, Centralbl. f. Bakt. vii. I Sgo. See also notes 154 to $16 \mathrm{I}$ on the specific serum reactions.

147. (p. I63). BORDET, Sur le mode d'action des sérums préventifs, Annales Pasteur, $1896, x$; Les leucocytes et les propriétés actives du sćrum chez les vaccinés, ibid. ix. I 895. Roux, Sur les sérums antitoxiques, ibid. 1894, viii. HAHN, Ueber dic Bezichungen der Lcukocyten zur baktericiden Wirkung des Blutes, Archiv f. Hygiene, xxv. 1895 .

148. (p. 163). KOBERT, Lehrbuch der Intoxikationen, 1893, pp. 261, 554 ; EHRLich, P., Experimentelle Untersuchungen über Immunität, Deutsche mediz. Wochenschr. I 891 , Nos. 32 and 44 (experiments with ricin and with abrin, the poisonous principle in the seeds of Abrus precatorius).

149. (p. 163). BEHRING, Infektion und Desinfektion, I $\$ 94$, p. I72, \&c., and many other papers; see also the subsequent notes. EHRLICH, KosSEL, and WASSERMANN, Ueber Gewinnung und Verwendung des Diphtherieheilserums, Deutsche mediz. Wochenschr. 1894, No. 16; Ehrlich and Wassermann, Zeitschr. f. Hygiene, xviii. 1894.

150. (p. 164). BEHRING, Die Blutserumtherapie. i. Die praktischen Ziele und dic Immunisicrungsmethoden zum Zweck der Gcwinnung von Heilserum; ii. Das Tetanusheilserum und seine Anwendung auf tetanuskranke Menschen. Leipzig, 1892 .

151. (p. 164). Roux and MarTin, Contribution à l'étude de la diphthéric, Annales Pasteur, viii. I 894 .

152. (p. 164). In BEHRING, Bekämpfung der Infektionskrankheiten, Infektion und Desinfektion, 1894, p. 188, and in many other passages, the specific antitoxic effect of the serum is emphasized. It has no anti-bacterial (bactericidal) action.

153. (pp. 161, 165). Ehrlich and Wassermann, Ueber dic Gewinnung der Diphtherieantitoxine aus Blutserum und Milch immunisierter Tiere, Zeitschr. f. Hygiene, xviii. I 894 .

154. (p. 165). EHRIICI and HÜBENER, Ueber die Vererbung der Immunität bei Tetanus, Zeitschr. für Hygiene, xviii. 1894. VAILlard, Sur l'hérédité de l'immunité acquise, Annales l'asteur, x. I 895. 
155. (p. I65). BEHRiNG, Infektion und Desinfektion, p. 160, and Deutsche mediz. Wochenschr. 1893, No. 48. IVLADIMIROFF, Ueber die antitoxinerzeugende und immunisierende IVirkung des Tetanusgiftes, Zeitschr. f. Hygiene, xv. I 893.

155. (p. 165). If this assumption were correct it would explain the well-known fact that only the earliest stages of diphtheria can be successfully treated by the serum method. It would account too for Koch's observation (note 143) that the new tuberculin T. R. must be used within one or two weeks of inoculation if it is to have a really curative effect. In all these cases the toxines introduced artificially may be imagined to bring about toleration before the body is inundated with poison from the bacterial centres.

157. (p. I66). Roux, Sur les sérums antitoxiques (Ann. Pasteur I894), thinks it probable that the antitoxines act upon the tissue cells and make them insensitive to the toxines. BEHRING (Infektion und Desinfektion) is inclined to think the toxines are destroyed by the antitoxines.

158. (p. 166). BEHRING in the works cited; also in Die Geschichte der Diphtherie, Leipzig 1893, and Gesammelte Abhandlungen zur ätiologischen Therapie, Leipzig 1893. EHRLICH, Die staatliche Kontrolle des Diphtherieheilserums, Berl. klin. Wochenschr. I 896.

159. (p. 166). Of the innumerable works on the value of serum therapeutics that have already appeared may be mentioned: BEHRING, Die Statistik der Heilserumfrage, Marburg I 895 ; HeubNer, Klinische Studien über die Behandlung der Diphtherie mit dem Behring'schen Heilserum, Leipzig 1895; EsCHERICH, Diphtherie, Croup und Serumtherapie, I895; GotTsteIN and Schleich, Immunität, Infektionstheorie und Diphtherieserum, Berlin I 894 ; GANGHOFNER, Die Serumbehandlung der Diphtherie, Jena I 897.

160. (p. I66). Pfeiffer, Die Differentialdiagnose der Vibrionen der Cholera asiatica mit Hilfe der Immunisierung, Zeitschr. f. Hygiene, xix. I895; Pfelffer, Centralbl. f. Bakt., xix. 1896, pp. 191, 385, 593 ; ibid. xx. I896, p. I 29. BORDET, Sur le mode d'action des sérums préventifs, Annales Pasteur, I 896. DUnBaR, Zur Differentialdiagnose der Choleravibrionen, Zeitschr. f. Hygiene, vol. xxi.

161. (p. 167). PfEIfFer and Proskauer, Beiträge zur Kenntnis der spezifisch wirksamen Körper in Blutserum von choleraimmunen Tieren, Centralbl. f. Bakt., xix. 1896, p. 197.

162. (p. I68). PASTEUR, Comptes rendus, Oct. 26, 1885, and in many other papers on this very remarkable inoculation, which is indeed a kind of serum treatment. For the organs employed (cord and brain) contain not only the postulated antitoxin, but also the poison which is thus introduced into the bitten animals, only by a different vehicle. Pasteur's genius did not need pure cultures of the unknown hydrophobia germ, and this gives us a right to hope that we may succeed with his method in the case of other diseases.

163. (p. 168). CHAMBERLAND, Résultats pratiques des vaccinations contre le charbon et le rouget en France, Annales Pasteur, viii. I 894 ; see also note 17.

164. (p. 168). GRUBER, Münchener mediz. Wochenschr. 1896, applies the term 'glabrificines' to the substances in the blood of immunized animals, which cause the membranes of the bacteria to swell up, and the rods themselves to agglutinate. 'Lysines' and 'antilysines' were introduced by KRUSSE (FLÜGGE, Mikroorg., 3rd ed., vol. i. pp. 409, 4I4). Of all these substances we know only the names. 


\section{N D E X}

Abeles, criticism of Buchner, p. 179.

Acetic acid, 100; production of by anthrax bacilli in milk, 118 , by bacteria, 113 , I 14 ; by butyric - I 21 ; in fermentation of bread, 125; by kephir, I20; by yeast, I 32 .

Acetic bacteria, I I I, Fig. 24; literature of, 176 ; cessation of growth of in partial vacuum, $6 \mathbf{I}$.

Acetic fermentation, 112 ; activity of, 113 ; equation for, II2.

Achorion Schoenbeinii, occurrence of in Favus, 42 .

Acne, cause of, 148.

Actinomyces, suppuration induced by, 148 ; $A$. bovis, culture and characters of, $4 \mathrm{I}$; supposed sporangia of, 42 .

Aerobes, definition of, 60 .

Aetherial oils as disinfectants, 86 .

Agar media, 57; non-liquefaction of by bacteria, 59.

Air, presence of bacteria in, 44 .

Albumoses, properties of, 99.

Alcohol, heat of combustion of, 135 ; inhibitory percentage of, $83 ;-$ for acetic bacteria, II 2 ; lethal percentage of, 83 ; resistance of spores to, 84 ; negative chemotaxis of, 79 .

Alcoholic fermentation, 126 seq., I78, I31 ; by-products of, 132 ; influence of oxygen and temperature on, 132 .

Alcohols, nutritive value of, 57 ; fermentation of, I I 4 .

Aldehydes, production of by yeast, 132 .

Alder, root-tubercles of, 89.

Alexines, occurrence and importance of, 162.

Alimentary canal, bacteria of, 180 .

Alkalies, influence of on toxines, 160 ; negative chemotaxis of, 79 .

Allococcaceae, characters of, 32,33 .

Alvarez, on indigo fermentation, 178 .

Amido-bacteria, 55 ; - compounds, 99.

Amines, nutritive value of, 57 .
Ammonia, occurrence of in cheese, 119 ; production of by putrefaction and fermentation, I03.

Ammonia-bacteria, 55 .

Ammonium chloride, as source of nitrogen, 55 ; - tartrate as source of N, 55

Amoebil, importance of, 39 ; rapidity of fission in, I $8 ; A$. coli, connexion of with dysentery, 40 .

Amygdalic acid, bacterial decomposition of into + and - optical components, 115.

Amyl alcohol, production of by yeast, 132 .

Amylobacter butyricus of van Tieghem, $12 \mathrm{I}$.

Anaerobes, definition of, 60 .

Anaerobic bacteria, distribution and importance of, 61 ; - fermentation, reduction of indigo during, 133 .

Anaerobiosis, literature of, 172,176 ; relation of to fermentation, 133,135 .

Anilin dyes, as disinfectants, 86 .

Animalcula, definition of, $\mathbf{I}$.

Anthrax bacilli, abscesses due to, 145 ; asporogenous varieties of, 170 ; facultative parasitism of, 49 ; formation of chains by, 3 ; germs of, 149; growth of in fluid media, 58 ; in milk, I 17, II 8 ; history of, 149; infection by, 145; inoculation for, 168 ; literature of, 181 ; transference of, I $50 ;-$, inhibitory per cent. of poisons for, 82 ; - lethal per cent. for spores of, 83 ; permanence of, 30 ; plate and stab-cultures of, 59 ; resistance of to low temperatures, 75 ; size of, $4 ;-$ spores, vitality of, 77 .

Antilysines, 168, 184 .

Antiseptics, 173; - treatment of wounds, 87.

Antitoxins, hypothetical character of, 166: literature of, 183,$184 ;$ occurrence and properties of, 162,163 ; theory of, 165 . Aphanothece, shape of, 37 .

Arsenious acid, influence of on ferments, I09. 
Arthrospores, 22, 23.

Aseptic treatment of wounds, $S_{7}$.

Ash, percentage of in bacteria, 52 ; essential amounts of, 53,54 .

Asparagin, as source of nitrogen, 55 ; chemotactic attraction of, 79 .

Aspartic acid, 99.

Aspergillus, parasitism of, 42; pathogenicity of species of, 42 ; - yeast, I IO, I76.

Asporogenous condition, induction of, 28 .

Attenuation, 27; influence of on spore formation and virulence, 28.

Australia, nitrite bacteria of, I05.

Autoclave, use of, 76 .

liacilleae, 33 .

Bacallus, I ; definition of, 2, 32 ; characters of genus, 33; B. acti, III, Fig. 24, action of I on, I I $3 ; B$. acidi lactici, III, Fig. 24, shape and properties of, I 7 ; 13 . acidificans longissimus, shape of, $117 ; \mathrm{B}$. aerogenes, shape of, 117 ; B. anthracis, capsules of, 10, Fig. 7 ; characters and life-history of, I49; formation of spores of, 20, Fig. II ; conditions for - , 23, 150; germination of, 20, Fig. 11, 22; growth of in culture media, 55; plugging of capillaries by, $159 ;$ production of caprionic acid in milk by, 118 ; temperature optimum for, 28 , minimum and maximum for, 74 ; b.brunneus, colour of, $12 ; B$. buccalis maximus, p. I, Fig. I; granulose reaction of, I39; shape of, 140, Fig. 26; occurrence of in faeces, I4I;B. Chaureil, I 50, pathogenic character of, $112 ; \mathrm{l}$. coli, IOI, I 51, Fig. 28; growth of on different culture media, 55; - influence of acidity of on, 56 ; non-liquefaction of gelatine by, 5S: production of indol by, I02; $b$. coli communis, I 5 ; fermentative properties of, 112 ; fermentation of carbohydrates by, IO2; influence of peptone and ammonia on fermentative products of, II5; $B$. cyanco-fuscus, pigment of, $13 ;$ B.cyanogenus, colour of, 12 ; discolouration of milk by, II $8 ; B$. diphtheriae, I5I, Fig. 28; characters of, 150, I51, Fig. $28 ; B$. ethaceticus, fermentative activity of, $114 ; B$. fluorescens liquefaciens, chemotactic attraction of, 79, Fig. I8; putrefactive properties of, I02; $B$. indigogenus, fermentation of indican by, I24; B. Kiutzingianus, I I I, Fig. 24 ; action of I on, II $; B$. leptosporus, germination of spore of, 20 , Fig. II, 22; B. maligni oedematis, I $50 ; B$. orthobutylicus, fermentative activity of, 114 ; properties of, 121 ;
B. P'asteuriunus, 111, Fig. 24; action of 1 on, II2; fermentative activity of, I13; $B$. phosphorescens, minimum, maximum, and optimum temperatures for, $74 ; B$. prodigiosus, colour of, 12 ; coloration of milk by, 118 ; percentage composition of, 52 ; production of lactic acid by, II6; B. proteus, 15 , 102, Fig. 22; $B$. putrificus coli, occurrence of in intestine, I4I ; putrefactive products of, $102 ; B$. pyocyancus, decomposition of fat by, IO\&; growth of on culture media, 55 ; in sugar solution, 56 ; suppuration due to, 148 ; $B$. raticicola of Beyerinck, $92 ; B$. subtilis, I5, Fig. 8 ; cessation of growth of in partial vacuum, 6I ; ciliation of, I5; permanence of,$- 31 ;$ supposed conversion of anthrax bacilli into, 30 ; germination of spore of, 20 , Fig. II, 22 ; growth of on culture media, 55 ; influence of acidity of on, 56 ; involution forms of, 26, 27, Fig. I4; life cycle of, 25, 26, Fig. 13; minimum, optimum, and maximum temperatures for, 74 ; rapility of fission in, 17 ; resistance of spores of to boiling, 76 ; B. tetumi, 151, Fig. 28 ; characters of, I 50 ; obligate anaerobiosis of, 6I ; b. thermophilus, optimum, minimum, and maximum temperatures for, 74 ; 1). tuberculosis, 151, Fig. 28 ; absence of spores in, 153; characters of, 153 ; culture of, 152 ; cellulose in cell-wall of, 9 ; growth of in fluid media, 58; minimum, maximum, and optimum temperatures for, 74 ; tingibility of, I 81 ; B. typhi, 15 I, Fig. 28 ; characters of, I 54 ; ciliation of, I5; growth of in culture media, 55 ; non-liquefaction of gelatine by, 58; polar granules of, 9; B. typhi murium, use of, 154 ; B. ureae, 102, Fig. 22 ; . riolaceus, arthrospores of, 23 ; colour of, 12 ; distribution of pigment in, 13 ; influence of oxygen on pigment formation of, 61 ; B. virens, distribution of pigment in, $12 ; B$. wiscosus sacchari, nutrition of, $123 ; B$. vulgaris, nutritive requirements of, 29; putrefactive powers of, IO2 ; zoogloea of, 31 .

Bacteria, of mouth and teeth, I40, Fig. 26; diseases of plants induced by, 138 ; non-penetration of plants by, 138 .

Bactericidal substances, 83 , I66.

Bacteriological analysis, methods and technics of, I7I ; of soils, 47.

Bacterio-purpurin, functions and spectrum of, 68, 69.

Bacteriosis, 138 .

Bactcrium, definition of, 32 ; dimensions of, $4 ; B$. aceticum, $110 ; B$. acidi 
lactici, definition of, 116 ; li. busyricum, 110; b.coli commun:, occurrence and properties of, I4I, 142; $l$ ? P'asteurianum, involution forms of, 27, Fig. 14 ; 13. photometricum, photop.ailism of, 72 ; B. ranicidum, pathogenic character of, $38 ; \mathrm{b}$. termo, definition of, 101; h. Zopfi, 102, Fig. 22.

bacteroids, as involution forms, 27 ; shape of, 90 , Fig. 19.

Batridium, characters of genus, $33 ; B$. coli, 151, Fig. $28 ; B$. coli commune, I 54 ; L. proteus, 102, Fig. 22 ; colony of, $4 ; b . t y p h i$, I 5 I, Fig. 28.

bictrillum, characters of genus, $33 ; \mathrm{B}$. pseudotermo, 102, Fig. 22.

Bactrinium, characters of genus of, 33 .

Baier, on butyric fermentation, 177 .

liaktron, 32.

liarium, substitution of for calcium, 54 .

Baumgarten, on phagocytosis, 183 ; on pathological mycology, I 80.

Beer, mucilaginous 'fermentation' of, 123 ; spoiling of, 120 ; - yeast, purification of, 120 .

liees, bacterial disease of, 138 .

Begriatoa, 65, Fig. 17, 66; characters of, 2, 34 ; oscillating movements of, 16.

liehrens, on tobacco fermentation, 178 .

lehring, on antitoxic serum, 184 ; on disinfection, 173, 184; on immunization of horses to tetanus, 164 ; on infection, 100 ; on serum therapeutics, 183.

Behring and Ehrlich, on antitoxins, 166.

Benzoic acid, nutritive value of, 57 .

Bernheim and Folger, on involution forms of diphtheria bacilli, 170 .

Beyerinck, on artificial culture of roottubercle bacteria, 92 ; on assimilation of nitrogen by Bacillus radicicola, 174 ; on butyric bacteria, 121 ; on butyric fermentation, 177 ; on glucose, 178 ; on nutrition of bacteria, 56, 171; on pigment bacteria, 169 ; on phosphorescent bacteria, I72; on root-tubercle bacteria, 174; on Spirillum desulfuricans, 176 .

Bienstock, on faecal bacteria, 175 .

Bile, action of on bacteria, 87 .

Billroth, on bacteria of wounds, 28 ; on species of bacteria, 170.

biochemistry, Chap. X-XIV.

13itter, on phagocytosis, 183.

Blastomycetes, 126.

Blood, occurrence of bacteria in, 142; pathogenic bacteria of, 145 .

Blood-serum, as nutritive medium, 57 .

Bordet, on preventive serums, 183,184 .

Botrytis cinerea, inhibitory action of light on spore formation in, 72 ; rotting of fruits due to, 99.
Bouquet of wine, origin of, 129.

Branching, of filamentous bacteria, 3.

Branell, on anthrax, $\delta \mathrm{I}$.

Bread, cause of rising of, 125.

Brefeld, on division of bacteria, 170; on fungal yeasts, 178 ; on grermination of bacterial spores, 170 ; influence of light on fungi, 172 .

Brieger, on ptomaines, 100, 175 ; I3., Boer and Cohn, on tetanus poisons, I 82 : 13. and Fränkel, on bacterial poisons, 182.

Bromine water, lethal percentage of, 83 , 84.

Brown, on fermentative power, 179.

Brownian movement, 14.

Bruns, on tubercle bacillus, 170 .

Buchner, on alexines, 162 ; on bactericidal action of blood serum, 183 ; on chemotaxis of leucocytes, 173 ; influence of light on bacteria, 172 ; Ed. Buchner on zymase, $179 ; \mathrm{H}$. Buchner, on alcoholic fermentation without yeast cells, 179 .

Buchner, Langard, and Riedlin, on rapidity of multiplication of bacteria, 170.

Budding, rapidity of in yeast cells, 126.

Bumm, on micro-organisms of gonorrhoea, I 81 .

Burri and Stutzer, on denitrifying bacteria, 175 .

Büsgen, on culture of Cladothrix dichotoma, 170.

Bütschli, on Cyanophyceae and Bacteria, I69.

Butter, number of bacteria in, I 8 ; causes of rancidity and of flavour of, i 18 .

Butyl-alcohol, production of by bacteria, $114,122$.

Butyric acid, 100 ; heat of combustion of, 135 ; occurrence of in cheese, 119 ; production of by bacteria, $114 ;$ - in rancid butter, i 8 .

Iutyric bacteria, fermentation of lactic acid and of milk by, 122; spoiling of beer by, 120 ; varied nutrition of, 29.

Butyric fermentation, 121 ; literature of, 177 ; products of, 122 .

Cadaverine, 100; inhibitory percentage of, 82.

Cadeac and Bournay, on action of digestive fluids on bacteria, 174 .

Caesalpineae, occurrence of root-tubercies in, 91 .

Caesium, substitution of for potassium, 54 .

Calcium lactate, fermentation of, 122.

Cancer, supposed origin of, 39 .

Cane sugar, inversion of, I 10.

Capsules, occurrence of, 10. 
Carbohydrates, bacterial fermentation of, 116 seq.; function and occurrence of, 53 .

Carbolic acid, inhibitory percentage of, 82 ; lethal - of, 83 .

Carbon, sources of, 55 ; --compounds, nutritive importance of, 56,$57 ;-$ dioxide, circulation of, 107 , chap. XII ; inhibitory action of, 86 ; - monoxide, inhibitory action of, 86 .

Carbuncle, causes of, 145 ; production of by pus bacteria, 148 .

Caries of teeth, causes of, I 40.

Casein, in cheese, 119; in curds, II9.

Caseoglutin, occurrence of in cheese, 119 .

Cattle, anthrax in, $149,150$.

Cell-wall of bacteria, attachment of, 8 ; cellulose in, 9 ; chemical composition of, 9 ; permeability of, 8,9 .

Cellulose, fermentation of, 122,177 ; occurrence of in tubercie bacilli, 153 .

Certes, influence of high pressures on bacteria, 173 .

Chamberland, on attenuation, I70; on preventive inoculation, 184 .

Cheese, bacteria of, I I I, I 8 ; composition and ripening of, II 9 ; literature of, 177.

Chemical composition of bacteria, 52 .

Chemotaxis, 78 seq., chap. IX; literature of, 173 ; application of Weber's law to, 8o; character of morement and influence of concentration, 8I ; negative, 79 ; operation of in nature, 80.

Chilian saltpetre, origin of, 104 .

Chlorine, necessity of, 54 ; - water, lethal percentage of, 83,84 .

Chloroform, action of on ferments, 109.

Cholera, germs of, 155 ; - decomposition of fat by, 108; facultative parasitism of, 49; growth of in fluid media, 58; - in plate cultures, 59 ; - in milk, II7, I 8 ; literature of, I 82 ; polytrophism of, 29 ; production of indol by, IOI ; reproductive activity of, 17 ; transference of, 156 ; - serum, 167 .

Chromatin granules, occurrence of in diphtheria bacilli, 151 ; in Cladothrix, 7 , Fig. 5.

Chromatium, 66; distribution of pigment in, 12; C. Okenii, 65, Fig. 17.

Chromic acid, as fixing fluid, 6 .

Chromogenic bacteria, 12.

Chromoparous bacteria, 12, 13 .

Chromophorous bacteria, 12.

Chroococcus, shape of, 37 .

Cider, influence of bacteria on, I I 4 .

Cilia, abscission of, 15 ; anomalies in connexion with, 18 ; influence of external agencies on, I6; constancy and importance of, 31 ; forms of, 15, Fig. 8 ; influence of oxygen on, 61 ; use and staining of, 14 .
Ciliation, taxonomic importance of, 15.

Citric acid, production of by mould fungi, 1 IO.

Cladonia furcata, 93, Fig. 20.

Cladophora, evolution of oxygen from, 62, Fig. 16; C. fracta, process of celldivision in, 17 .

Cladothrix, 36 ; arthrospores of, 22 ; characters of, 34 ; occurrence of iron in, 70 ; sap-vacuoles in, 6 ; sliding growth of, I 8 ; sheaths of, 10; $C$. dichotoma, 3 , Fig. 2; chromatin granules of, 7 , Fig. 5 ; formation of swarm spores by, 25, Fig. 12 ; pleomorphy of, 24.

Classification of bacteria, 32, 33, 34; difficulty of, 30 ; features of, 30,31 .

Claudon and Morin, 178 .

Clostrideae, 33 .

Clostridtum, characters of, forms of, I21 ; C. butyricum, I1 I, Fig. 24, I21 ; formation of spores of, 20, Fig. I I ; germination of, $22 ; C$. Pasteurianum, characters of, 96 ; fixation of $\mathrm{N}$ by, 96 .

Coal gas, inhibitory action of, 86 .

Coccaceae, 32.

Cocci of suppuration, 147, I48, I49.

Coccidia, 4I.

Coccobacteria septica, 29.

Coccus, definition of, 2.

Cohn, 2 ; on $B$.termo, IOI ; on classification of bacteria, 29, 30, 3I I I 7 I ; on thermogenic bacteria, 63,172 ; on putrefactive bacteria, 175 ; on relation of temperature to bacteria, 173 ; on resistance to desiccation, 173 ; on species of bacteria, 170 ; on spores of, 170 .

Cohn and Mendelssohn, influence of electric currents on bacteria, I 72 .

Colloid silica media, 58 .

Colon bacillus, 154 .

Comma bacillus, I 56 ; shape of, 2 .

Concentration, influence of on bacteria, 9 .

Conn, on influence of bacteria on flavour of butter, 177 .

Contagium animatum, I59; -- vivum, 142.

Coppen Jones, on branching of tubercle bacilli, I 70 .

Coprinus, influence of light on, 72 .

Cornil and Babes, $\mathbf{1} 80$.

Corrosive sublimate, poisonous action of, 57.

Coryne bacterium, 27 ; C. diphtheriae, 150, $15 \mathrm{I}$.

Cow-pox, microbe of, 40.

Cramer, on composition of bacteria, 17 I.

Crenothrix, characters of, 34 ; sheaths of, Io; iron in, 70.

Culture, general principles of, 52 , chap. VI ; - media, 54, 55 ; - fluid, 56 ; growth in, 58; for phosphorescent bacteria, 63 ; - solid, use of, 57,58 ; plate, stab and streak, 58,59 ; influence of on per- 
centacre composition, 52; - of acidity and alkalinity of, $55,56,131$.

Cupric sulphate, inefficiency of as disinfectant, 84 ; lethal percentage of, $\delta_{3}$.

Curds, composition of, 119 ; influence of bacteria on, I 19.

Cyanin, inhibitory percentage of, 82 .

Cyanogen, as source of carbon, 57 .

Cyanophyceae and bacteria, relationship between, 37 .

Cytoryctes variolae, association of with cowpox, 40.

Czaplewski, on tubercle bacilli, I 8 I.

Davaine, on anthrax inoculation, $18 \mathrm{I}$.

Dawson, on efficacy of nitragin, 93.

De Bary, on arthrospores, 22, 170; on species in bacteria, 170 ; on systematic position of yeast, 178 .

Denitrifying bacteria, 176 .

Desiccation, influence of on maximal temperatures, 76 ; resistance of bacteria to, 19, 77, 144, 173; of spores to, 19, $44,45,128$.

Dextrane, occurrence of in slime bacteria, 53.

Diastase, hydrolytic action of, I09, I 31 .

Dieudonné, on cholera vibrio, 182.

Digestion, relation of bacteria to, 141 .

Digestive fluids, action of on bacteria, 87 .

Dissacharides, inversion of, $13 \mathrm{I}$.

Diseases, relation of bacteria to, 137 , chap. XV.

Disinfection, $84-87,173$.

Dissociation, influence of on toxicity, $\delta_{5}$, 174.

Distilled water, resistance of spores to, 84 .

Distribution of bacteria, 44 .

Diphtheria, cause of, 150; bacilli of, 151, 152 ; growth of in milk, 117,118 ; involution forms of, 27, Fig. I4; occurrence of Streplococcus pyogenes in, 148 ; - toxin, immunity to, 163 .

Diplococcus pneumoniae, properties of, 149 .

Division, planes of, 18 , 19 .

Drepanidium ranae, parasitism of, $4 \mathrm{I}$.

Dresera, bacteria on leaf of, 138.

Duclaux, on biological chemistry, 176 ; on milk, 176 .

Dulcite, fermentation of, II4; nutritive value of, 57 .

Dunbar, on diagnosis of cholera vibrios, I 84 .

Dysentery, supposed cause of, 40 .

D) ziergowski and Rekowski, on nutrition of diphtheria bacilli, I 82 .

Ecballium elaterinum, plasmolysis of, 5 .

Effront, 177; hydrofluoric method of, I20.

Ehrenberg, on systematic position of bacteria, $\mathbf{I}$.

Ehrenfest, on B. coli, I 82 .
Ehrlich, on diphtheria serum, 184; on immunity, 183 .

Fidam, on resistance to desiccation, 173.

Eleagmus, root tubercles of, 89.

Electric currents, germicidal action of, 72 ; movements induced by, 73 .

Elements, essential for bacteria, 54 .

Emmenthaler cheese, composition of, 119.

Endospores, 20, Fig. II, 2 I.

Engelmann, bacterium method of, 61, 62, Fig. 16, 172; on green bacteria, 169; on purple bacteria, 68,172 .

Ensilage, I 20.

Enzymes, 176, 178; definition of, 108; action of, 110 ; theory of, 134 .

Epithelium, impenetrability of by bacteria, $142,145$.

Eriksson, on breeds of Puicinia, 93 .

Ernst, 180.

Erysipelas, aetiology of, $148,180$.

Erythrite, butyric fermentation of, $12 \mathrm{I}$.

Erythrobacteria, 66; photosynthesis of, 68 ; rays effective in, 68,69 .

Escherich, on diphtheria, I 81 ; on intestinal bacteria of infants, 176, I80; on serum therapeutics, 184.

Ether, action of on ferments, I09; lethal percentage of, 83 .

Ethyl alcohol, fermentation of, II2; production of by bacteria, II2, 114; by yeast, 132.

Ethylidene lactic acid, production of, i 16.

Eucarpous, 36.

Eurythermic, definition of, 74 .

Exouscues, yeast of, I 30.

Facultative anaerobes, $6 \mathrm{I}$.

Facultative parasites, 49 .

Faeces, bacteria in, $14 \mathrm{I}$.

Fat, decomposition of by bacteria, I08; - during ripening of cheese, 119; occurrence of in old cultures, 14 ; percentage of in bacteria, 52 .

Favus, cause of, 42.

Fechner, psycho-physical law of, so.

Fehleisen, on erysipelas, 180.

Fermentation, I08 ; literature of, I76, 179 ; biochemical explanation of, I 35 ; theories of, I33, I34, 135; technical uses of, 123, I24, I25; oxidatory, I1 ; - organisms, relation of to oxygen, I 35 ; - products, heat of combustion of, 135, i 36 .

Ferments, 108; action of, 109; organized, by-products of, IIO.

Fermi, on non-nitrogenous bacteria, 171 .

Ferro-bacteria, 69.

Fibrin, butyric fermentation of, $12 \mathrm{I}$.

Finger, Ghon and Schlagenhaufer, on biology of Gonococcus, 181.

Finkler and Prior, on cholera vibrios, 182. 
Fischer, on cilia of bacteria, I70; on classification of, I70, I7I ; on enzymes, 176 ; on phosphorescent bacteria, 172; on plankton bacteria, 172 .

Fischer and Lindner, on enzymes of yeast, 178.

Fission of bacteria, 16; rapidity of, 17 ; regular and irregular sequence of, 19.

Fixing of bacteria, 6 .

Flagellata, relationship of to bacteria, 38 .

Flagellum, taxonomic importance of, $3 \mathrm{I}$.

Flax, retting of, 123 .

Flexile filaments, I6.

Fligge, on decrease of virulence, $\mathrm{I}_{3} 3$; on micro-organisms, 169; - pathogenic, I7I ; on sterilization of milk, 177 .

Fodder, lactic fermentation of, 120.

Fodor, bacteric idal action of blood, 183 .

Formic acid, production of by bacteria, I I 4 .

Formic aldehyde, lethal percentage of, 83 .

Fossil bacteria, I61 ; literature of, I82.

Frank, on symbiosis, 174 ; F. and Kruger, on potato scale, 179 .

Fränkel, on pneumonia, 181 ; germ of, 149; on nutrition of bacteria, 171 .

Freudenreich, on bacteria in cheese and milk, I76; on kephir, 177.

Freund, occurrence of cellulose in tubercle bacilli, 9 .

Frog spawn bacterium, 124.

Fruits, causes of rotting of, 99 .

Fumaric acid, bacterial decomposition of, 115.

Fungi and bacteria, comparison between, 35,36 .

Fusel oil, produ tion of, 132.

Gabritschewsky, on chemotaxis of leu-ocytes, 173.

Gaftky, on typhoid fever, 182 .

Galvanotropism, 73 .

Ganghofner, on serum treatment of diphtheria, I 84 .

Garden motld, presence of bacteria in, 47 .

Garré, on aetiology of inflammation, I 80 ; on production of carbuncles, 148 .

Gärtner, on heredity of tuberculosis, $18 \mathbf{I}$.

Gases, toxicity of, $\$ 6$.

Gastric juice, action of on bacteria, 87,174 ; on cholera germs, 156.

Geotropism, absence of in bacteria, 73 .

Geppert, on disinfection, 173.

Gelatine media, 57; liquefaction of, 58 .

Germination of spores, 20, Fig. 11, 22 ; of yeast, 127 .

Gilbert and Dominici, on bacteria of intestine, 180.

Glabrificines, I84.

Glacier ice, occurrence of bacteria in, 46 .

Glanders germs, growth of in milk, 117,118 .

Globig, on thermophile bacteria, 173 .

Gloeocapsa, shape of, 37 .
Glucase, 178 .

Glycerine, chemotaxis of, 79 ; fermentation of, II4; nutritive value of, 57 ; production of by yeast, 132 ; resistance of spores to, 84 ; as source of $\mathrm{C}, 55$; influence of on assimilation of N, 56 .

Glycocol, Ioo.

Godlewski, on nitrate bacteria, 175 .

'Gommose bacillaire' of vine, 138.

Gonidia, 22.

Gonococci, 30, 49, I \&o, 143, Fig. 27 ; media for, 57 ; properties of, 148 .

Gonorrhoea, cause of, 148 ; - rheumatism, cause of, I49; literature of, I ío.

Gonnermann, on root-nodule bacteria, 174.

Gottstein and Schleich, 184 .

Gourd, min., max. and optimal temperatures for germination of, 74 .

Granulobacter, 30 ; G. lactobutyricus, II; $G$. saccharobutyricus, 121 .

Granulose, in bacteria, 13, 121, I39.

Gregarineae, 41.

Grimbert, on B. orthobutylicus, 177 .

Gruber, on glabrificines, 184 .

Gum arabic, butyric fermentation of, $12 \mathrm{I}$.

Gumprecht, on tetanus poison, 182 .

Günther, on Vibrio aquatilis, 182.

Haemamoeba, 4 o.

Haemopoeic organs, 161.

Haemosporidia, 41.

Halibacterium, 30.

Halogens, germicidal action of, 84 .

Hamburger, on action of gastric juice on bacteria, I 74 :

Hansen, on acetic bacteria, 112,176 ; influence of heat on sporulation, 129; on Proteus, 102; on putrefactive bacteria, 175 ; on yeast, $110,178$.

Haplobacteria, 2 ; ordinal rank of, 31 .

Haplobacterineae, 32.

Haplomycetes, $4 \mathrm{I}$.

Havannah tobacco, bacteria of, 124 .

Heat, evolution of from seeds, 62, from bacteria, 63 ; influence of on ferments, I09; - on virulence of anthrax bacilli, 28 ; production of by Micrococcus, 63; resistance of spores to, 128.

Heider, on Vibrio danubicus, 182.

Heim, on pathogenic bacteria of milk, butter, and cheese, 177.

Helfeld, on manure bacteria, 175 .

Hellriegel and Wilfahrt, on assimilation of free N, 91, by Leguminoseae, 174 .

Hemp, retting of, 123 .

Herpes, 36 ; cause of, 42 .

Hesse, on agar culture, 172 ; on bacteriological analysis of air, $17 \mathrm{I}$.

Hibernation of Eacteria, 75 .

Holocarpous, 36 .

Homococcaceae, 33 ; chalacters of, 32. 
Hoppe-Seyler, on fermentation of cellulose, 177 ; on oxygcn and micro-organisms, 175 .

Human body, bacteria in, 139.

Hiippe, on involution forms, 170 ; on lactic fermentation, 176 .

Hydrogen, inhibitory action of, 86 ; production of, 122.

Hydrolytic action of enzymes, Iog.

Hydrophobia, inoculation for, $\mathrm{I} 8_{4}$.

Hyphae, 36 .

Hyphomy'cetes, $4 \mathrm{I}$.

Immunity, acquired, $\mathrm{i} 63$; method of producing, 163,164 ; duration of, 164 ; hereditary, 165 ; literature of, 183,184 ; peculiarities of, 164 .

Incubation period, 158 .

Incubators, use of, 75 .

Indican, fermentation of, 124 .

Indigo, production of, $177 ;$ - fermentation, 177 .

Indigofira tinctoria, I24.

Indigoglucine, production of from indican, I 24.

Indol, 99, I00; absence of from cheese, I19; production of by chulera germs, 101, I 56 ; by bacteria, 98 ; - reaction, 155 .

Infection, I80; conditions for, I45; mode of, 1 44, 1 45; - thre..d, 94, Fig. 2 I.

Inhibitory coefficient, 82 .

Inoculation, principle of, 144 ; by insect stings, 145; methods, toxines, I63, attenuated cultures, 164 ; for small-pox, 168.

Intestine, bacteria of, I4I ; sterility of in new-born infants, 142.

Invertase, action of on cane sugar, IIo; properties of, I $3 \mathrm{I}$.

Involution forms, 26, 27; literature of, 170.

Iodine trichloride, influence of on virulence of diphtheria and tetanus bacilli, 29; inhibitory percentage of, 82 .

Iodececcus, presence of granulose in, 139.

Iodoform, lethal percentage of, 83 .

I ron, necessity of, 54 ; - bacteria, nutrition of, 69 ; literature of, $\mathbf{1} 72$.

Isobutyl alcohol, production of by yeast, I 32 .

Isobutyleneglycol, production of by yeast, 132.

Isolation of pathogenic bacteria, methods of, 143 .

Janowski, influence of light on bacteria, 172. Japan, nitrite bacteria of, 105 .

Java, nitrate bacteria of, 105 .

Jenner's vaccination, 168 .

Kappes, on composition of bacteria, 17 I.

Kaspareck and Kornauth, on infection of plants by anthrax, 179 .
Kephir, omposition of, 120 ; inversion of lactose by, 131 ; production and properties of, 119, 120.

Kitasato, on tetanus bacillus, 181 ; inoculation of, 181 ; poison of, 182 .

Klcchi (v.) on B. saccharobutyricus, 177 ; on ripening of chcese, 177 .

Klein, on influence of light on fungi, 172.

Klöcker and Schiöning, on Saccharomyce's, 178.

Kloster, definition of, 32.

Kobert, on intoxications, I 83 ; on ptomaines, 175.

lioch, on anthrax, 2, 169, 181 ; on Bacillus, 32 ; on $B$. anthracis, 149 ; on cholera, 155, 182; on disinfection, 173; on gelatine culture, 172 ; method of, 168 , 173 ; steamer of, 76 ; on tubercle bacilli, I 52, tingibility of, I8I ; on tuberculin, 160, 182; on tuberculosis, $18 \mathrm{I}$.

Koch and Hosaeus, on slime fungus of sugar, 178 .

Kornauth, on bacteria in plants, 179; on typhoid inoculation of mice, 182 .

Kossel, on diphtheria toxine, I 82 .

Kossowitsch, on assimilation of $\mathrm{N}$ by algae, 174.

Kramer,on economic importance of bacteria, 176 ; on mucilage production, 177 ; on ripening of cheese, 177 .

Krusse, on lysines, 184 .

Kuhn, on putrefactive bacteria, 175 .

Kühne, on tuberculin, I 82 .

Kurloff and Wagner, action of gastric juice on bacteria, 174 .

Kutscher, on phosphorescent bacteria, 172 .

Lactic acid, butyric fcrmentation of, I 15 , 122 ; occurrence of in cheese, 119 ; production of by bacteria, $115 ;-$ in rancid butter, I I 8 ; by Lenionostoc, I 24; in fermenting bread, 125; optical splitting of by bacteria, I 15 .

Lactic bacteria, non-liquefaction of gelatine by, 58 ; in kephir and in beer, 120.

Lactic fermentation, 116,117 ; literature of, 176.

Lafar, on acetic fermentation, I76; on acidity of yeast, 177 ; on spontaneous generation, 17I; on technical mycology, $168,176,177$.

Lamella (middle), solution of by bacteria, 123 .

Lamprocystis, 106; L. roseo-persicina, 65, Fig. 17.

Lathraea, bacteria in leaf-chambers of, 138.

I.averania, 40.

Lead acetate, lethal percentage of, 13 ; as disinfectant, $\& 4$.

Leguminosae, nitrogenous nutrition of, 89 ; partial parasitism of, 94,95 . 
Lehmann and Neumann, I69; on Bacterium and Bacillus, 35; on species of bacteria, I7I ; on fermentation of dough, I 78 .

Leichman, on 'mucilaginous' fermentation, 177.

Leipzig, nitrogen discharged by sewers of, IO3.

Leprosy, germ of, I 53.

Leptomitus, character of, $4 \mathrm{I}$.

leptothrix, deposition of iron in sheaths of, 69, 70; occurrence of in hot springs, 75 ; L. buccalis, 139; L. innominata, I39; L. ochracea, 69.

Lethal coefficients, 82 .

Leucin, 98,99 ; in cheese, 119 ; putrefactive decomposition of, ICO ; chemotaxis of, 173.

Leucocytes, ingestion of bacteria by, 161 , Fig. 29.

Leucocytosis, I6I ; literature of, I73.

Leuconostoc, arthrospores of, 23 ; secretion of mucilage by, 53 ; L. mesenteroides, capsules of, Io, F ig. 7 ; formation of chains by, 19; growth of in beet-juice, 124.

Leuwenhoek, discovery of bacteria by, I ; works of, I69.

Lewkowitsch, on production of amygdalic acid, 176.

Lichen fungi, parasitism of, 93, Fig. 20.

Liesenberg and Zopf, on L. mesenteroitles, 178 .

Life, origin of, 50 ; primitive character of, 51 .

Light, influence of on erythrobacteria and on pigment formation, 70 ; - on virulence of anthrax bacilli, 28 ; deleterious rays of. 71 ; literature of, 172 ; production of by bacteria, 63 ; influence of on spore-formation by, 72 .

Lindner, on technics of fermentation, 178 .

Lock-jaw, cause of, 150.

Locomotion, organs and rapidity of in bacteria, 14 .

Löffler, 2 ; on cilia of bacteria, 170 ; method of staining, 14 ; on diphtheria, 81,82 ; on diseases of mice, 155,182 ; on history of bacteria, 169 ; on microorganisms of water, I7 I.

Löffler and Abel, on typhoid immunization, I 82 .

Lophotricha, I 5 ; taxonomic importance of, $3 \mathrm{I}$.

Lübbert, biology of bacteria, I $\varepsilon$ o.

Luciferin, 64.

Ludwig, on phosphorescent bacteria, 172.

Lupinus, percentage of $\mathrm{N}$ in, 89 ; roottubercle of, $90 ;$ L. albus, bacteroids of, 27, Fig. 14;90, Fig. I9.

Lysines, 168, 184 .

Magnesium carbonate, action of nitrite bacteria on, 165.
Malarial fever, microbe of, 40.

Maltase, properties of, $13 \mathrm{I}$.

Mammalia, bacterial diseases of, $138,139$.

- Mangin, 179.

Mannite, fermentation of, II4; nutritive value of, 57 ; production of by bacteria, 123.

Marine bacteria, $63,64,65$.

Massart and Bordet, on chemotaxis of leucocytes, 173 .

Mastigopliora, parasitism of, 39 .

Mayers, on fermentation, 178 .

Mazé, I69; on fixation of $\mathrm{N}, 92,174$.

Melanin, occurrence of in malaria, 40.

Menge and Krönig, on bacteria of vagina, I So.

Mercuric chloride, inhibitory and poisonous percentages of, 82,83 .

Merismopoedia, 37 .

Messea, 170.

Metatrophic bacteria, 54, 55; - fungi, 35 ; definition of, 48,49 .

Methane, I00; - bacteria, 123.

Methylmercaptan, Ioo.

Methyl violet, as a disinfectant, 86 .

Metschnikoff, on immunity, $18_{3}$; on phagocytosis, 161,183 .

Miasma, 142.

Mice, anthrax in, 150.

Micrococcus, 33 ; M. agilis, 12 ; movement of, 14 ; M. gonorrhoeae, I43, Fig. 27 ; 151, Fig. 28; characters of, 148 ; forms of, I49. M. pyogenes, 148, 151 , Fig. 2S; M. tetragenus, 33 ; mode of division in, 19, Fig. 10; M. ureae, 102, Fig. 22 ; decomposition of urea by, 183 .

Migula, on Bacterium and Bacillus, 32; on classification of bacteria, 171 .

Milk, bacteria in, 117,118 ; changes induced by, 118 ; ropiness of, 118,123 ; butyric bacteria in, 122 ; - sugar, in curds, 119.

Miller, on bacteria of mouth, 180.

Mimoseae, root-tubercles of, 91 .

Miquel, on bacteriological analysis of air, I 71 ; on B. thermophilus, 173 ; on urea ferments, 175,179 .

Molisch, on iron in plants, 172.

Moller, 172.

Monas, monotrichous character of, 38 .

Monilia candida, 39 .

Monosaccharides, fermentability of, I3I.

Monotricha, 15.

Monotrophism, 29, 49.

Morphology of bacteria, p. I seq., Chap. I.

Mosquitoes, relation of to malaria, 40 .

Mould fungi, fixation of $\mathrm{N}$ by, 97 ; organic disintegration by, 136.

Mouth, bacteria of, I 39, 180 .

Movements of bacteria, 14, 16; influence of plasmolysis on, 9 ; taxonomic value of, $3 \mathrm{I}$. 
Mucigenous bacteria, I 5.

Mucilage, 53,123 ; cxcretion of, 10 ; in beetmolasses, 124 .

Mucor, parasitism of, 43 ; rotting of fruits by, 99 ; - yeast, I10, I30; M. colymbifer, M. rlizopodiformis, parasitism of, 43 .

Müller, I.

Nlummies, bacteria of, 140 .

Mïntz, on nitrification, 175 .

Mycelium, 36 .

Mycobactivium, 27 ; M. Auberculosis, I53.

Miycoprotein, 53 .

Myxomycetes, 36 .

Nägeli, 2, 29; on fermentation, I79; on involution forms, I70; on molecular movements, 169 ; on nutrition of bacteria, 56, I7I; on specics in, I70; theory of fermentation of, I 34 .

Neisser, on gonorrhoeal fungus, I 81 ; on penetration of intestine by bacteria, I $\delta$.

Nencki, on anaerobism, i 72 ; on isolation of mycoprotein, 53 ; on putrefaction, 175.

Nencki and Scheffer, on chemical composition of bacteria, 171 .

Neoplasm, supposed origin of, 39.

Nepenthes, bacteria in pitcher of, 138 .

Neuridine, 100.

Nicolaier, on tetanus, I $8 \mathrm{I}$.

Nitragin, preparation and uses of, 93.

Nitrate bacteria, 55, 105, 106.

Nitrate-reducing bacteria, 106.

Nitrates, as source of $\mathrm{N}, 55,88,94$.

Nitric oxide, inhibitory action of, 86 .

Nitrification, literature of, I 75.

Nitrifying bacteria, culture medium for, 54 , I04, I05, Fig. 23.

Nitrite bacteria, 105.

Nitrites, as source of $\mathrm{N}, 54$, production of, 104, 106.

Nitrobacter, 30, 105, Fig. 23, 106.

Nitrogen, 56 ; amount of discharged from sewers, 103; circulation of, 88, Chap. $\mathrm{X}, 98$, Chap. XI ; fixation of, 96 ; liberation of, $98,99,104$; influence of combination of on fermentation, I I 5 ; literature on assimilation of, 174 ; sources of, 55,88 ; supposed absence of from certain organisms, $5 \mathrm{I}$.

Nitrosococcus, 105 .

Nitroscmenas, 30 ; N. eurcpea, 105, Fig. 23. N. javanensis, 105, Fig. 23.

Nitrous oxide, inhibitory action of, 86 .

Nobbe and Hiltner, on breeds of roottubercle bacteria, 93 .

Nobbe, Hiltner, and Schmid, on roottubercle bacteria, 174 .

Nocard and Roux, on tubercle bacillus, I 8 I.

Nostoc, I 25.

Nuclei, absorption of dyes by, 7,8 .

Nutrition, 52, Chap. VI ; peculiaritics of,

FISCHER
47,48 ; in fungi, 38 ; var) ing (haracter of, 29 .

Nuttall, on animals and bacteria, I $\$ 3$.

Nuttall and Thierfelder, on life without bacteria, 180.

Oats, consumption of combined $\mathrm{N}$ by, $9 \mathrm{I}$.

Obermuiller, on tuberculous milk, I77.

Obligatory aerobes, 60; - anacrobes, 61 ; - metatrophes, 49 ; - saprophytes, 49 .

Oceanic ooze, bacteria in, 64 .

Oedema, malignant, cause of, I 50 ; omnipresence of germs of, 47.

Oenanthic ether, production of by yeast, 32 .

Oidium, 39; influence of on ripening of cheese, II9.

Olive oil, decomposition of by bacteria, I08.

Omelianski, on fermentation of cellulose, I 77.

Oospora, 4I.

Optical decompositions, II 5 ; - properties, relations of to nutrition and fermentation, II 5 .

Oscillaria, 37 ; O. temis, 36, Fig. 15.

Osmic acid, as fixing fluid, 6 .

Osmotic pressure, 5; in bacterial cells, 8.

Oxygen, influence of on alcoholic fermentation, 132,178 ; - on growth of yeast, I 33 ; - on ciliary movement in aerobes and anaerobes, 61 ; - on pigment formation, 61 ; - on putrefaction, 100 ; - on spore formation, 150 ; relation of to fermentative organisms, 135 .

Ozone, inhibitory action of, 86.

Pancreatic juice, action of on bacteria, 87 .

Papilionaceae, root-tubercles of, $9 \mathrm{I}$.

Paracasein, occurrence of in curds, II 9.

Parachromatophores, I 3 .

Paraoxyphenylacetic acid, Ioo.

Parasites, 47 ; bacterial, I 44.

Parasitism, influence of temperature on, 43 .

Paratrophic, 48, 49; - bacteria, 57 ; fungi, 36 .

Passet, on aetiology of Pneumonia, I 80.

Pasteur, 2 ; on anaerobiosis, 60, 133, 172 ; dictum of, I 34 ; on fermentation, I IO; influence of heat on anthrax, 29; on organized ferments, 108 ; on production of racemic acid, 176 ; on protective inoculation for rabies, I68, I 84 ; - for anthrax, I68; on silkworm disease, I 38 , I 80 ; on spontaneous generation, 171 ; studies on beer, I79; wine, 177 ; works of, 176 .

Pasteur, Chamberland, and Roux, on attenuation, 170. P. and Joubcrt, on fermentation of urine, 175 .

Pasteurization of wine, 75 .

I'athogenic bacteria, I 5 I, Fig. 28 ; isolation of, 143 ; culture and attenuation of, 144 ; mode of action of, 158,159 ; products 
of, 159,160 ; relation of to host, 146 ; varieties and races of, 147 .

Paul and Krönig, action of chemicals on bacteria, 173 .

Pea, butyric fermentation of, I2I ; fixation of $\mathrm{N}$ by, $9 \mathrm{I}$.

Pectin compounds, action of retting bacteria on, 123.

Pediococcus, 33 ; P.tetragenus, 19, Fig. 10.

Pellicles, formation of, 3 ; character of, 4 .

Penicillium, growth of on fruits, 99; $P$. glaucum, 3, Fig. 2 ; 36, Fig. I 5 ; influence of on ripening of cheese, II 9 .

Pentamethylendiamine, 100.

Pepsin, action of on proteids, I IO.

Peptone, chemotaxis of, 79; minimal amount for, 8I ; properties of, 99 ; as source of $\mathrm{N}$ and of $\mathrm{C}, 55$; - bacteria, 55.

Péré, on lactic fermentation, 176.

Perithecia, 42.

Peritricha, I5 ; taxonomic importance of, 3 I.

Permeability of bacteria, 8,9 .

Peters, on fermentation of dough, 178 .

Petruschky, on pathogenic Streptococci, I So.

Pettenkofer, on cliolera, 182.

Pettenkofer and Emmerich, on cholera germs, 155.

Pfeffer, on chemotaxis, 79, I73; minimal amount of peptone for, 81 ; on Weber's Law, I73; on symbiosis of Lichens, 95.

Pfeiffer, cholera serum reaction of, 166 ; on diagnosis of cholera Vibrio, $\mathrm{I} \$ 4$; on immunity, 155.

Pfeiffer and Proskauer, on cholera antitoxin, 184 .

Pflüger, on phosphorescent bacteria, 172.

Phagocytes, ingestion of bacteria by, 16I ; chemotropism of, 162 .

Phagocytosis, literature of, I $82, \mathrm{I} 83$.

Phenol, 99; action of on ferments, 109 ; on virulence of bacteria, 28 .

Phenylacetic acid, 99.

Phenylamido-propionic acid in cheese, I 19.

Phenylpropionic acid, 99.

Phisalix, on asporogenous anthrax, I70.

Phosphorescence, of bacteria, 63, 172 ; influence of oxygen on, 63 ; culture of, 63,64 .

Phosphuretted hydrogen, production of, 100.

Photobacterium, 30, 63.

Phototactic sensitiveness, 69 .

Phthisis, occurrence of Streptococcus pyogenes in, 148.

Pigments, of bacteria, 12 seq.; in milk, I 8 ; distribution of, $12, \mathrm{I}_{3}$; influence of medium on, 56 ; of oxygen on, 61 ; in yeasts, 128 .

Pilobolus, influence of light on formation of sporangia of, 72 .

Pinguicula, bacteria on leaf of, 138 .

Planococcus, 33.
Planosarcina, 33.

Plasmodium malariue, 40.

Plasmolysis, 6; of bacteria, 8, Fig. 6; influence of on movement, 9 .

Plate culture, 58.

Plectridiae, 33 .

Plectridium, 33 ; types of, 121 ; $P$. paludosum, III, Fig. 24 ; formation of spores of, 20, Fig. II. P. tetani, I5o.

Plectron, 32 ; of anthrax, 31 .

Pleogeny, 24, 29.

Pleomorphism, 274 ; literature of, 170 ; in haplo-bacteria, 25 .

Pleurococcus, 37.

Pneumococcus, I49; fermentative activity of, II 4 .

Pneumonia, cause of, I 49.

Poikilothermism of bacteria, 73 .

Poisons, chemotaxis of, 79,80 ; modification of action of, $\delta 1,82$; lethal and inhibitory percentages of, 82,83 .

Polar granules, 9.

Pollender, on anthrax in blood, 181 .

Polysaccharides, non-fermentability of by yeast, I3I.

Polytoma uzella, 38 .

Polytrophic bacteria, 29.

Polytrophism, 49.

Popoff, on fermentation of dough, I7 8 .

Potash, caustic, lethal percentage of, 83,84 .

Potassium salts, chemotaxis of, 79 ; nitrate as source of N, 55 ; - permanganate, lethal percentage of, 83,84 .

Potato, bacterial diseases of, 138 .

Prazmowski, on development of bacteria, I70; on involution forms, I70; on root-tubercle bacteria, 174 .

Predisposition, 167.

Pressure, influence of on bacteria, 73, I73.

Primitive organisms, theories of, 7 .

Propionic acid, production of by bacteria, I 14.

Propyl alcohol, production of by yeast, 132 .

Proskauer and Beck, on tubercle bacillus, I8I.

Proteids, percentage of in bacteria, 52; decomposition of, 99, 100.

Proteus, 30, 102; P. vulgaris, I01, 102, Fig. 22.

Protista, 35 ; place of in nature, 36 .

Prototrophic bacteria, 54 .

Prototrophism, 48, 49.

Protozoa, importance of in putrefaction, 136.

Pseudomonas, 32.

Pseudopodia, 40.

Psichohormizm, iron in, 70.

Psycho-physical law, So.

Ptomaines, importance of, 159 ; literature of, 175 ; production of, 100.

Ptomatropine, 100.

Puccinia, cultural varieties of, 93 .

Pulmonary phthisis, origin of, 152.

Purple bacteria, 172 . 
Pus-bacterial, 1+8, 149; - cocci, results of injection of, 145 .

Putrefaction, 101; influence of oxygen and proteids on, 100; of temperature and water on, 99 ; peculiarities of, 102, 103 ; liberation of $\mathrm{N}$ by, $10_{4}$; ultimate products of, 101; - in intestine, $1+1$.

l'utrefactive bacteria, 102, Fig. 22 ; literature of, 175 ; zymogenic properties of, 102.

Putrescine, roo.

Pyaemia, 145 ; causes of, 148.

Pykotanine, as disinfectant, 86.

Pyogenic diseases, 148.

Pyrenomycetes, disintegration of wood by, 136.

Quarter-evil of cattle, causes of, $120,150$.

Quinine, inhibitory percentage of, $8 \mathbf{2}$.

Rabies, inoculation for, 168; Pasteur's treatment of, 184.

Rabinowitsch, on thermophile bacteria, 173 .

Racemic acid, optical decomposition of by bacteria, 115 .

Radicles, basic and acid, chemotaxis of, 79 .

Ragi, symbiotic character of, 110.

Raphidia, 37.

Rathay, on gum-producing bacteria, 179.

Ray-fungus, parasitism of, 4I ; sporangia of, 42 .

Rayer, on anthrax bacilli in blood, 181 .

Red sulphur bacteria, nutrition of, 68 .

Rees, on yeasts, 178 .

Renault, on fossil bacteria, 183 .

Rennet, production of by bacteria, 117,118 .

Reproduction, of bacteria, by fission, 16 seq. ; rapidity of, 17 ; by spore formation, 19 seq.

Respiration, of bacteria, 6o ; intramolecular, 133.

Retting bacteria, 123; of flax, 177.

Rhinanthaceae, partial parasitism of, 96.

Rhizobium leguminosarum, 92.

Riedler, on leucocytosis, 173.

Ring-worm, cause of, 42 .

Röntgen rays, action of on bacteria, 73 .

Root-nodules, 89; intercellular spaces in, I74; literature of, 174 ; percentage of $\mathrm{N}$ in, 95; structure of, 90, Fig. 19; bacteria of, assimilation of $\mathrm{N}$ by, 89 , 92 ; - shape and properties of, 90, Fig. 19, 92, 93 ; artificial cultivation of, 92 ; penetration of, 94 ; growth and nutrition of, 95, Fig. $2 \mathrm{I}$.

Roquefort cheese, ripening of, 119.

Rosenbach, on infection of wounds, 180.

Rothenbach, on use of pure yeast, 177 .

Roux, on antitoxic scrums, $183,1 \varepsilon_{+}$; on asporogenous anthrax, 170 ; on bacteriolorical analysis of water, 171.

Roux and Martin, on diphtheria, 183 .
Roux and Yersin, on diplitheria, 181 ; preparation of toxin of, 182 .

Rubidium, chemotaxis of, 79; substitution of for potassium, 54 .

Russel, on nitrate bacteria of oceanic oo:e, 65.

Saccharomyces, determination of species in, 128; forms of, 126, 127, Fig. 25; nutrition of, 131 ; pathological properties of, 36 ; symbiosis of in kephir, 120 ; systematic position of, $130 ; S$. albicans, parasitism of, 39 ; $S$. cerevisice, races of, 111 ; sporulation of, I28; S. cllipsoidcus, II I ; sporulation of, $128 ;$ S. glutinis, 128 ; S.mycoderma, decomposition of alcohol by, 112 ; $S$. Pastcurianus, sporulation of, 128.

Saké, preparation of, $\mathrm{I} 10$.

Salicylate of sodium, inhibitory percentage of, 82 .

Salicylic acid, lethal percentage of, 83 ; action of on ferments, 109.

Saliva, action of on bacteria, 87 .

Saltpetre beds, 104.

Salt solution, influence of on toxicity of sublimate, 86.

Sanarelli, on water bacteria, 180.

Saprogenic bacteria, 29; putrefactive power of, 101 .

Saprophile bacteria, definition of, 49 ; properties of, 101 .

Saprophytes, 47.

Sarcina, 33; mode of division in, 19, Fig. 10; social aggregates of, $31 ; S$. ventriculi, 141 .

Sarcosporidia, +1 .

Sauerkraut, production of, 121.

Scherffel, on leaf scales of Lathraect, 180.

Schild, on intestinal bacteria of infants, 180.

Schizomycetes, definition of, 35 .

Schizophyta, definition of, 37 .

Schloesing and Laurent, on fixation of $\mathrm{N}$ by bacteria, $17 \%$.

Schlossberger, on mycoprotein in yeast, 53. Schorf of potato, 138.

Schreiber, spore formation in bacteria, 170.

Schroeter, on bacterial pigments, 169 .

Sclerothrix Kochii, 153.

Scytonemeae, relationship of to Cladothrix; 37.

Sea-water, percentage of bacteria in, 64 .

Selective power, 115 .

Selmi, on ptomaines, 175 .

Septicaemia, 145 ; causes of, 148 .

Sero-therapeutics, investigations in, 161 ; principles of, 144 ; literature of, 184 .

Serum, bactericidal influence of, 162 ; curative, $165 ;$ - for cholera, 167 ; - mode of production of, $164 ;$ - treatment, literature of, $18_{3}, 18_{4}$. 
Sheaths, occurrence of, Io; ferruginous modification of, II.

Silkworm, disease of, 138 .

Silver nitrate, inhibitory percentage of, $8 \mathbf{2}$; lethal, 83 .

Sinapis alba, non-fixation of $\mathrm{N}$ by, 89 .

Skatol, absence of from cheese, I19; production of, 98 ; properties of, 99.

Small-pox, vaccination for, 168.

Soda, caustic, inhibitory percentage of, 82 ; inefficiency of as disinfectant, 84 .

Sodium, chemotaxis of, 79; necessity of, 54 ; - chloride, inhibitory percentage of, $82 ;$ - resistance of spores to, 84 .

Sommaruga, on metabolism of yeast, 176 .

South America, nitrite bacteria of, 105.

Soy, preparation of, 110.

Specific characters, of bacteria, 24, 29; variations of due to environment, 25-28.

Spirillaceae, 34 .

Spirillum, I, 34 ; sap vacuoles of, 6 ; shape of, $2 ; S$. desulphuricans, reduction of sulphates by, 106; S. rubrum, 12; influence of $\mathrm{O}$ on pigmentation of, 6I ; S. sputigenum, I, Fig. I ; S. undula, 3, Fig. 2; 7, Fig. 5; cilia of, 15, Fig. 8 ; plasmolysis of, 8 , Fig. 6 ; polar granules of, 9 ; saprophile character of, 101 .

Spirochucte, 2, 34; S. dentium, I39, 140, Fig. 26 ; S. Obermateri, 3, Fig. 2.

Spirulina, shape of, 37 .

Spontaneous generation, 50 ; literature of, I 7 I ; - combustion, causes of, 63 .

Spores, of bacteria, 19 seq. ; shapes of, 20 , $2 \mathrm{I}$, Fig. I I ; germination of, 20, Fig. II, 22 ; influence of heat on, 128 ; influence of desiccation on, 76 ; non-penetration of plants by, 137 ; resistance of to poisons, 83,84 ; staining of, 21 ; literature of, I7O; ubiquitous distribution of, 50 ; vitality of, 22 ; of Saccharomyces, 127, Fig. 25.

Spore formation, causes of, 23 ; influence of heat on, I29, I50; of oxygen on, I 50.

Spore membrane, influence on vitality of spore, 76.

Sporozoa, parasitism of, $4 \mathrm{I}$.

Sporulation, taxonomic value of, $3 \mathrm{I}$.

Spree, bacteria of, 46 .

Sputum, influence of on action of poisons, 83.

Stab-culture, 58 ; diagnostic value of, 59.

Stahl, on trophotropism, 78, 173.

Staining of bacteria, 6,7 .

Staphylococcus, size of, 4 ; immutability of, 25 ; mode of division of, $19 ; S$. pyogenes albus, 148; $S$. pyogenes aureus, I5I, Fig. 28 ; characters of, 148 ; colour of, I2; S. pyogenes citreus, 148.

Starch, fermentation of, I2I.

Stenothermic, 74 .
Stereo-isomers, production of by bacteria, 115.

Sterilization, $5 \mathbf{I}$.

Stichococcus, 37.

Stomach, bacteria of, I40; influence of acidity of on, I4I.

Streak-culture, 59.

Streptococius, 33; growth of in fluid media, 58 ; non-liquefaction of gelatine by, 58 ; S. pyogenes, 151, Fig. 28 ; characters of, 148; chains of, 19, Fig. 10.

Streptothrix, taxonomic position of, $4 \mathrm{I}$; $S$. actinomyces, 41 ; supposed sporangia of, 42 .

Stutzer and Hartleb, on nitrifying fungi, 175 .

Sublimate, inhibitory percentage of, 82 ; lethal, 83 .

Succinic acid, Ioo; nutritive value of, 57 ; production of by bacteria, II 4 ; - in kephir, I20;-by yeast, I32.

Sugar, butyric fermentation of, 121 ; chemotactic attraction of, 79 ; influence of on fixation of $\mathrm{N}$; nutritive value of, 57 ; - as source of $C, 55$.

Sulphur, in bacteria, $14,65,66$.

Sulphur-bacteria, 65, Fig. I 7 ; literature of, 172 ; nutrition of, 66,67 ; respiration of, 68 ; saprophile character of, $10 \mathrm{I}$.

Sulphur dioxide, inhibitory action of, 86 .

Sulphuretted hydrogen, inhibitory action of, 86.

Sulphuric acid, lethal percentage of, $\delta_{3}$; inefficiency of as disinfectant, 84 .

Sunlight, germicidal action of, 71 .

Suppuration, character and causes of, I47, I 48.

Sycosis, causes of, 148 .

Symbiosis, 93; of bacteria and carnivorous plants, 35 .

Tartaric acid, nutritive value of, 57 .

Taxonomy, 24, Chap. III.

Teeth, bacterial decay of, 140 .

Temperature, influence of an alcoholic fermentation, 132; on cholera germs, 156 ; on growth of Leuconostoc, 124; on parasitism, $43 ;-$ on production of poison, 157 ; - of yeast spores, 128 ; - of bacterial spores, I29, I 50 ; - on toxicity, 86 ; on urase, 179 ; resistance of bacteria to changes of, 19 ; literature of, 173 ; high, germicidal action of, 75 ; resistance of spores to, 75 ; influence of on toxines, I60; on putrefaction, 99 ; low, resistance to, 75 ; maxima, diagnostic value of, I I 2 ; optimum for acetic fermentation, II 3 ; relation of bacteria to, 73-75.

Tertiary epoch, bacteria of, $16 \mathrm{I}$.

Tetanus, aetiology of, $\mathbf{I} \$ \mathbf{I}$; artificial immunity to, I64; cause of, 150 ; influence of antitoxins on, 165 ; poison of, 182 ; 
- bacilli, presence of in soil, 147 ; toxine, 160 .

Tetrumitus, ciliation of, $3 \mathrm{~S}$.

Thermogenic bacteria, $6 \hat{3}$.

Thermogenous bacteria, 172 .

Thermophilic bacteria, 74 ; literature of, 173 .

Thesium, partial parasitism of, 96 .

Thiobacteria, 65 .

Thiocystis, pigment in, 12.

Thiopertia, 66; division of, I9; systematic position of, 33 .

Thiospirillum, 66.

Thiolhrix, 34, 66; arthrospores of, 22.

Thrush, origin of, 39 .

Thymol, inhibitory percentage of, 82 ; lethal, $\delta_{3}$.

Tisclutkin, on bacterial digestion, I So.

Tissues, pathogenic bacteria of, 145 ; demonstration of in, $142,143$.

Tobacco, fermentation of, 124 .

Tilypothrix, 37.

Toxalbumines, 53, I60.

Toxic and antitoxic units, 166.

Toxicity, influence of mixed solutions on, 86 ; relationship of dissociation to, 85 .

Toxines, intracellular, I60 ; preparation and properties of, 159 ; poisonous character of, 160 ; toleration of, 165 ; literature of, I $\delta_{2}-\mathrm{I} \delta_{4}$.

Tradesiantia, cell-division in, 18 .

Traube, theory of fermentation, 134.

Traumatic infection, $\mathbf{1} 50$.

Trichobacteria, definition of, 2 ; ordinal rank of, $3 \mathrm{I}$.

Trichobacteriaceae, 34 .

Trichomonas intestinalis, $39 ;$ T. vaginalis, 39.

Trichophyton tonsurans, parasitism of, 42 .

Trimethylamine, 100.

Trophotropism, 78, 173 .

Tubercle, cause of, 152 ; germs of, 153;bacilli, growth of in milk, I I 7 ; involution forms of, 170 ; lethal percentages of different poisons for, 81,83 ; sources of, II 8 ; in sputum, I 43, Fig. 27 ; stenothermic character of, 74 ; vitality of, 144.

Tuberculin, composition and preparation of, 160 ; literature of, 182.

Tuberculomyces, 27, 153.

Tuberculosis, aetiology of, ISI ; influence of on milk, I I 8 ; transference of, 152.

Turgor, definition of, 5 .

Typhoid bacilli, 7, Fig. 5; decomposition of fat by, 108; growth of in milk, I17, 118 ; plasmolysis of, 8 , Fig. 6 ; polytrophism of, 29 ; suppuration due to, 147 ; - fever, cause of, 154 ; actiology of, $\mathbf{I} 8 \mathbf{I}$.

Tyrosin, 99 ; occurrence of in cheese, I19; production of by bacteria, $9 S$; putrefaction of, 100 .
Tyrothrix, in cheese, I 19; curdling of milk by, i i 8 .

Tyrotoxine, 100

Urase, 178 ; mode of action of, 135 .

Urea, fermentation of, 134 ; nutritive value of, 57 ; - bacteria, 103; literature of, 175

Urobacillus Schützenbergii, 179.

Ustilago, yeast of, I 30 ; U. carbo, resistancc of spores of to desiccation, 79 .

Vaccine lymph, I68; - microbe, 40.

Vacuoles in bacteria, 6; demonstration of, 7, Fig. 5 .

Vaillurd, on hereditary immunity, 183 .

Valerianic acid, $\mathbf{I} 00$.

Valcric acid, Ioo.

Van Laer, on alc holic fermentation, 177.

Van Tieghem, on Bic. amylobacter, 177 on fossil butyric bacteria, I $\delta 2$; on Leuconostoc mesenteroides, 178.

Vegetables, mucilaginous fermentation of, 123 ; souring of, 120.

Verworn, on Protista, 172.

Vibrio, 1, 102, Fig. 22; characters of, 34 ; shape of, $2 ; V$. albensis, phosphorescence of, $63 ; V$. berolinensis, pathogenicity of, I $56 ; V$. buccalis, I, Fig. 1 ; 139, 140, Fig. 26; $V$. cholerae, 3, Fig. 2 ; 7 , Fig. 5; 151, Fig. 28; cilia of, 15 . Fig. 8 ; culture of, 55,156 ; plasmolysis of, 8, Fig. 6; polar granules of, 9 ; sensitiveness of to acid, $56 ; V$. danubicus, pathogenicity of, I56; $V$. rugula, production of methane by, 121 .

Vibrion butyrique of Pasteur, I2 1.

Vicia villosa, bacteroids of, 27, Fig. I4; 90, Fig. 19.

Vine, bacterial diseases of, 138.

Vinegar, manufacture and fermentation of, I IO, I I I, I I 3 .

Virulence, definition of, 160.

Virus animatum, 142;-inanimum, I 59.

Vital air, 60.

Voges, on immunity to cholera, I 82.

Warington, on nitrification, 175 .

Water, percentages of in plants and animals, 52 ; presence of bacteria in, 45 ; bacteriological analysis of, 46 .

Watson-Cheyne, on infection, I8o; on Biac. anthracis, 179.

Watson-Cheyne and Cheshire, on Bacillus alvei, I 80.

Weber's Law, 80.

Wehmer, on Aspergillus yeast, 176; on decay of fruits, 175 .

Weichselbaum, on inflammation of lungs, is 1 .

Wcizmann, on ripening of cheese, 177.

Welter, influence of cold on bacteria, 173 . 
Went and Prinsen Geerligs, on Aspergillus yeast, 176.

Wertheim, on gonorrhoea, I8I.

Wheat, minimum, optimum, and maximum temperatures for germination of, 74 ; percentage of nitrogen in, 74 .

Wine, cause of sweetness of, 132 ; influence of bacteria on acidity of, 1 I 4 ; lactic fermentation of, 120; mucilaginousfermentation of, 123; - yeasts, races of, 129.

Winogradsky, on fixation of $\mathrm{N}$ by soil bacteria, 96, 174; on iron bacteria, 69, 142; nitrifying bacteria, 104, 175;plate-culture of, 105 ; retting bacteria, I77; sulphur bacteria, 65, 172 .

Wittlin, 173.

Wladimiroff, on antitoxin and tetanus poison, I $\varepsilon 4$.

Wolffhügel, on bacteriological analysis of water, $17 \mathrm{I}$.

IVollny, on humus, 175.
Woronin, on bacteroids of root-nodules, 90 ; on root-nodules, 174.

Wortmann, on pure yeasts, 178 .

Wounds, aseptic treatment of, 87 ; healing of in plants and animals, 145; nondangerous character of in plants, 138 .

Yanthoriat parietina, 93, Fig. 20.

Yeasts, 126 seq.; colonies and spores of, 127, Fig. 25 ; sterilization of, 120 ; influence of heat on sporulation of, 129 ; literature of, 178 ; wild varieties of, 131 ; variations in, 178 .

Yersin, on antiseptics, 173.

Zoogloea, formation of, 3 ; characters of, 4 . Zoogloea ramigera, 4, Fig. 3 .

Zopf, on life cycles of bacteria, 29; on pleomorphism in bacteria, 170.

Zymase, 179. 
OXFORD :

PRINTED AT THE CLARFNDON PRESS

BY HORACE HART, M.A.,

PRINTER TO THE UNIVERSITY 




